\title{
WestVirginiaUniversity
}

THE RESEARCH REPOSITORY @ WVU

Graduate Theses, Dissertations, and Problem Reports

2020

\section{The Civil War in Indian Territory, 1861-1865}

\author{
Zachery Cowsert \\ West Virginia University, zccowsert@mix.wvu.edu
}

Follow this and additional works at: https://researchrepository.wvu.edu/etd

Part of the United States History Commons

\section{Recommended Citation}

Cowsert, Zachery, "The Civil War in Indian Territory, 1861-1865" (2020). Graduate Theses, Dissertations, and Problem Reports. 7553.

https://researchrepository.wvu.edu/etd/7553

This Dissertation is protected by copyright and/or related rights. It has been brought to you by the The Research Repository @ WVU with permission from the rights-holder(s). You are free to use this Dissertation in any way that is permitted by the copyright and related rights legislation that applies to your use. For other uses you must obtain permission from the rights-holder(s) directly, unless additional rights are indicated by a Creative Commons license in the record and/ or on the work itself. This Dissertation has been accepted for inclusion in WVU Graduate Theses, Dissertations, and Problem Reports collection by an authorized administrator of The Research Repository @ WVU.

For more information, please contact researchrepository@mail.wvu.edu. 
The Civil War in Indian Territory, 1861-1865

\author{
Zachery C. Cowsert
}

Dissertation submitted

to the Eberly College of Arts and Sciences

at West Virginia University

in partial fulfillment of the requirements for the degree of

Ph.D. in

History

\author{
Jason Phillips, Ph.D., Chair \\ Brian Luskey, Ph.D. \\ Tyler Boulware, Ph.D. \\ Max Flomen, Ph.D. \\ Andrew Frank, Ph.D.
}

Department of History

\title{
Morgantown, West Virginia \\ 2020
}

Keywords: American Civil War, Native Americans, Indian Territory

Copyright 2020 Zachery C. Cowsert 


\section{ABSTRACT \\ The Civil War in Indian Territory, 1861-1865}

\section{Zachery C. Cowsert}

This dissertation explores the American Civil War in Indian Territory, with a particular focus on the experiences of the Five Tribes-Cherokee, Chickasaw, Choctaw, Creek, and Seminole. Throughout the dissertation, I offer three overarching arguments. First, the Civil War in Indian Territory was truly an Indian civil war, shaped by Native American politics and culture. Second, the Civil War constituted a forgotten but immensely destructive moment in Native history, the second great trauma endured by the Five Tribes in the $19^{\text {th }}$ century following westward removal. Third, the Civil War marked the violent crescendo of older Southeastern issues of removal and acculturation; by the end of the Civil War, new Western issues challenged Native American sovereignty, including land loss, railroads, allotment, territorial government, white settlement, and finally statehood.

The six chapters within this dissertation offer new interpretations of Civil War Indian Territory, and the first three chapters illuminate how Native Americans became mired in the American Civil War and came to take opposing sides in that conflict. Chapter 1 exposes the fraudulent nature of Confederate-Native negotiations in 1861, contending that political intimidation, vigilantism, and fraud were necessary to secure alliance between the Confederacy and the Five Tribes. Theses political tactics harkened back to the fraudulence of the removal era, and also indicate the weakness of Confederate nationalism in Indian Territory. Chapter 2 examines Native backlash to Confederate treaties, charting the mass mobilization and political and military resistance of Creek chief Opothleyahola and his followers in the autumn and winter of 1861. Opothleyahola's Rebellion constitutes a significant pan-Indian and slave rebellion against Confederate authority and sparked the beginning of years of destructive, intra-tribal civil war. Defeated and exiled to Kansas, the experiences and political power of "Loyal Indian" refugees are explored in Chapter 3. Despite their destitute condition, Native American refugees wielded a degree of political influence that ensured the United States military would attempt to liberate Indian Territory in 1862 and likewise be accompanied by Native Americans enlisted in the Indian Home Guard regiments.

The final three chapters document the wartime years between 1862-1865, wherein the Confederate States and United States vied for military control of the region to the detriment of its Native American denizens. Chapter 4 surveys the disastrous 1862 First Indian Expedition, a Federal invasion of Indian Territory that failed due to a difficult environment and poor leadership. Chapter 5 documents the failure of the Confederacy to live up to its treaty obligations, which left Confederate military forces at a decided material disadvantage in the crucial year of 1863. Confederate defeats at First Cabin Creek and Honey Springs permanently shifted the strategic situation in the United States' favor. Chapter 6 highlights how the war's final years devolved into an increasingly racialized struggle played out in raids and guerrilla warfare, worsening the refugee crisis and undermining civil society.

The conclusion illuminates how the Civil War undermined Native American sovereignty and left them vulnerable to Federal encroachment and westward expansion in the Reconstruction era. 


\section{Acknowledgements}

I am filled with warmth and gratitude for all the mentors, colleagues, friends, and family who guided me through graduate school and helped me with this dissertation. I must begin with sincere thanks to my advisor Dr. Jason Phillips. His thoughtful, sweeping feedback always broadened my horizons. More importantly, his office door was always open, and he provided support whenever I lost my way or felt overburdened by graduate school. I'm profoundly grateful to have him as a mentor. Dr. Brian Luskey encouraged me that I had something important to say and helped me forge stronger historiographical connections. Drs. Tyler Boulware, Max Flomen, and Andrew Frank sharpened my understanding of Native American history and offered important thoughts on how to "indigenize" my project moving forward. My committee's suggestions only made this project stronger, and any errors are my own. While countless archivists and librarians aided me, I'd like to especially thanks the staffs of West Virginia University, Gilcrease Museum and Library, and the Texas Heritage Museum.

I want to joyfully thank those who journeyed alongside me in graduate school, whom I affectionally call the "Woodburn Club"-Nerissa Aksamit, Alex Burns, Katy Ferrari, Luke Gramith, Tyler Krahe, John Martin McMillan, Justin Power, Marc Sanko, Cole Volman, Jack Weaver, Chuck Welsko, and many more. I couldn't have done it without you all.

To my mother Erin, I thank you for being the positive voice in my head urging me to success. To my father Rick, thanks for the camping trips and battlefield visits of my youth, which are the origins of this project. To my sister Alex, thanks being a role model to your big brother. And finally, to my wife Jeridan, I can only offer my deepest thanks and love. You are my companion and my anchor, and you surely deserve a history degree of your own for your ceaseless support and patience along the way. 
"We Are Choosing in What Way We Shall Die:" Factionalism and Fraud in Confederate-Native Diplomacy, 1861

Chapter II

“Now the Wolf Has Come:" Opothleyahola's Rebellion, 1861

Chapter III

"These Indians Say They Are Not Whipped Yet":

The Kansas Refugee Crisis and the Political Origins of the First Indian Expedition

Chapter IV

"Sweating, Choking, Broiling":

Environment, Leadership, and the Failure of the First Indian Expedition

Chapter V

"The Indians Are Not Cared For":

Cabin Creek, Honey Springs, and the Failure of the

Confederate-Indian Alliances

Chapter VI

"The Evils of Disunion, Discord, and War": Raids, Refugees, and Homefront, 1864-1865

Conclusion

"The Ruthless White Man Demanded It": The Postbellum Era 


\section{Introduction}

Ten year old Smaddie Pidgeon, a young Creek girl, stood on a hilltop in the winter wind and looked back on the chaotic scene below her. Her experiences that evening stayed with her throughout her life, and years later she related the scene to her son. Her party of Native refugees was "overtaken and had refuge on a hill while groups of men had stopped along the way to check the rear attackers." As twilight set in, Smaddie watched the panicky fight unfold below, which "seemed to be like the flicker of fireflies, with report of guns heard and flashed here and there the shooting." Smaddie and her party escaped her attackers that evening, and they made their way from that hilltop in northeast Indian Territory to Union Kansas through the harsh winter of $1861-1862 .^{1}$

The Confederate troopers attacking Creek and Seminole refugees like Smaddie's party that winter included white Southerners from Texas and Arkansas, men in regiments like the $2^{\text {nd }}$ Arkansas Mounted Rifles and $3^{\text {rd }}$ Texas Cavalry. Yet also among the Rebel ranks were the $1^{\text {st }}$ Creek Regiment, the $1^{\text {st }}$ Choctaw and Chickasaw Mounted Rifles, and the $1^{\text {st }}$ Seminole Battalion. Less than a year into the conflict, the Civil War in Indian Territory already pitted Creeks against Creeks and Seminoles against Seminoles, tearing Native Americans apart into their own brutal, intra-tribal civil wars. And, as Smaddie Pidgeon's memories attest, the war in Indian Territory pulled civilians into a vortex of violence, fear, and destruction from its opening moments.

In 1861, as dark clouds of secession and civil strife gathered on the horizon, Indian Territory was home to the Five Tribes: Cherokee, Chickasaw, Choctaw, Creek, and Seminole. After centuries living in their ancestral homelands in the American Southeast, these tribes

\footnotetext{
${ }^{1}$ Interview with Jackman Pidgeon, February 21, 1938, Indian Pioneer Papers, WHC, OU.
} 
endured the tragedy of forcible removal westward by the United States in the 1830s and 1840s, the Cherokee most infamously via the Trail of Tears. Suffering immense casualties on their journey west, they were given new lands in Indian Territory — an entity carved from Arkansas Territory in the 1820 s whose borders nearly align with the modern state of Oklahoma.

In this unfamiliar territory, the Five Tribes found new homelands. The Cherokees inhabited the northeastern corner of the territory, a region of gently rolling hills flowing west from the Ozark and Boston Mountains. The Arkansas River bisected Indian Territory running east towards the Mississippi, and along its northern tributaries could be found Cherokee farms and towns, including the national capital at Tahlequah. Further west, Creek Nation encompassed central Indian Territory amid the Cimarron and North Canadian Rivers, where the rolling hills gave way to mild, open prairies. In the 1840 s, following the conclusion of the long-fought Second Seminole War, several thousand Seminoles settled in western Creek lands and were granted nationhood in 1856. The Choctaws and Chickasaws inhabited southern Indian Territory, where they benefited from the rich soil of both the Arkansas and Red River Valleys, though the Ouachita Mountains protruded west out of southern Arkansas. As with the Seminoles, the Chickasaws gained separate nationhood later in 1855 . By 1860 , nearly 50,000 members of the Five Tribes inhabited the eastern half of Indian Territory. The Cherokee, Choctaw, and Creek Nations all boasted similar populations of approximately 13-14,000. The Choctaws numbered just over 4,000 and the Seminoles barely mustered 2,000. ${ }^{2}$

As the title of "nation" suggests, these tribes constituted semi-sovereign states. Although bound by treaties to the United States, they exercised a wide degree of autonomy over internal affairs. The Five Tribes enjoyed civil governments replete with constitutions, legislatures, and

\footnotetext{
${ }^{2}$ Michael F. Doran, "Population Statistics of Nineteenth-Century Indian Territory," Chronicles of Oklahoma 53:4 (1975), 501.
} 
principal chiefs. They boasted judicial systems and police forces. Whites were only allowed to trade or settle within Indian Territory with tribal permission (just over 2,000 lived in Indian Territory at the start of the Civil War). Missionaries preached Christianity and offered rudimentary education, and newspapers like the Choctaw and Chickasaw Intelligencer provided news from abroad. While most Indians engaged in subsistence agriculture, a wealthier class utilized enslaved labor to build prosperous plantations. Although Five Tribes maintained a population of over 8,000 enslaved blacks prior to the outbreak of the Civil War, the enslaved population were concentrated in the hands of a tiny minority (only $2.3 \%$ of Indians owned slaves). As their embrace of slavery suggests, Native Americans fostered economic and social ties with neighboring Arkansas and Texas. ${ }^{3}$

While the decades immediately prior to the Civil War are often depicted as a brief golden era for the Five Tribes, political and cultural schisms lurked under the surface. Acculturated, wealthy, slave-owning Native Americans wielded immense influence on tribal governments. These elites - men such as Cherokees Stand Watie, Choctaws Peter Pitchlynn and Robert M. Jones, and Creeks brothers Daniel and Chilly McIntosh—were often of mixed ancestry (usually phrased as "mixed-blood" in contemporary sources) and carried two identities, envisioning themselves as both Native Americans and as Southerners. They embraced education, Christianity, chattel slavery, plantation agriculture, and other American cultural and social trappings. Moreover, these elites were often the same individuals who espoused the necessity of removal a generation prior and who signed the fraudulent removal treaties of the $1820 \mathrm{~s}$ and 1830s.

\footnotetext{
${ }^{3}$ Michael F. Doran, "Negro Slaves of the Five Civilized Tribes," Annals of the Association of American Geographers 68:3 (Sept., 1978), 347.
} 
Yet these elites constituted only a minority of tribal populations. Although centuries of acculturation had indelibly shaped the lives of nearly every member of the Five Tribes, many natives continued to retain elements of their traditional indigenous lifestyles: they practiced syncretic religion, dressed in traditional Indian garb, spoke in their native tongue, and managed humble homesteads. For these Native Americans, acculturation must be contained, else their way of life might be lost. Their loyalties lay with those who championed and protected their lifestyles, men like Cherokee Chief John Ross and Creek leader Opothleyahola. They had fiercely opposed removal westward, and they harbored deep suspicions of their wealthy brethren who had signed the removal treaties and sought to forge stronger ties with white America.

These internal factions - the acculturated elites and traditionalist masses—profoundly shaped Native Americans' decision-making and experiences during the Civil War. ${ }^{4}$ While slaveholding elites sought social status and material protection in the Confederacy, traditionalist Indians initially balked at the prospect of war and when pressed, preferred instead to fight against this vision of acculturation by remaining loyal to the United States. In short, the American Civil War in Indian Territory was an Indian Civil War, waged by Natives over differing Native visions of the future within their own Native nations.

${ }^{4}$ Scholars have not coalesced around a set of terms to describe the cultural divisions within the Five Tribes. Early scholars often took "mixed-blood" and "full-blood" terms at face value, suggesting that race explained Native Americans cultural attitudes and decision-making. More recently, Theda Perdue and others have explicitly rejected this idea, warning that "we have privileged whiteness, and as a result, we have underestimated the power and persistence of the culture into which they ["mixed blood"] Indians were born and chose to live." Scholars have implemented other terms: conservative, progressive, mestizo, mixed-ancestry, etc. to label these cultural and ancestral divides.

I have utilized the terms traditionalist and acculturated in this dissertation, which focus on cultural attitudes rather than race. I also hope these terms avoid positive or negative connotations (which I believe conservative and progressive can suggest). These terms are not perfect. By 1860, acculturation had taken deep root among the Five Tribes. Even the most "traditionalist" Indians farmed, utilized tools, firearms, and cloth, knew something of Christianity....in short, these societies had already experienced centuries of irreversible acculturation. Yet a spectrum of acculturation remained, and in particular, differing views on the futures of these tribes-more tightly woven to American and Southern society or placing limits on American influence to preserve Natives lifestyles - existed. I hope these terms (traditionalist and acculturated) address that spectrum, despite their limitations. Theda Perdue, Mixed Blood Indians: Racial Construction in the Early South (Athens: University of Georgia Press, 2003), 68-69. 
Despite significant support for neutrality and peaceful status quo under existing Federal treaties, Native elite and regional Confederates waged a successful and fraudulent political campaign to pull the Five Tribes into Confederate orbit and the Civil War. Over the course of four years, that conflict proved violent and destructive to Indian Territory and its inhabitants. The Confederacy secured Indian alliances with grand promises of material aid and reinforcements; in reality, the Confederacy's paltry assistance left its military forces in Indian Territory, including Confederate Indians, unable to halt Federal advances into the region. Yet the United States never prioritized Indian Territory either, invading the region several times with mixed results, gaining footholds but never providing true security. Neither the Confederate or United States possessed the means or will to fully control Indian Territory. The result was the worst possible outcome: a seemingly endless series of invasions and retreats, raids and guerrilla warfare, banditry and abandoned homes, and an ever-growing refugee crisis.

When the war finally came to an end, much of Indian Territory—especially Cherokee, Creek, and Seminole Nations—-lay in ruins. Farms ransacked and burned, fields run fallow, livestock long confiscated, and towns desolately empty. Nearly three-fifths of the Territory's Native population were destitute refugees, clinging to Federal outposts or crowding into Confederate refugee camps for survival. And many didn't survive. Thousands of Cherokees, Chickasaws, Choctaws, Creeks, and Seminoles perished during the Civil War, though the final terrible tally will likely never be known. Among the Cherokees, nearly one-third of the population perished, and nearly a quarter of Creeks died during the war. The Civil War proved to be the second great trial of the Five Tribes in the $19^{\text {th }}$ century, eclipsed only by the horrors of westward removal itself. Yet this terrible saga remains obscured in the shadow of the larger American Civil War and is non-existent in public memory. 
Occurring years after westward removal and overshadowed by the grandeur and scale of the Civil War east of the Mississippi, the Indian Civil War in Indian Territory remains an obscure corner of history, overlooked by scholars and buffs alike. With a few exceptions, only in the past few years have scholars begun to seriously explore the war in Indian Territory and the experiences of its participants. Yet a detailed history of the politics and military affairs of wartime Indian Territory remains to written. Over the course of six chapters, I hope to fill that historiographical lacuna by a carefully examining how and why Native Americans were pulled into the Civil War, how Confederate alliances devolved into Indian civil war, both the Confederacy's and United States' attempt to exert military control over the region, and finally how the war impacted Native American civilians and communities. ${ }^{5}$

\footnotetext{
${ }^{5}$ Wiley Britton and Annie Heloise Abel pioneered the first serious historical accounts of the Civil War in Indian Territory. Wiley Britton's two volume Civil War on the Border (1890-1904), Memoirs of the Rebellion on the Border, 1863 (1882) and The Union Indian Brigade in the Civil War (1922) offer narrative accounts of the war in the region. They are also autobiographical, as Britton served in the $6^{\text {th }}$ Kansas Cavalry in Indian Territory for much of the war. Annie Heloise Abel wrote a three volume history of Native Americans in the Civil War: The American Indian as Slaveholder and Secessionist (1915), The American Indian in the Civil War, 1862-1865 (1919), and The American Indian under Reconstruction (1925). Though a century old, Abel's work remains the most exhaustive treatment of Civil War Indian Territory.

Although local historians continued to explore Civil War Indian Territory in the early/mid-20 $0^{\text {th }}$ century (often publishing in the Chronicles of Oklahoma), a long gap occurred before another book length treatment emerged. Lary and Donald Rampp produced The Civil War in the Indian Territory (1975), focused on military affairs in the region. They draw heavily from published sources, and their account of military affairs is succinct but uneven. W. Craig Gaines' The Confederate Cherokees: John Drew's Regiment of Mounted Rifles (1989) marks the beginning of a modern wave of scholarship on the Civil War in Indian Territory. Gaines utilized Drew's regiment as a window into fractious Cherokee politics in the war's early years. Benton and Christine White's Now the Wolf Has Come: The Creek Nation in the Civil War (1996) tells a compelling tale but adopts a problematic first-person narrative that blurs the lines between scholarship and storytelling. Clarissa Confer's The Cherokee Nation in the Civil War (2007) offers a short overview of Cherokee participation in the war, paying especial attention to civilian suffering and homefront. Mark Lause explores the radical abolitionist Kansans who shaped the Indian expeditions into the region in Race and Radicalism in the Union Army (2009). Mary Jane Warde's When the Wolf Came: The Civil War and the Indian Territory (2015) provides the first extensive, scholarly overview of Civil War Indian Territory in a century. Although her archival source base is limited, Warde weaves a narrative of wartime Indian Territory that focuses on the social and cultural implications of the war and makes connections to wider Oklahoma history. This dissertation seeks to complement her work by providing a detailed history of political and military events, as well as the experiences of wartime refugees. M. Jane Johansson's Albert C. Ellithorpe, the First Indian Home Guards, and the Civil War on the Trans-Mississippi Frontier (2016) provides a hybrid biography, regimental history, and primary source collection to shed light on Union Indian participation in the war.
} 
Chapter 1 explores the forging of alliances between the Fives Tribes and the Confederate States of America. In the spring of 1861, faced with an existential rebellion and limited resources, the United States withdrew its military forces from Indian Territory. The withdrawal of the United States from the region created a power vacuum, leaving Native Americans to fend for themselves. Although many Natives desired to remain neutral in the coming "white man's war," wealthy, slaveholding Indian elites believed their futures and property were best secured within the Confederacy. Neighboring white Confederates exploited these internal rifts, engaging in military occupation, vigilantism, political intimidation, and outright fraud to secure treaties of alliance with the Five Tribes. These fraudulent treaties, reminiscent of the deceitful removal treaties of an earlier era, provided an unstable foundation for the Confederate-Indian alliances and ultimately provoked Native resistance.

Moreover, the Confederacy's deceitful political tactics and Native reluctance to alliances attest to the Confederacy's inability to instill a deep sense of nationalism or loyalty among the entirety of the Indian population. If, as Stephanie McCurry has argued, the Confederacy was "a republic of white men, defined by slavery and the political exclusion of the mass of Southern people," many Native Americans rightfully questioned their place within that nation. While the Confederacy struggled informally to bring women, enslaved African-Americans, and nonslaveholders into line with their nation-building project, it made explicit promises to the Five Tribes via signed treaties. These obligations would prove difficult to fulfill. ${ }^{6}$

\footnotetext{
${ }^{6}$ Stephanie McCurry, Confederate Reckoning: Power and Politics in the Civil War South (Cambridge, MA: Harvard University Press, 2010), 2. McCurry's Confederate Reckoning argues the Confederacy's “profoundly narrow and mistaken vision of what nation making, war, and history required" contributed to disillusionment and dissent among Southern women and African-Americans during the war. McCurry is not the first scholar to explore the limitations (or outright failure) of Confederate nationalism. Paul Escott's After Secession: Jefferson Davis and the Failure of Confederate Nationalism highlights the Confederate government's unwillingness to address the
} 
Rather than submit to Confederate treaties, however, a large number of Creeks and Seminoles, along with smaller parties from other tribes and hundreds of African-American runaway slaves, mobilized and revolted in the autumn and winter of 1861. Chapter 2 navigates Opothleyahola's Rebellion, named after its venerable Creek leader. ${ }^{7}$ This anti-Confederate Indian rebellion represented the backlash to the fraudulent diplomacy between tribal governments and the Confederate States. Comprised of thousands of Native Americans and African-Americans, Opothleyahola's Rebellion constituted a major pan-Indian rebellion against white politics and a significant slave rebellion. This alliance between Native tribes and runaway slaves threatened Confederate control of the Territory and sparked fear among pro-Confederate tribal governments. Unwilling to let the challenge go unanswered, the Confederacy responded with military force in the winter of 1861 . Just as the Confederacy faced internal dissent among Southern Unionists, enslaved African-Americans, dependent white Southern women, and others, the Confederacy confronted Native resistance on its frontier. ${ }^{8}$

wartime plight of its everyday citizens, fostering political apathy toward the Confederate project. Paul Quigley advances another narrative, arguing that emotions - wartime loss and suffering — were what attached Southerners to the Confederate cause, rather than any deep ideological attachment to the Confederacy. Collectively, this scholarship explores the severe limitations of the Confederacy's efforts to instill nationalism among its citizens. In Indian Territory, the Confederacy's murky political tactics similarly failed to persuade many Native Americans the Confederate cause was worthy of support. Paul D. Escott, After Secession: Jefferson Davis and the Failure of Confederate Nationalism (Baton Rouge: Louisiana State University Press, 1977); Paul Quigley, Shifting Grounds: Nationalism and the American South, 1848-1865 (New York: Oxford University Press, 2012).

${ }^{7}$ I have chosen the word rebellion to indicate these Indians' resistance to both the pro-Confederate tribal governments (which they believed to be illegal) and to the Confederacy itself. While the Confederate-Creek treaty proved fraudulent, the pro-Confederate Creek faction and the CSA held de facto control of much of the Nation. Hence, dissident Creeks, Seminoles, blacks, and others were rebelling against the de facto authority in the region. Opothleyahola's name is indelibly linked to the rebellion, both among its participants and later historians, and he was its leader throughout.

${ }^{8}$ The Confederacy resorted to political maneuvering to ensure secession elsewhere, and throughout the war required force to quell internal dissent. Stephanie McCurry's Confederate Reckoning calls the secession movement "a long political season of fear mongering, coercion, and violence," and her work exposes how politically precarious pro-Confederate slaveholders' political power proved to be, even in the Deep South (most notably in Georgia). As she notes, "nowhere in the Lower South outside of South Carolina were ordinances of secession passed unanimously." The Confederacy subsequently failed to account the political agency of white Southern women, who demanded entitlements from the strained Confederate states, and enslaved black who engaged "in an array of insurrectionary activities calculated to destroy the institution of slavery, their masters' power, and the prospects of the C.S.A. as a proslavery nation." McCurry's arguments recall Thomas Emory's earlier The Confederacy as a 
Not simply a prelude to the war in Indian Territory, the rebellion constituted a significant political and military event in its own right. Opothleyahola's Rebellion plunged the Territory into intra-tribal civil war, pitting Creeks against Creeks, Seminoles against Seminoles, and Cherokees against Cherokees. It also constituted perhaps the largest slave rebellion in the Civil War. It brought "hard war" to Indian Territory, played out in a brutal winter campaign in November and December. Opothleyahola's forces were finally defeated and routed at the Battle of Chustenahlah and subsequently fled to Kansas amid the snows and winds of a bitter winter. In the final days of the campaign, Confederate forces targeted civilians like Smaddie Pigeon, hinting at the brutality of the war to come.

Chapter 3 surveys the experiences of the nearly 7,000 Native Americans refugees who survived the winter and spring of 1861-1862 in Kansas. Exiled from their homes in Indian Territory, Native Americans struggled to survive the ravages of disease, inclement weather, and shortages of provisions and shelter. Despite their destitute condition, however, Native refugees were not powerless. Just as African-American runaway slaves across the South forced the United States to embrace emancipation, Native American refugees likewise reshaped Federal military policy by forcing the U.S. to finally intervene military in Indian Territory. Working in conjunction with ambitious Kansas politicians and military officers, Native Americans and local white officials finally secured permission for an Indian Expedition to liberate Indian Territory and allow the "Loyal Indian" refugees to return home. Furthermore, Native Americans secured

Revolutionary Experience, wherein he points to the "class conflict, riots, strikes, and disloyalty to the point of armed resistance" that beset the wartime Confederacy. McCurry, Confederate Reckoning, 118; Thomas M. Emory, The Confederacy as a Revolutionary Experience (1971, repr., Columbia: University of South Carolina Press, 1991), 117. 
the right to participation in the expedition through the formation of the Indian Home Guard regiments. ${ }^{9}$

The 1862 Indian Expedition, comprised of Native Americans, Kansans, and Midwesterners, was envisioned as a triumphant return to Indian Territory for both the United States and the Loyal Indians. Instead, it proved a listless disaster. Chapter 4 examines how a military campaign that began with such promise ended in mutiny and humiliation. Inexperienced Union officers_-Kansan political appointees — proved unable to overcome serious logistical and strategic challenges imposed by Indian Territory. Enduring one of the hottest summers in the region's history, Union soldiers suffered from limited access to clean water and scant provisions. Although equally inept Confederate officers failed to mount meaningful resistance to the invasion, Union leaders jumped at threats both real and imagined. Unable to secure a decisive battlefield confrontation, short on provisions and long on alcohol, and seeing illusory foes on their flanks and rear, the expedition ended in mutiny and retreat.

While the Indian Expedition failed to secure the liberation of Indian Territory from Confederate control, it succeeded in sowing further discord and misery among the Territory's inhabitants. Faced with the return of the United States army, the Cherokee Nation split into two

\footnotetext{
${ }^{9}$ The ability of Native American refugees to shape Federal military policy resembles African-American refugees' successful efforts to transform the Civil War into a war of emancipation and allow the enlistment of black soldiers. See Amy Murrell Taylor's Embattled Freedom: Journeys through the Civil War's Slave Refugee Camps (Chapel Hill: University of North Carolina Press, 2018) and Chandra Manning's Troubled Refuge: Struggling for Freedom in the Civil War (New York: Alfred A. Knopf, 2016).

The United States ultimately raised three Indian Home Guard regiments from Indian Territory, whose service proved integral to military efforts in the region. We can understand their service in the context of both Southern Unionism-Southerners who resisted the Confederacy and who enlisted in the United States army. Indeed, every Southern state except South Carolina provided at least one unit for United States service. United States Colored Troops, many of which were constituted from runaway slaves (some from Indian Territory), proved successful on the battlefield and a vital contribution to the Union war effort. See William W. Freehling, The South vs. The South: How Anti-Confederate Southerners Shaped the Course of the Civil War (New York: Oxford University Press, 2001); Richard Nelson Current, Lincoln's Loyalists: Union Soldiers from the Confederacy (Boston, MA: Northeastern University Press, 1992); Joseph T. Glatthaar, Forged in Battle: The Civil War Alliance of Black Soldiers and White Officers (Baton Rouge: Louisiana State University Press, 1990).
} 
as thousands of Cherokees defected to the Union. In the wake of a Federal invasion and retreat, guerrillas, bandits, and vengeful neighbors — both pro-Union and pro-Confederate — began to terrorize the countryside. Instead of returning the Loyal Indian refugees to their firesides, the expedition only swelled the ranks of the destitute.

Refusing to concede defeat, the Union again invaded Indian Territory the following year. Mirroring the war's crescendo in other theaters, 1863 proved the decisive year of the Civil War in Indian Territory. Detailing the military clashes that summer, Chapter 5 exposes how the Confederacy failed to uphold its treaty obligations to Indian Territory. Poorly clothed and equipped, underpaid, and bereft of quality arms or artillery, Confederate soldiers in Indian Territory fought at a decided material disadvantage in the critical engagements at First Cabin Creek and Honey Springs, the largest Civil War battle in Indian Territory. These material shortfalls_ combined with questionable leadership — contributed to Confederate defeats. These defeats not only gave the Union a permanent foothold in the region, but they also contributed to a wider collapse of the Confederacy's Arkansas River defensive line in the Trans-Mississippi theater. This disastrous turn of military affairs gutted Confederate morale and severely undermined Confederate Indians' faith in their white allies.

The defeat at Honey Springs irrevocably shattered the Confederacy's hold over much of Indian Territory. Unable to challenge Federal forces directly, the Civil War in Indian Territory deteriorated into a series of destructive raids conducted by both sides. Confederate Indians were also drawn into the fighting in southern Arkansas in 1864, participating in the massacre of black soldiers at the Battle of Poison Spring. Chapter 6 chronicles this descent into increasingly violent, racialized warfare and the centrality of guerrilla warfare and raiding to the region's wartime experience. It also surveys the impact of the war upon civilian communities and the 
final return of Loyal Indian refugees to Indian Territory, whose return was not the triumphant homecoming imagined. With neither the Confederate or United States able to exercise full military control over the region, the refugee crisis, famine, disease, and guerrilla warfare plagued the landscape. ${ }^{10}$

The Civil War in Indian Territory devastated the Five Tribes' population, communities, and sovereignty and left them with an uncertain future. In many ways, the Civil War represented the bloody crescendo of years of factionalism stemming from the old Southeastern problems of acculturation, white encroachment, and removal. As Reconstruction loomed, however, new problems arose. With significant portions of all Five Tribes having fought for the Confederacy, and Cherokees, Creeks, and Seminoles having endured intra-tribal warfare, new treaties with the United States needed to be negotiated, and Natives possessed little leverage or unity.

I conclude by offering a brief synopsis of how the Civil War in Indian Territory disastrously undermined Native sovereignty in the face of Reconstruction and paved the way for fundamental new "Western" problems. The United States pushed an agenda of acculturation and assimilation, pan-Indian government that erased tribal distinctions, emancipation and black citizenship, the establishment of railroads, and a demand for yet more land. Ironically, the tribes most loyal to the United States—-the Creeks, Seminoles, and Cherokees—suffered the worst in these negotiations, while the Choctaw and Chickasaws secured more favorable terms. Yet in the end, the Civil War and Reconstruction in Indian Territory marked a new era of increased United

${ }^{10}$ The persistence of guerrilla warfare, its centrality to the conflict in Indian Territory, and its impact on civilians affirms the recent wave of scholarship that contends guerrilla warfare was central to the Civil War, rather than a military sideshow. For more, see Daniel E. Sutherland, A Savage Conflict: The Decisive Role of Guerrillas in the American Civil War (Chapel Hill: University of North Carolina Press, 2013); Brian D. McKnight and Barton A. Myers, eds., The Guerrilla Hunters: Irregular Conflicts during the Civil War (Baton Rouge: Louisiana State University Press, 2007); Matthew Stith, Extreme Civil War: Guerrilla Warfare, Environment, and Race on the Trans-Mississippi Frontier (Baton Rouge: Louisiana State University Press, 2016); Joseph M. Beilein, Jr. and Matthew C. Hulbert, eds., The Civil War Guerrilla: Unfolding the Black Flag in History, Memory, and Myth (Lexington: University Press of Kentucky, 2015). 
States interference in Native affairs, American meddling that would eventually lead to allotment, white settlement, the dissolution of tribal governments, and Oklahoma statehood. ${ }^{11}$

${ }^{11}$ Recent scholars have worked to connect Civil War and Western history, arguing that issues of sovereignty, expansion, and the power of the Federal government and military link these two fields. Civil War Indian Territory bridges that gap, combining traditional Civil War politics and campaigns with Native American struggles for sovereignty and a Federal government increasingly interested in expanding its power and territory in the region. For more on the intersection between the Civil War and the West, see: Adam Arenson and Andrew R. Graybill, eds., Civil War Wests: Testing the Limits of the United States (Oakland: University of California Press, 2015) and Virginia Scharff, ed., Empire and Liberty: The Civil War and the West (Oakland: University of California Press, 2015). For a comparative examination of international settler colonialism, see James Belich, Replenishing the Earth: The Settler Revolution and the Rise of the Anglo-World, 1783-1939 (New York: Oxford University Press, 2009). 


\section{"We Are Choosing in What Way We Shall Die:" Factionalism and Fraud in Confederate-Native Diplomacy, 1861}

"If the North was here so we could be protected, we would stand up for the North. But now if we do not go in for the South, the Texans will come over here and kill us. " -Unknown Choctaws, $1861^{12}$

On Sunday, April 21, 1861 a delegation of Choctaw Indians met with Commissioner of Indian Affairs William Dole and Secretary of the Treasury Salmon Chase in Washington, D.C. It was to be a mundane, if important meeting, regarding payments owed the Choctaw tribe for their Mississippi homelands sold decades ago. Now settled in the southern portion of Indian Territory, the Choctaw commission_-including its leader Peter Pitchlynn-looked forward to concluding years of negotiations, receiving a large settlement, and returning home. ${ }^{13}$

Instead, the meeting quickly took a more ominous turn. Commissioner Dole and Secretary Chase confided to the Choctaws their belief that the Choctaw and Chickasaw Indian agent, Douglas Cooper, harbored Confederate loyalties. Before most of the funds could be dispersed, the United States wanted to know the Choctaws' loyalties and desired a requisition for the funds from the Choctaw General Council to reassure the U.S. of the Choctaws' loyalty. ${ }^{14}$

Peter Pitchlynn and the Choctaw delegation took the disturbing news in stride and shared their own concerns with Dole and Chase. As civil war loomed on the horizon, the Choctaws held “great apprehensions of attacks upon their people, by citizens of Texas and Arkansas.” Hoping to stay above the fray, they declared "their determination to maintain a neutral position in the anticipated difficulties throughout our country." The Choctaws departed for home the next day,

${ }^{12}$ S. Orlando Lee quoted in Annie Heloise Abel, The American Indian as Slaveholder and Secessionist (1915, repr., Lincoln: University of Nebraska Press, 1992), 78

${ }^{13}$ W. David Baird, Peter Pitchlynn: Chief of the Choctaws (Norman: University of Oklahoma Press, 1972), $123-125$

${ }^{14}$ Baird, Peter Pitchlynn, 123-125. 
needing to take stock of political affairs in their country and hoping to secure a requisition for the funds owed. William Dole was pleased with the meeting, and subsequently urged the Federal government to provide the Indians with arms for defense and to maintain troops in Indian Territory to keep order and loyalty among the region's denizens. ${ }^{15}$

The April meeting between the Choctaws and the Federal government laid bare the issues confronting Native Americans of Indian Territory, the United States, and the nascent Confederacy in the spring of 1861. The Five Tribes of Indian Territory-Cherokee, Chickasaw, Choctaw, Creek, and Seminole-found themselves trapped in the continental heart of a nation seized by civil strife. Bordered by Union Kansas and Missouri to the north and Confederate Arkansas and Texas to the east and south, many Native Americans like Peter Pitchlynn hoped to navigate a path of neutrality in the days ahead. Other Natives, however, envisaged a future within the Confederacy, where their slaves and political rights could be better secured. These differing political views were sharpened by cultural clashes over acculturation and old political feuds dating back to removal. Faced with the American Civil War, internal tribal politics pushed and pulled Indians in differing directions and ultimately propelled them to intra-tribal civil wars.

For the Federal government, and especially for Commissioner of Indian Affairs William P. Dole, Indian Territory posed a difficult problem in a season flooded with difficult problems. The firing on Fort Sumter ensured that civil war lay ahead, and as Upper South states seceded the Confederacy grew larger by the week. Troops were needed everywhere, money was needed everywhere, and decisions needed to be made about how to prioritize troops and funds on hand. For the Lincoln Administration and the War Department, Indian Territory hardly registered as a

\footnotetext{
${ }^{15}$ Baird, Peter Pitchlynn, 123-125; William P. Dole to Caleb B. Smith, April 29, 1861, Report Books of the Office of Indian Affairs, 1838-1881 (hereinafter referred to as OIA Report Books), National Archives, Washington, D.C.
} 
consideration. For William Dole and the Office of Indian Affairs, the loyalties and needs of Indian Territory loomed larger. These disjointed priorities of various Federal agencies ultimately led to the disastrous withdrawal of United States forces from Indian Territory, which in turn opened a political vacuum in which the young Confederacy exerted pressure on vulnerable Native Americans.

If the United States' policy towards Indian Territory was shaped by officials in Washington, D.C., the Confederate States' interest in Indian Territory was driven by Arkansans and Texans who anxiously desired to know the loyalties of their Indian neighbors. Confederate Indian agents, military officers, politicians, and citizens took matters into their own hands, using a combination of political pressure, violence and intimidation, occupation, clever politicking, and outright fraud to secure treaties of alliance with the Five Tribes. They were assisted by wealthy, slaveholding Native elites who envisioned themselves as both Southerners and Indians, and who sought to protect their material interest within the Confederacy.

By the autumn of 1861, each of the Five Tribes of Indian Territory had inked treaties of alliance with the Confederate States. Yet these treaties papered over serious cultural political fault lines among Native Americans, exacerbated by the fraudulence with which they were negotiated. Ultimately, Confederate machinations in their alliances with the Confederacy proved their undoing.

The young second lieutenant stepped out of General Winfield Scott's office, having reported for duty and ready for his next assignment—whatever it may be. He didn't have to wait long. That night, lounging in the lobby of the Willard Hotel in the heart of Washington, D.C., the lieutenant was approached by several other United States officers. Invited to play a game of pool, 
the lieutenant quickly learned that more than billiards was at hand. "While engaged in the game," the young officer recalled, "the Captain quietly asked me where I lodged and requested me to go to my room when the game should be finished and he would follow me." At the surreptitious hotel room meeting, the cadre of officers asked the lieutenant "if I was able and willing to undertake a long journey involving an unknown amount of fatigue and danger.” The feisty officer responded, "try me." The task was straightforward: deliver dispatches to the commander of Federal troops in Indian Territory, ordering him to evacuate to the safety of Kansas. It was the night of April 16, 1861, and the next morning Lieutenant William Woods Averell headed west across a disintegrating United States. ${ }^{16}$

Several weeks and 1,300 miles later, Lieutenant Averell and his Indian guide approached the outskirts of Fort Washita, a small Federal post in Chickasaw Nation, Indian Territory. The journey west had been a harrowing one. Traveling in plain clothes, Averell made it to southwest Missouri easily enough. Upon arriving at Fort Smith, Arkansas, where he expected to deliver his orders, Averell discovered the fort was no longer in Federal hands; instead he found "mounted men riding madly, secession flags flying and women displaying them from windows." Trading twenty dollars and his gold watch for a fresh mount, Averell headed west into Indian Territory to chase down the wayward Federal command. In Choctaw Nation, Averell was questioned by men "whose villainous countenances were shaded by Texan sombreros," and when the lieutenant's answers failed to satisfy them, he was forced to flee overland into the brush to escape. Hoping to reach the Federal garrison at Fort Arbuckle, Averell learned from a local sutler that the fort had been abandoned, and the Union garrison had concentrated further west at Fort Washita. ${ }^{17}$

${ }^{16}$ Ten Years in the Saddle: The Memoir of William Woods Averell, 1851-1862, eds. Edward K. Eckert and Nicholas J. Amato (San Rafael, CA: Presidio Press, 1978), 247-250; E.D. Townsend to William H. Emory, April 17, 1861, Official Records, vol. 1, 667.

${ }^{17}$ Eckert and Amato, eds., Ten Years in the Saddle, 250-267. 
And so, after failing to deliver his secret orders to either Fort Smith or Fort Arbuckle, the haggard lieutenant and his local guide warily neared Fort Washita. The pair quickly found that it, too, had fallen and was occupied by hostile Texan militia. Before despair could set in, however, they learned that the Federal garrison was only a few miles up the road. "With my fleet steed and a good will, those six miles were soon accomplished," Averell remembered, "and it was with an exultant heart that I saw my old comrades in arms just forming squadrons for the march." 18

William Averell made his way to the front of the column in search of Lt. Colonel William H. Emory. A noted surveyor and explorer, Emory was found "looking grim as a grizzly bear" astride a horse. "Colonel!" Averell exclaimed, "You don’t seem to know me!” No, I don't," Emory replied. "Who are you?" "I am Lieutenant Averell, with dispatches from Washington, and here they are," Averell replied. Emory's grim countenance transformed, and he cried, “My God! Averell, how did you get here?” Other young officers, riding up, also expressed their curiosity and disbelief. "Not one of them recognized me," Averell recalled. Having survived the harrowing journey, Averell was offered a stiff drink and "was at home under the flag of my country and surrounded by old friends and comrades." ${ }^{19}$

The terrible irony is that Averell's dispatches were nearly obsolete upon delivery. Colonel William Emory hardly needed prompting from Washington to know his situation was dire. Arkansas had seceded and Fort Smith surrendered to the east, and Texan militias were scouting into southern Indian Territory with regularity. As the secession crisis unfolded and the political landscape shifted under Emory's feet, he decided to consolidate the scattered Union garrisons across Indian Territory at Fort Washita, hoping to march north with hist 750 men to Fort Leavenworth, Kansas. Not all the officers under Emory's command agreed with his

\footnotetext{
${ }^{18}$ Eckert and Amato, eds., Ten Years in the Saddle, 267.

${ }^{19}$ Eckert and Amato, eds., Ten Years in the Saddle, 267-273.
} 
decision; there were protests that an evacuation would leave the Five Tribes defenseless, either to aggressive Plains Indians or to the Confederacy. Emory did not budge from his decision, however, believing that Arkansas' secession made Indian Territory too vulnerable to occupy. Thus, the Federal column marched north. For several days they were followed by a party of Texans, and on May 5, Emory sent a small rear-guard force to confront the pursuers. The Texans, perhaps not ready to shed blood, surrendered, a peaceable end to the first military confrontation of the Civil War in Indian Territory. The column finished the journey without incident, reaching Fort Leavenworth by late May. ${ }^{20}$

Back in Washington, D.C., Commissioner of Indian Affairs William P. Dole knew little of Col. Emory's retreat from Indian Territory. Faced with interrupted mail routes, Indian agents of dubious loyalty, and an uncommunicative War Department, Dole was in the dark. In late April, Dole reminded Secretary of the Interior Caleb Smith of the United States' "obligations to protect the Indians from the incursions of all enemies," and asked "to be informed if it is not [the government's] intention to keep in the country a sufficient force." Unaware the War Department had already issued orders to retreat, both Secretary Smith and Commissioner Dole argued for the importance of a Federal force in Indian Territory which would "secure the neutrality of the

20 "Report of Lieut. Col. William H. Emory," May 19, 1861, and W.H. Emory to E.D. Townsend, April 13, 1861, Official Records, vol. 1, 648-649, 665-666; L. David Norris, et. al., William H. Emory: Soldier-Scientist (Tucson: University of Arizona Press, 1998), 196-207. The chapter "Command at Fort Arbuckle" in Emory's biography offers a detailed account of Emory's decision-making process at the outbreak of the Civil War. Emory seems to have understood the predicament in which he was leaving local Indians, but he firmly believed that the security of his forces was paramount. He arrived in Kansas with 750 soldiers and 150 civilians in tow. The soldiers who evacuated Indian Territory were reorganized into the $4^{\text {th }}$ and $5^{\text {th }}$ United States Cavalry regiments and played a vital role in securing Missouri for the Union later that year. Emory enjoyed a successful military career, taking part in the Port Hudson, Red River, and 1864 Valley Campaigns, ending the war in command of a Union corps. In his post-war years he was involved in both the Plains Indian Wars and Reconstruction in Louisiana. 
Indian tribes." If soldiers were unavailable, at least arms could be provided for the Indians' defense. ${ }^{21}$

Simultaneously then, while the Office of Indian Affairs asked for United States troops to secure Indian Territory, the War Department pulled them out. The lack of coordination within the executive and the mismanagement of Indian affairs left the United States devoid of any real presence in Indian Territory. When Colonel William Emory, Lieutenant William Averell, and several hundred Union soldiers reached Kansas, they hardly could've imagined how disastrous their departure would be for the Native Americans they left behind. The Union having departed the region, another year would pass before a blue-clad soldier returned. Their hasty evacuation of Indian Territory represented a complete withdrawal of the United States from the affairs of the Five Tribes during the critical summer of 1861. With the retreat of Emory's column and the United States, the Five Tribes were alone.

Around the same time Lieutenant Averell reached Indian Territory, Peter Pitchlynn likewise made his way home to Choctaw Nation. He found his country in turmoil. Encompassing southern Indian Territory and sharing a long border with Texas, Choctaw and Chickasaw Nations were the first to feel the impact of the brewing conflict between the United States and the Confederacy.

Removed from their lands in Alabama and Mississippi in the 1830s, the Choctaws and Chickasaws resettled in Indian Territory and established prosperous communities along the Red

${ }^{21}$ William P. Dole to Caleb B. Smith, March 29, 1861, April 29, 1861 and May 30, 1861, Charles E. Mix to Caleb B. Smith, September 19, 1861, OIA Report Books, National Archives, Washington, D.C.; Caleb B. Smith to Simon Cameron, May 4, 1861 and May 30, 1861, Letters Sent by the Indian Division of the Office of the Secretary of the Interior (hereinafter referred to as Indian Division, Letters Sent), National Archives, Washington, D.C. 
River and Canadian River Valleys. Missionaries opened academies, preaching Christianity and teaching English, writing, and arithmetic. Native Americans traded with the white neighbors in Texas, and they sent their goods and crops down the Red River to the Mississippi River and New Orleans. The Choctaw Intelligencer offered local and national news to its readers. Although their position near the Texan plains prompted occasional raids by Plains Indian tribes, antebellum Federal posts at Forts Arbuckle, Cobb, and Washita guarded their southwestern frontier. In 1855, the Chickasaw, who had resided since removal under Choctaw rule, were granted their independence and carved their own Chickasaw Nation out of south-central Indian Territory.

Like the other Five Tribes, the Choctaws and Chickasaws had undergone centuries of acculturation, and years of interacting with white Southerners prompted the Choctaws and Chickasaws to embrace the institution of chattel slavery. Although most Native Americans engaged in subsistence farming and owned few, if any slaves, a small but deeply influential planter elite arose who owned significant plantations and relied heavily upon slave labor. One of the richest men in Indian Territory, Choctaw planter Robert M. Jones oversaw six plantations that produced hundreds of bales of cotton annually, sent downriver in Jones' own steamboat. Two hundred and twenty-seven slaves worked Jones' fields, and on the backs of their labor he became the first millionaire in Choctaw Nation. Wealthy men like Jones, often of mixedancestry, were undoubtedly invested in the protection and expansion of slavery. Hardening racial views in antebellum Choctaw Nation attest to the political importance of slavery. All free blacks were expelled from Choctaw Nation in 1840, and after 1846, manumission of Choctaw slaves required the approval of the national legislature. Slavery served as a bedrock within Choctaw and Chickasaw societies and economies. ${ }^{22}$

\footnotetext{
${ }^{22}$ Michael L. Bruce, “'Our Best Men Are Fast Leaving Us': The Life and Times of Robert M. Jones,” Chronicles of Oklahoma 66, no. 3 (1988), 295-296.
} 
Although Peter Pitchlynn had advised William Dole of the Choctaws' desire for protection and neutrality, wealthy slave-owners like Robert Jones thought differently. Upon Pitchlynn's return to Choctaw Nation, he was surprised to discover serious steps had already been taken by the Choctaw General Council in preparation for a possible split with the United States. Back in February, the Council issued a resolution "that in the event a permanent dissolution of the American Union takes place...we shall be left to follow the natural affections, education, institutions, and interests of our people, which indissolubly bind us in every way to the destiny of our neighbors and brethren in the Southern States." The resolution especially sought "to assure our immediate neighbors, the people of Arkansas and Texas, of our determination to observe the amicable relations in every way so long existing between us." In March, delegations from the Choctaw and Chickasaw Nations met to coordinate their efforts as secession progressed. ${ }^{23}$

Yet as spring advanced, events began to unfold more rapidly and the first signs of both external intimidation and internal rifts among the Choctaws began to appear. When the United States Army evacuated Forts Arbuckle, Cobb, and Washita in May, Texan militia companies seized the opportunity to secure their northern border and occupied the former U.S. military posts. The sudden appearance of armed Texan troops within Choctaw and Chickasaw borders left some Indians uneasy. "Arrived home yesterday," Choctaw Sampson Folsom penned, "but find our lovely country in the hands of Texanian [sic] filibusters. They are making inroads upon our soil under the plea of driving out the military of the United States, with whom," Folsom

23 "Resolutions expressing the feelings and sentiments of the General Council of the Choctaw Nation," February 7, 1861, Official Records, vol. 1, 682; "Resolutions Passed by the Convention of the Choctaws and Chickasaws," March 11, 1861, Peter Pitchlynn Papers, Helmerich Center for American Research, Thomas Gilcrease Institute of American History and Art, Tulsa, Oklahoma (hereinafter referred to as Gilcrease Institute); Angie Debo, The Rise and Fall of the Choctaw Republic (1934, repr., Norman: University of Oklahoma Press, 1961), 80-81. 
noted, "we have treaty obligations." This was unacceptable, Folsom thought, since "what they will do next is make white settlement in our midst." Folsom even went so far as to claim he "was for raising five thousand Choctaws and Chickasaw troops at once to keep out Land Pirates and abolitionists." Having been removed from his homeland once already in his lifetime, Folsom worried that Texas occupation was the opening act of yet further white encroachment. ${ }^{24}$

The Texan occupation of Fort Washita and other posts was hardly the only violation of Choctaw and Chickasaw sovereignty that spring. In May, Texan vigilantes launched a dedicated campaign to drive out missionaries - many of whom hailed from the North and were suspected of being abolitionists - from Choctaw and Chickasaw Nations. An early target of the Texans' ire was Reverend Horace A. Wentz of New York, who had been engaged in illicit arms trafficking by selling revolvers and carbines around Choctaw Nation. On May 20, the arms-dealing reverend was accosted by a party of "rough fellows" who "seized...bound and carried [him] back to Doaksville" in Choctaw Nation. The vigilantes "fired revolvers about his ears," but the New Yorker remained defiant at the prospect of death. At the behest of a local merchant, Wentz was freed and fled north. Wentz hurried out of Indian Territory and within a week of his capture and release, he sat safely ensconced in Cincinnati, Ohio, where he had once gone to school at Lane Theological Seminary, a bastion of anti-slavery thought. ${ }^{25}$

${ }^{24}$ Otis G. Welch to Joseph A. Carroll, May 12, 1861, Private Collection of Jim McDermott (digitized), University of North Texas Libraries, The Portal to Texas History, Denton, TX; Sampson Folsom to P.P. Pitchlynn, May 14, 1861, Peter Pitchlynn Papers (digitized), Western History Collection, University of Oklahoma, Norman, OK (hereinafter cited as WHC, OU); Ainslie to Lowrie, July 13, 1861, and H. Ballentine to J. Leighton Wilson, May 5, 1861, American Indian Correspondence, Presbyterian Historical Society, Philadelphia, PA (hereafter cited as AIC, PHS). Emphasis in the original text.

${ }^{25}$ John Edwards, "My Escape from the South in 1861," Chronicles of Oklahoma 43, no. 1 (1965), 61-63; Ainslie to Lowrie, July 13, 1861, AIC; H.A. Wentz to J.L. Wilson, May 27, 1861, AIC, PHS; General Catalogue of Lane Theological Seminary 1828-1881 (Cincinnati: Elm Street Printing Co., 1881), 34-35. For a greater exploration of Texan vigilantism and the Choctaw Nation's alliance with the Confederacy, see Zachery Cowsert, "Political Machinations, Texan Intimidations: The Choctaw Nation Enters the Civil War," Chronicles of Oklahoma 94, no. 2 (Summer, 2016): 186-207. 
The kidnapping of Reverend Wentz had far more to do with the simple, if illegal, sale of revolvers. Fellow missionary Calista B. Downing revealingly reported back to her superiors in New York that "Mr. Wentz by selling revolvers secretly, has been 'suspected' of abolitionism, and there is so much excitement, not only in the Nation, but among our Texas and Arkansas neighbors." Indeed, the harsh reaction to Rev. Wentz's sale of revolvers was merely a manifestation of a much larger fear of abolitionism, a fear that existed on both sides of the Choctaw-Texan border. And although Wentz had escaped the Texans' grasp, they remained determined to "sweep the Territory from the Texas border to the Kansas line, 'cleaning out' northern men everywhere." Abolitionists "should go up," according to the Texans, indicating their desire to hang any anti-slavery men they found. ${ }^{26}$

Horace Wentz' arms-dealing gave Texans an excuse to prowl Choctaw Nation and determine the political sentiments of its missionaries. On the day Wentz was arrested, a "small company of Texans," arrived at the home of missionary John Edwards. "Their first object," Edwards reported, "was to search for revolvers. I let them search to the hearts' content." Unable to find any weapons in Rev. Edwards' home, they soon began to question his political leanings. Although Edwards assured them he was not an abolitionist, trouble arose when Edwards refused to pledge that he "would take up arms for the South" in the event of war. The captain ordered Edwards to leave the Territory, but upon learning that the missionary's young son was sick, ordered the family to leave when the boy recovered. Edwards' exodus was hastened when his "friends at Doaksville learned that a conspiracy was formed to go and hang him." Edwards fled north. ${ }^{27}$

\footnotetext{
${ }^{26}$ C.B. Downing to J.L. Wilson, April 27, 1861, AIC, PHS; Department of the Interior, Report of the Commissioner of Indian Affairs for the Year 1861 (Washington: Government Printing Office, 1861), 47.

${ }^{27}$ John Edwards to J.L. Wilson, May 24, 1861, AIC, PHS; Ainslie to Lowrie, July 13, 1861, AIC, PHS.
} 
Other missionaries faced similar encounters with Texan intruders. On Tuesday, May 21, an "armed mob...mostly from Texas" arrived at Spencer Academy at noon. The Texans arrived at Spencer Academy "ostensibly for the purpose of searching for arms \& ammunition supposed to be secreted there." Their excuses failed to fool George Ainslie, however, who determined that the Texans' "true purpose was to hang Mr Wentz had he been found." Rev. C.C. Copeland also received a vigilante visit; faces in the mob were "blackened and otherwise disguised." "I have been compelled by lawless men," Copeland complained, "to leave my field for the present at least. The Vigilant Committee who ordered me away, gave me no reasons for their procedure, so that I am ignorant of the charge against me." Copeland sought shelter with friends near Paris, Texas. $^{28}$

These threats of violence compelled most missionaries to leave Choctaw Nation. Calista Downing determined that "there is a class of persons in this neighborhood who 'respect nothing but revolvers." Horace Wentz similarly complained from Cincinnati that "there is along the Texas line on both sides the fence a set of men whose character has no parallel this side of the Infernal legions." Nancy Shepherd lamented for the "poor girls of my charge here...if we are withdrawn from the field." Sue McBeth declined to provide the "sad details of the breaking up of our missions... and the dark cloud that overhangs \& envelops."29

Just as the Texan occupation of forts within Indian Territory left certain Choctaws uneasy, Texan vigilantism likewise worried certain Native Americans. To be sure, the Choctaws

${ }^{28}$ George Ainslie to J.C. Lowrie, July 13, 1861, AIC, PHS; Anna Warner, A Servant of the King: Incidents in the Life of the Rev. George Ainslie (New York: John Ireland, 1889), 4-14; Ainslie to Lowrie, July 13, 1861; C.C. Copeland to Walter Lowrie, July 30, 1861, AIC, PHS. A posthumous account of Ainslie's life entitled A Servant of the King contains a dramatic, likely embellished, account of the Texas "Vigilants" and their threats to Rev. Ainslie. Interestingly, in this somewhat dubious account, Ainslie's life is threatened because he "preached to coloured people as well as to Indians." In general, however, I have relied upon the contemporary 1861 correspondence of Ainslie and others to determine what occurred.

${ }^{29}$ Downing to Wilson, April 27, 1861, AIC, PHS; Wentz to Wilson, May 17, 1861, AIC, PHS; Nancy G. Shepherd to Wilson, May 4, 1861, AIC, PHS; Sue McBeth to Walter Lowrie, July 9, 1861, AIC, PHS. 
were no friends of abolitionism and moreover, some Choctaws privately expressed their dissatisfaction with the missionaries' presence. "I am of the opinion," declared Choctaw George Harkins in 1853, "that those stinking abolitionists will yet cause the Choctaws a great deal of trouble... They are a treacherous hypocritical set of Yankees." Harkins continued angrily, "I am done with missionary schools...I want to see Choctaw have independence about them. Show some resentments when their rights are trampled on." Yet these violations of Choctaw and Chickasaw sovereignty angered many. Missionary George Ainslie acknowledged that "the Choctaws are now arroused [sic] by these invasions of their territory and meetings were held to organize and arm in home defence [sic]. ${ }^{30}$

Texan occupation of Federal forts and Texan vigilantism across southern Indian Territory did not meet with the approbation of all Choctaws and Chickasaws. This unease hardly suggests an immediate willingness to cooperate with Texas or the Confederacy; moreover, it made clear that Texans and Southerners would prioritize their defense and foreign policy designs over Native American sovereignty. Finally, Texan interference within Chickasaw and Choctaw Nations sent a clear message to all those unwilling to offer anything but their full-throated support for the Confederacy: stay silent or leave.

It is clear many of the wealthy, slave-holding members of Choctaw General Council supported an alliance with the Confederacy. It is far less clear, however, how many of the poorer, non-slaveholding, less acculturated Choctaws and Chickasaws felt about the possibility of allying with the South and entering the war. Many Chickasaws and Choctaws were traditionalists who embraced ancestral ways of clothing, farming, religion, and language. Most did not speak English, much less write it. Yet the correspondence and reports of missionaries long embedded

${ }^{30}$ Geo. W. Harkins to Col. Pitchlynn, October 19, 1853, Peter Pitchlynn Papers, WHC, OU; George Ainslie to J.C. Lowrie, July 13, 1861, AIC, PHS. 
within these tribes offer a window into the sentiments of everyday Indians on the verge of the Civil War.

Writing to each other and their superiors back east, missionary correspondence hardly reveals a wave of war fever or Confederate nationalism among common Choctaw and Chickasaws. In April of 1861, Reverend C.C. Copeland reported, "There is some commotion among the Choctaws in regard to the division among the states, some wishing to secede, but the majority opposed to secession for the present." In May, Copeland reiterated his message: "We have just heard exciting news of war. The Choctaws \& Chickasaws are trying to be quiet and take no part in the strife, but whether they will be allowed to do so or not is uncertain." Copeland's assessment suggests that many Choctaws and Chickasaws wanted no part in the coming war. Rev. S. Orlando Lee was told that "the full bloods were strongly for the north." ${ }^{31}$ Rev. Lee's allusion to blood is an intriguing one. To a greater or lesser extent, all of Indian Territory's Five Tribes contained intra-tribal factions divided along ancestral and, more importantly, cultural lines. Generally, "full-blood" Native Americans tended to preserve traditional Indian attitudes and ways of life, while "mixed-blood" Indians embraced acculturation and adopted white_-particularly Southern—-lifestyles. Within the Cherokee, Creek, and Seminole tribes, debates over allying with the South and subsequent Civil War exposed the seriousness of the fault lines that divided these factions, ultimately leading to intra-tribal bloodshed.

Racial and especially cultural divisions existed within the Choctaw as well. Scholars have well documented how "progressives" of mixed ancestry often stood at odds with "conservatives" within the Nation. As Richard White deftly explains of the progressives: "They were, for all their

${ }^{31}$ C.C. Copeland to J.L. Wilson, April 18, 1861, AIC, PHS; C.C. Copeland to J.L. Wilson, May 2, 1861, AIC, PHS; S. Orlando Lee quoted in Abel, The American Indian as Slaveholder and Secessionist, 78. 
patriotism, different from their countrymen. Their interests and attitudes reflected their position as the children of white fathers, the settlers of the borderlands, the owners and heirs of the cattle herds and later the cotton plantations." On the outbreak of the Civil War, it was the progressives, aided by Texas vigilantes, who strove to forge a Choctaw-Confederate alliance. While S. Orlando Lee might have been overzealous in declaring "the full bloods were strongly for the north," especially given their desire to generate sympathy and funds back home, it seems likely that the greatest support for neutrality existed among full-blooded Choctaw conservatives. ${ }^{32}$

Whatever the extent of support for neutrality, the best hope for Choctaw neutralists rested with Peter Pitchlynn. Despite his own status as a wealthy, educated, acculturated Choctaw leader, Pitchlynn's years spent in Washington, D.C. and the North exposed him to wider American society and fostered a lackluster attachment to slavery. Moreover, having returned from his recent negotiations in Washington, he was eager to the see the Choctaw Nation remain loyal to the United States and receive the payments he had negotiated. ${ }^{33}$

Pitchlynn worked assiduously to ensure that his tribe would remain neutral, at least for the time being. Knowing the broad support for the Confederacy among the General Council members, Pitchlynn's tactic was to convince Principal Chief George Hudson that neutrality remained the best course of action. Working with Hudson, Pitchlynn drafted a message for Hudson to deliver to the General Council in June recommending neutrality. In the speech, Pitchlynn argued the Choctaws were legally bound to the United States by treaties. These treaties

${ }^{32}$ Michael C. Coleman, Presbyterian Missionary Attitudes toward American Indians, 1837-1893 (Jackson: University of Mississippi Press, 1985), 60-62; Richard White, The Roots of Dependency: Subsistence, Environment, and Social Change among the Choctaws, Pawnees, and Navajos (Lincoln: University of Nebraska Press, 1983), 116-117; S. Orlando Lee quoted in Abel, American Indian as Slaveholder and Secessionist, 78; Paul Bonnifield, "The Choctaws on the Eve of the Civil War," in The Civil War Era in Indian Territory (Los Angeles: Lorrin L. Morrison, 1974). Paul Bonnifield's essay "The Choctaws on the Eve of the Civil War" offers great insight into the cultural and political divisions among the Choctaw just prior to the outbreak of the Civil War.

${ }^{33}$ Baird, Peter Pitchlynn, 156. 
gave the Choctaws "a complete title \& right to the land we now live on" and moreover noted "all our interest funds are now in the hands of president Lincoln." Although Pitchlynn conceded that "we cannot and must not oppose our Southern friends," he believed continuing relations with the United States was the best course at present. Finally, he called for unity in the face of an uncertain future: "Let us be Choctaws, let us be as one people, our only hope is to have a union among ourselves." Pitchlynn's tactic worked. "[Pitchlynn] gave all his influence to have the Choctaws take a neutral position," commented Reverend Lee. "Col. P. so far succeeded as to induce him [Chief George Hudson] to prepare a message recommending neutrality." ${ }^{34}$

Despite his success in swaying Chief Hudson towards neutrality, Pitchlynn's political campaigning did not go unnoticed by his political opponents. Pitchlynn soon received the missionary treatment and was visited by an armed mob of Texan vigilantes who called him an "abolitionist" and threatened his life. It was clear that if the Choctaw leader should continue to support neutrality, his life may be forfeit. ${ }^{35}$

In late May, hope for neutrality eroded further when the Chickasaw legislature passed resolutions which dissolved their treaties with the United States, proclaiming "our geographical position, our social and domestic institutions, our feelings and sympathies, all attach us to our Southern friends." The Chickasaws moreover believed the Lincoln Administration would wage "a war of subjugation or extermination...[which] will surpass the French Revolution in scenes of blood and that of San Domingo in atrocious horrors" and called upon neighboring Indian tribes to united in defense against "Lincoln hordes and Kansas robbers." The Chickasaws authorized

${ }^{34}$ Debo, Rise and Fall of the Choctaw Republic, 81; Baird, Peter Pitchlynn, 126-127; Undated, unsigned speech draft, Peter Pitchlynn Papers, Gilcrease Institute; Abel, American Indian as Slaveholder and Secessionist, 7778; S. Orlando Lee quoted in Abel, American Indian as Slaveholder and Secessionist, 77-78.

${ }^{35}$ Debo, Rise and Fall of the Choctaw Republic, 81; Clayton E. Jewett, Texas in the Confederacy: An Experiment in Nation Building (Columbia: University of Missouri, 2002), 83; S. Orlando Lee quoted in Abel, American Indian as Slaveholder and Secessionist, 77-78. 
negotiations of alliance with the Confederacy, and they specifically declared "the Chickasaws look with confidence especially to the Choctaws... and hope they will speedily unite with us in such measures as may be necessary for the defense of our common country and a union with our natural allies, the Confederate States of America." ${ }^{" 36}$

Following the Chickasaw resolutions, in early June pro-secessionist Choctaws and Texans met in Doaksville, a prominent town within Choctaw Nation, to discuss the matter of breaking ties with the Union and allying with the Confederacy. The meeting "was largely attended by white men from Texas." Also present was George Hudson, Principal Chief of the Choctaw Nation and well-coached by Pitchlynn on the merits of neutrality. Unbeknownst to Hudson, however, was that his and Pitchlynn's agreement on neutrality had become known to the pro-secession Choctaws and Texans in attendance. The pro-Southern Choctaws had learned of Hudson's newfound neutrality from Douglas H. Cooper, the once-Federal Indian agent to the Choctaws and Chickasaws and an ardent secessionist. ${ }^{37}$

Hudson was immediately upstaged and ambushed. He was not the first to speak. Instead, the impassioned and angry Robert Jones, slaveowner and ardent secessionist, took the floor and demanded that "any one who opposed secession ought to be hung" and "any suspicious persons ought to be hung." The whites from Texas continued the verbal onslaught, lobbying for a Choctaw-Confederate alliance. Facing a hostile crowd comprised of both his fellow Choctaws and Texans, who had well-proved their proclivity for vigilantism, George Hudson was thoroughly cowed. ${ }^{38}$

36 "Resolutions of the Senate and House of Representatives of the Chickasaw Legislature assembled," May 25, 1861, Official Records, vol. 3, 585-587.

${ }^{37}$ S. Orlando Lee, quoted in Abel, American Indian as Slaveholder and Secessionist, 77-78; Baird, Peter Pitchlynn, 127; Debo, Rise and Fall of the Choctaw Republic, 81-82.

${ }^{38}$ S. Orlando Lee, quoted in Abel, American Indian as Slaveholder and Secessionist, 77-78; Baird, Peter Pitchlynn, 127; Debo, Rise and Fall of the Choctaw Republic, 81-82; Jewett, Texas in the Confederacy, 83. 
When the Choctaw General Council met a few days later, Chief Hudson abandoned Peter Pitchlynn, his prepared statement, and neutrality. Instead of holding fast to treaties with the United States, Hudson now argued those treaties were broken. "They [the United States] have refused to pay us our money guaranteed and appropriate to us by Act of Congress... and have abandoned military posts placed in our country for our protection." Hudson further warned that the North would invade Indian Territory. Pointing to their shared border and institutions with the South, Hudson advocated the Choctaws "stand by them as our only hope. They will stand by us and cordially join us in defending our rights." Hudson finished by recommending a host of resolutions, including a formal "Treaty of alliance and amity" with the Confederacy, the organization of the Choctaw militia, and finally a "league of confederation" with their fellow Chickasaws, Seminoles, Creeks, and Cherokees to ensure Indian unity. ${ }^{39}$

Although Hudson buckled under secessionist pressure, the General Council proved more reluctant to carry through Hudson's recommendations. According to Rev. Lee, “They feared that their action would result in the destruction of the nation." Joseph Folsom supposedly claimed, "We are choosing in what way we shall die." Lee reported that various Choctaws told him "if the north was here so we could be protected we would stand up for the north but now if we do not go in for the south the Texans will come over here and kill us." 40

On June 10, the Choctaw General Council declared themselves an "absolutely and unconditionally free and independent people" and "ready and willing to enter into a Treaty of Alliance and Amity with the Southern Confederacy." In the adopted resolutions, the Choctaws spelled out their reasons, including the apparent dissolution of the Union, the abandonment of the

${ }^{39}$ Debo, Rise and Fall of the Choctaw Republic, 81-82; Hudson, "Gentlemen of the General Council of the Choctaw Nation," Peter Pitchlynn Papers, Gilcrease Institute.

${ }^{40}$ Joseph Folsom and S. Orlando Lee quoted by S. Orlando Lee, quoted in Abel, American Indian as Slaveholder and Secessionist, 77-78. 
Territory by the U.S. military, and the threat of "invasion by the abolition hordes of the North." On June 14, George Hudson announced the decision publicly at Doaksville and outlined the creation of a "mounted regiment of Choctaw and Chickasaw riflemen called for by the Confederate States of America." Command of the regiment was given to Douglas H. Cooper, the now former U.S. Indian agent who had leaked Chief Hudson's stance on neutrality to the secessionist camp. The Choctaw Nation had joined the Confederacy and entered the Civil War. ${ }^{41}$

On June 22, 1839, three heinous murders were carried out across Cherokee Nation and Arkansas. Pulled from his bed by a party of assailants at dawn, John Ridge was dragged out into the yard, his screaming wife and children kept at bay. Several attackers held Ridge in place, while another lifted a knife and stabbed Ridge twenty-six times, the last being a slice across the throat. That night, in "a scene of agony...[which] has darkened my mind with an eternal shadow," Ridge's son Rollin watched as his mother wept beside her dead husband and Cherokee men filed past the body to pay their respects. "And in addition to all these, the wife, the mother, and the little children, who scarcely knew their loss, were the dark faces of those who had been the murdered man's friends, and possibly some who had been privy to the assassination, who had come to smile over the scene."${ }^{42}$

Elias Boudinot left a Christian missionary that same morning, when he was approached by four Cherokees asking for his assistance in procuring medicine. As he turned back to the missionary to retrieve the medicine, he was stabbed in the back. A tomahawk was then used to

\footnotetext{
41 "Acts and Resolutions passed at the called Session of the General Council of the Choctaw Nation, in June 1861," Peter Pitchlynn Papers, WHC, OU; "Proclamation by the Principal Chief of the Choctaw Nation," Official Records, vol. 3, 593-594.

${ }^{42}$ John Rollin Ridge quoted in Thurman Wilkins, Cherokee Tragedy: The Ridge Family and the Decimation of a People (Norman: University of Oklahoma Press, 1986), 335-336; James W. Parins, John Rollin Ridge: His Life \& Works (Lincoln: University of Nebraska Press, 2004), 29-31.
} 
hack his skull to pieces. An observer witnessed the scene and sent a runner to warn Stand Watie, Elias Boudinot's brother, that his life may also be in danger. Watie escaped to safety, but snuck back that night to gaze upon his dead brother's visage alongside a growing crowd. He offered ten thousand dollars for the names of the murderers. The crowd was silent. ${ }^{43}$

The same day, Major Ridge rode along an Arkansas road, heading back to Cherokee Nation from Van Buren and just a mile from the Cherokee line. A group of assassins waited patiently with rifles perched, and when Major Ridge came into view, they riddled him with five bullets. A slave accompanying Ridge fled the scene and spread the word. ${ }^{44}$

John Ridge, Elias Boudinot, and Major Ridge, along with Stand Watie and a select few other prominent leaders, had all signed or supported the Treaty of New Echota, inked with the United States government four years earlier in 1835. The treaty ceded all Cherokee lands east of the Mississippi River to the United States in exchange for new lands in the west, five million dollars in payment, and funds for the journey. To the Ridges, Boudinot, Watie, and others who came to be known as the "Treaty Party," removal was a mournful but necessary step to preserve Cherokee Nation and its sovereignty as white encroachment on Cherokee lands continued to mount. "I am one of the native sons of these wild woods," Major Ridge declared. "We can never forget these homes, I know, but an unbending, iron necessity tells us we must keep them. I would willingly die to preserve them, but any forcible effort to keep them will cost us our lands, our lives and the lives of our children." 45

Yet the majority of the Cherokee Nation, including its executive Chief John Ross, firmly opposed removal. The Treaty of New Echota did not enjoy the support of the Cherokee

${ }^{43}$ Wilkins, Cherokee Tragedy, 336-338.

${ }^{44}$ Wilkins, Cherokee Tragedy, 338.

45 John Ehle, Trail of Tears: The Rise and Fall of the Cherokee Nation (New York: Anchor Press, 1988), 293-296; Major Ridge quoted in Wilkins, Cherokee Tragedy, 285-290. 
government or its people. It was signed by a minority of Cherokees in direct violation of Cherokee law, which decreed the penalty for the cession of Cherokee lands without tribal approval was death. Ironically, the author of this 1829 law was John Ridge. The Cherokee signers at New Echota knew what they had done; upon signing the document, Major Ridge reportedly stated, "I have signed my death warrant." 46

Over the next several years, most notably in 1838 , approximately 18,000 Cherokees were forcibly removed from their eastern homelands via the infamous "Trail of Tears." As many as 8,000 Cherokees perished during the journey. Upon arrival in Indian Territory, west of Arkansas, the Cherokees found themselves in three camps: the Treaty Party, the Anti-Treaty (or Ross) Party, and the Old Settlers, who had willingly moved to the Territory years prior. Attempts to unify the fractious Cherokees failed, and it was in this chaotic environment that Major Ridge, John Ridge, and Elias Boudinot were murdered. ${ }^{47}$

Their assassins were Cherokee men carrying out the "blood law" of the Cherokee Nation; executing the Treaty men for their betrayal at New Echota. Yet the slayings were not sanctioned by John Ross or other prominent Cherokee officials, and the killings unleashed a wave of reprisals, assassinations, and murders that swept across Cherokee Nation for years. Only in 1846 did the violence come to a halt, as the three factions unified under a single Cherokee national government via a treaty signed at Washington, D.C. John Ross and Stand Watie supposedly shook hands. But the old feuds were not forgotten, nor forgiven. ${ }^{48}$

${ }^{46}$ Major Ridge quoted in Wilkins, Cherokee Tragedy, 289, 334.

${ }^{47}$ Grace Steele Woodward, The Cherokees (1963, repr., Norman: University of Oklahoma Press, 1988), 218; William L. Anderson, Cherokee Removal: Before and After (Athens: University of Georgia Press, 1991), 93. 4,000 Cherokee deaths on the Trail of Tears is a common figure cited, but Russell Thornton make a compelling demographic case that the figure was closer to 8,000 deaths in his essay in Cherokee Removal.

${ }^{48}$ Wilkins, Cherokee Tragedy, 334-335; Woodward, The Cherokees, 224-225, 236-237. 
Although the Cherokees enjoyed a few short years of peace, by the late 1850s, rising sectionalism and tensions over slavery nationally spilled over into Cherokee Nation. A pair of Baptist missionaries, Evan Jones and his son John, brought abolitionism into Cherokee Nation with a "sincere desire and earnest prayer that [slavery] may be speedily brought to an end." While the Joneses quietly spread their anti-slavery ideals among traditionalist Cherokees, wealthier, slaveholding Cherokees began forming their own pro-slavery institutions. By 1855, a pro-slavery secret society emerged within Cherokee Nation, perhaps first taking shelter within the local Cherokee Masonic lodge, but by 1860 emerging as a distinct Cherokee chapter of the pro-slavery Knights of the Golden Circle, a secret fraternal order that spread across the South advocating the emergence of a slave empire throughout the American South, Caribbean, and Central America (hence "golden circle" of slavery). In the Cherokee charter, Stand Watie, John Rollin Ridge, Elias Cornelius Boudinot, and many other Treaty Party member swore "to form a more perfect union and protect ourselves and property against the works of Abolitionists."49

In response, traditionalist Cherokees opposed to the growing influence of white culture and slavery formed the Keetoowah Society in 1858. Present at the founding were prominent Cherokee leaders, including Lewis Downing and Thomas Pegg, and Reverends Evan and John Jones. Politically linked to John Ross, the Keetowah wore two crossed pins on their shirts as signs of their membership, and hence were often referred to as "Pin Indians." Comprised of traditional, conservative Indians, the Keetowah practiced a syncretic religion that blended aspects of Christianity, Cherokee tradition, and brotherhood. An eventual constitution further declared, "Only fullblood Cherokees uneducated, and no mixed blood friends shall be allowed to become a member.” Although generally anti-slavery, as scholar William McLoughlin has deftly

\footnotetext{
${ }^{49}$ Patrick N. Minges, Slavery in the Cherokee Nation: The Keetoowah Society and the Defining of a People, 1855-1867 (New York: Routledge, 2003), 71-73.
} 
argued, the "immediate purpose of the Keetowah Society was to combat those mixed-bloods who wanted to link the Cherokees' destiny to that of the white southern nationalist movement in the United States." The emergence of abolitionism and the creation of anti- and pro-slavery secret societies within Cherokee Nation were igniting along older cultural and political fault lines which had laid dormant for over a decade. The approach of the Civil War threatened to fan the burning embers into a conflagration. ${ }^{50}$

In late May of 1861, Albert Pike stepped off a steamboat from Little Rock into the frontier town of Fort Smith. Portly and bearded, Pike's large figure embodied both his wellknown reputation in Arkansas and his high estimation of his own abilities. A former Arkansas newspaperman and lawyer, Pike served briefly in the Mexican War. During the 1850s, he returned to law and successfully represented the Creek, Choctaw and Chickasaw Nations in legal claims against the Federal government. A prominent Freemason, a self-styled poet and freethinker, Pike was well known in Arkansas social and political circles. In the eyes of Confederate Secretary of State Robert Toombs, Pike's credentials marked him as an excellent choice to serve as Confederate commissioner to the Native American tribes west of Arkansas. Tasked with forging treaties of amity and alliance, Pike confidently set out from Fort Smith into Indian Territory. ${ }^{51}$

As the Confederacy's official envoy to Indian Territory, Pike symbolized the interest held by the Confederate States in securing alliances with Native Americans. Southern hopes of

${ }^{50}$ Minges, Slavery in the Cherokee Nation, 73-85; William G. McLoughlin, After the Trail of Tears: The Cherokees' Struggle for Sovereignty, 1839-1880 (Chapel Hill: University of North Carolina Press, 1993), 154-156.

${ }^{51}$ Albert Pike to Robert Toombs, May 20, 1861, Official Records, vol. 3, 580-581; Albert Pike to D.N. Cooley, February 17, 1866, The Cherokee Question: Report of the Commissioner of Indian Affairs to the President of the United States, June 15, 1866. (Washington, D.C.: Government Printing Office, 1866), 23-28. 
securing Indian alliances emanated from two different points, for varying reasons. For the Confederate government in Richmond, securing Indian Territory seemed a matter of national interest and security. Rebel officials suspected the United States held designs upon Indian Territory and would occupy the land and liberate the Indians' slaves. This was hardly the case, as the Union army's abrupt withdrawal from Indian Territory in May indicates. Nevertheless, Confederate assumptions of Federal aggression promoted, as Secretary of War Leroy Walker stated, "the earnest desire of the Confederate States to defend and protect them [the Indians] against the rapacious and avaricious designs of their and our enemies at the North.” To secure military control of Indian Territory, the Confederacy required alliances with the Five Tribes. Brigadier General Benjamin McCulloch was appointed to command the District of Indian Territory "to guard that Territory against invasion from Kansas or elsewhere," while Albert Pike was sent to negotiate the treaties. ${ }^{52}$

While the Confederate government in Richmond wanted alliances with the Native tribes of Indian Territory, local Arkansans and Texans felt they needed such alliances. As witnessed in the Chickasaw and Choctaw Nations, Trans-Mississippi Southerners closely monitored political affairs in Indian Territory, believing the Indians' allegiance was vital to their safety. From the start of the secession crisis, Arkansans fretted over the loyalties of their Native neighbors to the west. In January, 1861, secessionist commissioner David Hubbard reported "the counties bordering on the Indian Nations... would hesitate greatly to vote for secession, and leave those Tribes still under the influence of the Government at Washington." Hubbard believed "these Indians are at a spot very important, in my opinion, in this great sectional controversy, and must

\footnotetext{
${ }^{52}$ Leroy Walker to Douglas H. Cooper, May 13, 1861, Samuel Cooper to Benjamin McCulloch, May 13, 1861, and Leroy Walker to David Hubbard, May 14, 1861, Official Records, vol. 3, 574-578.
} 
be assured that the South will do as well as the North, before they can be induced to change their alliances and dependence."53

Arkansans demanded to know the Indians' allegiance in any upcoming conflict. Governor Henry Rector warned Cherokee Chief John Ross that "the Indian country west of Arkansas is looked to by the incoming administration of Mr. Lincoln as fruitful fields, ripe for the harvest of abolitionism, freesoilers, and Northern mountebanks. We hope, to find in your people," Rector urged, "friends willing to co-operate with the South in the defense of her institutions, her honor, and her firesides, and with whom the slaveholding States are willing to share a common future." $" 54$

Living less than ten miles from the Cherokee line, the citizens of Boonsboro, Arkansas were more direct with Chief Ross. "We have a right to know, what position will be taken by those who may greatly conduce to our interests as friends, or to our injury as enemies," a committee of prominent citizens declared. "Not knowing your political status with this present contest, as the head of the Cherokee Nation, we request you to inform us by letter... whether you will co-operate with the northern or southern sections... we prefer an open enemy to a doubtful friend." ${ }^{, 55}$

Cherokee Chief John Ross rebuffed these early inquests as to Cherokee intentions. To Henry Rector, Ross deftly reminded the governor of the Cherokees' existing treaties with the Federal government; "thus, the Cherokee people are inviolably allied with their white Brethren of the U. States in War-and friends in peace." Yet he also promised that Cherokee "institutions,

${ }^{53}$ William R. Smith, "Report of Hon. David Hubbard, Commissioner to Arkansas," The History and Debates of the Convention of the People of Alabama (Atlanta, GA: Wood, Hanleiter, Rice \& Co., 1861): 443-444.

${ }^{54}$ Henry Rector to John Ross, January 29, 1861, Official Records, vol. 1, 683-684.

${ }^{55}$ Mark Bean, et. al. to John Ross, May 9, 1861, Annual Report of the Commissioner of Indian Affairs for the Year 1863 (Washington, D.C.: G.P.O., 1864), 232. 
locality \& natural sympathies are unequivocally with the slave holding States. And the contiguity of our Territory with your state, in connection with the daily social and commercial intercourse between our respective citizens forbids the idea, that they should ever be otherwise than Steadfast friends." To the concerned citizens of Boonsboro, Ross swore a "position of strict neutrality," hoping that "if my present position does not constitutes as 'active friends,' you will surely not regard us as an enemy." Chief John Ross was confounding Southerners with his hopeful neutrality, his adherence to Federal treaties alongside sincere promises of friendship. ${ }^{56}$

Leaving Fort Smith for Tahlequah in Cherokee Nation, Commissioner Albert Pike and Brigadier General McCulloch received a similarly elusive treatment at the hands of the Cherokee chief. Ross claimed "his intention was to maintain the neutrality of his people; that they were a small and weak people, and would be ruined and destroyed if they engaged in the war; and that it would be a cruel thing if we were to engage him in our quarrel." Frustrated, Pike reported that "We used every argument in our power to change his determination, but in vain." Making little headway, General McCulloch promised to adhere to Cherokee neutrality. Pike prophesied that neutrality would prove impossible and vowed to return at a later date. He then ventured west to North Fork Town in Creek Nation, hoping to find better luck among the other Five Tribes. ${ }^{57}$

The chiefs gathered in the large hall, anxious for the political battle that lay ahead. Although many tribal leaders were present, many others were missing. Too few were present to hold a full National Council, but the gathering was still impressive. Lending to the gravity of the meeting was the weight of its topic. It was February 12, 1825, and the leaders of the Creek

${ }^{56}$ John Ross to Henry M. Rector, February 22, 1861, and John Ross to Mark Bean, et. al, May 18, 1861, John Ross, The Papers of Chief John Ross, ed. Gary Moulton, vol. 2 (Norman: University of Oklahoma Press, 1985), 464-465, 470-471. All references refer to volume to unless otherwise noted.

${ }^{57}$ Albert Pike to D.N. Cooley, February 17, 1866, The Cherokee Question, 23-28. 
Nation arrived at Indian Springs in central Georgia to decide the future of their tribe. The issue was an old one, one that countless tribes faced across the American centuries: the encroachment of white settlers and the possibility of removal.

The Creeks had long been divided along geographical lines: Lower Creeks, who lived along the Chattahoochee River, and Upper Creeks, whose towns dotted the Coosa River Valley to the north. Although united into a single Creek Nation, significant cultural and political divides had developed among the Upper and Lower Creeks. While Lower Creeks embraced economic and social relationships with white neighbors, the Upper Creeks proved more resistant to white encroachment and assimilation. Both factions, however, participated in a colonial deerskin trade that ultimately gutted Creek culture and made the Creeks dependent upon Euro-American trade. These economic and cultural crises were sharpened by the disastrous Creek War of 1813-1814, when millenarian Upper Creeks revolted against the United States. The conflict proved disastrous; a bloody civil war finally crushed by Andrew Jackson's army at the Battle of Horseshoe Bend. Fighting alongside Jackson had been a contingent of Lower Creeks. ${ }^{58}$ The divide between the Lower and Upper Creeks was starkly apparent at the Indian Springs meeting. The particular issue at hand was a treaty drafted by the Federal government that would cede all Creek lands in Georgia and most of their holdings in Alabama to the United

\footnotetext{
${ }^{58}$ The field of pre-removal Creek scholarship is rich, and it unpacks many of the economic, cultural, and political struggles of the Creek Nation. Kathryn Braund's Deerskins and Duffels: The Creek Trade with AngloAmerica (1993) explores the destructive importance of the deerskin trade among the Creeks throughout the eighteenth century, which eroded their economy and made them increasingly reliant upon Euro-American goods. Joel Martin's Sacred Revolt (1991) emphasizes Creek intra-tribal millenarianism that encouraged Creeks (especially Upper Creeks) to rebel against white encroachment and assimilation in 1813. The pressures of acculturation among the Creeks have been explored by both Claudio Saunt and Andrew Frank. Saunt's New Order of Things: Property, Power, and the Transformation of the Creek Indians (1999) examines Creek "mestizos," (the children of Creek women and European men) arguing that these men transformed a loose Creek confederation into a true Creek Nation, albeit by embracing European concepts of property and wealth at the expense of Creek communalism. Conversely, Andrew Frank's Creeks and Southerners (2005) contends that Creeks were traditionally an inclusive people, and that Creeks of mixed heritage viewed themselves as both Creeks and Europeans and bridged the gap between those societies.
} 
States. In exchange, the Creeks would receive land west of the Mississippi, along with a substantial cash payment. The dual Creek factions were split on the issue, and on this cold February day, the respective champions of both camps would speak to the headmen of the entire tribe. Also present were Federal commissioners from Georgia and two Cherokee chiefs, John Ross and Major Ridge. ${ }^{59}$

The first to speak was Chief William McIntosh. A deeply respected Lower Creek leader who fought alongside Andrew Jackson at Horseshoe Bend, McIntosh believed that removal was inevitable. Better to make the transition now with favorable terms, than to needlessly delay removal. "This mighty nation has become dwarfed," McIntosh declared, "and it will only be a matter of time when there will be no game in the country, and they will be without food." The future of the tribe lay to the west, McIntosh reasoned. "Beyond the Great River is the bright sun and the sky as blue and the water as sweet as they are here. Our people will go with us. To love the ground is mean; to love the people is noble." Speaking for nearly two hours, McIntosh's speech seemed to strike a chord with the listeners, who then turned to hear the words of the opposing speaker that day. ${ }^{60}$

A young warrior just in his late twenties, Opothleyahola rose in response to McIntosh's words. Despite his age, the Upper Creek leader enjoyed a growing place of prominence within the Creek Nation. Having fought alongside the Red Sticks against Andrew Jackson and William McIntosh at Horseshoe Bend, Opothleyahola swore never again to raise arms against the United States. Although he may have disavowed rebellion, he was wary of ceding more land to the Americans. Speaking on behalf of himself and other Upper Creek leaders, Opothleyahola made

59 Angie Debo, The Road to Disappearance: A History of the Creek Indians (1941, repr., Norman: University of Oklahoma Press, 1987), 88-91; George Chapman, Chief William McIntosh: A Man of Two Worlds (Atlanta, GA: Cherokee Publishing, 1988), 75-76.

${ }^{60}$ Chapman, Chief William McIntosh, 75-76. 
his views clear. "I am induced to believe that it may be best for us to remove, but we must have time to think of it; and, should the chiefs who are here sell the land now, it might create dissensions and ill blood among the Indians." Opothleyahola's fervent speech was a bid for time and a bid for unity. To sign the treaty now, without the full approval of the Creek National Council, was unthinkable. In a terse final warning, Opothleyahola addressed William McIntosh directly, "I have told you your fate if you sign that paper. I once more say, beware."61

Despite Opothleyahola's plea and the absence of a number of Creek leaders and delegations, William McIntosh and dozens of others signed the Treaty of Indian Springs. Though clearly fraudulent and ultimately renegotiated, the Treaty of Indian Springs planted profoundly bitter seeds among the Creek Nation. Though handsomely rewarded with $\$ 40,000$ for his part in signing the treaty, William McIntosh paid dearly within a few short months. By ceding tribal land without the tribal government's permission, McIntosh violated Creek law. On May 30, 1825, several hundred Creek warriors surrounded McIntosh's home on the Chattahoochee River, war-whoops filling the air. The house was set ablaze. Women, children, and white persons in the house were allowed to exit. Susannah McIntosh begged for her husband's life in the yard, to no avail. The leader in charge of the party cried out, "McIntosh, we have come. We have come. We told you if you sold the land to the government, we would come." Upon Williams McIntosh's appearance at the doorway, he was riddled with bullets. His body was scalped. William's son Chilly McIntosh and his comrade Moty Kennard escaped through a window, swimming across

${ }^{61}$ Lela J. McBride, Opothleyaholo and the Loyal Muskogee: Their Flight to Kansas in the Civil War (Jefferson, NC: McFarland, 2000), 34-42; Chapman, Chief William McIntosh, 75-78. Lela McBride's work offers one of the few detailed treatments of Opothleyahola. Despite the title, her work is actually a brief survey of Opothleyahola's entire life. While the book provides many details on Opothleyahola not found elsewhere, it is somewhat limited by its near exclusive reliance upon government publications. 
the nearby Chattahoochee to safety. Although his involvement is unclear, rumors nevertheless swirled that Opothleyahola helped orchestrate the assassination. ${ }^{62}$

The death of William McIntosh did not deter removal; Creeks migrated west for several years before Andrew Jackson forced final removal upon the Creeks in 1832. Yet the fraudulent circumstances of the Treaty of Indian Springs and the assassination of William McIntosh sowed deep divisions that simmered for decades among the Creek tribe. These divisions — and old feuds between Opothleyahola and the McIntsohes — were not forgotten on the eve the Civil War. Even slaves knew of the rivalry. Nellie Johnson, an African Creek enslaved by Roley McIntosh (one of William's brothers), recalled that “old Master's pappy [William] was killed by the Creeks because he signed up a treaty to bring his folks out here, and old Master [Roley] always hated that bunch of Creeks...I think old man Gouge [Opothleyahola] was one of the big men in that bunch." The political feuds over removal, the factional divide between the Upper and Lower Creeks, and the deadly rivalry between Opothleyahola and the McIntosh profoundly shaped the negotiations of the Confederate-Creek alliance in $1861 .^{63}$

In June of 1861, as the Confederacy formed and the Chickasaws and Choctaws were drawn into Confederate orbit and the Cherokees clung to neutrality, a delegation of Creek, Seminole, and Cherokee leaders set out across the rolling prairies of northern Indian Territory. Included among the band was prominent Upper Creek leader Oktaharsharjo. Backing the

\footnotetext{
${ }^{62}$ McBride, Opothleyaholo, 38-47; Chapman, Chief William McIntosh, 78-89.

${ }^{63}$ T. Lindsay and Julie P. Baker, eds., "Nellie Johnson," The WPA Oklahoma Slave Narratives (Norman: University of Oklahoma Press, 1996), 225.
} 
enterprise was Cherokee Chief John Ross, who desperately wanted to maintain Indian neutrality and unity as war loomed on the horizon. ${ }^{64}$

Heading west, the party made their way to Antelope Hills. Rising among the plains, the low-lying Antelope Hills are situated along the Canadian River near the Texas panhandle. The hills were a well-known location deep within western Indian Territory, where nomadic Plains tribes ruled the vast, open landscape. Over the course of the several days, the delegates from eastern Indian Territory conferred with their counterparts from the western half, including Anadarko, Caddo, Comanche, Delaware, Kickapoo, Tonkawa, Wichita, and others. Although relatively little is known about the conference proceedings, the general goal was to encourage all of the tribes - east and west — to remain neutral and unified in the coming days. The meeting apparently went well, and the delegates departed and made their way home. ${ }^{65}$

While these delegates were away, promoting the cause of peace and Indian cooperation, Albert Pike made his way from Tahlequah to North Fork Town, the capital of Creek Nation. Pike's timing was not fortuitous; it was planned. The clever Arkansan understood perfectly well that with so many Indians in favor of neutrality away on business, the Confederacy possessed a perfect opportunity to negotiate with friendly members of the Creek and Seminole tribes. As Pike himself bragged about the pro-neutrality Indians, "I defeated all that by treating with the Creeks at the very time that their delegates were at the Antelope Hills in council."66

With prominent Upper Creek leaders absent, Albert Pike found sympathetic ears at North Fork Town. Gathered there were not only many Lower Creek leaders but also the Chickasaws

${ }^{64}$ Grant Foreman, A History of Oklahoma (1942, repr., Norman: University of Oklahoma Press, 1945),103. Foreman suggests that Opothleyahola made the journey to Antelope Hills. If true, it would be a significant indicator that Opothleyahola backed neutrality from an early date. Foreman's dated work, however, doesn't indicate where his information regarding the Antelope Hills conference originated, and there's little other evidence to suggest Opothleyahola's presence.

${ }^{65}$ Foreman, History of Oklahoma, 103.

${ }^{66}$ Albert Pike to D.N.Cooley, February 17, 1866, The Cherokee Question, 24. 
and Choctaws, who had already renounced their treaties to the United States and pledged loyalty to the Confederacy but still needed to negotiate a formal treaty. Pike treated with the Chickasaws and Choctaws first, a relatively quick affair given their prior proclamations. The Confederate commissioner then sat in council with the Creeks present, working to forge a Confederate-Creek alliance.

The wealthy, slaveholding Creeks negotiating with Pike envisioned themselves as not only Creeks, but also as Southerners. They firmly believed their material interests to be intertwined with those of the Southern Confederacy. Captain Charles Bruslé, assigned to accompany Pike throughout Indian Territory, was struck by the cultured air and Southern patriotism of the Creeks he encountered. "These gentlemen show the very smallest evidence of Indian blood, are very affable, courteous and polite in manners," Bruslé noted. "One would imagine he was among the most refined of the American race, did he not know them to be halfbreeds. They are similar in dress to the Americans, and intensely Southern in feeling and sentiments. They despise a Yankee as they would a rattlesnake, with all that deadly hatred so characteristic of the race." 67

With political opposition absent, Pike had little difficulty treating with the prosecessionist Indians present; discussions for a Confederate-Creek treaty of alliance were soon underway. The treaties Albert Pike negotiated with the Chickasaws, Choctaws, and Creeks at North Fork Town were exceptionally generous. Pike had been given a wide degree of discretion in negotiations, and he determined to give the Indians plenty of guarantees, "formal, full, and

${ }^{67}$ W.H. Tunnard, A Southern Record: The History of the Third Regiment Louisiana History (Baton Rouge, LA, 1866), 98-102. It is perhaps telling that Bruslé saw no full-bloods during his visit to North Fork Town, only encountering a few later in his travels. He reported them "exceedingly lazy and slovenly, a thousand times more so than negroes...The majority of them speak no English, and exhibit no disposition to be on friendly terms with the whites. They are the most independent people in the world." Brusle's commentary highlights the sharp cultural distinctions between "mixed-bloods" and "full-bloods," and the general absence of full-bloods during his travels hints at their lack of involvement and apathy to Confederate-Creek negotiations. 
ample, by treaty, if the Indians will accept them and make treaties." The Confederacy promised to assume all the annuities owed by the Federal government to the Indians. The tribes would retain sovereignty of their respective nations, including judicial sovereignty and the ability to restrict the settlement of non-tribal citizens. Native Americans were granted full citizenship within the Confederacy. The treaties expressly preserved the institution of slavery. Particularly substantial were promises of representation in Confederate Congress, and a legitimate path to statehood should they choose. From a military perspective, the Confederacy promised to defend Indian Territory and would bear the expense of its defense alone. In return, the Choctaw and Chickasaws would raise a mounted regiment for Confederate service; the Creeks would likewise raise another. These regiments would be led by Indian officers, equipped and paid (the same wages as white men) by the Confederacy. ${ }^{68}$

Imbued with Southern sympathies, welcoming of Southern culture, invested in the institution of slavery, and presented with deeply favorable treaty terms — which one historian declared "more favorable to the Creeks than any treaty they ever made with the United States"the Creeks present at North Fork Town assented to the treaty. However favorable the terms, , the treaty still required ratification by the Creek National Council, which meant the treaty needed to be presented to Upper Creek leaders. When Oktaharsharjo and other Upper Creeks returned from their Antelope Hills expedition, they were stunned to find a treaty with the Confederacy had already been negotiated and drawn up, merely awaiting their signatures. The Upper Creeks balked. Despite Albert Pike's best efforts, Oktaharsharjo and other recalcitrant Creeks remained steadfast in opposition. As one Creek remembered, "They already had a treaty with the United

68 Albert Pike to Robert Toombs, May 20, 1861, Official Records 3, 580-581; Albert Pike to R.W. Johnson, May 11, 1861, Official Records 3, 572-574. 
States, which was good enough for our safety, and that we should call upon our great Great Father for protection, which had been granted us in our former treaties."69

Unwilling to sign the treaty, the opposition Creeks walked out of the Council proceedings. Despite the walkout, the remaining members of the Creek National Council signed the final treaty anyways, sealing the Confederate Creek alliance on July 20. Among the signees was Chilly McIntosh, the son of long-dead Chilly McIntosh, and Moty Kennard; these two had together escaped William McIntosh's burning house on the Chattahoochee over three decades prior. Kennard was now the principal chief of the Lower Creeks. Also signing was the principal chief of the Upper Creeks Echo Harjo, one of the few Upper Creeks to support the Confederate treaty. The signatures of three Creeks who walked out in opposition, including Oktaharsharjo, were fraudulently affixed to the treaty as well. Within the month, a mounted regiment of Creek soldiers was mustered into Confederate service, and Daniel McIntosh—youngest son of assassinated William McIntosh—was elected its colonel. ${ }^{70}$

Also in opposition to the Confederate-Creek treaty was old Opothleyahola, who had once risen to speak out against a fraudulent treaty with the United States. Now in his sixties, Opothleyahola no longer held any official position within the Creek government, yet he remained a deeply respected and powerfully influential figure within Creek Nation. It is not clear just when Opothleyahola decided to oppose the Confederate treaty. Some reports suggest he was present at North Fork throughout the negotiations and approved of the alliance, only to later change his mind. Other accounts indicate he opposed the treaty from the start. Regardless of

${ }^{69}$ Abel, The American Indian as Slaveholder and Secessionist, 191-194; Debo, Road to Disappearance, 145-146; Statement of Creek delegation, September 12, 1865, Annual Report for the Commissioner of Indian Affairs $1865,328$.

${ }^{70}$ Statement of Creek delegation, September 12, 1865, Annual Report for the Commissioner of Indian Affairs 1865, 328. 
exactly when Opothleyahola chose sides, it is clear that his bitter history with the McIntosh

family played a key role in his decision. ${ }^{71}$

Years later, Albert Pike would scorn that 'Ho-poi-ilth-thli-Yahola was not 'loyal.' He feared the McIntoshes, who had raised troops, and who he thought meant to kill him for killing their father long years before." Other Creeks likewise recalled that Opothleyahola "for reasons entirely of a domestic character and in no wise [sic] connection with the National question at issue, withdrew from the country and assumed a hostile attitude." The influence of the McIntosh clan in securing the Confederate-Creek alliance, and perhaps the election of Daniel McIntosh to command of the $1^{\text {st }}$ Creek Mounted Volunteers, helped propel Opothleyahola into the opposition camp. With old rivalries not forgotten, and perhaps fearful of the McIntosh's newfound power, Opothleyahola played an increasingly large role among Creek opposition in the days ahead. ${ }^{72}$ For Oktaharsharjo, Opothleyahola, and many other Creeks, the Confederate-Creek treaty of 1861 must have been reminiscent of the fraudulent 1825 Treaty of Indian Springs. Once again, a treaty with a foreign power had been signed without the consent of the full National Council.

${ }^{71}$ Albert Pike to D.N. Cooley, February 17, 1866, The Cherokee Question, 23-28; Creek delegation, quoted in Annie H. Abel, American Indian as Slaveholder and Secessionist, 362n. In an 1866 report to the United States Commissioner of Indian Affairs, Albert Pike claimed that after his failed May meeting with John Ross, Ross "persuaded Opotheyaholo, the Creek leader, not to join the Southern states, and had sent delegates to meet the northern and other Indians in council near the Antelope Hills, where they all agreed to be neutral." Pike's statement suggests that Opothleyahola was likely in the neutral camp prior to negotiations at North Fork Town. In the same report, Pike then later states that Opothleyahola wasn't loyal to the U.S., but only fearful of the McIntoshes, and that "If Mr. Ross had treated with us at first, the Creeks would have done the same." Overall, Pike's comments suggest John Ross' manipulations and fears of the McIntoshes kept Opothleyahola from supporting the Confederacy. It's worth noting that Pike makes no mention of Opothleyahola being present during negotiations at North Fork Town. However, a committee of Creeks claimed after the war that Opothleyahola "was however present at the making of said Treaty and give said Pike to understand that he fully concurred in the result of our deliberations." This statement comes from a document transcribed fully in a footnote of Annie Heloise Abel's American Indian as Slaveholder and Secessionist (1915). As with a number of Abel's footnotes, her citations have not aged well. The National Archives has reorganized its files on Indian Affairs, making it difficult to retrace her footsteps and find her sources. Without greater context for the document, it's difficult to place too much veracity in its account, especially since it seems to have been written by former Confederate Creeks. Overall, it seems probable that Opothleyahola possessed reservations about the treaty throughout the negotiation process, and publicly opposed the treaty sometime after Oktaharsharjo and other dissident Creeks walked out of the treaty proceedings.

72 Albert Pike to D.N. Cooley, February 17, 1866, The Cherokee Question, 23-28; Creek delegation, quoted in Annie H. Abel, American Indian as Slaveholder and Secessionist, 362n. 
Once again, the McIntosh family stood at the center of such fraudulence. In negotiating with the Creek Nation, Albert Pike drew upon a long tradition of deceitful diplomatic tactics utilized by whites to garner concessions from Native Americans. Yet in 1861, these fraudulent tactics would not be met with legal dissent, but instead by political mobilization and eventually violence.

On August 5, those Creeks who opposed the Confederate alliance — the "Loyal Creeks"met in council and declared the treaty void. ${ }^{73}$ They elected Sands their principal chief, but over the next few weeks it became clear that Opothleyahola would be the movement's leader. On August 15, Sands and Opothleyahola wrote President Abraham Lincoln a letter:

Now I write to the President our Great Father who removed us to our present homes, \& made a treaty, and you said that in our home we should be defended from all interference from any people and that now white people in the whole world should ever molest unless the come from the sky but the land should be ours as long as grass grew and waters run, and should we be injured by anybody you would come with your soldiers \& punish them, but now the wolf has come, men who are strangers tread our soil our children are frightened $\&$ the mothers cannot sleep for fear.

I was at Washington when you treated with us, and now White People are trying to take our people away to fight against us and you. I am alive. I well remember the treaty. My ears are open $\&$ my memory is good. ${ }^{74}$

By rejecting the authority of the Creek National Council and the Confederate-Creek treaty, electing Oktaharsharjo chief, and appealing to the Federal government for help, the Loyal

${ }^{73}$ The term "Loyal Creeks" and "Loyal Indians" has been utilized by several historians. Though not ideal, the term adequately reflects the idea that Oktaharsharjo, Opothleyahola, and their followers wished to remain loyal to their existing treaties with the Federal government.

${ }^{74}$ McBride, Opothleyaholo and the Loyal Muscogee, 150. While most of Opothleyahola's followers were Upper Creeks, some Lower Creeks did dot his ranks. The term "Loyal Creeks" has been used by historians previously, and I use it here as an umbrella term to describe all of Opothleyahola's followers. While technically Opothleyahola, Sands, and others did advocate continued adherence to existing Federal treaties (they were "loyal"), it's important to note that they did not rebel against Confederate authority out of any desire to preserve or protect the Union. They remained loyal to the U.S. for their own internal reasons, as this paper discusses. 
Creeks drew a line in the sand, sowing the seeds for greater intra-tribal conflict. Their actions were born out of the fraudulent diplomatic tactics of Albert Pike and his Lower Creek allies, and out of the feuds and fear that existed between Opothleyahola and the McIntosh family.

Having inked treaties with the Chickasaws, Choctaws, and Creeks, Albert Pike rode further west to Creek Agency to meet with the Seminoles. Numbering only a few thousand souls, the Seminoles were the smallest of the Five Tribes. They were also the last to remove westward, having fought several fierce wars of resistance against the United States in the Everglades of their ancestral Florida home. Only by the early 1840s had most of the Seminole been finally, forcefully removed to Indian Territory, where they settled to the west of the Creek Indians with whom they were culturally and linguistically related. Given their fierce resistance to outside influence and removal, the Seminoles were also the least acculturated of the Five Tribes, although nearly one thousand slaves inhabited their nation. ${ }^{75}$

Conservative and wary of white men and their institutions, the Seminoles were disinclined to ally with the Confederacy from the start. In March, they had spurned overtures by Choctaws and Chickasaws to prepare for the Union's dissolution and ally with the South. The occupation of Forts Arbuckle, Cobb, and Washita further left the Seminoles uneasy as to Southern intentions. As with the other Five Tribes, the Federal government's agents to the Seminoles proved to be ardent secessionists. Josiah Washburne, the Seminole agent from 18531857, and Samuel Rutherford, their agent until 1860, both worked to convince the Seminoles

\footnotetext{
75 John K. Mahon, History of the Second Seminole War, 1835-1842 (1967, repr., Gainesville: University of Florida Press, 1985), 321; Michael F. Doran, "Population Statistics of Nineteenth-Century Indian Territory," Chronicles of Oklahoma 53, no. 4 (1975), 498-501. John Mahon's History of the Second Seminole War, 1835-1842 offers a fine overview of Seminole resistance prior to removal. Mahon notes that approximately 3,800 Seminoles were in Indian Territory by 1843. Michael Doran places the Seminole Nation's size at approximately 2,630 by 1860 (not including approximately 1,000 slaves), indicating that the Seminole population suffered a decline in the years since removal.
} 
their fate was intertwined with the Confederacy. They emphasized the shared institution of slaveholding and warned that the United States' dissolution was assured. Europe would intervene on the South's behalf, and as the Union splintered, the Federal government would be unable to pay the Seminoles their annuities. ${ }^{76}$

When Albert Pike sent word he desired to meet the Seminoles at the Creek Agency, his message was accompanied by a letter vouching for the Confederate cause written by former agent Josiah Washburne. Unfortunately for Pike, however, the Seminoles had another source of information: U.S. Indian agent Edwin H. Carruth. Perhaps one of the only Federal authorities in contact with the Five Tribes during the summer, Carruth actually met with Seminole Chief John Jumper and several other Seminole chiefs shortly after Albert Pike's request for a meeting arrived. The loyal Union agent spent the day helping the Seminole leaders understand the true political situation. "None were more eager for information than the Seminoles," Carruth reported, "and they well understood the fact that should the south fail in her rebellion, the seceding tribes would forfeit lands, annuities, and be liable to punishment." Carruth read newspaper reports to the chiefs, pulled out a map of the United States to explore the geopolitical situation, and generally did his best to dissuade the Seminoles from joining the Confederacy.

${ }^{76}$ E.H. Carruth to David Hunter, November 26, 1861, Annual Report of the Commissioner of Indian Affairs for the Year 1861 (Washington, D.C.: G.P.O., 1862), 46-49 (the print edition lists the author as "C.H. Carruth," but this is likely a typo, and the author was probably the well-known Indian agent Edwin H. Carruth); Edwin C. Reynolds, The Seminoles (Norman: University of Oklahoma Press, 1957), 291-292; Thomas Elton Brown, "Seminole Indian Agents, 1842-1874," Chronicles of Oklahoma 51, no. 1 (1973), 69-75. Edwin Reynolds' dated work offers a solid overview of Seminole history, though his majority of his book focuses on the pre-removal era; his chapters on the Civil War and post-war years are slim. Jane Lancaster's Removal Aftershock: The Seminole's Struggles to Survive in the West, 1836-1866 (Knoxville: University of Tennessee Press, 1994) provides a more indepth examination of the traumatic events of the mid- $19^{\text {th }}$ century, and she gives probably the most detailed survey of the Seminoles in the Civil War available. For more on post-removal Seminole history, see Jerry L. Burk, "Oklahoma Seminole Indians: Origin, History, and Pan-Indianism," Chronicles of Oklahoma, 51, no. 2 (1973), 211223 and Edward L. Carter, "The Seminole Nation after Leaving Florida, 1855-1860," Chronicles of Oklahoma 55, no. 4 (1977), 133-453. The unique experiences of African-American Seminoles are explored in Daniel F. Littlefield, Jr.'s African and Seminoles: From Removal to Emancipation (1977, repr., Jackson: University Press of Mississippi, 2001). 
"Not a man among them at that time was in favor of going with the south...Jumper left with the four men he had selected for the Creek agency, to see Captain Pike, with, I believe, the honest intention of being true to the government," Carruth stated. ${ }^{77}$

The next day, Chief John Jumper and the Seminole delegation departed for the Creek Agency. Tall, well-built, and possessing, as one onlooker thought, a "dark expressive countenance, serious...a semi-savage and imposing look," Jumper was a full-blood Seminole who spoke no English. Yet he was anxious to see the Seminoles embrace American culture. In the past few years, he had pushed for more missionary schools, the embrace of Christianity, and the banning of alcohol among his tribe. Though perhaps disinclined to break with Seminole treaties with the United States, he would listen to what Albert Pike had to say. ${ }^{78}$

Pike hoped that by meeting the Seminoles at the Creek Agency within Creek Nation, he could draw upon the influence of the newly-minted Confederate-Creek alliance to sway Seminole minds. The plan backfired. Although Pike apparently made some headway with John Jumper and several others, word soon spread to the Seminoles of the fraudulent circumstances regarding the Creek treaty, and that many Upper Creeks had walked out of council proceedings. Several Seminoles departed the Creek agency, but Jumper and several others remained with Pike and began planning for the negotiation of a Confederate-Seminole alliance. Pike was offering Jumper and the Seminoles generous treaty terms similar to those received by the Creeks and others. Jumper was swayed, but the tribe needed convincing. ${ }^{79}$

${ }^{77}$ E.H. Carruth to David Hunter, November 26, 1861, Commissioner of Indian Affairs 1861, 47; Lancaster, Removal Aftershock, 133.

${ }^{78}$ E.H. Carruth to David Hunter, November 26, 1861, Commissioner of Indian Affairs 1861, 47; Letter to editor, Northern Standard [Clarksville, TX], May 2, 1863; Lancaster, Removal Aftershock, 118-119, 133.

${ }^{79}$ Lancaster, Removal Aftershock, 133-134. 
Moving directly into Seminole Nation, Pike again met with Seminole leaders. Once again, Pike's pitch apparently met with mixed results. Although Jumper was now supportive of a Confederate alliance, many other Seminoles were not. They desired to remain true to existing Federal treaties. Undoubtedly, their recent discussion of national affairs with Edwin Carruth also helped immunize them against Pike's claims that the Federals would invade Seminole Nation. Despite Seminole disunity, however, John Jumper and several others signed a treaty of alliance with the Confederates. Once again, Pike convinced a tribal minority to sign an alliance against the wishes of many Indians. Edwin Carruth believed John Jumper had been bribed, and further noted that while Jumper "felt true to the [Federal] treaties...the Forts west were in possession of its enemies, their Agent would give them no information on the subject, \& he feared that his country would be overrun, if he did not yield." $\$ 80$

Just as Albert Pike's dishonest diplomacy had fractured the Creek tribe, a number of prominent Seminole leaders quickly revolted against the fraudulent Confederate-Seminole treaty, including Halleck Tustenuggee, Billy Bowlegs, John Chupko, and Pascofar. These men soon led several hundred Seminole followers to join the dissident Creeks under Oktaharsharjo and Opothleyahola in their growing political rebellion against the Confederacy. ${ }^{81}$

While Opothleyahola, Oktaharsharjo, and thousands of Creeks and Seminoles rejected Confederate overtures, John Ross and the Cherokee Nation finally succumbed. The catalyst for changed proved to be Stand Watie, Ross' old rival. Watie and other members of the Treaty Party desired an alliance with the Confederacy and chafed under Ross' policy of neutrality, which they

${ }^{80}$ E.H. Carruth to David Hunter, November 26, 1861, Commissioner of Indian Affairs 1861, 47; Lancaster, Removal Aftershock, 133-137.

${ }^{81}$ Annual Report of the Commissioner of Indian Affairs for the Year 1865 (Washington, D.C.: G.P.O., 1866), 332-333; Lancaster, Removal Aftershock, 133-137. 
believed "tied up our hands \& shut our mouths \& put the destiny \& everything connected with the Nation \& our lives \&c in the hands of the Executive." Watie and his followers worried that Ross wielded too much power. ${ }^{82}$

Stand Watie worked diligently to undermine neutrality and pull his nation into a Confederate alliance. In this endeavor, he was not alone. In May, citizens of Fayetteville, Arkansas reached out to Watie "urging you, as a private and public citizen of the Cherokee Nation, to join us in our efforts for mutual defence [sic].” The Arkansans promised they could deliver guns and ammunition to Watie "for the use of the Cherokees in the defense of their and our frontier.” In mid-July, despite John Ross' proclamation of neutrality, Brigadier General Benjamin McCulloch commissioned Stand Watie a Confederate colonel and authorized Watie to raise troops. Although Watie himself wasn't present, a small number of Cherokees fought alongside Benjamin McCulloch's Confederate forces in their August victory at Wilson's Creek in southwestern Missouri. ${ }^{83}$

Attuned as ever to Cherokee politics, John Ross sensed the political ground shifting under his feet. With Watie and his followers flouting neutrality, the Cherokee Nation was at risk of being torn apart by competing factions and pulled into the war anyway. Moreover, Confederate victories at First Manassas and Wilson's Creek loomed large; the Confederacy seemed to be winning the Civil War. Finally, as summer shifted into fall, John Ross became keenly aware of the Cherokees' precarious position as the only tribe in Indian Territory still clinging neutrality.

${ }^{82}$ William P. Adair and James M. Bell to Stand Watie, August 29, 1861, Cherokee Cavaliers: Forty Years of Cherokee History as Told in the Correspondence of the Ridge-Watie-Boudinot Family, Edward Everett Dale and Gaston Litton, eds. (1939, repr., Norman: University of Oklahoma Press, 1995), 108-109; Kenny A. Franks, Stand Watie and the Agony of the Cherokee Nation (Memphis: Memphis State University Press, 1979), 117.

${ }^{83}$ A.M. Wilson and J.W. Washbourne to Stand Watie, May 18, 1861, Cherokee Cavaliers, 106-107; Benjamin McCulloch to John Ross, September 1, 1861, Official Records 3, 690-691; Benjamin McCulloch to John Drew, September 1, 1861, Official Records 3, 691; Franks, Stand Watie, 117-118; William Garrett Piston and Richard W. Hatcher III, Wilson's Creek: The Second Battle of the Civil War and the Men Who Fought It (Chapel Hill: University of North Carolina Press, 2000): 92. 
Always a believer in Indian unity, worried over the increasing influence of his political rival in Watie, and acknowledging the geopolitical reality of his situation, John Ross finally acceded to a Confederate alliance.

On August 21, Chief John Ross addressed nearly 4,000 Cherokees who gathered in Tahlequah, "the largest known [meeting] among this people for many years." Ross began by noting "that evil times have befallen the great Government with which we have been connected." Acknowledging internal divisions within his nation, the chief urged the Cherokees to remain unified, asking "whether you are arrayed in classes one against the other - the full-blood against the white and mixed blood citizens - say whether you are faithful to the constitution and laws of your country? whether you abide by all the rights they guarantee, particularly including that of slavery?" 84

Having appealed for unity, Ross laid his case bare. "The permanent disruption of the United States into two governments is now probable. The State [Arkansas] on our border and the Indian Nations about us have severed their connection from the United States and joined the Confederate States. Our general interest is inseparable from theirs and it is not desirable that we should stand alone." Reversing course on neutrality, Ross now asked the people to "signify your consent...for an alliance with the Confederate States upon terms honorable and advantageous to the Cherokee Nation.” Ross sent a courier to Albert Pike, asking him to return to Cherokee Nation to negotiate a treaty. ${ }^{85}$

${ }^{84}$ John Ross, “Address to the Cherokees," August 21, 1861, Papers of Chief John Ross 2, 479-481; "Mass Meeting in the Cherokee Nation," Dallas Herald, September 11, 1861.

${ }^{85}$ John Ross, “Address to the Cherokees," August 21, 1861, Papers of Chief John Ross 2, 479-481; Albert Pike to Dennis N. Cooley, February 17, 1866, "The Cherokee Question. Report of the Commissioner of Indian Affairs to the President of the United States," (Washington, D.C.: Government Printing Office, 1866), 24. 
On September 25, the Cherokee Nation once again gathered in Tahlequah. Albert Pike and John Ross had agreed to the terms, identical to those offered the other Five Tribes, and Pike was pleased that Ross had come around. "I not more doubted then that Mr. Ross' whole heart was with the South than that mine was," Pike reflected. The time had come to sign the treaty, and many were on hand to observe the ceremony. ${ }^{86}$

Besides for the thousands of civilian onlookers, two Confederate Cherokee regiments oversaw the day's events. Col. Stand Watie stood by, with 80 or 90 of his devoted followers alongside. Yet Watie's outfit was dwarfed by the nearly 900 new recruits of Colonel John Drew's Cherokee regiment. The nephew of John Ross, John Drew and the other officers of his regiment were firmly loyal to the Ross faction, and the rank and file of the regiment were comprised of full-blood, traditional Cherokees (many of whom belonged to the Keetowah Society). The creation of Drew's regiment—a unit essentially loyal to John Ross first and foremost—indicated that despite joining the Confederacy, Chief Ross had no intention of losing influence or power to rival Stand Watie. ${ }^{87}$

With the two lopsided Cherokee regiments present, speeches were made, and Albert Pike presented John Drew's regiment with a Confederate flag; Ross “exhorted them to be true to it." Then John Ross and Stand Watie, in a rare moment of reconciliation, shook hands. Ross “expressed his warm desire for union and the harmony of the nation." Watie responded acerbically "that there now existed a party in the nation known as the pin party, and as long as they held their political organization there could be no peace." Watie, perhaps frustrated that

${ }^{86}$ Albert Pike to Dennis N. Cooley, February 17, 1866, "The Cherokee Question," 24; "The Cherokees," The Standard [Clarksville, TX], October 26, 1861.

${ }^{87}$ Albert Pike to Dennis N. Cooley, February 17, 1866, "The Cherokee Question," 24; "The Cherokees," The Standard [Clarksville, TX], October 26, 1861; W. Craig Gaines, The Confederate Cherokees: John Drew's Regiment of Mounted Rifles (Baton Rouge: Louisiana State University Press, 1989), 15-16, 20-21. 
Ross outmaneuvered him again by creating John Drew's regiment, threatened to undue the civility of the moment by referencing the Keetowah Society and tribal divisions. Ross disavowed knowledge of the "Pin Party," however, and after a "little parley," the treaty was signed. The Cherokee Nation and Confederacy were allied, their fortunes linked. ${ }^{88}$

By September of 1861, all Five Tribes had joined their fates to the Confederacy via treaties of alliance. Enthusiasm for the Confederacy and the prospect of war ran high in certain circles, and by the end of the year nearly 3,600 Native Americans from these tribes would be clothed in Confederate gray. On paper, Albert Pike accomplished much that summer, forging alliances despite political opposition and securing Indian Territory for the would-be Confederate nation.

Yet these paper treaties masked the fraudulent diplomacy, deep political and cultural schisms, and mounting anti-Confederate resistance that lurked underneath the ConfederateIndian alliances. For many Native Americans, the Confederate alliances forged that summer represented yet another generation of fraudulent treaties made without the consent of the whole tribe. Among the Chickasaws and Choctaws, whatever support for neutrality that existed was snuffed out by Texan mobs and the machinations of wealthy, slaveholding tribal leaders. Among the Creeks and Seminoles, only brazenly unethical, illegal diplomatic maneuvers by both Albert Pike and willing Indian conspirators produced treaties with the Confederacy. Unsurprisingly, pro-neutrality and pro-Union elements mobilized quickly among these nations. The ConfederateIndian treaties would not stand unchallenged.

\footnotetext{
${ }^{88}$ Albert Pike to Dennis N. Cooley, February 17, 1866, "The Cherokee Question," 24; "The Cherokees," The Standard [Clarksville, TX], October 26, 1861.
} 


\section{"Now the Wolf Has Come": Opothleyahola's Rebellion, 1861}

"There is a disposition in some to scoff at the brave Muscogees, who marched northward with Opethlolehola, fighting as they went. When an impartial history shall be written, the wrapt prophet shall pause over the bloody ledges on the Red Fork of Arkansas, while the ghosts of martyred heroes murmer 'momen'”, -Cherokee Tomahawk, Fort Gibson, March 13, $1865^{89}$

Seven year-old Mary Perryman was frightened. The events of the past few days confused the young slave girl: the visits of strange Indians urging her family to run away, the secret conversations in the woods between her father Jacob and uncles William and Hector, the late night tears of her mother, the incessant cooking of food the children weren't allowed to eat.

Now this morning at sunrise her master Mr. Mose Perryman, a Creek Indian, came down to her family's cabin "waving a shot gun and hollering at the top of his voice." Mary later recalled that she "never saw a man so mad in all my life, before nor since!" This moment of fear was compounded by the realization that her father - and indeed all the enslaved men on the Perryman farm—-had disappeared. Her mother consoled her, 'Don't' you worry about your pappy, he's free now. Better be worrying about us. No telling where we all will end up!" Mose Perryman ordered his remaining slaves to pack their belongings, determined to "take all you black devils to a place where there won't no more of you ran away." Mary and her mother were sent south, farther from the turmoil wreaking havoc in Creek Nation in the summer of 1861 and causing slaves to escape. ${ }^{90}$

${ }^{89}$ Cherokee Tomahawk [Fort Gibson, Cherokee Nation], March 13, 1865.

${ }^{90}$ Baker, T. Lindsay and Julie P., eds., WPA Oklahoma Slave Narratives (Norman: University of Oklahoma Press, 1996): 171-178. Mose Perryman was Moses Perryman, who died in 1866. For more on the prominent Perryman family, see John Bartlett Meserve, "The Perrymans," Chronicles of Oklahoma 15, no. 2 (June, 1937): 166184. 
Around the same time that Mary's life upended, ten year-old James Scott, a Creek Indian himself, was equally perplexed by recent events. His family tasked him to round up the cattle, a seemingly routine chore that James quickly realized was anything but routine. "I wondered at the vast amount of cattle being killed and the meat being dried, the pork being cooked down, and all the other numerous preparations," James later remembered. "At all of the houses of the neighbors, I saw all sorts of preparations with little knowledge of its meaning." Only later would James understand why he and his family_mother Larney, father Artuss, and sister Lizzie — took part in the "stirring events and the flight of the Muskogee" in the summer and autumn of $1861 .{ }^{91}$

The fraudulence of the Confederate-Creek treaty negotiated in July bore bitter fruit for both the Creek Nation and the Confederate States. Beginning in August, Creek leaders began working to undermine the Confederate-Creek alliance and remain neutral in the looming civil war. Over the course of the autumn, their resistance to the Confederacy transformed from a political rebellion into a literal one, wherein thousands of Native Americans and runaway slaves left their homes and formed a motley army under the command of Creek chief Opothleyahola in rejection of their tribal governments and the Confederacy.

Opothleyahola's Rebellion constituted both a major pan-Indian rebellion against the Confederacy. Thousands of Creek, Seminoles, and Cherokees - along with smaller parties from another dozen tribes - joined Opothleyahola in dissent. Their rebellion signified resistance to wealthy, acculturated tribal elites who sought to forge links to the Confederacy; it was resistance to yet another series of fraudulent treaties reminiscent of removal, but this time, Natives would not acquiesce. Beyond an Indian rebellion, however, it was also a slave revolt, the largest of the American Civil War. Nearly 500 African-Americans, most of them runaway slaves, joined

\footnotetext{
91 “Interview with James Scott,” March 29, 1937. IPP, WHC, OU.
} 
Opothleyahola's army, using the rebellion as an avenue towards freedom. This rebellion, then, marks a moment of great agency for both traditionalist Natives and enslaved African-Americans, who revolt in hopes of changing their political fortunes.

Often depicted by scholars as a prelude to greater conflict later in the war, Opothleyahola's Rebellion should be understood as the catalyst the plunged the region into intratribal warfare and a significant military event in its own right. The rebellion produced a rare winter campaign that played out over three battles. The campaign witnessed shifting politics and unclear loyalties, ambitious leaders and sharp battles, and warfare that reflected both American and Indian roots and blurred the line between civilians and soldiers. Opothleyahola's Rebellion tore at the roots of the Confederate-Indian alliances and paved the way for years of intra-tribal warfare to come.

Having rejected alliances with the Confederacy and called to the United States for helpcrying that "now the wolf has come" - the pleas of Loyal Creeks and Seminoles reached the reached the desk of Edwin H. Carruth, a Federal Indian agent in Kansas who had the unenviable job of serving tribes in Confederate-held Indian Territory whom he couldn't visit. Carruth accordingly urged the Creeks to send "a delegation of your best men" to meet with him in Kansas. Carruth further promised that "the President will not forget you. Our armies will soon go south and those of your people who are true and loyal to the Government will be treated as friends...His soldiers will soon drive these men who have violated your homes from the land they have treacherously entered." 92

${ }^{92}$ Edwin Carruth to Hopoeithleyahola and Hok-tar-hah-sas-Harjo, September 10, 1861, Official Records 8 , 25. The term "Loyal Creeks" and "Loyal Indians" has been used by historians previously, and I use it here as an umbrella term to describe all of Opothleyahola's followers and those who eventually fought for the United States. While technically Opothleyahola, Sands, and others did advocate continued adherence to existing Federal treaties 
In promising the Creeks prompt aid, Edwin Carruth either engaged in wishful thinking or willfully deceived the Loyal Creeks. Throughout 1861, Federal authorities in Washington were deluged with requests for troops from all over the South; Union forces numbered too few to meet the many demands of the war's early months. Indian Territory did not register as a strategic priority in Washington, D.C., and there was little chacne of Federal troops being dispatched to Kansas to liberate Indian Territory with any haste. Carruth could not have been blind to these circumstances. Finding himself in an impossible position, perhaps Carruth simply sought to hearten the Loyal Creeks to the South, and in this he probably succeeded.

Although we don't know how Sands and Opothleyahola reacted to Carruth's messageindeed, one of the frustrating aspects of examining Opothleyahola's campaign is the dearth of sources from Loyalist perspectives - the news likely cheered the Loyal Creeks. It was their first meaningful contact with the Federal government since May, and Carruth pledged a return of United States forces to Indian Territory to put an end to Confederate scheming. In accordance with Carruth's request, a combined delegation of Creeks, Seminoles, and Chickasaws headed north to meet with Carruth in Kansas. Leading the Creek portion of the delegation was none other than Sands himself, leaving Opothleyahola in charge of the Loyal Creek faction in Indian Territory. ${ }^{93}$

Whatever Sands and the Loyal Creeks hoped to find in Kansas, they must have been sorely disappointed; little Federal assistance awaited the Indian delegation upon their arrival. Nevertheless, the Loyal Creeks claimed they could provide "five or six thousand warriors to the Government to fight for the cause of their Great Father at Washington." The local Kansan press

(they were "loyal"), it's important to note that they did not rebel against Confederate authority out of any desire to preserve or protect the Union. They remained loyal to the U.S. for their own internal reasons.

${ }^{93}$ McBride, Opothleyaholo and the Loyal Muskogee, 150-152. 
approved of the Loyal Indians' zeal, noting that they "would be a valuable accession to the Federal army in putting down their rebellious brethren...we trust they will be accepted and assigned to those parts where their mode of warfare will be most efficient."94

Yet there was no Federal force preparing to strike at the Confederates' grasp over Indian Territory. Rather than meeting with a liberating army, the delegation was instead forwarded on to Washington, D.C. to meet with President Lincoln personally. It was a symbolic gesture, meant to generate goodwill and indicate that the Federal government hadn't forgotten its Indian wards. In practice, it proved meaningless: the journey to Washington took weeks, and it effectively removed Sands from the picture in Indian Territory. Carruth's promises proved empty, and yet again, the United States government had failed to uphold its obligations to the denizens of Indian Territory. It would be under Opothleyahola's leadership alone that the Loyal Creeks would face the deteriorating situation in the weeks and months ahead. ${ }^{95}$

With Sands absent, Opothleyahola took up the mantle of leadership decisively. By early September, if not sooner, Opothleyahola commenced a widespread mobilization of all those opposed to the Confederate alliance. Thousands of men, women, and children left their homes and began gathering at Opothleyahola's plantation on the Canadian River. The numbers continued to swell as the weeks passed; although estimates of the party's size vary, it is probably fair to suggest that between four and six thousand followers joined Opothleyahola that autumn. ${ }^{96}$ What did Opothleyahola and his followers hope to accomplish? Illiterate, Opothleyahola left almost no written record, and contemporary sources from the vantage point of Loyal Indians are equally scarce. Even simply understanding what happened can be a struggle. Recognizing the 149.

${ }^{94}$ Lawrence Republican [Lawrence, KS], November 29, 1861; Debo, The Road to Disappearance, 148-

${ }^{95}$ Debo, Road to Disappearance, 148-149.

${ }^{96}$ [Insert brief histo. discussion of Opothleyahola's party size once ILL sources arrive] 
limitations of sources, we must carefully examine Confederate writings, civilian diaries, newspaper accounts, and oral histories to uncover just what happened and why during Opothleyahola's Rebellion in the autumn and winter of 1861.

By refusing to ally with the South, Oktaharsharjo, Opothleyahola, and others were rebelling against the authority of both the Creek National Council and the Confederacy. As historian Troy Smith has noted, "the assemblage of Indians and blacks represented a rejection of the Five Tribes' governments." The Loyal Creeks feared for their safety, and mobilizing afforded them some degree of protection. As Oktaharsharjo later recounted to Federal Indian agents: "We have no opportunity to defend ourselves, although the Union men among us are the more numerous. The Texans were on one side of us, and other Southern men on another, and we had to back out. We had not means of helping ourselves. All odds were against us. Many of our men said we must fight, but others said wait until assistance comes from afar." ${ }^{97}$

Recognizing the perilous political waters into which they had waded, and fearing the possibility of Confederate retribution, Oktaharsharjo, Opothleyahola, and other Creek leaders orchestrated the mobilization of thousands of dissident Creeks, Seminoles, African-Americans, and others into camps along the North Fork of the Canadian River. Two striking features define this immense Indian rebellion: its diverse composition and tremendous size. Unsurprisingly, thousands of Creeks constituted the bulk of the rebellion: primarily Upper Creeks, although some Lower Creeks joined the old chief as well. Hundreds of Seminoles who also opposed their nation's Confederate alliance likewise joined. So too did hundreds of African-Americans,

97 "Interview with the Chiefs and Commissioner Dole," Lawrence Republican, January 2, 1862; "The Indians and the Government," New York Times, December 22, 1861; Troy Smith, "Nations Colliding: The Civil War Comes to Indian Territory," Civil War History 59:3 (Sept., 2013), 308. Smith's work is reminiscent of the arguments made by scholars of the colonial and early period of Creek history, such as Joshua Piker, Robbie Ethridge, and Andrew Frank, who emphasize the importance of the Creek town within Creek society. Smith's statement suggests - although he himself doesn't make this argument - that perhaps these older colonial-era loyalties to the town continued well into the nineteenth-century. 
including African-Creeks and African-Seminoles, both free blacks and enslaved, who hoped the rebellion presented an opportunity to gain their freedom. Small numbers of Native Americans from nearly a dozen other tribes rounded out this deeply diverse rebellion. For each of these groups, the challenges and processes of mobilizing looked different.

For Creek Indians, especially Upper Creeks, joining Opothleyahola stemmed from both their desire to stay out of the war and their loyalty to their local towns and leaders. Opothleyahola's old age and long history as a leader within his tribe lent him considerable influence amongst the Creeks, and Opothleyahola desperate attempted to keep his people out of out of the fraudulent Confederate alliance and the Civil War. James Scott, the ten-year old Creek boy whose family would join Opothleyahola along the Canadian River, recalled Opothleyahola's personal efforts to keep the Creek Nation out of the war. "Opuithli Yahola's heart was sad at all the war talk," James recalled. "He visited the houses of his followers or any of the Indians and gave them encouragement to face all these things, but above all to stay out of the war. It was no affair of the Indians." Not only had Opothleyahola walked amongst his own people advocating peace, but he had likewise taken part in the July delegation to Antelope Hills, where he urged the Plains Indians to stay out of the war. Creeks, Seminoles, and Plains Indians alike all understood Opothleyahola's pro-neutrality, anti-Confederate politics clearly, and by joining him they indicated their approval of his desire for peace. ${ }^{98}$

As Creeks chose to leave their homes to join the rebellion, they enjoyed the luxuries of both time and unity. They could pack their belongings into wagons, round up livestock, prepare food, secure their homes, and convoy together with other families on the journey to Opothleyahola's camp. James Scott rounded up the cattle, watched as the beef cooked and pork

\footnotetext{
98 “Interview with James Scott," IPP, WHC, OU.
} 
dried, and with his father, mothers, and sister, joined a wagon train to the Canadian River. They trusted Opothleyahola, "the recognized grand old man who had led them only a few years before over the Trail of Tears" and believed he would lead them through the present crisis again. Whole families left to join the Creek chieftain. Willie Larney's grandfather and parents travelled with Opothleyahola throughout Indian Territory into Kansas; so did Joseph M. Grayson's father. Willie Tiger's grandfather, a Euchee Creek Indian, joined a group of Opothleyahola's followers on Brown's Creek. Creeks left their homes ready for the journey, at their own pace, and often in the company of family and friends. ${ }^{99}$

Members of other tribes, most notably the Seminoles, joined Opothleyahola as well. As with the Creeks, the Seminoles had been divided over a Confederate alliance. Although initially in support of neutrality, the absence of the United States and the presence of Texan troops in former U.S. army forts near his border convinced Seminole leader John Jumper "that his country would be overrun, if he did not yield." Shortly after the Creeks signed their treaty with the Confederates on July 20, the Seminoles followed suit on August 1. Yet as word spread among the Seminoles that certain Creek chiefs had not been present for the treaty negotiations and opposed the alliance, a number of prominent Seminoles denounced the Seminole-Confederate alliance. Seminole leaders such as Billy Bowlegs, John Chupco, Pascofar, and Halleck Tustenuggee all gathered groups of Seminole followers, perhaps as many as 900, and joined Opothleyahola. ${ }^{100}$

\footnotetext{
99 “Interview with James Scott,” IPP; “Willie Larney Interview,” IPP; “Joseph M. Grayson Interview,” IPP; "Willie Tiger Interview," IPP.

${ }^{100}$ E.H. Carruth, quoted in Abel, American Indian as Slaveholder and Secessionist, 86, footnote 122; Lancaster, Removal Aftershock, 137; "Interview with George Scott,” IPP G.C. Snow to W.G. Coffin, September 29, 1862, Annual Report of the Commissioner of Indian Affairs (Washington: Government Printing Office, 1862), 142143. Owing in part to a lack of sources and the tribe's relatively diminutive size, comparatively little has been written about the Seminoles' experience during the war. Jane Lancaster's Removal Aftershock offers a fine wider
} 
The addition of the Seminoles to the growing rebellion proved valuable, as some of these Seminoles were veterans of the long-running Seminole Wars in Florida. Whereas the Creeks, Cherokees, and other "civilized" tribes had enjoyed decades of relative peace, the Seminoles opposed removal violently and waged years of guerrilla warfare against the United States army in the swamps of Florida. Ironically, these veterans of the conflict against the United States would soon be pitted against the Confederacy, and their military experience likely proved valuable to Opothleyahola. ${ }^{101}$

The informal leader of these Seminoles was Halleck Tustenuggee. In his fifties, Tustenuggee gained a reputation as a fierce, intractable foe of the U.S. Army during the Second Seminole War. A man with "features as delicate as a female," one Seminole War veteran described Halleck Tustenugge as "a great rogue," "a capital actor," and as "self-willed and unmanageable as an unbroken mule.” Halleck opposed removal westward so staunchly that he murdered his sister for her willingness to migrate. Halleck was duped into his own capture in Florida, and he was sent to Indian Territory unwillingly. When one member of his warband accused Halleck of betraying the Seminole cause, the Seminole chief "sprang like a tiger" on the poor fellow and bit off his right ear, shouting "Halleck-tustenuggee! I'll make you understand that I am your chief, whether prisoner or not!” It was this fierce individual would lead the Seminoles into battle during the Opothleyahola's rebellion. ${ }^{102}$

history of the Seminole tribe post-removal, including an informative if brief chapter on the Civil War. Regarding the number of Seminoles in Opothleyahola's party, George Scott, whose father Tallah Marshall Yahola was a Seminole who joined Opothleyahola, had been told there were "several hundred Seminole Indians" in the party. Yet in a September 1862 report, 919 Seminoles are listed as refugees in Kansas, most of whom came with Opothleyahola. ${ }^{101}$ Lancaster, Removal Aftershock, 136-138.

102 George A. McCall, Letters from the Frontiers (Philadelphia, PA: J.B. Lippincott \& Co, 1868), 404-414; John K. McMahon, History of the Second Seminole War, 1835-1842 (1967; repr., Gainesville: University Presses of Florida, 1985), 281-282; “Report of James McIntosh,” January 1, 1862, Official Records 8, 23. 
Although most of the Native Americans in Opothleyahola's swelling camps were Creeks and Seminoles, smaller contingents of Indians from a wide variety of tribes also joined the rebellion. Loyalist Indians from the other Five Tribes also made their way to Opothleyahola, including Choctaws, Chickasaws, and Cherokees. Members of other eastern tribes that had been removed to Indian Territory—including Shawnees and Delaware—likewise joined the Creek chieftain. A smattering of individuals from the "wild tribes" of the Plains also joined in Opothleyahola's Rebellion, including Comanches, Kickapoos, and Wichitas, among others. One Confederate lamented that "warriors from no less than eighteen tribes" had joined the rebellion. In seeking to understand why Plains Indians would join the old Creek chief, it is worth remembering that Opothleyahola had recently visited Antelope Hills in July for the express purpose of convincing the Plains Indians to remain neutral. Opothleyahola likely fostered personal connections with the Plains tribes during this visit, and it was perhaps these connections that drew some of them to his aid that autumn. ${ }^{103}$

Hundreds of African-Americans, both enslaved and free, joined Opothleyahola's Rebellion too. Historian Steven Hahn has argued that slaves "could be acutely aware of conflict that erupted between white people and nations ruled by white people; that slaves often imagined a set of possible allies and enemies...that slaves often became conversant with institutions and issues of local and national politics.” This argument transplants well to Indian Territory, where

\footnotetext{
${ }^{103}$ Lancaster, Aftershock Removal, 138; Abel, American Indian as Slaveholder and Secessionist, 252, n511; D.N. McIntosh to John Drew, September 11, 1861, John Drew Papers, Gilcrease Institute; "Letter from the Creek Nation,” January 2, 1862, Van Buren Press [Van Buren, AR] [letter dated December 20, 1861].
} 
slaves held a nuanced understanding of Indian politics, and clearly understood that Opothleyahola represented a plausible ally and a route to freedom. ${ }^{104}$

Among the Creeks in particular, slaves had cause to run away. In recent months, the Creek Nation had passed legislation designed at constricting the freedom of slaves within their borders, instituting rules requiring slaves to carry a pass while traveling, barring slaves from owning weapons of any kind, barring slaves from business transactions, preventing black slaves from preaching to Indians, etc. Moreover, free blacks were barred from the Nation; free blacks within the Nation either had to leave its borders or choose a master and voluntarily enslave themselves. Thus, as Gary Zellar has noted, "Whether it was the promise of freedom extended...or to defend a certain kind of freedom already experienced by some, African Creeks resisted their enslavement in the most convincing ways available to them." For nearly 500 African Creeks and African Seminoles, that meant joining Opothleyahola. ${ }^{105}$

Slaves knew of Opothleyahola by reputation, and they also knew of his rebellion against the Confederacy and the Lower Creeks. Lucinda Davis had heard of Opothleyahola as a great orator. 'Dey say when he was a little boy he was called Hopothli, which means 'good little boy,' and when he git grown he make big speeches and dey stick on de 'yoholo.' Dat mean 'loud whooper'." Nellie Johnson understood that her master Roley McIntosh (the brother of assassinated William McIntosh, and Daniel and Chilly McIntosh's uncle) had a bitter relationship with Opothleyahola, and she was well aware that Upper Creeks "all go off after that old man Gouge, and he take most of the Seminole, too." 106 73-75.

${ }^{104}$ Steven Hahn, Political Worlds of Slavery and Freedom (Cambridge: Harvard University Press, 2009),

${ }^{105}$ Gary Zellar, African Creeks: Estelvste and the Creek Nation (Norman: University of Oklahoma Press, 2007), 42-43, 47; Dallas Herald [Dallas, TX], April 10, 1861.

${ }^{106}$ Baker, eds., "Lucinda Davis," WPA Oklahoma Slave Narratives, 107-117; Baker, eds., "Nellie Johnson,” WPA Oklahoma Slave Narratives, 224-228; Chapman, Chief William McIntosh, 14. 
But most of all, slaves indicated their understanding of Opothleyahola by joining his ranks, recognizing his rebellion offered a path to freedom. Indeed, Opothleyahola's followers actively recruited slaves to escape to his camp. Mary Grayson recalled "some Upper Creeks came up in the Choksa bottoms talking around the folks there about siding with the North. They were talking, they said, for old man Gouge.” Yet Grayson's father Jacob and two uncles, William and Hector, had already escaped. Even before Opothleyahola could reach them, slaves reached Opothleyahola. ${ }^{107}$

The Grayson men's departure is indicative of the struggles runaway slaves faced, as they did not enjoy same luxuries as Indians who decided to join the Creek chief. Slaves had to run away from their masters; they literally escaped to Opothleyahola. Discussions and preparations for the journey were short and secret, and hard choices had to be made about who could make the journey to freedom and who had to be left behind. Instead of days or weeks to pack and prepare, slaves had to travel light, and Mary Perryman's mother could only cook limited amounts of food in the secrecy of darkness. Moreover, as Mary's mother's tears attest, there were powerful emotional costs, as well. While Jacob, William, and Hector fled, Mary and her mother remained in bondage. Also left behind was William's daughter Phoebe, who recalled "runaways was riding ponies stolen from their masters." 108

Despite the unique hardships they faced, the fact that hundreds of slaves and free blacks fled to Opothleyahola speaks both to their political awareness and their understanding that Opothleyahola was indeed an ally. Opothleyahola understood the value that slaves brought to his camp and recruited them to his side. Thus Opothleyahola's great mobilization brought together

\footnotetext{
${ }^{107}$ Baker, eds., "Mary Grayson,” WPA Oklahoma Slave Narratives, 171-178.

${ }^{108}$ Baker, eds., "Mary Grayson," WPA Oklahoma Slave Narratives, 171-178; Baker, eds., WPA Oklahoma Slave Narratives, "Phoebe Banks," 30-34.
} 
Creeks, Seminoles, Indians of many other tribes, and enslaved and free blacks — all mustered in opposition to the Confederacy and willing, if necessary, to fight for their freedom.

As Upper Creeks, Seminoles, other "civilized" and "wild” Indians, and AfricanAmericans rallied around Opothleyahola throughout September and October, the size of the rebellion swelled into the thousands. Although estimations of Opothleyahola's party size vary, a reasonable approximation would place the total between 4,000-6,000; included in this estimation are nearly 900 Seminoles and 500 African-Americans. Although civilians and families comprised the bulk of the assemblage, the mobilization nevertheless also provided Opothleyahola with a makeshift "army." He had between 1,500 and 3,000 warriors at his disposal at various times over the course of the rebellion. ${ }^{109}$

When taking into account the total population of Indian Territory, the size and scope of Opothleyahola's Rebellion becomes staggering. In 1860, Indian Territory possessed an Indian population approaching 50,000; the Creek Nation alone numbered 13,500. Assuming that 5,000 followers joined Opothleyahola, most of whom were Upper Creeks, than roughly one-fourth of the entire Creek Nation left their homes to join "Old Gouge" on the banks of the Canadian River. Seminole Nation numbered over 2,200 in 1860; two-fifths of all Seminoles in the Territory joined Opothleyahola. Out of the nearly 2,500 slaves held by Creek and Seminole masters, close to one-fifth of them escaped and linked up with the rebellion. In sum, one out of every ten Indians in the Territory left their homes that autumn in rebellion against the Confederacy. This was a remarkable act of dissent; unparalleled among Unionists in the South. The figures offer a final, hammering reminder of the fraudulent way in which Confederate-Indian treaties were

${ }^{109}$ [Insert appropriate footnotes: Minges, Zellar, Johnston, ORs, etc.; develop a succinct breakdown of scholarly and contemporary estimates of Opothleyahola's party size for this footnote, as well]. 
negotiated, the weakness of the Confederate cause among many Native Americans, and the willingness of many Indians to fight against the Confederacy. ${ }^{110}$

The great mobilization under Opothleyahola did not go unnoticed. The gathering of thousands of disaffected "Loyal" Indians caused first concern, then fear and panic, and finally action among the Confederate authorities in Indian Territory. As the ranks of rebellious Indians swelled, Confederate authorities attempted to gather sufficient military strength while simultaneously hoping to diplomatically bring Opothleyahola to heel and prevent the shedding of blood. These overtures of peace fell flat, and Opothleyahola's Rebellion resulted in a rare winter offensive in November and December. Thousands of Native American, Texan, and Arkansan troopers struck out to hunt down the defiant old chief and "either compel submission to the authorities...or drive [Opothleyahola] and his party from the country." The resulting military campaign and exodus of Opothleyahola's followers into Kansas deserves greater attention afforded to it by historians, as it sheds light on the brutal nature of warfare that would come to haunt Indian Territory. ${ }^{111}$

Within days of the Creek Nation's schism and Opothleyahola's and Sand's appeal to President Lincoln, news of the emerging unrest in Creek country reached Confederate authorities. The first reports of Opothleyahola's activity came to Colonel Daniel McIntosh. A "fine-looking, intelligent gentleman," who "will compare well to any Colonel in the army," Daniel belonged McIntosh clan with whom Opothleyahola had long feuded. He commanded the

${ }^{110}$ Zellar, African Creeks, 45; Doran, "Population Statistics of Nineteenth-Century Indian Territory," 501; Doran, "Negro Slaves of the Five Civilized Tribes," 347.

111 "Report of Col. Douglas H. Cooper," January 20, 1862, Official Records 8, 5. 
recently raised $1{ }^{\text {st }}$ Creek Mounted Rifles. In early September, McIntosh penned a warning to Colonel John Drew of the Confederate Cherokees, cautioning Drew that if prompt action were not taken, the Creek rebellion might spill over into Cherokee Nation. "We have had many reports from Hopoithyalo of an allarming [sic] character," McIntosh advised. "But it is now certain that he has combined with his party all the surrounding wild tribes and has openly declared himself the enemy of the all the South. Negros are fleeing to him from all quarters-no less than 150 have left within the last three days." Warning that the growing rebellion "cannot long exist here without seriously affecting your country," McIntosh recommended the rebellion "be put down immediately" and asked that Drew's Cherokees "come over in haste" to Creek Nation. ${ }^{112}$

While McIntosh fretted over the rising size of the revolt taking place in his country, rumors ran rife throughout the Nation that Opothleyahola intended to wage war. In early September, word reached North Fork Town, a prominent Creek village nestled between the two forks of the Canadian River, that Opothleyahola's force numbered 3,000, "had raised the union flag, and sent notice to the women and children to leave North Fork, as he intends to sack and burn the village." Panicky Creeks fled the town; "[n]o one would stop in the place." Although the report of impending attack proved incorrect, the affair demonstrates the panic that gripped the Nation as the rebellion increased in size. ${ }^{113}$

Calls for help by Creek Confederates grew more urgent as September passed into October. On September 30, the $1^{\text {st }}$ Creek conducted a military review. One observer noted the

${ }^{112}$ D.N. McIntosh to John Drew, September 11, 1861, John Drew Papers, Gilcrease Institute.

${ }^{113}$ Van Buren Press [Van Buren, AR], October 16, 1861 [dispatch dated Sept. 9]. The town of Van Buren, Arkansas is near Fort Smith and sat almost on the line between Arkansas and Indian Territory. Unsurprisingly then, the Van Buren Press routinely reported on events across the line in the Territory. The Press's coverage of the campaign perfectly mirrors the campaign itself. Small columns noting Opothleyahola's dissent began appearing in early October; by November and December, letters and columns reporting on the campaign took up increasingly prominent space within the paper's pages. A rarely cited source, the correspondents who wrote to the Press from Indian Territory provide a wealth of valuable information. 
Creeks were "of all ages, sizes, colors, and descriptions, some painted red, some black...but a more determined set of looking men, I never saw.” When the Confederate Creeks were told to prepare to march against Opothleyahola, they let loose a "savage yell" which "seemed to burst forth from every mouth" and fired their guns into the nearby woods. Although the Confederate Creeks apparently possessed no apprehensions about battling their wayward brethren, McIntosh worried that Opothleyahola would march on him. Within days of the military review, McIntosh turned to Brigadier General Albert Pike asking for military assistance. McIntosh reported that his scouts now pegged Opothleyahola's force at 6,000, and rumors of an attack on McIntosh abounded. Once again, McIntosh pleaded for help. "Sir the time has now come when this matter must be looked into, I would suggest that you send over the forces in the Cherokee Nation and those in the Choctaw Nation." With the combined weight of the Confederate Indian regiments, "we go up and put an end to the whole matter. I think this all important, and ought to be done immediately." 114

McIntosh's pleas for help were accompanied by those of Moty Kanard and Echo Harjo, the principal chiefs of the Confederate Creeks. The two men wrote another missive to John Drew, urging him to send his Cherokees to the Creeks" aid. "We are threatened daily of an attack from the dissatisfied portion of the Creeks," they reported. Even worse, "dispite [sic] all appeals to patriotism and treaty obligations our ranks are diminishing." Opothleyahola's continued presence in the Nation was sapping Confederate strength and morale, and the chiefs cautioned that "unless we get aid from some quarter, our difficulties will continue to an unaccountable

${ }^{114}$ D.N. McIntosh to Albert Pike, October 3, 1861, John Drew Papers, Helmerich Center, Gilcrease Institute; "Letter from Creek Nation," Van Buren Press, October 9, 1861 [letter dated October 3]. 
extent." The Creek chiefs promised Drew food and forage if he would send even part of his command to assist the Creek Nation. ${ }^{115}$

Despite these pleas for help from Confederates in the Creek Nation, immediate military aid was not forthcoming. Although appeals for help reached on John Drew, his $1^{\text {st }}$ Cherokee Mounted Rifles only began recruitment in late August; its ranks were not yet filled. Drew simply possessed too few men and arms to be of much assistance. Likewise, the recently-recruited $1^{\text {st }}$ Choctaw and Chickasaw Mounted Rifles under Colonel Douglas Cooper were nearly bereft of arms as well. Cooper complained that he "could not arm over three companies from all the guns in the regiment." While Opothleyahola's ranks swelled throughout autumn, local Confederate forces were simply unprepared to challenge the recalcitrant Creek chief, whose warriors numbered in the thousands. ${ }^{116}$

Hoping to avoid bloodshed and stave off a war for which they were unprepared, various Confederate leaders pursued diplomatic efforts to bring Opothleyahola to the table. The first was Cherokee Chief John Ross. On August 24, John Ross sent a brief message to "the Chiefs and Headmen of the Creek Nation," announcing the Cherokees' decision to ally with the Confederate States. He hoped to "preserve and maintain the Brotherhood of the Indian Nations in a common destiny," and he also informed the Creeks of John Drew's appointment to raise a regiment of Cherokees for Confederate service. ${ }^{117}$

This was the first that the Loyal Creeks heard of the Cherokee-Confederate alliance, and the news stunned them. John Ross spearheaded the movement for Indian neutrality, and to learn

115 Moty Kanard and Echo Harjo to John Drew, October 10, 1861, John Drew Papers, Gilcrease Institute.

116 Gaines, The Confederate Cherokees, 24; Douglas Cooper to Jefferson Davis, July 25, 1861, Official Records 3, 614. Cooper's personal report to Jefferson Davis and appeal for arms likely stemmed from his service under Jefferson Davis's Mississippi Regiment during the Mexican-American War.

117 John Ross to the Creek Nation, August 24, 1861, Papers of Chief John Ross 2, 482. 
that he had suddenly shifted course and allied with the Confederacy was hard to believe. Dubious of the message's authenticity, on September 14 Oktaharsharjo and Opothleyahola wrote back to Ross for clarification, admitting, "We don't know wether [sic] this is the truth or no." Ross quickly responded in the affirmative, and expressed hope that "under the present extraordinary crisis, for all the red Brethren to be united among themselves in the support of our common rights and interest by forming an alliance of peace and friendship with the Confederate States of America." 118

Opothleyahola and the Loyal Creeks viewed John Ross's alliance with the Confederacy as a betrayal, but it did nothing to dissuade them from their rebellion. Indeed, many in Opothleyahola's camp suspected that a majority of Cherokees disfavored the Confederate treaty. In October, Creek Chief Moty Kennard wrote to Ross informing him of Opothleyahola’s recalcitrance, noting that the rebellion was "adding to their number the dissatisfied from every Tribe." Kennard worried, "If some timely remedy is not used for its arrests it will and must end in civil war," and asked Ross to send "a few of your old men well known to the party to give them...brotherly talk in the right direction." 119

Hoping for peace, John Ross proved willing to "do anything in my power to adjust and harmonize" the disaffected Creeks, and he promptly sent a delegation of Cherokees, headed by Joseph Vann, to treat with Opothleyahola. He further invited Opothleyahola and other Creek leaders to visit Ross personally at Tahlequah, "where we may smoke the Pipe of Peace and friendship around our great council fire.” Ross also conferred with Albert Pike, who agreed to support the mediation effort and "kindly issued letters of Pardon to Opothleolo \& his

118 John Ross to the Creek Nation, August 24, 1861, Papers of Chief John Ross, 2, 482; John Ross to Opothleyahola and other chiefs and headmen of the Creek Nation, September 19, 1861, Papers of Chief John Ross, 2, 487-488.

${ }^{119}$ Moty Kennard to John Ross, October 1, 1861, Papers of Chief John Ross 2, 489-490. 
People...also, of Safeguard for him \& Six others to visit me at this place [Tahlequah]." Pike's offer to pardon Opothleyahola and his follower was a stunningly obtuse proposal, given that it was Albert Pike's underhanded negotiating tactics and fraudulent treaty-making that gave Opothleyahola and his followers immediate cause to rebel in the first place. ${ }^{120}$

While Joseph Vann's delegation set out to talk to Opothleyahola, the military situation in Indian Territory darkened. The October rumor that Opothleyahola was planning to attack Daniel McIntosh's Confederate Creek regiment caused Col. Douglas Cooper to detain the $9^{\text {th }}$ Texas Cavalry—passing though Indian Territory on their way to Arkansas—and send them to McIntosh's aid. When the rumors of the attack proved false, Col. Cooper allowed the Texans to continue their journey to Arkansas, where they might face the Federal threat along the Missouri border. Nevertheless, the sudden presence of armed Confederate Texans in the area heightened tensions in Opothleyahola's camp and throughout the countryside, causing Ross to fire off another message to Opothleyahola informing him that the Texans short-lived presence was the product of "mischievous lies circulated by wicked and designing men," and the Texans had already "passed thro this place in peace and good order" to Arkansas. ${ }^{121}$

Joseph Vann's delegation managed to find an audience with Opothleyahola, but "failed to elicit anything definite." Opothleyahola claimed that he initially journeyed to the Canadian River simply to "make a Cowpen," and in hopes "to live in peace \& quiet away from the scene of strife and confusion." The thousands of followers who joined him did so due to "false and exaggerated reports," and that his followers likewise "also wished to live in peace." Opothleyahola also vowed that "he had no design whatever of making war upon any Body. His wish was to be at

\footnotetext{
120 John Ross to Opothleyahola, et. al. and John Drew to Motey Kennard and Echo Harjo, October 20, 1861, Papers of Chief John Ross 2, 489-490; Gaines, Confederate Cherokees, 27.

${ }^{121}$ John Drew to Opothleyahola, October 11, 1861, Papers of Chief John Ross 2, 495-496; John Ross to William P. Ross, [November 16, 1861?], Papers of Chief John Ross 2, 495-496, 503-504.
} 
peace with all the red and white people." The old Creek chief further stated that he would share Vann's concerns with his fellow headmen who "were not all then present" and inquire as to their position on the matter of peace. Lastly, he claimed to have made an effort to reach out to the McIntosh clan in hopes of settling their differences. Still, Opothleyahola made known his discomfort with the Confederacy. He compared the Confederate Creeks to "people, who after having used an axe a long time, see a new one and take it instead"; Opothleyahola "preferred the old axe." $" 122$

Opothleyahola appears to have told several half-truths in his meeting with the Cherokee delegation. Opothleyahola's story that he played no part in mobilizing the thousands who now accompanied him along the banks of the Canadian - that like-minded lovers of peace simply "gathered around him"-ignores the fact that Opothleyahola's followers actively sought out and recruited Creeks and African-Americans to join their ranks. Likewise, Opothleyahola's claim that "he had no design whatever of making war" proved equally disingenuous. There were members of Opothleyahola's camp who had indeed advocated taking the offensive, but the shortage of ammunition and gunpowder quashed their aspirations. More importantly, however, Opothleyahola had actively communicated with the Federal government in hopes of spurring a Federal military expedition into Indian Territory to push out the Confederates and liberate Creek Nation. It is probably true that most of Opothleyahola's followers wanted peace, and perhaps Opothleyahola thought he could avoid war for his people by letting the U.S. Army tackle the tough task of reasserting Federal authority. Regardless, Opothleyahola's letter to President Lincoln and the subsequent Loyalist delegation to Kansas and Washington were explicitly designed to provoke a military response from the United States. Opothleyahola may not have

\footnotetext{
122 "Letter from the Cherokee Nation," Van Buren Press, October 20, 1861; John Ross to Motey Kennard and Echo Harjo, October 20, 1861, Papers of Chief John Ross 2, 497-498.
} 
wanted to wage war himself, but he surely wanted the United States military to rid Creek Nation of the Confederacy's presence. Col. Daniel McIntosh suspected Opothleyahola's duplicity, and he simply believed the whole affair was an attempt by Opothleyahola "to gain time, hoping to receive backing from the North." 123

Diplomatic efforts began to break down in the wake of Vann's visit to Opothleyahola in October. Moty Kennard and Echo Harjo wrote to John Ross thanking him for his efforts to secure peace, but the two Confederate chiefs ultimately felt "there was no hope for a friendly adjustment of the difficulty." Echoing Daniel McIntosh's suspicions, the Creek chiefs determined that "if they [Opothleyahola's party] get aid from the North which they are making every effort to do they will be our most formidable enemy." Opothleyahola's warriors knew the lay of the land just as well as the Confederate Indians, and the daily escape of black slaves to Opothleyahola's camps caused "great injury to many of our best citizens." Ultimately, the chiefs concluded, it was "necessary for them to be put down at any cost. Therefore so soon as we are reinforced which we daily expect we shall proceed without further delay and put an end to the affair." 124

For John Ross, the probability of an intra-Creek, inter-Indian civil war was horrifying. After all, through most of 1861 Ross stood as the most ardent proponent of neutrality. The Cherokee Nation was the last of the Five Tribes to ally with the South, and Ross's decision to ally with Confederacy was largely the result of political maneuvering by Stand Watie, It was also rooted in Ross's desire to preserve inter-tribal peace among the Native Americans of Indian Territory. Now Ross and Opothleyahola stood on opposite sides of a growing precipice; opposite

${ }^{123}$ John Ross to Moty Kennard and Echo Harjo, Papers of Chief John Ross 2, 497-499; "Letter from the Cherokee Nation," Van Buren Press, November 71861 [letter dated October 20, 1861]; "The Indians and the Government," New York Times," December 22, 1861.

${ }^{124}$ Motey Kennard and Echo Harjo to John Ross, October 18, 1861, Papers of Chief John Ross, 2, $496-497$. 
sides of a looming civil war. Failing to fathom the depths of that precipice, Ross implored Kennard and Harjo to continue diplomatic efforts at a peaceful solution. "Brothers, we are shocked with amazement at the fearful import of your words! Are we to understand that you have determined to make a Military demonstration, by force of Arms, upon Opothleyaholo \& his followers, at the cost of civil war among your own people and thereby involve your red Brethren, who are in alliance with the Confederate States?" Ross begged the Creek Confederate chiefs to "preserve peace and harmony." He advised that the Creek chiefs issue a proclamation to Opothleyahola's follower asking that they "return to their respective Homes with their families" and that "Indian Regiments should be judiciously quartered" in the Creek Nation to preserve peace. $^{125}$

However admirable, Ross's continued hopes for peace were foolish. He seems never to have truly understood the gravity of the rebellion in Creek Nation, nor did he comprehend that Opothleyahola's party was in fact in league with Federal authorities. Although much ink and effort was spent by Confederate authorities to find a peaceful, diplomatic solution to the crisis in Creek country, the reality was the opposing parties were at an impasse. The Creek National Council negotiated and ratified a treaty with the Confederacy that Opothleyahola's party would never accept. By mobilizing in opposition and communicating with Union authorities, Opothleyahola openly defied the Creek National Council and the Confederacy. The escape of hundreds of slaves to the rebellion's camps only forced the issue further. While Opothleyahola may have wanted to avoid war for his people, the Confederate Creeks and Confederate military correctly identified him as a threat to their authority and to Indian Territory. Ironically, in

${ }^{125}$ John Ross to Motey Kennard and Echo Harjo, October 20, 1861, Papers of Chief John Ross, 2, 497-499. 
Opothleyahola's bid to keep his people out of the Civil War by spurning the Confederacy, he invited war to his doorstep.

By late October, Confederate forces finally began moving into position to strike at Opothleyahola; Daniel McIntosh received his long looked-for reinforcements at last. Col. Cooper arrived in Creek Nation with the $1^{\text {st }}$ Choctaw and Chickasaw Mounted Rifles and took command. Also present was a small battalion of Confederate Creeks and Seminoles under Lt. Col Chilly McIntosh, Daniel's brother, and Seminole Chief and Major John Jumper. Col. John Drew's $1^{\text {st }}$ Cherokee Mounted Rifles also briefly arrive in late October, but since they had yet to be mustered in, they returned to Fort Gibson. ${ }^{126}$

Also en route to join this ad-hoc Indian brigade was the $9^{\text {th }}$ Texas Cavalry. A youthful regiment hailing from North Texas, the $9^{\text {th }}$ was led by Colonel William Sims and Lt. Col. William Quayle. Hailing from North Texas, these young volunteers were eager for combat, and they had orders to make their way to Ben McCulloch in northwestern Arkansas. As the $9^{\text {th }}$ Texas's various companies marched north they united in Boggy Depot, a prominent town and trading post in Choctaw Nation in early November. The $9^{\text {th }}$ Texas Cavalry was the first of several Texan cavalry regiments to become embroiled in Opothleyahola's Rebellion. ${ }^{127}$

126 "Letter from the Creek Nation," Van Buren Press, October 31, 1861 [letter dated October 26, 1861; "Letter from the Cherokee Nation," Van Buren Press, November 7, 1861 [letter dated October 20, 1861]; "Report of Col. Douglas H. Cooper," Official Records 8, 5. John Jumper's Seminoles later formed their own battalion later in the war, while Chilly McIntosh's Creeks developed into a full regiment. At this early stage, however, they appear to be a single, mixed battalion under McIntosh's and Jumper's joint command.

${ }^{127}$ James C. Bates, A Texas Cavalry Officer's Civil War: The Diary and Letters of James C. Bates, Richard Lowe, ed. (Baton Rouge: Louisiana State University Press, 1999), xxi-xxiii. Richard Lowe's edited volume of Bate's diary is the best published primary source regarding Opothleyahola's Rebellion. Bates participates in most of the campaign, including the Battles of Round Mountain and Chusto-Talasah (though not CHustenahlah). Bates kept a diary and wrote letters to his family. Bates proved himself a skilled writer, with thoughtful analysis of the campaign that often proved prescient. 
As the regiment marched north, Private Allison Sparks experienced an encounter that foreshadowed the violence to come. On a detachment ahead of the regiment sent to gather supplies, Sparks watched curiously as a "small Indian negro boy on a horse rode up." The young boy spoke the detachment's captain, then "rode away at a gallop, uttering a curious scream, terminating in something resembling the gobbling of a turkey." The captain informed Sparks the cry "was the Indian war-whoop, and meant mischief to us." The Texan detachment took shelter in a nearby mission, horses "saddled for fight or flight," watching as "the Indians in every direction appeared to be in great excitement." Left unharmed, the Texans later learned that the Indians the encountered were "a detachment left that night to join Hapothlehola." 128

On November 11, the $9^{\text {th }}$ Texas Cavalry rode into North Fork Town in Creek Nation. As they settled in for the evening and feed their horses, a messenger arrived from Col Douglas Cooper. As he had in October, once again Col. Cooper pounced on passerby Texan soldiers as an opportunity to reinforce his command in the face of the enemy. Cooper requested that the Texans join him in the field against Opothleyahola. The accommodating Texans consented and immediately prepared to move out. Ammunition and provisions were issued, and the men slept for a few hours. At four in the morning the men were roused and set out. There was some fear the Texans might be intercepted by the enemy, so the men marched "in perfect silence" and at "rapid pace," which was hastened upon receiving yet another message from Cooper stating that his force was "was retreating to meet us--\& urging us to hurry on as fast as possible." They bedraggled troopers continued their quick pace towards Cooper throughout the $12^{\text {th }}$, expecting to "find Cooper engaged with the enemy." Instead, they men arrived at Colonel Cooper's camp unscathed to find all was well. James Bates angrily wrote to his mother that the enemy had not

128 A.W. Sparks, The War Between the States, As I Saw It: Reminiscent, Historical and Personal (Tyler, TX: Lee \& Burnett, 1901), 22-23. 
"ever been nearer than 25 miles...we were not a little vexed at riding our horses so hard to no purpose." ${ }^{129}$

Douglas Cooper's urgent dispatches to the $9^{\text {th }}$ Texas Cavalry hint at both his worry, inexperience, and his respect for Opothleyahola. The day before commandeering the Ninth, Cooper wrote Lt. Col. William Ross of the $1^{\text {st }}$ Cherokee Mounted Rifles that he was "mistaken in regard to Hopoithlayahola's pacific intentions, as from reliable information, I am perfectly satisfied he is now meditating an attack on my camp." Rumors also indicated that Opothleyahola was working with 1,000 Kansan Jayhawkers near the Arkansas River, and he order Drew's regiment of Cherokees to make a "rapid march" to intercept the Kansans. This impending attack was likely the cause of Cooper's panicked missives to the $9^{\text {th }}$ Texas. Unfortunately for Opothleyahola, there were no Kansans by his side; the $9^{\text {th }}$ Texas tired their mounts for naught, and Drew's Cherokees spent several days hunting for jayhawkers that weren't there. ${ }^{130}$

Over the next few days, the white Texans got an education in their newfound Native American allies and Indian politics. George Griscom informed his diary that the enemy was "Comd'd by 'Opothlehola' the full blooded chief \& composed of all the full bloods," while the "the C S indians by col Chilly McIntosh a half breed \& comprised of all the half breeds \& quatreen.” These two Creek camps, Griscom learned, "were naturally antagonistic to each other

\footnotetext{
${ }^{129}$ George L. Griscom, "Diary of George L. Griscom, Adjutant, Ninth Texas Cavalry, 1861-1863,” George L. Griscom Papers, Dolph Briscoe Center for American History, University of Texas-Austin.; Bates, Texas Cavalry Officer's Civil War, 21, 27-28. Although Cooper's continued hijacking of Texan soldiers may have annoyed Confederate authorities in Arkansas, it's easy to sympathize with Cooper's plight. As would be the case throughout the war, Indian Territory received material, men, and reinforcements last. Cooper's policy of taking advantage of passerby troops was unorthodox but wise. While the Ninth Texas expected to march all the way to Arkansas, Col. Cooper had apparently been expecting their arrival in the vicinity for several days, as noted in the Van Buren Press [Van Buren, AR], "Letter from the Creek Nation," October 31, 1861 [letter dated October 26]. Although I have relied upon the archival manuscript of George L. Griscom's diary, an edited version has been published. See George L. Griscom, Fightin' with Ross' Texas Cavalry Brigade, C.S.A.: The Diary of George L. Griscom, Adjutant, $9^{\text {th }}$ Texas Cavalry Regiment, edited by Homer L. Kerr (Hillsboro, TX: Hillsboro Jr. College Press, 1976)

${ }^{130}$ Douglas Cooper to William P. Ross, November 10, 1861, John Drew Papers, Gilcrease Institute; John Drew to Douglas Cooper, November 20, 1861, John Drew Papers, Gilcrease Institute. It was perhaps these Kansan jayhawkers that Cooper thought might intercept the Ninth Texas.
} 
on account of family feuds “'Old Ginge [Gouge]' the nick name of Opothy...years back beheaded McI's [McIntosh's] father in old States. Hence they were enemies." Allison Sparks recalled that "Gouge had once been a great warrior of the Creek Nation and was at enmity with the family of McIntosh, the reigning chief, and in order to revenge his hatred had assembled all the least civilized of his own tribe, together with allies from other tribes, and espoused the cause of our common enemy with the Seminoles." James Bates wrote his mother that the enemy "are principally Creek Indians - with the remnant of a few wild tribes together with a few jay hawkers," led by "Opotheohola or as we call him—-Gouge.” Although the Texans occasionally got minor details of the Creek feud wrong, their quick mastery of the political crises in Creek Nation was impressive. ${ }^{131}$

While learning about Creek politics and their enemy, the Texans also got to behold their Indian allies, who made quite an impression. When the Texan troopers arrived at Cooper's camp after their hard ride on November 12, they were met "with the most extravagant demonstrations of joy firing guns shouting \& war dancing untill [sic] nearly morning." Allison Sparks recalled that the Indians "received us with a great joy as we marched through their camp and fired us a great salute, which we returned with about the same unmilitary regularity." The Indians' excitement at the Texans' arrival, along with the prospect of finally taking the offensive, led to a great war dance on either November 13 or 14, the highlight of campaign preparations. ${ }^{132}$

"Many people seem to think the Indian war dance a frivolous affair," Sparks opined, "but from my observation it is really a very serious ceremony." As the Creeks, Choctaws, and

${ }^{131}$ Griscom Papers, Briscoe Center, University of Texas-Austin; Bates, A Texas Cavalry Officer's Civil War, 28; A.W. Sparks, AS I Saw It, 23.

${ }^{132}$ Griscom Papers, Briscoe Center, University of Texas-Austin; A.W. Sparks, As I Saw It, 23-24. 
Chickasaws gathered for their dance, an Indian speaker arose and spoke to the crowd. A fellow Indian translated the gist of the speech for Private Sparks:

"Friends, Hapothlehola, one of our race who has been honored and loved by his people, has become made with his brothers and has gathered to him all the wild tribes and marched them to our homes. We offered to meet him as a friend and brother, but he turned his back to us... What does this mean? Ask the old men who have lived beyond the 'Great Water' and they will tell you it means WAR! It means that they will kill our children, it means that they will burn our homes, it means they will take away our squaws, it means they will drive off our cattle; and when we have grown weak for want of food they will hunt us down in the mountains and scalp us like wolves...Will you swear that you will never take ease again until the last of those who seek to do us harm are driven over the border? Then let us paint our faces, a sign that we look no more upon the squaw until her enemies are no more."

Throughout the speech, the orator lifted a "huge club" covered in blood and hair, and the crowd several times erupted into "screams and gobbles" and the firing of guns. ${ }^{133}$

In the wake of the Creek orator's speech, the war dance was performed in a ring "filled with painted Indians, marching a side-like manner, stepping high and fast, while they chanted a strange song." The usually stoic George Griscom penned in his diary that the Creeks "gave us the real war dance of both nations with which our boys were delighted." Griscom confessed that he and other Texans joined in the dance. With rations prepared, speeches made, dances performed, the time to end Opothleyahola's Rebellion arrived. ${ }^{134}$

${ }^{133}$ A.W. Sparks, As I Saw It, 25-27.

${ }^{134}$ A.W. Sparks, As I Saw It, 26-27; Griscom Papers, Briscoe Center, University of Texas-Austin. 
At 8 a.m. on the morning of November $15^{\text {th }}$, Colonel Douglas Cooper's troopers, some 1,400 Chickasaws, Choctaws, Creeks, Seminoles, and Texans, set out to find Opothleyahola and "either compel submission to the authorities of the nation or drive him and his party from the country." As promised during the war dance, the Indians' faces were "painted red with streaks \& spots of black," and upon the outset of the march they let loose "whoops \& yells \& screams." James Bates thought they struck "a most hideous appearance." The Indians "rode small ponies and were dressed in garb ranging from a common gent's suit to a breech [cloth] and blanket." The Indians carried a variety of arms, including rifles, smoothbore guns, and bows and arrows. This "motley assembly" set forth to defeat Opothleyahola. Upon hearing of Cooper's offensive, one denizen in Creek Nation fervently wrote, "We hope this insurrection, which has assumed rather formidable proportions, will now be 'crushed,' and 'Old Poth.', the insurgent chief be sent as a hostage to Richmond." 135

Over the next few days, the Confederate cavalry moved northwest up the Deep Fork of the Canadian River towards the "supposed" camp of Opothleyahola. The camp was successfully found within a few days; Opothleyahola was not. The old Creek chief had begun moving northwest himself towards the Kansas line. We can speculate as to why Opothleyahola would decide to move north in late October and November. First, even by this late date, Opothleyahola may still have held out hope for Union reinforcements; Confederate reports indicated Opothleyahola "anxiously" awaited help from Kansas. Yet the old chief must also have begun to harbor doubts about whether the United States army was really on its way. Moving towards

135 “Report of Col. Douglas H. Cooper," January 20, 1862, Official Records 8, 5-6; Bates, A Texas Cavalry Officer's Civil War, 22; "Letter from the Creek Nation," Van Buren Press, November 14, 1861 [letter dated November 7]. Col. Douglas Cooper's force consisted of his own $1^{\text {st }}$ Choctaw and Chickasaw Mounted Rifles, about 500 men of the $9^{\text {th }}$ Texas Cavalry commanded by Lt. Col. Quayle, Col. Daniel McIntosh's $1^{\text {st }}$ Creek Mounted Rifles, and the joint Creek-Seminole battalion under Lt. Col. Chilly McIntosh (Creek) and Major John Jumper (Seminole). 
Kansas was a smart move either way: if reinforcements were en route, Opothleyahola could link up with them sooner, but if Opothleyahola was on his own, he and his followers would be nearer to the relative safety of Kansas. Second, with thousands of mouths — civilian and warrior aliketo feed, forage and sustenance may well have become problematic. Moving north into fresh territory would've eased logistical concerns. Third, given the widespread sympathies within the Creek, Seminole, and even Cherokee Nations towards Opothleyahola, he was surely apprised of Cooper's whereabouts and actions. The old chief undoubtedly knew the Confederates were finally mobilizing to take the offensive, and he may well have known about the arrival of the $9^{\text {th }}$ Texas, too. Moving north away from Cooper may have been a practical move to avoid fighting a battle in the dead of winter. ${ }^{136}$

As Opothleyahola moved north, the Confederates quickly caught his trail and followed suit. The path of "Old Gouge" wasn't hard to find; the rebellious Indians left "a trail as large as a common stage road," "well beaten and plainly marked, a "distance of several miles in width." Moreover, Opothleyahola's followers left a barren landscape in their wake. As George Griscom scrawled in his diary, Opothleyahola moved north, "burning \& destroying the country as he goes - we get no feed for our hoses [horses] scarcely and but a little corn \& not much grass." Opothleyahola's followers were lighting the prairies ablaze to keep the Confederate's horses hungry. ${ }^{137}$

As the Rebel troopers kept on Opothleyahola's trail, they began finding "fires while yet burning," and "videtts [videttes; mounted scouts] of the enemy were nearly always to be seen in front to the right or left and occasionally to the rear.” Lt. Colonel Quayle informed his men in the

\footnotetext{
${ }^{136}$ ], "Letter from the Creek Nation," Van Buren Press, November 14, 1861 [letter dated November 7]; Bates, Texas Cavalry Officer's Civil War, 24; Griscom Papers, Briscoe Center, University of Texas-Austin.

${ }^{137}$ Griscom Papers, Briscoe Center, University of Texas-Austin. A.W. Sparks, As I Saw It, 30-31.
} 
$9^{\text {th }}$ Texas that they "were to march after the enemy until overtaken and beaten." Lt. Colonel Quayle of the $9^{\text {th }}$ Texas ordered blue and red strings tied around every man's left arm, including the arms of the Indians. Since the "motley assembly" of Confederates contained men in uniforms of every description, the strings were meant to tell friend from foe. Further, Quayle warned the Texans that Opothleyahola's men would "wear a piece of corn shuck." The Confederates were closing in on Opothleyahola and battle loomed. ${ }^{138}$

On November 19, 1861, the Confederates finally caught up to the old Creek chieftain near the Red Fork of the Arkansas River; in the afternoon, smoke from his campfires dotted the sky and several prisoners were taken. Opothleyahola's scouts were seen on the horizon. Anxious to close with the enemy, Lt. Col. Quayle of the $9^{\text {th }}$ Texas impetuously charged ahead, only to find the camp "recently deserted." Spotting more enemy scouts on the horizon and sure they were close, several companies of Texans ploughed onwards "at a furious rate" across four miles of open prairie as the sun began to set. As the Texan companies charged ahead of the rest of their regiment, Col. Cooper arrived on the field and ordered the remainder of the $9^{\text {th }}$ Texas and his own Choctaws and Chickasaws to halt. Assuming it was too dark to continue, Col. Cooper ordered the men to fall back to a nearby creek and make camp. ${ }^{139}$

Meanwhile, the detachment of Texan cavalry charging onward managed to find Opothleyahola's army. The rebellious Indians sat ensconced on two round hills amid a belt of timber, the whole position in the shape of a "horseshoe," in front of which lay the prairie across which the Texans had been charging. As the Texans came upon the position, Captain Brinson of Company D, perhaps not realizing he had stumbled across the entire enemy force of several

${ }^{138}$ A.W. Sparks, As I Saw It, 27.

139 "Report of Col. Douglas H. Cooper," January 20, 1862, Official Records., vol. 8, 5-6; George Griscom, Fighting With Ross' Texas Cavalry, C.S.A., 7. 
thousand, bravely and foolishly "charge'd \& came into line in fine style" with about 75 men. As Brinson's men charged forward, Opothleyahola's warriors let loose a "a pony chased by dogs," hoping to stampede the Texans' horses. The Texan horses remained steady, but several of Texans fired at the dogs. As the charging Texans swept close to the enemy, perhaps as close as 50 yards, the Indians unleashed "a volley of balls and arrows" from the concealment of the timber. The Texans could see the Indians "when they raised to fire upon us," and returned fire.

As this small company of Texans made their grand charge into the "nick" of the prairie within the Indian position, the other companies of the $9^{\text {th }}$ Texas present now swung into action. The Texans, who probably numbered now more than 300 , found themselves in a precarious position. Benjamin Vines later wrote to his wife, "We was surrounded with Creaks [sic] except one little space where we marched. It was in the shape of a horse shoe nyer [nearer] than any comparison then [sic] I can make. The enemy was discharging their guns from every side except the side in which we marched in at." As arrows and bullets flew in from three sides, Opothleyahola's warrior set fire to the prairie "in a half Dozen places affording them light to fight by."

Nearly surrounded, heavily outnumbered, the Texans fell back several hundred yards. During this first retreat, Captain Charles Stewart of Company ordered his men to halt and brought his pistol up to fire. He was struck by a ball in the head, "made an unusual noise," and fell slowly off his horse, the pistol discharging as he fell. The round from Stewart's pistol "passed very close" to the face of young Allison Sparks, whose sleeve and collar were covered with "a large wad of his brain." Benjamin Vines also witnessed the incident, and wrote that "the last words we heard him say was 'form on me boys." The skirmish continued in the twilight of dusk, the flickering prairie fires casting shadows across the long grass. Ben Vines fired "as fast 
as I could load," and took "good aim by the fire lights," sure that "my old musket called several of them." 140

As the Texans blundered into the clever ambush set by Opothleyahola, Col. Cooper in the rear learned of the Texas companies' discovery of the enemy. He hastily organized his command, including the other half of the $9^{\text {th }}$ Texas Cavalry, who had just taken off their saddle when the order came to mount up and ride. The Choctaws and Chickasaws moved out first, reached the battlefield quickly, and promptly struck the enemy; "a bloody fight of 15 minutes" ensued. The Texan companies already engaged with the enemy heard a "loud roar [which] told us of our relief and we thought thank 'God' as we passed through the line," the Texans "fell back on the Choctaws." The Texans watched the Choctaws and Chickasaws go forward into the short, "very severe" fight. Around this time, Company D of the $9^{\text {th }}$ Texas, who had performed the daring charge to open the engagement, now accomplished another spectacular feat by forming a square - a tactic little used on the battlefield. Sergeant George Griscom, the adjutant of the company, wrote proudly in the margins of his diary, "Regt forms a hollow square, Adjt performing the feat."

The remaining companies of the $9^{\text {th }}$ Texas also arrived on the field shortly after the Choctaws and Chickasaws charged in, and the Texans likewise "went out to the prairie and formed into line of battle." Yet the sky had grown so dark that James Bates complained "we could not distinguish an Indian from a white man [at] three paces..."it was impossible for us to tell even in daylight which of the Indians were our friends and which our enemies." Private William Coffman disliked the feeling of helplessness that accompanied inaction: "I felt very

${ }^{140}$ A.W. Sparks, As I Saw It, 33-34; Benjamin Rush Vines to Wife, November 30, 1861, $9^{\text {th }}$ Texas Cavalry File, Benjamin Vines Letter File, Hill College Historical Research Center, Hillsboro, TX. 
much like shooting after I was shot at." The Texans could only look on and listen as the dueling camps of Indians fought one another in the darkness. ${ }^{141}$

The arrival of the Choctaws and Chickasaws seemed to have blunted Opothleyahola's warriors' success, and shortly thereafter they shrunk back into the darkness. Within minutes, the Battle of Round Mountain, the first major Civil War engagement in Indian Territory, was over. Despite the sharpness of the skirmish, Confederate casualties proved relatively light: six killed, five wounded and missing. Most of these casualties came from $9^{\text {th }}$ Texas Cavalry in the opening minutes of the fight. The casualties of Opothleyahola's command are harder to determine. Col. Cooper claimed that Gouge lost 110 men lost, but Cooper would prove to have a penchant for bloating enemy casualty figures, and considering the course of the engagement, this numbers seems exaggerated. A Texan major reported 61 enemy killed, a more reasonable figure. Ultimately, we will never know. ${ }^{142}$

Opothleyahola's performance at Round Mountain revealed the old chief possessed a sharp strategic and tactical mind. His decision to burn the prairie to deny the advancing Confederates forage was astute, and his attempt to stampede the enemy's horses by letting loose the pony chased by dogs clever. Opothleyahola's warriors occupied a strong defensive position tactically, and in all likelihood, the rebellious Indians planned the ambush that lured the $9^{\text {th }}$ Texas Cavalry straight into their "horseshoe." Lighting the prairie on fire not only provided the Indians with light, but the smoke and confusion likely aided their retreat as well. In sum, despite commanding an ad-hoc army of warriors from a dozen tribes, lacking proper arms and

\footnotetext{
${ }^{141}$ Warren Coffman to William Coffman, December 6, 1861, $9^{\text {th }}$ Texas Cavalry File, Warren Coffman Letter, Hill College Historical Research Center.

142 "Report of Col. Douglas H. Cooper," January 20, 1862, Official Records 8, 5-6; Griscom, Fighting With Ross' Texas Cavalry, 7; Bates, Texas Cavalry Officer's Civil War, 29-30. Bates suggests that 40 or 50 was a more realistic figure regarding the enemy's causalities.
} 
ammunition, possessing no training and little cohesion, Opothleyahola outsmarted Cooper and turned in a smart performance at Round Mountain as a commander. The Confederacy could only claim victory because the Opothleyahola retreated during the night, a decision probably driven by the necessity of protecting the thousands of civilian refugees accompanying his force. The strategic objective of defeating Opothleyahola or pushing him out of the country had not been accomplished; although Confederate newspapers spun the skirmish as a Rebel victory, the reality was evident in one observer's comment that "the whole thing has to be done over." 143

After a night spent sleeping in line with strong pickets on watch, the Confederates advanced at daylight on November 20 and entered the chieftain's abandoned camp. In his desire to quickly escape the enemy's reach, Opothleyahola left behind a dozen wagons loaded with sugar, salt, coffee, flour and other supplies. Oxen, cattle, sheep, over a hundred ponies, and several carriages were all found abandoned. More darkly, soldiers also uncovered the bodies of two Southern soldiers "taken prisoner by them \& beaten to death." George Griscom experienced "feeling for the $1^{\text {st }}$ time as one does when leaving comrades slain on the field" and witnessed Confederate "Creeks taking some scalps the $1^{\text {st }}$ I ever saw." Though a sharp but small skirmish, the ugliness of war was on full display. ${ }^{144}$

Notably silent in Confederate sources is any real discussion regarding for whom all these captured supplies were intended. While it was widely known that Opothleyahola was harboring large numbers of civilian refugees, Confederate commanders and soldiers alike expressed little remorse for driving these hapless civilian further from their homes. The large quantities of food and supplies captured after Round Mountain were just as certainly intended for the needs and

143 “A Brush with Opothlehola," Van Buren Press, December 5, 1861.

${ }^{144}$ Warren Coffman to William Coffman, $9^{\text {th }}$ Texas Cavalry File, Warren Coffman Letter File, Hill College Historical Research Center; Griscom Papers, Briscoe Center, University of Texas-Austin. 
wants of women and children as for old Gouge's warriors. By forcing Opothleyahola to abandon his supplies, the Confederate offensive was in turn inflicting suffering upon the civilians Opothleyahola harbored.

In the wake of the Battle of Round Mountain, the two sides were given an unexpected respite. General Ben McCulloch in Arkansas believed that Federal forces in southwest Missouri were preparing to attack. He requested that Col Cooper "take a position near the Arkansas line, so as to co-operate with him." Cooper, whose army occupied a landscape burnt by the enemy and devoid of forage, was perfectly willing to head eastward and give his command respite from campaigning. The whole command turned east and south and headed for Concharta near Fort Gibson on the Arkansas River, reaching that place on November 24. After several weeks of meager campaign rations, the men delightedly wolfed down biscuits, pork, and apples. The men took stock of their captured mounts, and Private Sparks noted that many soldiers named their new ponies "Gouge, in honor to his former associations." 145

This reprieve from campaigning proved temporary. The immediate Federal threat to northwest Arkansas failed to materialize. Moreover, despite several days' opportunity to escape north into Kansas, Opothleyahola chose to remain in Indian Territory. Having received an invitation from a "disaffected Cherokee," Opothleyahola's force moved east into the Cherokee Nation. No longer needed to support McCulloch, Cooper once more decided "to prosecute the operation against Hopoeithleyohola without delay and with the utmost energy." Cooper was also undoubtedly nervous about Opothleyahola striking out into Cherokee Nation. The Cherokees' loyalties to the South were tenuous, and Opothleyahola could not be allowed to establish himself

\footnotetext{
145 "Report of Col. Douglas H. Cooper," January 20, 1862, Official Records 8, 7; Bates, Texas Cavalry Officer's Civil War, 33-35; A.W. Sparks, As I Saw It, 38-39.
} 
in that country long for fear of splitting its populace. Thus, Cooper's command set out again on November 29; the Rebel forces were again comprised of the $1^{\text {st }}$ Choctaw and Chickasaw Mounted Rifles, the $1^{\text {st }}$ Creek Mounted Rifles, a battalion of Choctaws, and the $9^{\text {th }}$ Texas Cavalry. The Texans may not have been thrilled at the prospect of further service with Cooper. James Bates confided in his diary that "It is the prevailing opinion that Col Cooper is afraid of old Potheohola and wants us between him and danger." Also accompanying the Confederates were a sizable detachment of Colonel John Drew's $2^{\text {nd }}$ Cherokee Mounted Rifles, finally mustered in and ready to take the field. Included in Drew's ranks were more than a few members of the Keetowah Society, a Cherokee secret society whose stance against acculturation and slavery made them uneasy bedfellows with the rest of the Rebel soldiers in Cooper's command. ${ }^{146}$

Opothleyahola's decision not to retreat into Indian Territory in the wake of Round Mountain, despite having approximately two weeks to do so and having not received any Federal reinforcements, suggests the Creek chief was growing bolder and more confident. Undoubtedly, Opothleyahola found many sympathizers among the Cherokee, and he probably gained more followers by entering Cherokee lands. Fresh food and forage could be had. But Opothleyahola's move was also an offensive one; he knew full well that the Confederacy would once again strike at him, and his continued presence in the Territory invited further engagement.

As Opothleyahola's band moved into Cherokee Nation, they "committed outrages on Cherokee citizens," primarily by sacking the homes of several pro-Confederate locals. As Cooper's Confederates pursued Opothleyahola from the Creek Nation into Cherokee Nation, they found evidence of his vandalism. At one home, an observer found that the "Creeks have

\footnotetext{
146 “Report of Col. Douglas H. Cooper," January 20, 1862, Official Records 8, 7; Bates, A Texas Cavalry Officer's Civil War, 36; Gaines, Confederate Cherokees, 20.
} 
destroyed all his household property, what they did not take away they demolished, ripping open feather beds, smashing a clock, etc., and killed his hogs, not to eat, but wantonly, because he was warm instead of cold." George Griscom of the $9^{\text {th }}$ Texas came across the Perryman planation on the Arkansas River, "where we see some of the horrors of war in the ruined condition of things here the furniture and everything of value about the house is demolished." 147

On December 8, Confederate troopers caught up to Opothleyahola's forces along the banks of Bird Creek in Cherokee Nation. Learning that perhaps Opothleyahola possessed "a desire to make peace," Col. Cooper sent James Vann of the Cherokee regiment to the Creek warrior ensuring that "we did not desire the shedding of blood among the Indians" and proposing peace talks be held. James Vann, after his visit to Opothleyahola's camp, returned to Cooper at dusk with lamentable news. Contrary to reports, Opothleyahola had no intentions of buckling, and indeed, "his warriors, several thousand in number, were all painted for the fight" and intended to attack that night. James Bates reported an even worse account of events, writing in a letter home that "Opotheohola refused to treat and threatened to kill [Vann] if he did not join him." Vann apparently agreed but claimed he needed to go bring in his wife, thereby making his escape. Accord to Bates, "Van also reported that Optheohola intended attacking us that night and he had had from 7,000 to 10,000 warriors—all armed with rifles, six shooters and hatchets." Although Vann's account was undoubtedly exaggerated, it was sobering news. Given the months of failed negotiations with Opothleyahola, Cooper could not have been surprised that this eleventh hour attempt at armistice fell flat. There would be no peace among the Indians. But Opothleyahola's aggressive posturing was disconcerting. ${ }^{148}$

147 J.P. Evans to E. Evans, December 7, 1861, John Drew Papers, Helmerich Center, Gilcrease Institute; Griscom Papers, Briscoe Center, University of Texas, Austin.

148 "Report of Col. Douglas H. Cooper," January 20, 1862, Official Records 8, 7-8; Bates, Texas Cavalry Officer's Civil War, 42-43. 
Opothleyahola's continued defiance and reports of his vast army unnerved the Cherokees. Faced for the first time with battle, John Drew's regiment of Cherokees, "panicstricken...dispersed, leaving their tents standing, and in many instances their horses and guns.” As word spread that battle with Opothleyahola loomed, many traditionalist Cherokees grappled with the prospect of fighting Indians with whom they empathized. Exacerbating the situation were soldiers who belonged to the Keetowah Society, who were perhaps in contact with Opothleyahola's camp itself. The Keetowahs fanned the flames of panic, warning of an imminent attack and encouraging the traditionalist Indians to defect. Tying cornhusks to their hair (similar to the badge worn by the rebellious Indians at Round Mountain), the Keetowahs and others slipped away from Drew's camp during the night and joined their fellow traditionalists alongside Opothleyahola. When the defected Confederate Keetowahs met their Union counterparts, they exchanged passwords. "Who are you?" one would ask. "Tahlequah—who are you?" came the response. "I am Keetowah's son," was the final reply. Armed with such passwords and devices, Drew's regiment melted away “in less than 20 minutes." 149

John Drew's detachment of the $2^{\text {nd }}$ Cherokee Mounted Rifles numbered 480 men at the outset of the campaign in late November. By the end of the night only a few dozen men remained; the rest either fled in desertion or defected to Opothleyahola's ranks. It marked the only time in the Civil War that a Confederate regiment defected en masse to the Union side. More importantly, however, the defection of John Drew's Cherokees revealed the schism within the Cherokee Nation over secession and the war. Between Opothleyahola's band and Drew's

149 “Report of Col. Douglas H. Cooper," January 20, 1862, Official Records 8, 7-8; Gaines, Confederates Cherokees, 43-48; "Report of Col. John Drew," December 18, 1861, Official Records 8, 16-18; Bates, Texas Cavalry Officer's Civil War, 43. The chapter "Disgrace at Caving Banks" in W. Craig Gaines' Confederate Cherokees offers an excellent, detailed account of the defection of John Drew's regiment. Even before the defection, Unionist, Keetowah Cherokee had been stirring up trouble among the Confederate full-bloods. Ultimately, some 600 men of Drew's regiment would defect to Opothleyahola's ranks before the campaign ended. 
defectors, hundreds of Creek, Cherokees, and Seminoles were now ostensibly serving the Union cause by fighting the Confederacy. The treaties of alliance with the Confederate States, formed just months prior, were wilting; three of the Five Tribes were falling into their own intra-tribal civil wars. ${ }^{150}$

Surely this must have been an unnerving moment for Colonel Douglas Cooper. Opothleyahola was coming, and the Cherokees were gone. Luckily for Cooper, however, reports of Gouge's imminent attack proved false. Still, Cooper now knew that his enemy numbered over 2,000 warriors, and Cooper's command had shrunk by some 400 . Moreover, as at Round Mountain, Opothleyahola's warriors enjoyed a stronger tactical position. The rebellious Indians occupied high ground, with Bird Creek fronting the northern end of their line and several ravines guarding their southern flank.

On the morning of December 9, after spending an anxious night "quietly awaiting the enemy," Cooper wisely decided to withdraw south. Private Allison Sparks thought this a masterful bit of generalship by Cooper, believing southward march was a ruse "to call [Opothleyahola] from his mountain stronghold, so we could better get at him." Cooper did indeed send a Creek scouting party to "ascertain whether the enemy had come down from the mountains." Yet Cooper did not intend to fight at Bird Creek. He "thought our force too small since the desertion of the Cherokees to contend against Opotheohola," and wanted to move south to reestablish communications and gather reinforcements. ${ }^{151}$

\footnotetext{
${ }^{150}$ Gaines, Confederate Cherokees, 46, 125; Griscom Papers, Briscoe Center, University of Texas-Austin. Gaines places the number of Cherokees who stayed with Drew at 60, and he gives the names of twenty-nine of them. In his diary, Griscom recorded that Opothleyahola stated that Vann "would be released by furnishing 100 deserters for their rank \& upon a failure to fulfill the requisition his command would be surrounded" and destroyed. This panic and the subsequent desertion "left the Col with only about 3 Com offrs [officers] about 15 men."

151 "Report of Col. Douglas H. Cooper," January 20, 1862, Official Records 8, 7-8; Sparks, As I Saw It, 43; Bates, Texas Cavalry Officer's Civil War, 43.
} 
Opothleyahola, positioned on the west side of Bird Creek, expected Cooper to ford Bird Creek and attack. As the Confederates marched south, parallel to Opothleyahola's lines but clearly with no intentions of taking the offensive, the rebel Indians took matters into their own hands. As the Confederates tramped south, the Confederate Creek scouts returned, reporting that Opothleyahola's force was on Bird Creek in large numbers ahead of the column. Almost simultaneously, the sharp report of guns was heard to the rear. Nearly 200 enemy warriors attacked Cooper's rear guard as he marched south, a "feint," meant to "draw us down to their desire and selected place" for battle. Opothleyahola was forcing a fight at Bird Creek. ${ }^{152}$

To Douglas Cooper's credit, the Confederate commander responded to the threat quickly and decisively. Cooper sent Captain R.A. Young's company of the $1^{\text {st }}$ Choctaw and Chickasaw in pursuit of the enemy marauders who struck the rear guard. Young chased the fleeing enemy nearly two miles before losing them in the swampy brush along Bird Creek. Meanwhile, Cooper "gave the order to "right about"” and formed his entire command three columns facing west to towards Bird Creek and Opothleyahola's army: the Choctaws and Chickasaws on the right (with whom Young's company would link up), the Texans and Drew's small band of steadfast Cherokees in the center, and the Creeks to the left. Cooper sent these men forward "at a quick gallop," and the Confederates went forward to clash with wily old Opothleyahola yet again. ${ }^{153}$

The Battle of Chusto-Talasah developed along two fronts. The heart of Opothleyahola's position rested along the northern end of the field, along the banks of a steep, horseshoe bend in Bird Creek 400-500 yards wide, convexly protruding west into the prairie. The bend proved

152 “Report of Col. Douglas H. Cooper," January 20, 1862, Official Records 8, 8; Griscom Papers, Briscoe Center, University of Texas-Austin; Bates, Texas Cavalry Officer's Civil War, 4345; "Report of Col. D.N. McIntosh,” December 16, 1861, Official Records 8, 16.

153 “Report of Col. Douglas H. Cooper," January 20, 1862, Official Records 8, 8; Bates, Texas Cavalry Officer's Civil War, 43. 
"densely covered with heavy timber, matted undergrowth, and thickets, and fortified additionally with prostrate logs." A small clearing rested in the center of the bend, wherein sat a house, a corn crib, and a rail fence, destined to become the vortex of the fighting. Bird Creek itself was "deep" and "fordable but at certain points known only to the enemy." On the east bank of the creek nearer the Confederates, the banks of the stream were cut by 30 foot bluffs, and both sides of the creek were densely wooded. While Opothleyahola's warriors lurked on both banks of Bird Creek around the horseshoe bend, the rebellious Indians' line also extended over a mile to the south, where another large contingent of Opothleyahola's warriors occupied a lower, straighter stretch of Bird Creek and a number of ravines that extended east in front of the creek, out into the open prairie south of the horseshoe bend. As James Bates estimated, the Loyal Indians' "main force was on each wing." 154

The battle opened to the south as Daniel McIntosh's Creeks to the left and a portion of the $9^{\text {th }}$ Texas Cavalry under Col. William Sims surged forward across the open prairie to strike Opothleyahola's right flank along the ravines and timber of Bird Creek's. The fighting began slowly, cautiously "like warning drops of rain before a shower." As the Confederate Creeks and Texans pushed forward, the Texans dismounted as the pace of fire quickened. James Bates experienced combat for the first time, and wrote home to his mother, "After the first excitement was over — the first few rounds fired - I ceased to have any apprehension whatever of danger." He quickly learned to distinguish the sound of smoothbore and Minie bullets. He also discovered that an "arrow produces a sound something like a bird flying swiftly through the air."155

154 “Report of Col. Douglas H. Cooper," January 20, 1862, Official Records 8, 8; Bates, Texas Cavalry Officer's Civil War, 45-46. The engagement at Bird Creek holds a number of names, the most prominent being the Battle of Chusto-Talasah or the Battle of Caving Banks. The Creeks called the place Fonta-hulwache or Little High Shoals.

${ }^{155}$ Bates, Texas Cavalry Officer's Civil War, 46-47. 
James Bates had plenty of opportunities to hone his acoustic understanding of warfare as the Texans, Confederate Creeks, and their rebellious counterparts clashed amid the ravines and timber. "One volley followed another in such quick succession that one continuous roar was kept up." For approximately an hour the two sides blasted away at one another, but finally Daniel McIntosh's Creeks managed to get in among their enemy counterparts and "met them in hand-tohand encounter," "making desperate charges...using their knives and the butts of their guns." The two opposing parties of Creeks, just months before united and now driven to fratricide, struggled for life and death among the thickets and trees. The Confederates finally drove Opothleyahola's warriors out of the timber back across Bird Creek. The rebellious Indians reappeared briefly upstream, but a final, bloodless Texan charge "routed them completely." Col. Daniel McIntosh crowed that his Confederate Creeks, "without any exception, fought bravely...charged upon the enemy and drove them out of their strong fortified place.” The Creeks and Texans owned the southern part of the battlefield. ${ }^{156}$

Things were proving more difficult for Confederate forces further north, tasked with piercing the seemingly impregnable, fortified horseshoe bend held by Opothleyahola's warriors. At the outset of the battle, as Captain Young's company chased away the Creeks who had attacked the rearguard, the rest of the Choctaw and Chickasaw Regiment formed up and rode across the open prairie towards Bird Creek. Owing "to the great difference in their horses and ponies," the regiment's rapid advance became rather disjointed. Thus the Choctaws and Chickasaws came upon Bird Creek piecemeal and across a broad front. Dismounting as they reached the timber and brush along the east bank of the creek, some companies made it to

\footnotetext{
${ }^{156}$ Bates, Texas Cavalry Officer's Civil War, 45-46; ; "Report of Col. Douglas H. Cooper,” January 20, 1862, and "Report of Col. D.N. McIntosh," December 16, 1861, Official Records, vol. 8, 9, 16; Van Buren Press [Van Buren, AR], "Letter from the Creek Nation," January 2, 1862 [letter dated December 20, 1861].
} 
water's edge without finding the enemy. Captain Jackson's McCurtain's men were not so fortunate. His dismounted troopers "commenced firing on the enemy" as soon as they reached the creek, and as they shifted south along the creek's edge, they came across the small clearing with the small house. "[T]he front of the house was crowded by the enemy," and the Confederates opened up a brisk fire. The other portion of the $9^{\text {th }}$ Texas, under Lt. Col. Quayle, assisted the Choctaws and Chickasaws in the attacks on the creek. The engagement spread "all along the creek," and other Choctaws and Chickasaws still searching for foes to fight in the brush were drawn to the growing sound of battle. ${ }^{157}$

From this opening phase of the battle, a rearranging of the Confederate line brought the battle to a climax around the horseshoe bend. Lt. Col. Quayle's Texans, who had been fighting to the left of the Choctaws and Chickasaws, swung around their allies' right, where they discovered a ravine to the north that led into Bird Creek. McIntosh's Creeks and Col. Sims' Texans, having successfully "dispersed" the rebellious Indians on the southern end of the line, "mounted our horses and galloped to the assistance of our friends above." Col. Sims' Texans moved to the far north and reunited with the rest of their command fighting around the ravine on the far northern end of Opothleyahola's line. James Bates was surprised to "find them engaged in a contest more fierce if possible than ours had been." The reunited Texans had to attack the ravine across open prairie, and they "were exposed to a heavy fire untill we succeeded in drivin them from a ravine running nearly parallel with the creek." Finally captured, the northern ravine offered "some degree" of shelter while the two sides exchanged fire. ${ }^{158}$

157 "Report of Col. Douglas H. Cooper," January 20, 1862, "Report of Captain Joseph Hall," "Report of Capt. R.A.Young," "Report of Captain Jackson McCurtain," January 18, 1862, and "Report of Captain William B. Pitchlynn,", Official Records, vol. 8, 15-21.

158 "Report of Col. Douglas H. Cooper," January 20, 1862, Official Records 8, 8; Bates, Texas Cavalry Officers Civil War, 46. 
The final struggle emerged in the late afternoon, as the impetuous Captain R.A. Young managed to lead his troopers across Bird Creek and captured the house in the center of the horseshoe bend. Sensing victory, the Choctaws and Chickasaws surged forwards several hundred yards into the brush; in their spontaneity, the Confederates had charged too far forward, and Young's company was raked with fire from the front and flanks as they fell back. Cooper's men charged forward yet again, only to once more be forced back. The "fight raged with the greatest fury" at close quarters, Opothleyahola's men "alternately yielding and advancing and pouring upon our troops a galling fire." On a third attempt, the Confederates managed to hold the house, and Daniel McIntosh's Creeks arrived "to the relief of the exhausted men of the Choctaw and Chickasaw regiment" and made one final attack upon the enemy in the heart of the horseshoe bend. ${ }^{159}$

After nearly four hours of intense fighting, the battle stumbled to a sudden conclusion. Colonel Cooper reported that in the wake of Daniel McIntosh's final assault, Opothleyahola's warriors "disappeared from our entire front." Moreover, there were reports of enemy warriors threatening the Confederates' baggage and horses in the rear, ammunition was running low, and the sun setting. Col. Cooper ordered his men to withdraw. For James Bates and the $9^{\text {th }}$ Texas Cavalry still engaged along the ravine to the north, however, the battle hardly felt decided. As the sun set, the Texans were ordered to retreat, an order obeyed with "some reluctance." Bates felt confident that with "one more hour of daylight we would have routed them completely." "As it was," Bates penned to his mother, "we were forced to leave the enemy in possession of part of the field and though others think differently I can't call our victory complete." 160

159 “Report of Col. Douglas H. Cooper," January 20, 1862, Official Records 8, 10; Bates, Texas Cavalry Officer's Civil War, 44.

160 "Report of Col. Douglas H. Cooper," January 20, 1862, Official Records 8, 10; Bates, Texas Cavalry Officer's Civil War, 44. 
The affair at Round Mountain constituted a sharp skirmish; by comparison, the engagement at Chusto-Talasah proved a true battle, with thousands of men fully engaged for nearly four hours along a mile and a half front. The Confederate forces, numbering 1,100 after the desertion of John Drew's Cherkoee, suffered 15 killed and 37 wounded. Opothleyahola's ranks probably contained between 2,500 and 3,000 warriors, but perhaps were as large as 4,000. Once again, Col. Cooper reported an inflated casualty count of the enemy's losses, claiming old Gouge lost 500 men. Considering the course of the battle, James Bates' recorded estimate of 150 enemy killed was likely nearer to the truth. ${ }^{161}$

Given the circumstances, both Opothleyahola and Col. Cooper performed admirably at Chusto-Talasah. As at Round Mountain, Opothleyahola managed to dictate the battle's placement, and once again, his tactical positions were superb. Positioning his troops along the horseshoe bend - long a favored Creek tactic_-gave his warriors a strong defensive position from which to fight. His warriors utilized timber and thickets, creeks and ravines to their advantage. As one Confederate Choctaw captain complained after the battle, "The mode of warfare adopted by the enemy compelled us...to abandon strict military discipline and make use of somewhat similar movements in order to be successful." Confederate cavalry was forced to dismount and fight a confusing battle on terms that favored the enemy. That a battle even took

\footnotetext{
161 "Report of Col. Douglas H. Cooper,” January 20, 1862, Official Records 8, 10-11. Col. Cooper's official report stated Opothleyahola's force "was certainly over 2,500," and he noted that prisoners and other officer estimates put the enemy's size at 4,000. Col. William Sims of the $9^{\text {th }}$ Texas supposed the enemy "amounted to about 2,500 or 3,000 men." James Bates put a "low estimate" of the enemy's ranks at 1,500, and George Griscom recorded in his diary the enemy was "near 4000 strong." These estimates indicate that Opothleyahola's army was considerably larger at Chusto-Talasah in December than at Round Mountain in November, when his army's size was estimated at 1,500. There are a few possible explanations for the varying size of Loyal Indians' forces. First, the affair at Round Mountain was brief in time and limited in scope; it's possible Confederates underestimated the size of the enemy's forces, or that not all of Opothleyahola's forces were engaged. Second, it's possible — even probable - that Opothleyahola's army grew in size prior to Chustenahlah. After the affair at Round Mountain and Cooper's retreat to the Arkansas River, Opothleyahola's confidence seems to have swelled; perhaps Indian confidence in him also grew, leading to more Indians joining his forces. Third, Opothleyahola's ranks grew immediately prior to Chusto-Talasah as many (perhaps even several hundred) of John Drew's men went over to the enemy.
} 
place under such lopsided tactical constraints can also be credited to Opothleyahola; the Loyal Indians' attack upon the Confederate rear guard instigated the general engagement Opothleyahola wanted, while allowing the chief to retain his defensive positions tactically. As Douglas Cooper and his troopers were painfully learning, Opothleyahola and his army were not to be underestimated. ${ }^{162}$

Once again in the wake of a battle, Opothleyahola slipped away in the night. The camps of his civilian followers were nearby, and he probably had their protection in mind after a full day's fight. Yet Opothleyahola may also have understood how close his army came to defeat on December 9. The rebellious Indians lost their hold on the southern stretch of the creek early in the battle, and as the sun set, Opothleyahola's control of the horseshoe bend was tenuous at best. Despite the Loyal Indians' numerical superiority and strong defensive dispositions, the Confederates nearly managed to break their lines altogether.

As for Col. Cooper, his generalship at Chusto-Talasah likewise deserves a degree of commendation. Cooper was probably wise in his attempt to withdraw from the area after the defection of John Drew's Cherokees, and perhaps such a retreat was still possible even after the initial attack on his rear guard. Yet he acted decisively and aggressively in choosing to attack, and he managed to bring all of his small command into the fray. The Creeks and Texans secured the south end of the battlefield within an hour. On the northern end of the field, Cooper's own Choctaws and Chickasaws attacked in somewhat piecemeal fashion, but performed yeoman's work and bore the brunt of the fighting. Cooper personally led his men throughout the engagement; George Griscom admiringly wrote that "the men behaved well \& were cheered on

${ }^{162}$ Gaines, Confederate Cherokees, 50-51; "Report of William B. Pitchlynn,” January 18, 1862, Official Records 8, 21.The Battle of Horseshoe Bend, pitting rebellious Red Stick Creeks against Andrew Jackson's militia and Indian allies in 1814, is probably the most well-known instance of Creeks fortifying a bend in the river. 
by the Gallant Col Cooper who was ever present when the bullets flew the thickest, hat off encouraging his men." Cooper's decision to withdraw at sunset drew the contempt of James Bates, and perhaps it was an error on Cooper's part. But exhaustion, nightfall, and especially a shortage of ammunition were no minor impediments. Overall, Cooper turned in a competent, if not spectacular, performance. ${ }^{163}$

Although Douglas Cooper won the Battle of Chusto-Talasah, his strategic objective of quashing Opothleyahola's Rebellion remained unrealized. As at Round Mountain, holding the field of battle accomplished little. Despite two sustained efforts, the campaign against the Opothleyahola and the Loyal Indians was not faring well. Opothleyahola had proved a dangerous opponent, one who demonstrated increased confidence as he marched through Cherokee Nation and lashed out at Chusto-Talash. His army remained intact, and his continued presence in Cherokee Nation was both an embarrassment and a threat. Worse, the political situation among the Cherokees seemed to be deteriorating. Most of the Cherokees in John Drew's regiment revealed themselves to be Confederates in name only, unwilling to take up arms against their fellow traditionalist and Keetowah brethren. And although Cooper's command fought well at Chusto-Talasah, the disparity in numbers and defection of Drew's Cherokees dimmed the prospect of decisively defeating the Loyal Indians. As one observer lamented in the wake of Chusto-Talasah, "a winter campaign will now be necessary," further suggesting at least two regiments of infantry, one regiment of cavalry, and a battery of artillery necessary to make any future battle against Opothleyahola "successful and conclusive." In short, despite his efforts, Col. Cooper could not defeat Opothleyahola alone. ${ }^{164}$

163 Griscom Papers, Briscoe Center, University of Texas-Austin.

164 "Letter from the Creek Nation," Van Buren Press, January 2, 1862 [letter dated December 20, 1861]. 
Acknowledging his need for additional help, Cooper reached out to Colonel James McIntosh in Arkansas for assistance. James McQueen McIntosh, no relation to the Creek McIntosh clan, graduated last in his class from West Point in 1849. At the start of the war he joined the Confederate cause, quickly rising to the colonelcy of the $2^{\text {nd }}$ Arkansas Mounted Rifles. Aggressive, brave, and perhaps reckless, James McIntosh saw combat early in the war, leading a violent charge of Louisianans and his own Arkansans upon the Federal foe at Wilson's Creek. He was thought highly of by Arkansans and his troopers. In the winter of 1861-'62, General Benjamin McCulloch travelled to Richmond to secure supplies for his department. "[T]o the delight of all," McCulloch left McIntosh in charge of affairs in Indian Territory, and it was Col. James McIntosh who would come to Cooper's aid that winter. ${ }^{165}$

In the wake of Chusto-Talasah, Cooper's force had retired to Choska along the CherokeeCreek line. Cooper desired both reinforcements and resupply, but he also hoped that his presence would "counteract any movement among the people [Cherokees] in aid of Hopoeithleyohola and his Northern allies." Although Cooper already possessed the $9^{\text {th }}$ Texas Cavalry, the beleaguered Confederate colonel asked James McIntosh for "additional white force" to finally quash Opothleyahola and steady the politically wavering Cherokees. "The true men among the Cherokees," Cooper warned direly, "must be supported and protected or we shall lose the Indian Territory." Cooper received word from Colonel McIntosh that several Texan cavalry units were en route, along with orders for ammunition and supplies to be sent to Cooper's command. McIntosh "hoped with this additional force I [Cooper] would be able to march against Hopoeithleyohola with certainty of success." Cooper's plea for reinforcements was a tacit admission of his failures thus far. ${ }^{166}$

165 "Letter from the Creek Nation," Van Buren Press, January 2, 1862 [letter dated December 20, 1861].

${ }^{166}$ Douglas H. Cooper to James McIntosh, December 11, 1861, Official Records 8, 709. 
On December 17, James Bates prophesied, "Things are rapidly approaching a climax in this section..." The very same day, Col. James McIntosh trotted out of Van Buren, Arkansas at the head of 1,600 Texan and Arkansas horseman to "settle matters in the nation." Arriving at Fort Gibson in eastern Cherokee Nation on December 20, where the brash Confederate colonel met with a surprised Douglas Cooper. An ambitious man, Douglas Cooper was not pleased to discover that McIntosh had taken the field personally, and although McIntosh reinforced Cooper's command with a battalion of Texan cavalry, most of the white reinforcements stayed under McIntosh's personal control. James McIntosh likely saw an opportunity to garner glory in Indian Territory during Benjamin McCulloch's absence. McIntosh may also have harbored doubts about Douglas Cooper's ability to take care of the Indian problem himself. ${ }^{167}$

Despite Cooper's surprise at McIntosh's arrival, the two men worked out a strategy to entrap Opothleyahola in a wide pincer movement. McIntosh would move up the Verdigris River in the direction of Opothleyahola's camp, while Cooper would swing wide along the Arkansas River and attempt to get in the Loyal Indians' rear, cutting off any escape routes northward. McIntosh likewise recalled, "On account of the scarcity of forage it was mutually determined that either force should attack the enemy on sight."168

On December 22, James McIntosh departed Fort Gibson with 1,380 troopers, including portions of the $3^{\text {rd }}$ Texas Cavalry, the $6^{\text {th }}$ Texas Cavalry, the $11^{\text {th }}$ Texas Cavalry, an independent company of Texan scouts, and several hundred soldiers of McIntosh's own $2^{\text {nd }}$ Arkansas Mounted Rifles. Within a few days, McIntosh found himself close to Opothleyahola's trail. He also received word from Col. Cooper that Cooper's force was moving slowly, that "his (Colonel

167 "Report of Col. Douglas H. Cooper," January 20, 1862, Official Records 8, 10; "Report of Col. James McIntosh," January 1, 1862, Official Records 8, 22-25; Bates, Texas Cavalry Officer's Civil War, 53.

168 "Report of Col. James McIntosh," January 1, 1862, Official Records 8, 22-25. 
McIntosh's) well-appointed command was too fast for mine." Cooper did inform McIntosh, however, of Stand Watie's $2^{\text {nd }}$ Cherokee Mounted Rifles presence, and Cooper thought that Watie's men might be able to reinforce McIntosh prior to any engagement. ${ }^{169}$

On December 26, the day after McIntosh's troopers celebrated a bitterly cold Christmas, the Texan expedition finally located Opothleyahola's army along the banks of Shoal Creek in the Osage Hills of Cherokee Nation. McIntosh's command relied upon an Indian guide to help him find Old Gouge's camp, and upon his approach toward the enemy, McIntosh determined to strike the enemy promptly, regardless of the fact that neither Cooper's nor Watie's commands had arrived. The aggressive, brash West Point was ready to "settle matters" immediately. ${ }^{170}$

As the expedition's advance guard approached Opothleyahola's position, the troopers crossed Shoal Creek only to find themselves under "heavy and continuous firing" from a forested hilltop on their right. The battle was set to begin, and once again, Opothleyahola's warriors enjoyed a strong defensive position, positioned on hilltop with Shoal Creek skirting part of the hill's slopes. Halleck Tustenuggee's Seminole warriors were dismounted among the oak trees along the lowers slopes of the hill; "each tree on the hill-side screened a stalwart warrior." One Confederate trooper admiringly admitted, "their main army occupied a very strong position, fortified by nature on a high hill, a real breast work of rocks and standing trees." At the crest of the hill were Opothleyahola's Creeks, mounted on horseback and ready to sweep away the enemy. The rebellious Indians were ready for a fight, "barking like a dog howling like a wolf \&

169 "Report of Col. Douglas H. Cooper," January 20, 1862, Official Records 8, 10; “Report of Col. James McIntosh," January 1, 1862, Official Records 8, 22-25. Interestingly, on December 25, McIntosh's command observed a party of enemy scouts that neared the Texans' camp. McIntosh felt "satisfied that his party was endeavoring to lead us on a fruitless chase." Perhaps Opothleyahola hoped to goad his opponent into another Round Mountain style ambush. If so, McIntosh failed to take the bait.

170 "Report of Col. James McIntosh," January 1, 1862, Official Records 8, 22-25; Douglas John Cater, As It Was: Reminiscences of a Soldier of the Third Texas Cavalry and the Nineteenth Louisiana Infantry (Austin, TX: State House Press, 1990), 102-103. 
yelling and gobbling like a turkey," boldly daring the Texans to attack. McIntosh promptly obliged. ${ }^{171}$

McIntosh made his dispositions quickly. He ordered the $6^{\text {th }}$ Texas Cavalry to deploy right along the banks of Shoal Creek, then dismount, ford the creek, and attack the enemy hilltop on foot. The $3^{\text {rd }}$ Texas Cavalry, $2^{\text {nd }}$ Arkansas Mounted Rifles, and the independent Texan company crossed Shoal Creek to form the center of McIntosh's line, with the $11^{\text {th }}$ Texas Cavalry forded Shoal Creek and formed on the left. As the $6^{\text {th }}$ Texas moved downstream and began the process of fording Shoal Creek and at the base of the hill, the rest of the command dismounted prepared for a massive charge up the rocky slope into the center of Opothleyahola's line. "Bullets and arrows were coming pretty fast" as the Texans formed their lines, wrote Private Douglas Cater of the $3^{\text {rd }}$ Texas Cavalry. "A feather arrow passed in front of my face just before we were ordered to dismount," remembered Cater, "and produced a strange sensation in me." As Cater encountered Indian arrows and prepared to see battle for the first time, his fellow trooper Henry Miller openly wept upon learning his duty was to hold the horses in the rear. ${ }^{172}$

Around noon, the order to charge blared forth, and "one wild yell from a thousand throats burst upon the air, and the living mass hurled itself upon the foe." The dismounted Confederate troopers surged forward at the double-quick, "dashed up the sides of the mountain, over cover of trees and rocks, amid a shower of leaden hail from the enemy's rifles." The Indians fired "volley after volley of rifles and arrows" as the Texans scrambled over the rocks. As the Southerners made progress up the hill, the Seminoles fell back into Opothleyahola's mounted men, producing confusion. For a brief moment, the two sides collided at the summit of the hill, and "hand to

171 "Report of Col. James McIntosh,” January 1, 1862, Official Records 8, 22-25; Cater, As It Was, 103; Sam Love to sister, January [?], 1862, Cyrus, John, and Sam Love Letters, $6^{\text {th }}$ Texas Cavalry File, Hill College Historical Research Center.

172 “Report of Col. James McIntosh,” January 1, 1862, Official Records 8, 22-25; Cater, As It Was, 103. 
hand encounters became general along the whole line, and fearful and deadly strife ensued for a short time." The Texans "rushed over [the hill's] side with the irresistible force of a tornado, and swept everything before it." ${ }^{\prime 173}$

Unable to withstand the fierce frontal assault, the Loyal Indians tumbled back, retreating into "the rocky gorges and deep recesses of the mountains" behind them. The Confederates, instead of immediately pursuing, went back to their horses, remounted, and then took off in pursuit of their fleeing foe. "Some of those fellows," John Cater admitted, "were very brave and daring and would not leave, but continued to shoot. One big feather cap fellow stood out from the trees and continued shooting until he fell." Having emptied both shotgun barrels and a revolver at the brave Indian warrior, Cater thought he might've killed the man himself. ${ }^{174}$

The Texans pursued the enemy into the rocky ravines and thickets behind the hill. On the far left of the Rebel line, Col. Young's $11^{\text {th }}$ Texas Cavalry swung wide and "succeeded in cutting off many of the enemy." As the Texans pushed onward, they approached Opothleyahola's main encampment, and the Loyal Indians made final stand. Yet with their main force broken and scattered, Opothleyahola's Indians could not stop the Texan tide, and by 4 p.m. the Confederates "remained victors in the center of Hopoeithleyohola's camp." Under the direction of Colonel James McIntosh, the Confederates at the Battle of Chustenahlah accomplished what Douglas Cooper could not. Opothleyahola' Rebellion had been put down. The Confederates suffered 9 killed and 40 wounded in the four hour engagement; the Confederates placed the enemy's casualties at $250 .{ }^{175}$

\footnotetext{
${ }^{173}$ Cater, As It Was, 103; "Report of Col. James McIntosh," January 1, 1862, Official Records 8, 22-25; "Letter from Chustenahala," Van Buren Press, January 9, 1862 [letter dated December 27, 1861].

${ }^{174}$ Report of Col. James McIntosh," January 1, 1862, Official Records 8, 22-25; Cater, "As It Was," 103104. 104.

175 “Report of Col. James McIntosh,” January 1, 1862, Official Records 8, 22-25; Cater, “As It Was,” 103-
} 
As the Confederate regrouped, they took stock of what they had captured. As at Round Mountain, the loot at Chustenahlah included 30 wagons, 70 oxen, 500 ponies, hundreds of cattle, sheep, and plenty of provisions and property. Unlike previous engagements, however, the Confederates were now responsible for hundreds of captured Indians themselves, a testament to how disastrous the Confederate breakthrough had been for the Union forces. At least 160 women and children, 20 blacks, and one wounded warrior were captured by the Confederate forces. After the battle, John Miller recalled "the women and children, whose camps had been destroyed, hovering together, and freezing in the snow, while 'round them lay the bodies of children, and women with babies still clasped in their arms, frozen to death."176

Over the next week, Confederate forces pursued Opothleyahola's broken band almost to the Kansas line. James McIntosh's Texans, Col. Cooper's mixed Indian and white force, and Stand Watie's $2^{\text {nd }}$ Cherokee Mounted Rifles all took part in the hunt, continuing to kill and wound small numbers of Indians while also capturing prisoners and more supplies. Although unable to capture the bulk of Opothleyahola's band (which had probably fractured into several, if not dozens of parties), by hounding the enemy, close to one hundred more prisoners were captured, hundreds of cattle taken, a pair of wagons burned, and several more warriors killed and wounded. Finally satisfied that Opothleyahola had been permanently driven from the Territory into Kansas, the hunt was called off. Opothleyahola's Rebellion was broken and defeated. ${ }^{177}$

176 “Report of Col. James McIntosh,” January 1, 1862, Official Records 8, 22-25; Cater, “As It Was,” 103 104; John Miller diary, $6^{\text {th }}$ Texas Cavalry File, Hill College Historical Research Center. John Cater offers a much higher figure of 300 civilians captured. Cater also informs us that the captured blacks were taken to Fort Smith, where a return to slavery most likely awaited them.

177 “Report of Col. James McIntosh,” January 1, 1862, Official Records 8, 22-25 
While Confederates enjoyed their triumph, the sting of defeat for Opothleyahola's followers at Chustenahlah marked only the beginning of their sad saga. Unfortunately, few contemporary records exist detailing their journey north into Kansas, but close reading of Confederate sources and post-war interviews do provide some insight into their struggles. Although a reasonable estimate of Opothleyahola's total party approximates 5,000, it is unclear just how many made the final journey north to Kansas following the disaster at Chustenahlah. Colonel McIntosh thought old Gouge took "not more than 400 to 500 Creeks with him," though perhaps this estimate only referenced Opothleyahola's warriors. Considering the thousands of Creeks, Seminoles, defected Cherokees, and runaway slaves accompanying Opothleyahola, and the Confederates' capture of only several hundred Loyal Indians, it seems likely that several thousand Unionists ultimately made the trek. By late January, 1862, nearly 6,000 Indian refugees had taken shelter in Kansas, most of who journeyed to Kansas with Opothleyahola. While Chustenahlah dispersed the Loyal Indians, and perhaps persuaded some to come into the Confederate fold, it appears that most stayed true to their sentiments and accepted a Kansan exile. ${ }^{178}$

The journey north into Kansas by Opothleyahola's followers is one of the most heartbreaking, and relatively unknown, chapters of the Civil War. An exodus of immense suffering and fear, thousands of refugees were pushed from their homes to camps on the cold plains of Kansas. The Confederate pursuit of the Unionist Indians forced Gouge's followers to both fend off Confederate attacks on their rear guard and push onward at a quick pace. Jackman Pidgeon remembered the stories his mother Smaddie, a Creek Indian, told of their unhappy

178 "Report of Col. James McIntosh,” January 10, 1862, Official Records 8, 31; Hopoeithleyhohola [Opothleyahola] and Aluksustenuke [Halleck Tustenuggee] to Abraham Lincoln, January 28, 1862, Official Records 8,534 . 
journey north. "There were times, as she told," Pidgeon related, "when they were overtaken by their pursuers, those serving with the Confederates," but Opothleyahola's sheer numbers allowed his followers to fend off their attackers. At one point, Smaddie Pidgeon's party was overtaken by the Confederates, and warriors were forced to "check the rear attackers." Smaddie watched the subsequent fight unfold from a hilltop. "At dark, as the firing kept on, the scene...seemed to be like the flicker of fireflies, with reports of guns heard and flashes here and there of the shooting." These attacks caused the greatest panic. Ten-year old James Scott witnessed one such heartrending scene during a Confederate assault. "One time we saw a little baby on its blanket in the woods. Everyone was running because an attack was expected and no one had the time to stop and pick up the child. As it saw the people running by, the little child began to wave its little hands. The child had no knowledge that he had been deserted."179

These constant attacks, beyond exciting panic, fear, and suffering, also meant that wagons, cattle, and other much needed supplies often had to be abandoned in order to escape. James Scott recalled, "We faced many hardships, we were often without food, the children cried from weariness and the cold, we fled and left our wagons with much needed provisions, clothing and other necessities... When our provisions went low, some of the members of the tribe turned to eating horse flesh." Considering the dozens of wagons, large herds of cattle and sheep, and stockpiles of other sundry goods already abandoned in the aftermath of the battles in November and December, Opothleyahola's followers trekked north with very little. ${ }^{180}$

Other memories suggest incredible acts of brutality took place. "Some women carrying children would be overtaken by Confederate soldiers and the soldiers snatched the children from

\footnotetext{
${ }^{179}$ Interview with Jackman Pidgeon, February 21, 1938, IPP, WHC, OU; Interview with James Scott, March 29, 1937, IPP, WHC, OU.

${ }^{180}$ Interview with James Scott, March 29, 1937, IPP, WHC, OU.
} 
the arms of the mothers and smashed their heads against the trees." Missionary Stephen Foreman in the Cherokee Nation, wrote in his diary, "They [the Confederates] are just from Opothleyahotah's [sic] camp, whither they went to give him, as they said a brushing...It is estimated that they killed about two hundred prisoners, including some women and children." As Confederate troopers overran parties of rebellious Indians trying to escape to Kansas, the lines between civilian and soldier blurred. ${ }^{181}$

The environment proved almost as vicious a foe as the Rebel pursuers. Many Confederate accounts of the period reference the bitter cold and lack of forage. James Bates wrote of taking walks to keep warm in the night. "Cold enough to freeze my breath on my mustache," he complained in his diary. The "rough Broken" country was "very rugged," and would've proven difficult to traverse for civilians tramping on foot. Even James McIntosh noted in his official report that the Confederates, and hence also Opothleyahola's sad band, marched "on ground covered with snow and at other times facing the chilly blasts from the north." Creek Indian Lindy Scott was told stories of how "the leg, arm, toes or fingers of some of the Indians were lost by being frozen and they would have to be amputated in the best manner possible." The lack of clothing showed, too, as "many of the Indians [went] barefooted in the sleet and snow." 182 Arrival along the Verdigris River basin in Kansas offered shelter from the Confederates but not from the elements. Poor, handmade tents - stitched together with rags, handkerchiefs, anything - offered little protection from the snow and wind. When an army surgeon visited in February, he found seven children stark naked. Two thousand ponies died in the Kansas camps

\footnotetext{
${ }^{181}$ Interview with James Scott, March 29, 1937, IPP, WHC, OU; Stephen Foreman Papers, January 3, 1862, WHC, OU.

${ }^{182}$ Bates, Texas Cavalry Officer's Civil War, 61-62; Griscom, Fighting with Ross' Texas Cavalry Brigade, 11; “Report of James McIntosh,” January 1, 1862, Official Records 8, 24; Interview of Lindy Scott, October 29, 1937, IPP, WHC, OU.
} 
from the cold, and poor sanitation made the water "unfit for use." The refugees continued to suffer until their eventual removal to the land around LeRoy, Kansas, and the arrival of supplies from the United States. ${ }^{183}$

Thousands of Creeks, Seminoles, Cherokees, runaway slaves, men, women, children, and elderly made the three hundred mile exodus from Indian Territory to the Verdigris River in Kansas. Hounded by Rebel pursuers, whipped by the wind and cold, bereft of provisions or property, the journey exacted an unknown price, although surely hundreds perished along the way. Upon witnessing these refugees stumbled into their Kansan camps, Indian agent George Cutler simply stated, "I doubt much if history records an instance of sufferings equal to these."184

Born out of the fraudulence and intimidation with which the Confederacy conducted its affairs with Native Americans in Indian Territory, Opothleyahola's Rebellion constituted a massive uprising against both tribal governments and the Confederate States. Comprised of thousands of "civilized" and "uncivilized" Indians, free blacks and runaway slaves, the rebellion challenged the fraudulent alliances forged by acculturated Native elites and the Confederacy, while in the process liberating African-Americans from the bonds of wealthy Indian slaveholders.

This immense affront to Confederate power and society did not go unchallenged, and despite overtures of peace, the Confederacy ultimately relied upon force to quash Opothleyahola's Rebellion. This task proved easier said than done, and Opothleyahola and his ad-hoc army demonstrated strategic and tactical brilliance throughout the winter campaign. Yet

${ }^{183}$ Debo, The Road to Disappearance, 151; George A. Cutler to William G. Coffin, September 30, 1862, Report of the Commissioner of Indian Affairs for the Year 1862: 139.

${ }^{184}$ George A. Cutler to William G. Coffin, September 30, 1862, Report of the Commissioner of Indian Affairs for the Year 1862, 139. 
at Chustenahlah, the rebellion's back was broken by the discipline of Texan troopers, and Opothleyahola's followers endured unimaginable tragedies as they battled Confederate foes, harsh environments, starvation and depredation on their long exodus to Kansas.

Two terrible ironies emerge from Opothleyahola's Rebellion. For Opothleyahola and his followers, the political rebellion begun in August was meant to keep Native Americans out of the Civil War. Yet by November and December, their rebellion turned violent, inaugurating a bloody Indian civil war throughout the Territory. The peace they hoped to keep was broken by their attempt to keep it. For the Confederacy, however, their victory in crushing Opothleyahola's Rebellion contained the seeds of their own destruction. When Opothleyahola's followers arrived in Kansas, they soon began clamoring to go home. The arrival of thousands of refugee Indians in Kansas forced the United States to finally turn its attention to Indian Territory, and it prompted the twin Federal invasions of the Territory in 1862 and 1863. In defeating and expelling Opothleyahola and his followers, the Confederates in Indian Territory were hastening the return of the United States. 


\section{“These Indians Say They Are Not Whipped Yet":}

\section{The Kansas Refugee Crisis and the Political Origins of the First Indian Expedition}

"I started for the camp of the southern refugee Indians, which were at the time located on the Verdigris; and, on reaching them, I found the terrible tale which had been told me most true, but only a shadow of what really existed." -George Cutler, Indian Agent, September 30, $1862^{185}$

In early February 1862, several inquiring newspapermen sallied forth from the small, central-Kansan town of Emporia to inspect a newly founded refugee camp five miles south along the Cottonwood River. The camp consisted of some 200 Native American refugees struggling to survive in the midst of an unusually harsh winter on the plains. "We found them," the Kansans reported, "suffering immeasurably from the cold." Their clothing was "thin, ragged and dirty," and the Indians lived in tents scraped together from wagon covers, buffalo hides, and old quilts. Though supplied with food, the reporters found six Indians sharing a single pot and spoon for their breakfast, which consisted of plain hominy. Although Emporia citizens charitably donated sundry goods to the Indians, which "seemed to please them 'muchly'," the Kansans admitted the "gifts did not go far in such a large crowd." "186

Hoping to learn more about their newfound neighbors, the newspapermen attempted to spark a conversation with the breakfasting Indians, but "very few of them can talk English and those who do are not inclined to be at all communicative." Still, the Kansans seemed to coax a conversation out of the forlorn natives. "Many of them are remnants of families broken up by the guns of the blood-thirsty Texan Rangers, and by murderous deeds of their own secession brethren...Parts of families were there who knew nothing of the fate of their nearest relatives,

\footnotetext{
185 George Cutler to William P. Dole, September 30, 1862, Annual Report of the Commissioner of Indian Affairs (Washington, D.C.: G.P.O., 1862), 138.

186 "Visit to the Indians," Emporia News [Emporia, KS], February 8, 1862.
} 
and sadness was depicted on many countenances." The Indians lamented the prosperous homes and burgeoning corn fields they left behind. "They loved freedom and the Union more than these, and for opinion's sake are made absolute beggars. What an example these red men have set for thousands of timid white men!" the Kansans concluded. "We hope the Government will do its duty toward these Indians, at an early day." 187

The refugee camp the Kansans investigated was one of many that dotted the southeastern Kansan plains beginning in the winter of 1862 . The inhabitants of the Cottonwood refugee camp were several hundred Creek Indians, followers of Opothleyahola who, in the wake of their decisive defeat at the Battle of Chustenahlah the previous December, were driven from Indian Territory into exile. Bereft of supplies, thousands of Native Americans trudged across the frozen plains to refugees camps like the Cottonwood throughout winter and spring. By April, 7,600 Indian refugees were spread across several hundred miles of southeastern Kansas, dependent upon the Office of Indian Affairs and charitable Kansans for survival. While recently scholarship has explored the experiences and agency of African-American and white Southern refugees, this chapter examines Native American refugees and their ability to shape Federal military policy. ${ }^{188}$ The failure of Opothleyahola's Rebellion in the cold winter of 1861 produced an immense refugee crisis in the hot spring of 1862 . These Indian refugees arrived in Kansas just as

187 "Visit to the Indians," Emporia News, February 8, 1862.

188 "Visit to the Indians," Emporia News, February 8, 1862; George A. Collamore to William P. Dole, April 21, 1862, Annual Report of the Commissioner of Indian Affairs (Washington, D.C.: G.P.O., 1862), 157. Amy Murrell Taylor's Embattled Freedom: Journeys through the Civil War's Slave Refugee Camps (Chapel Hill: University of North Carolina Press, 2018) and Chandra Manning's Troubled Refuge: Struggling for Freedom in the Civil War (New York: Alfred A. Knopf, 2016) both navigate the experiences of the 500,000 wartime AfricanAmerican refugees and argue that enslaved refugees fueled the United States' embrace of emancipation and enlistment of African-American soldiers. Mary Elizabeth Massey's dated Refugee Life in the Confederacy (Baton Rouge: Louisiana State University Press, 1964) examines the experiences of wealthy, white Southern refugees in anecdotal fashion. David Silkenat's Driven from Home: North Carolina's Civil War Refugee Crisis (Athens: University of Georgia Press, 2016) explores African-American, white Unionists, white Confederates, and school-age refugees in North Carolina, using that state as a case study to broaden our social, economic, and racial understanding of refugees. This chapter adds to that literature by investigating the conditions of Native American refugees in Kansas and their impact on regional military policy. 
the United States determined to mount a military expedition into Indian Territory. The Indian Expedition was the product of Kansan politics, refugee demands, and military necessity. Kansas politicians, notably Senator James Lane, desired a regional military expedition that would bring opportunities for field service and Federals funds to their corner of the war. While initially meant to return Federal authority to Indian Territory as military necessity, refugee Natives added a sense of moral urgency to the expedition. Despite their material destitution, refugee Loyal Indians and their agents wielded a considerable amount of agency and managed to add a new objective to the Indian Expedition: liberate Indian Territory to allow expatriated Loyal Indians to return home.

Moreover, Loyal Indians would accompany the Indian Expedition as members of the United States Indian Home Guard regiments. Just as runaway and refugee African-Americans convinced the United States to enlist their services, so too did refugee Native Americans break racial barriers by enlisting in the military. Ultimately, the origins of the Indian Expedition stemmed from the cutthroat world of Kansan politics, recognition of a military disaster in Indian Territory, and the demands of Native Americans clamoring to return home with guns in hand.

Even before word of Opothleyahola's Rebellion reached the North, the possibility of an Indian Expedition south into Indian Territory arose amidst the murky arena of Kansas politics. Rumors of a possible expedition south emanated from and circulated around one man: Kansas Senator James Lane. A well-known, polarizing entity in Kansas, Lane was a political and military opportunist who leveraged crises to his personal advantage. A one-time Democrat hailing from Indiana, Lane moved to Kansas during the violent days of "Bleeding Kansas," embraced militant abolitionism, and led Free-Soil "jayhawkers" through the conflict. His 
notoriety and ardent politicking awarded him a coveted position as one of Kansas' first Senators after statehood in 1861. At the outbreak of the Civil War, Lane raised a brigade of Kansan troops that quickly earned a reputation as an ill-disciplined force, plundering and pillaging among the slaveholding communities of western Missouri. Yet Lane possessed bigger aspirations, and any expedition from Kansas into the South—Indian Territory, Texas, Arkansas...anywherepromised a chance at greater military and public glory. ${ }^{189}$

During the autumn and winter of 1861-'62, Lane waged a political campaign to create a military department encompassing at least Kansas, Indian Territory, and Arkansas; Lane, of course, expected to head the department. Armed with such a command, Lane could launch an expedition south and earn glory on the battlefield. Lane first broached the idea with Abraham Lincoln in October of 1861, generously offering to command the department "and devote all my thoughts and energies to the prosecution of the war." Lane also met with the Loyal Indian delegation passing through Kansas in October, pitching the Indians on the possibility of a campaign southward. Although the government did indeed create a Department of Kansas (which also encompassed Indian Territory), Lincoln appointed General David Hunter rather than Senator James Lane to command it. Despite Washington's rejection of Lane's offer to take the field, by November rumors of "Lane's Expedition" were circulating through Kansas newspapers anyways. Angry at Hunter's appointment, Lane remained undeterred and continued playing a hand in Kansas military affairs. ${ }^{190}$

${ }^{189}$ David Nichols, Lincoln and the Indians: Civil War Policy and Politics (Columbia: University of Missouri Press, 1978), 34-41. Nichols' work offers an excellent overview of the corruption endemic to the "Indian system" in the first half of the $19^{\text {th }}$ century in his second chapter, "The Indian System". Nichols' book examines the Lincoln Administration's policies toward Indians, and he pays attention to affairs in Indian Territory, documenting treaty-making, enrollment of Indian soldiers, the First Indian Expedition, and more. Nichols acknowledges his emphasis on "Lincoln and his subordinates rather than the Indians themselves," making Nichols' work a useful but strictly top-down study of Indian policy primarily derived from government sources.

${ }_{190}$ J.H. Lane to Abraham Lincoln, October 9, 1861, Official Records 3, 529-530; Nichols, Lincoln and the Indians, 37-38; Robert Collins, Jim Lane: Scoundrel, Statesmen, Kansan (Gretna, LA: Pelican Publishing Co., 
While Lane promoted an expedition south and rumors floated around Kansas throughout the winter, the Lincoln Administration became increasingly concerned over the state of military affairs in Indian Territory. The Confederate-Indian alliances caught the administration off-guard, and they were similarly surprised to discover that the Confederacy was raising Native American regiments for field service. Washington, it seemed, expected the Indians to stay out of the Civil War. In his annual report to Congress on December 2, Abraham Lincoln addressed his growing concerns, admitting Indian Territory had been lost to "insurrectionists," and that the Confederacy was recruiting Indian soldiers. Lincoln, however, knew from correspondence with "several prominent chiefs" that many Indians remained loyal, "expressing a wish for the presence of federal troops to protect them. It is believed upon the repossession of the country by the federal forces the Indians will readily cease all hostile demonstrations, and resume their former relations to the government." Lincoln's December address to Congress indicated that Washington was finally taking stock of Confederate influence over Indian Territory, and Lincoln was prepared to mount and Indian Expedition to reassert Federal control. ${ }^{191}$

In late December, the Loyal Indian delegation of Creeks (including Oktaharsharjo), Seminoles, and Chickasaws finally arrived in Washington after months of travel. The Indians met with Commissioner of Indian Affairs William Dole and later Lincoln himself. During these meetings, the Indians — unaware of the outbreak of full rebellion back home - made clear that

2007), 193-195; Albert Castel, Civil War Kansas: Reaping the Whirlwind (1958, repr., Lawrence: University Press of Kansas, 1997), 78-79; "Interview with the Chiefs and Commissioner Dole," Lawrence Republican [Lawrence, KS], January 2, 1862. Lane and Lincoln had a positive relationship; as Albert Castel notes, Lane spent years “assiduously cultivating Lincoln's friendship." Lane's support of Lincoln's presidential campaign and his veryvisible role in protecting Washington, D.C. with his Kansan "Frontier Guard" in April of 1861 earned Lane a position as a Lincoln confident, and Lane used that connection to shape political and military affairs in Kansas. Castel, Civil War Kansas, 34-36.

191 "Interview with the Chiefs and Commissioner Dole," Lawrence Republican, January 2, 1862; "Annual Message to Congress," December 3, 1861, The Collected Works of Abraham Lincoln, ed. Roy P. Basler (New Brunswick, NJ: Rutgers University Press, 1953), 5:43. 
many in the Territory "look to the North and the treaties for help." Oktaharsharjo opined that, "A boy when he get into any difficulty, goes to his father, and we have come on here in our difficulty, to our Great Father. Now we are satisfied he was right, and that the South is wrong." Commissioner Dole declared to the native delegation, "You have seen in your travels the power of the North. This power will be used if necessary to defend your people, and to put down this armed rebellion against you and the Government. It may take time, but it will be done by the President." Upon inquiry, the Indians assured Dole that thousands of warriors would assist any expedition in Indian Territory. ${ }^{192}$

With James Lane needling for a campaign, Confederates solidifying control of Indian Territory, and an Indian delegation in Washington pleading for help, Lincoln acquiesced to an Indian Expedition. The expedition's goal was to regain control of Indian Territory and bring the rebellious Indians back under the control of existing Federal-Indian treaties. On January 4, the president also approved the enlistment of 4,000 Native American soldiers, whose enlistments would begin immediately. Thus by January of 1862, preparations for an Indian Expedition were underway. ${ }^{193}$

The Union's decision to invade Indian Territory in 1862 was made without reference to Opothleyahola's Rebellion in Creek and Cherokee Nations that winter. Indeed, by the New Year word of fighting in Indian Territory had hardly reached Kansas and the first pitiful Indian refugees were crossing the state line. Nevertheless, the failure of Opothleyahola's Rebellion and the resulting exile of his followers to Kansas produced an immense refugee crisis that could neither be ignored nor dismissed. Enduring suffering and death amid a cold winter with few

192 "Interview with the Chiefs and Commissioner Dole," Lawrence Republican, January 2, 1862.

${ }^{193}$; Nichols, Lincoln and the Indians, 39. 
provisions, the Indian refugees' constant demands for an expedition kept the project alive and altered the expedition's purpose. Thus, it is critical to understand the experience of Native Americans refugees in Kansas and the political pressure they brought to bear on Federal officials.

The decisive defeat of Opothleyahola's Rebellion at Chustenahlah in Cherokee Nation on December 26 sparked a sudden, desperate exodus northward by the Loyal Indians into Kansas. The rapid collapse of Opothleyhola's center during the battle left his followers little time to gather their belongings. Instead, they fled with "what they had on their backs" amidst "the wildest confusion." As the battle lines broke and the Loyal Indians retreated north, they fought not one but several opponents: Confederate pursuers, a blisteringly cold winter, and desperate lack of supplies. ${ }^{194}$

At first, Opothleyahola's followers simply sought to get away from their Confederate foes. The Creeks and Seminoles scattered into small bands, each improvising its own northerly escape. For several days after the battle, Confederates under victorious Col. James McIntosh, joined by Col. Douglas Cooper's and Col. Stand Watie's troopers, chased the Loyal Indians north. This aggressive pursuit of civilian parties forced the Indians to both fight constant rearguard actions against the Rebels while prompting them to pick up the pace. Jackman Pigeon remembered the stories his mother Smaddie, a Creek Indian, told of their unhappy journey north. "There were times, as she told," Pigeon related, "when they were overtaken by their pursuers, those serving with the Confederates," but Opothleyahola's sheer numbers allowed his followers to fend off their attackers. At one point, Smaddie Pigeon's party was overtaken by the Confederates, and warriors were forced to "check the rear attackers." Smaddie watched the 138-140.

${ }^{194}$ Report of George A. Cutler, September 30, 1862, Annual Report of the Commissioner of Indian Affairs, 
subsequent fight unfold from a hilltop. "At dark, as the firing kept on, the scene... seemed to be like the flicker of fireflies, with reports of guns heard and flashes here and there of the shooting." 195

These attacks caused confusion, and families became separated during the exodus and "knew nothing of the fate of their nearest relatives." While some escaped, others fell behind and were captured or killed, and acts of brutality took place. As James Scott recalled, "Some women carrying children would be overtaken by Confederate soldiers and the soldiers snatched the children from the arms of the mothers and smashed their heads against the trees." Stories of such cruelty migrated south as well as north. Watching Confederate troops return "from Opothleyahotah's [sic] camp, whither they went to give him, as they said a brushing," Cherokee missionary Stephen Foreman divulged to his diary, "It is estimated that they killed about two hundred prisoners, including some women and children." As Confederate troopers overran parties of rebellious Indians trying to escape to Kansas, the lines between civilian and soldier blurred. ${ }^{196}$

The Indians finally slipped through Confederate clutches as they neared the Kansas line, but as the human enemy faded, the winter foe reared its ugly head. The environment proved almost as vicious a foe as the Rebel pursuers. From their starting point at Chustenahlah in western Cherokee Nation, the Loyal Indians trekked in north-northeasterly direction toward the Verdigris River basin in southern Kansas. Over the course of several weeks, the scattered bands of refugees completed a march over three hundred miles "with a bitter northwest wind in their

\footnotetext{
195 Jackman Pigeon, interview by Billie Byrd, February 21, 1938, IPP, WHC, OU.

196 "Visit to the Indians," Emporia News, February 8, 1862; interview with James Scott, IPP, WHC, OU; Stephen Foreman Papers, Cherokee Nation Manuscript Collections, WHC, OU.
} 
faces." Unfortunately, the winter of 1861-1862 was deemed the "most severe that occurred in that part of the country for many years," and snow dusted the rolling plains. ${ }^{197}$

The lack of proper provisions compounded the dangers of the cold. The Indians' sudden flight left them bereft of basic supplies: clothing, shelter, or food. The Indians were "thinly clad," "barely sufficient to hide their nakedness," and "many of the Indians walked barefooted in the sleet and snow." Creek Indian Lindy Scott recalled "how the Indian followers of Opothle Yahola had to suffer much during the intense cold. The leg, arm, toes or fingers of some of the Indians were lost by being frozen and they would have to be amputated in the best manner possible." Tents and bedding had also been abandoned in the mad scramble after Chustenahlah, leaving the Indians exposed to winter winds and snow. "Women gave birth to their offspring upon the naked snow," one horrified Indian agent reported, "and in some cases the new-born infants died for want of clothing." Starvation stared many in the face. Wagons of provisions, herds of cattle and sheep all left behind meant Opothleyahola's followers trekked north with very little. James Scott remembered "We faced many hardships, we were often without food, the children cried from weariness and the cold, we fled and left our wagons with much needed provisions, clothing and other necessities... ${ }^{198}$

The dearth of sources regarding this sad exodus north keep much of it shrouded in mystery, and it is impossible to know with certainty how many Native Americans perished

${ }^{197}$ Report of William G. Coffin, October 15, 1862, and Report of George A. Cutler, September 30, 1862, Annual Report of the Commissioner of Indian Affairs, 135-140. During the pursuit of the fleeing Indians, Confederates also attested to the difficult conditions. James Bates complained in his diary, "Cold enough to freeze my breath on my mustache." George Griscom reported "rough Broken" and "very rugged" terrain. In his after-action report, Col. McIntosh reported his men (and thus Opothleyahola's band) marched "on ground covered with snow and at other times facing the chilly blasts from the north." Bates, Texas Cavalry Officer's Civil War, 61-62.

Griscom, Fighting with Ross' Texas Cavalry Brigade, 11; "Report of James McIntosh," January 1, 1862, Official Records, vol. 8, 24.

${ }^{198}$ Report of George A. Cutler, September 30, 1862, Report of William G. Coffin, October 15, 1862, and George W. Collamore to William P. Dole, April 21, 1862, Annual Report of the Commissioner of Indian Affairs, 135-140, 155-158; interview with Lindy Scott, IPP, WHC, OU; interview with James Scott, IPP, WHC, OU. 
winter. Given their destitute state and the thousands making the march, it seems probably the casualties reached into the hundreds. An Indian agent lamented that "quite a number of them froze to death on the route, and their bodies, with a shroud of snow, were left where they fell to feed the hungry wolves." ${ }^{\prime 199}$

While Creek, Seminole, and other Indian refugees trekked northward seeking safety, United States authorities in Kansas scrambled upon hearing word of the Indians' impending arrival. Indian agents and army officials alike were caught completely unprepared for this wave of migrants. The 1861 evacuation of Indian Territory by the U.S. Army and the subsequent Confederate-Indian treaties severed communication between U.S. Indian agents and their respective tribes. Confederate control of Indian Territory made the physical agencies inaccessible, and Southern Superintendent of Indian Affairs William Coffin gave the Five Tribes' Indian agents leave. When the Indian delegation led by Creek Chief Oktaharsharjo passed through Kansas in October, it gave Federal authorities some understanding of the Unionist sentiment among the tribes, but little could be done immediately. It was not until December that reports of violence in Indian Territory and the sudden "flight of the loyal Indians" northward forced Coffin to quickly mobilize his Indian agents. He ordered them to gather at Fort Roe, a small stockade on the Verdigris River in central Kansas, and it was to this location that the thousands of refugees from Opothleyahola's Rebellion fled. As they arrived, they "scattered over a territory 200 miles in extent on the bleak plains" into makeshift camps along the Verdigris and Fall Rivers. ${ }^{200}$ 138-140.

${ }^{199}$ Report of George A. Cutler, September 30, 1862, Annual Report of the Commissioner of Indian Affairs,

${ }^{200}$ Reports of William G. Coffin, October 15, 1862 and George A. Cutler, September 30, 1862 in Annual Report of the Commissioner of Indian Affairs (Washington, D.C.: G.P.O., 1862), 135-140; J.H. Lane, September 12, 1861, Official Records 3, 490. 
The arrival of Opothleyahola's followers and refugees from Indian Territory spawned a staggering refugee crisis in southern and central Kansas. By January of 1862, thousands of Native Americans were pouring into Kansan refugee camps daily. The Emporia News reported with some trepidation that "twelve thousand of these Indians are on their way to Kansas," and although the figure proved exaggerated, it was not far off the mark. In late January, Army surgeon A.B. Campbell placed the total number of Indian refugees at 4,500, though he noted "the number was being constantly augmented by the daily arrival of other camps and families." An army captain similarly reported close to 5,000 refugees but "calculated their numbers would swell to at least eight thousand, and probably ten thousand, men, women, children, and negroes." A fairly detailed, if unofficial, census of the refugees in early spring counted 5,000 Creeks, 1,096 Seminoles, 544 Yuchis, 315 Quapaws, 240 Cherokees, 197 Delawares, 140 Chickasaws, and smattering of individuals from other tribes, totaling 7,600 in all. Among the Creeks and Seminoles in particular, these numbers indicate massive population shift; by the spring of 1862 , over one-third of the Creek Nation (36.9\%) now resided in Kansan refugee camps. The rate proved worse for the Seminole; nearly half the tribe (48.6\%) took refuge in Kansas. The vast majority, though not all, of these refugees fought with Opothleyahola and fled north with him through the winter. ${ }^{201}$

201 "Indians on the Walnut," Emporia News, January 18, 1862; "News from the Indians," Emporia News, January 25, 1862; reports of A.B. Campbell, February 5, 1862, John Turner, February 11, 1862, George W. Collamore, April 21, 1862, and G.C. Snow, September 29, 1862 in Annual Report of the Commissioner of Indian Affairs (Washington, D.C.: G.P.O., 1862), 142-143, 151-158; Doran, "Population Statistics of Nineteenth-Century Indian Territory," 498. A.P. Campbell's January report included 3,168 Creeks, 53 Creek slaves, 38 free blacks, 777 Seminoles, 136 Quapaws, 50 Cherokee, and 31 Chickasaw. Other tribes documented among the refugees throughout the winter and spring included small numbers of Kickapoos, Caddoes, and Wichitas among others; the Emporia News reported the "remnants of nine different tribes" among the refugees. The Yuchi were a distinct tribe with historically close ties to the Creeks, and today are often members of the Muscogee (Creek) Nation.

Even Creek Indians who hadn't fought with Opothleyahola were sometimes driven north. Just a baby at war's outbreak, Creek Indian Eliza Bruner's family was at breakfast when "a raiding party came upon them." In their haste to flee, baby Eliza was left behind and taken by a man to Choctaw Nation. Fortunately, Eliza was reunited with her parents over two weeks at LeRoy, Kansas, indicating that the Creek family fled north in the wake 
The unrelenting flow of refugees, arriving at "twenty to sixty per day," and the unpreparedness of Federal officials meant that while Kansas offered protection from the Confederates, it initially provided protection from little else. The refugee camps quickly became centers of suffering, as hunger, cold, and disease took their toll. Indian agents, U.S. Army officers, and local Kansans were stunned by the condition of the refugees and the camps. Southern Superindent of Indian Affairs William Coffin admitted the "destitution, misery, and suffering amongst them [the Indians] is beyond the power of any pen to portray." Surgeon A.B. Campbell thought it "impossible for me to depict the wretchedness of their condition." The Indians lacked shelter and clothing, which exposed them to "the severe winds and rains, so common in Southern Kansas.” During a February visit, Surgeon Campbell found seven children "without one thread upon their bodies." A lack of food forced the refugees "to feed upon their ponies and dogs," but equally problematic was the lack of cooking utensils. Combined with a shortage of wood on the Kansan prairies, "many of them [the Indians] eat their provisions raw." 202

Unsurprisingly, exposure to the elements and the terrible condition of the refugee camps resulted in widespread sickness, disease, and death. Surgeon Campbell reported frostbite and foot injuries from the lack of shoes and "inflammatory diseases of the chest, throat and eyes." Others reported "consumption and pneumonia, brought on from exposure and privations of the common necessaries of life." One victim of illness was Opothleyahola's daughter, found dying of consumption. Over one hundred amputations had occurred by April, including one eight-year-

of the raid. Such incidents suggest how Indians who didn't accompany Opothleyahola directly nevertheless experienced violence and sought refuge in Kansas in 1861-1862. Interview with Walter Foster, IPP, WHC, OU.

${ }^{202}$ Reports of A.B. Campbell, February 5, 1862, W.G. Coffin, February 13, 1862 and October 15, 1862, George W. Collamore, April 21, 1862, Isaac Coleman, September 30, 1862, Annual Report of the Commissioner of Indian Affairs, 135-138, 145-147, 151-152. 
old Creek child who lost both feet. Some Indians' "frosted limbs rendered them unable to move about." Disgusted at the sights he witnessed, Campbell thundered that "common humanity demands that more should be done at once, to save them from total destruction." 203

The meager march north during the winter, exposure to the elements, and the ravages of deprivation and illness in the camp caused hundreds of death. The Creek Indian agent reported 240 deaths in his tribe by April; the total escalated almost 400 Creeks by September. The Seminole agent reported a ten percent mortality rate, noting that "most of their deaths, however, were caused from exposure while coming to Kansas last winter." In October of 1862, William G. Coffin, the Southern Superintendent of Indian Affairs, also placed the overall mortality rate among the refugees at ten percent, which may have constituted as many as 500-700 deaths. ${ }^{204}$

As the refugees staggered into the river basins of southern Kansas, Indian agents quickly made efforts to alleviate their suffering, with limited success. William G. Coffin, who oversaw the Indian agents to the Five Tribes, found himself "without adequate means to meet the emergency." He thus appealed to the General David Hunter, commander of the Department of Kansas, for assistance, and Hunter agreed to help. The Army provided what it could, but a more permanent, reliable source of provisions was needed. The Office of Indian Affairs thus turned to contractors to supply the Indians with necessary goods. Finally, local Kansans, moved by the plight of the Indians, also donated sundry goods to the refugees. ${ }^{205}$

The results of these efforts were decidedly mixed. Federal authorities were able to provide the Indians with rations and basic food items relatively quickly; by February local papers

${ }^{203}$ Report of A.B. Campbell, February 5, 1862, and George W. Collamore to William P. Dole, April 21, 1862; Annual Report of the Commissioner of Indian Affairs, 151-152, 155-158.

${ }^{204}$ Reports of George A. Cutler, September 30,1862, G.C. Snow, September 29, 1862; A.B. Campbell, February 5, 1862, Annual Report of the Commissioner of Indian Affairs, 138-140, 142-143, 151-152.

${ }^{205}$ Report of William G. Coffin, October 15, 1862, David Hunter to William P. Dole, February 6, 1862 
reported the Indians "have been relieved of from their starving condition." Yet the food provided was often meager, neither "sufficient in quantity or proper quality." Refugees subsisted off cornmeal, flour, beef, and a little salt. In one camp, Indians were provided one pound of flour and a little salt, which was meant to last the week. Other provisions, such as sugar, coffee, pepper and vinegar, were only available for the ill. Not only was food limited, but the Indians were likewise "extremely destitute of cooking utensils, and axes or hatchets," making it difficult to gather firewood and cook; "the want of cooking utensils compels many of them to eat their provisions raw.” The Indians didn’t starve in Kansas, but their subsistence was meager and economical. ${ }^{206}$ Other provisions, including cloth, shoes, tents, blankets, and other sundry goods, proved in shorter supply. In his visit to a refugee camp, Surgeon Campbell arrived with a wagonload of clothes and bedding. He circled the camp with his wagon, doling out the goods until they were gone and found himself "surrounded by hundreds of anxious faces, disappointed to find that nothing remained for them.” The two Emporia reporters who visited the camp on Cottonwood River brought "many articles, such as quilts, coats, pants, vests, boosts, shoes, etc.," but the supplies hardly met the demand. ${ }^{207}$

While Indian agents, military officials, and local white Kansans genuinely sought to assist the exile Native Americans, contractors quickly took advantage of the crisis to sell the Indians shoddy goods at high markups. This was not new. In the $19^{\text {th }}$ century, political patronage filled the Office of Indian Affairs with appointees who knew little (and often cared little) about Native affairs. Contracts and contractors experienced little oversight, and the "Indian system," as

${ }^{206}$ Emporia News, February 8, 1862; George W. Collamore to William P. Dole, April 21, 1862, Report of A.B. Campbell, February 5, 1862, Report of John Turner, February 11, 1862, Annual Report of the Commissioner of Indian Affairs, 151-158.

${ }^{207}$ Report of A.B. Campbell, February 5, 1862, Annual Report of the Commissioner of Indian Affairs, 151152; "Visit to the Indians," Emporia News, February 8, 1862. 
it was known, served as an avenue for corruption and fraud. Over the decades contractors and traders honed their swindling of Indians and the Office of Indian Affairs alike into a veritable art. The system was, as David Nichols has noted, "a system of, by, and for white men" who utilized it to empower and enrich themselves. ${ }^{208}$

Fraud plagued contractors' dealings with the Indian refugees in Kansas. Goods were not purchased by the tribes themselves or their agents, but rather jointly by specially appointed agent Dr. Kile and Southern Superintendent William Coffin. Thus, the Indians exercised no control over what was purchased on their behalf, nor at what price. This opened the door for contractors to sell the Indians inferior, shoddy goods at exorbitant markups. Instead of durable cloth or food, the Seminoles were delivered "fine delaines and unbleached muslins," completely "unsuitable" for refugees but nevertheless paid for at high prices. Making the best of the situation, the Seminoles sold off the expensive cloth at "one-fourth of their real value and cost" in exchange for more practicable "green corn, chicken, eggs, etc." One visitor to the Indian camps discovered the Indians were being furnished with bacon condemned at Fort Leavenworth, which they judged "unfit for a dog to eat." The refugees were likewise furnished with condemned army tents; given the shortage of shelter, however, the Indians nevertheless put the tents to good use. Overall, one Indian agent accused "that money annuities are much more to the benefit of a few avaricious and unscrupulous traders than to the Indians, and of much more benefit to a class of people who have too long been permitted to control their trade."209

However shoddy or inferior the food and provisions supplied by the contractors, it was all paid for by the Indians themselves. With thousands of refugees to feed and clothe, Congress

\footnotetext{
208 Nichols, Lincoln and the Indians, 24.

${ }^{209}$ Report of G.C. Snow, September 29, 1862, George W. Collamore to William P. Dole, April 21, 1862, Reports of George A. Cutler, September 30, 1862, Peter P. Elder, September 12, 1862, Annual Report of the Commissioner of Indian Affairs, 138-140, 142-145, 155-158.
} 
authorized tapping into the annuities owed the various tribes - held in arrears due to the rebellion and the divided loyalties of the Indians - to pay for the refugees' subsistence. It is not clear that the Indians' themselves were initially aware that their own annuities were being used to support them. Upon learning that they themselves were paying for their provisions, the Seminoles angrily complained to their Indian agent that the Federal government should foot the bill, since "they had not been protected according to treaty stipulations." The complaints yielded little effect. ${ }^{210}$

As spring dawned over the south Kansas plains, the refugees faced a new problem: dead horses. Despite the loss of much of their property, many of the refugees still managed to escape northward with roughly 4,000 horses and ponies in tow. Tired from the trek north, exposed to bitter cold, snow, and sleet, with no shelter, and little feed in the dead of winter, nearly half of the Indians' ponies "died of cold and hunger in and around their camps" over the course of the winter. Two thousand dead horses littered the prairies around the refugee encampments; several hundred carcasses choked streambeds and made water "unfit for use." While the weather was cold, the carcasses remained frozen. Yet as spring sun thawed the plains, the corpses thawed as well, posing health risks and creating an unbearable stench. Surgeon Campbell worried the carcasses would "breed a pestilence amongst them," and Indian agents understood the "indispensable" need to remove the tribes elsewhere. In March and April, the Indian agents oversaw the removal of the tribes from the Verdigris River toward the Neosho River basin to the east. Exiled from their homes after a long winter sojourn, once again the refugees packed up their meager belongings and moved thirty miles east to new encampments along the Neosho River. ${ }^{211}$

\footnotetext{
${ }^{210}$ Report of G.C. Snow, September 29, 1862, Annual Report of the Commissioner of Indian Affairs, 142143.

${ }^{211}$ Reports William G. Coffin, February 13, 1862 and October 15, 1862, A.B. Campbell, February 5, 1862, Annual Report of the Commissioner of Indian Affairs, 135-138, 145-147, 151-152.
} 
The relocation of the refugees to the Neosho brought new challenges. The refugees' initial encampments along the Verdigris River were located within lands reserved for various Indian tribes. There were relatively few white settlers in the area, and the Indians could encamp wherever suitable and draw upon natural resources as needed. The Neosho River Valley, however, did not sit on Indian lands, but rather "was mostly owned and occupied by [white] settlers." In particular, the Indians' new camps placed them near the small towns of LeRoy and Neosho Falls. Capt. John Turner, a commissary officer who worked with the Indian agents, took "very grave objection" to this relocation, prophesying, "No farmers would look with complacency or quietude upon such a crowd of destitute people brought around them, and I apprehend serious difficulties would arise.” In particular, Turner feared that Indians would strip the prairies of what little timber they possessed — timber which local farmers owned and "jealously" protected—and "commit great damages" to the countryside. Other Indian agents echoed Turner's concerns over possible disagreements among Indian refugees and white settlers and the issue of timber. ${ }^{212}$

Ultimately, these fears proved overblown. White settlers and Indian refugees made reasonable, if perhaps uncomfortable, neighbors. As Turner suspected, timber did prove to be an issue initially. The Creeks "did not fully understand the value of timber," and their agent George Cutler exerted a "vast amount of labor" to prevent them from denuding the area of trees. Yet the Creeks ultimately exercised restraint, and Cutler reported that "the general deportment of the Indians here has been good, and elicited the warmest encomiums of the whites." Agent George

\footnotetext{
212 John W. Turner to William P. Dole, February 11, 1862, Annual Report of the Commissioner of Indian Affairs, 152-154.
} 
Snow likewise testified to the good behavior and "utmost propriety" of the Seminoles. Native Americans and white Kansans managed the situation with aplomb. ${ }^{213}$

Given the deplorable condition of the refugee camps, the biting cold, the scarcity of supplies, the shady dealings with contractors, and yet another relocation to the Neosho River Valley, Native American refugees in Kansas unanimously expressed their desire to return home. They also demonstrated their willingness to fight within or alongside the Federal army in order to liberate their homeland. Native American refugees were instrumental to the formation of the First Indian Expedition and the enlistment of Native American soldiers into the Union army.

From the moment of their arrival in Kansas, Indian leaders and refugees alike clearly expressed their desire to return home. Having battled the Confederacy under Opothleyahola, they expected to march south soon with Federal soldiers at their side. On January 28, barely a month sent their defeat at Chustenahlah, Opothleyahola and Halleck Tustenuggee wrote to President Abraham Lincoln directly, detailing their suffering on the Kansas plains and begging Lincoln to "listen to the prayers of their children" and send an army south to "sweep the rebels before them like a terrible fire on the dry prairie." That same month, the Emporia News reported, "The Indians say that are not whipped yet, and are awaiting the marching of Lane's army, which they are anxious to join and go back and help fight to reclaim their homes." A few months later, Opothleyahola again audaciously declared to white visitors "that he and his people were willing, on being properly armed, to fight their own way back." Only when told of reports placing Confederate strength in the Territory at 5,000-6,000 did Opothleyahola concede "he would now

\footnotetext{
${ }^{213}$ Reports of George A. Cutler, September 30, 1862 and G.C. Snow, September 29, 1862, Annual Report of the Commissioner of Indian Affairs, 138-140, 142-143.
} 
require assistance from our troops." Despite being driven from their nations by force of arms, Native Americans refugees wished to return home and would fight to do so. ${ }^{214}$

Federal Indian agents agreed with their Indian charges. Throughout 1862, Federal Indian agents also pushed for the refugees to be returned south. "I would very respectfully recommend," George Cutler informed his superiors, "that they may be returned to their homes at the earliest practicable moment, both for the welfare of the Indians and as an advantage to the government." Yet Cutler warned that their return could not occur "until their country is completely rid of the rebels and a sufficient force can be left there to give them protection.” The Seminoles' Agent concurred, "[N]o time should be lost in taking them back to their country as soon as a sufficient force of the federal army can be stationed in the Indian Territory to protect them." 215

The terrible suffering of the refugees, their consistent demands to return home and their willingness to fight, and their support by Indian agents ultimately shaped the very purpose of the Indian Expedition. No longer was the expedition merely about reasserting military control over Indian Territory or bringing recalcitrant Indians into the fold. Instead, when the expedition finally marched in June, it was "especially intended to aid them [refugee Indians] to recover possession of their homes and to bring back the Indian country under subjugation to the Government." The expedition then, fulfilled the wishes of the Indians who wanted to go home and of the Federal government who no longer wanted to pay for their subsistence in Kansas. ${ }^{216}$

${ }^{214}$ Ho-po-eith-le-yo-ho-la and A-luk-tus-te-nu-ke to Abraham Lincoln, January 29, 1862, Official Records, vol. 8, 534; "Visit from the Indians," Emporia News, January 25, 1862; George W. Collamore to William P. Dole, April 21, 1862, Annual Report of the Commissioner of Indian Affairs, 155-158. In the same letter to Lincoln, Opothleyahola and Tustenuggee also asked that "'General Lane be placed in command of that expedition, as we believe no warrior can place us in possession of our country again as effectually as he can...General Lane is our friend. His heart is big for the Indian."

${ }^{215}$ Reports of George A. Cutler, September 30, 1862 and G.C. Snow, September 29, 1862, Annual Report of the Commissioner of Indian Affairs, 138-140, 142-143. Although these reports were written in the fall of 1862 (in the wake of the failed First Indian Expedition), there is no reason to believe the agents didn't support the Indians' return home in the previous spring.

${ }^{216}$ William Weer to Charles Doubleday, June 6, 1862, Official Records, vol. 13, 18-419. 
Just who would lead the expedition south, however, proved to be an issue of considerable drama. Throughout the spring, politics within the Army and within Kansas produced a revolving door of department and expedition commanders that delayed the expedition's start and ultimately left it in the hands of an inept Kansas politician-turned-general whose lackluster abilities would, in the end, endanger the entire operation.

When the expedition was initially approved in January, both General David Hunter and Senator James Lane angled to command it. Hunter commanded the Department of Kansas, but Lane's name had been attached to the expedition for some time. Although Lincoln offered Lane a military position within the department subordinate to Hunter, Lane continued to act as though he commanded the expedition. In an early January meeting with Secretary of War Cameron, Lane intimated that he was to lead an expedition of 30,000 soldiers south, and that he had David Hunter's support in the matter...a clear lie. Lane immediately wired David Hunter "it is the intention of the Government to order me to report to you for an active winter's campaign," a message which seemed to imply Lane would command the expedition. ${ }^{217}$

Lane's smoke and mirror politics frustrated Hunter, but they couldn't change the reality that David Hunter outranked him, and that Abraham Lincoln never intended Lane to supersede Hunter in command. An exasperated Lincoln wrote to Secretary of War Edwin Stanton on January 31 that "I have not intended, or do not intend that it [the expedition] shall be a great exhausting affair; but a snug, sober column of 10,000 or 15,000," a refutation of the 30,000 men supposedly destined for the expedition. Further, Lincoln made clear the chain of command. "Gen. Lane has been told by me many times that he is under the command of Gen. Hunter, and

\footnotetext{
${ }^{217}$ Simon Cameron to David Hunter, January 3, 1862, Official Records vol. 53, 512-513; James Lane to David Hunter, January 3, 1862, Official Records vol. 8, 482.
} 
assented to it as often as told. It was the distinct agreement between him \& men when I

appointed him, that he was to be under Hunter."218

In early February, Lincoln quashed the confusion by penning a joint letter to Hunter and Lane directly. Lincoln admitted he wanted "to avail the government of the service of both Gen. Hunter and Gen. Lane." Yet Lincoln explicitly stated that "Gen. Hunter is the senior officer, and must command when they serve together...Gen. Lane must report to Gen. Hunter for duty." If Lane couldn't agree to those terms, he must "decline the service." With cold, clear terms before him, Lane ran out of room for his ruses. He privately groused that Lincoln was " $d-d$ liar, a demagogue, and scoundrel" who betrayed a promise to make him major-general and left Lane looking like "a braggart, a fool, and a humbug." Although Lane relinquished his hopes of battlefield glory, he would continue to play a role in shaping Kansas’ military affairs. ${ }^{219}$

Ironically, despite all of James Lanes' intrigues and David Hunter's righteous protests, neither would command the First Indian Expedition. In March, the Army reorganized its geographical military departments and the Department of Kansas was subordinated under the larger Department of the Mississippi, commanded by General Henry Halleck. With his department downgraded, Hunter was sent east. He was replaced by Brigadier General John Denver. Halleck felt that Denver's prior experience as Kansas' territorial governor made him "best suited for the place," able to keep a handle on Kansas politics. Instead, Kansas politics kept a handle on John Denver. Senator James Lane disliked Denver and worried his appointment would limit Lane's import on military affairs. Consequently, Lane and his fellow Kansas Senator Samuel Pomeroy complained to Lincoln of Denver's posting. Lincoln intervened at Lane's

${ }^{218}$ Abraham Lincoln to Edwin M. Stanton, January 31, 1862, Collected Works of Abraham Lincoln 5, 115 116; Nichols, Lincoln and the Indians, 41; Collins, Jim Lane, 195-197.

${ }^{219}$ Abraham Lincoln to David Hunter and James H. Lane, February 10, 1862, Collected Works of Abraham Lincoln 5, 131; "Public and Private Opinion," White Cloud Kansas Chief [White Cloud, KS], July 3, 1862. 
request, and Denver was soon subordinated to Brigadier General Samuel Sturgis, who took command of the district in April. ${ }^{220}$

Sturgis, however, proved equally contentious, albeit for different reasons. Sturgis seems to have thought little of the proposed Indian expedition, and he thought even less of the enlistment of Native American troops. Although Abraham Lincoln ordered the recruitment and armament of 4,000 Indians into Federal service on January 2, Lincoln's directive did not settle the matter, Sturgis believed "it was not the policy of our government to fight high-toned southern gentlemen, with Indians.” Sturgis ordered a halt to Indian enlistment, threatening to arrest officers who continued to recruit Native Americans. Sturgis' draconian rule proved deeply unpopular, and he was excoriated as an outsider by the Kansas press. Sturgis' obstinacy and unpopularity prompted his ouster within a month, and in early May, Brigadier General James Blunt assumed command of the department. ${ }^{221}$

No Federal commander exerted greater influence on Indian Territory throughout the Civil War than James Gilpatrick Blunt. Born in Maine, Blunt exhibited a sense of adventure early in life, taking to the sea on merchant vessels in his youth. Blunt moved to Ohio and attended medical college in the 1840 s but, like James Lane, found himself drawn to Kansas during the tumultuous 1850s. An outspoken abolitionist and ardent Republican, Blunt threw himself into

${ }^{220}$ Henry Halleck to Edwin Stanton, March 28, 1862, Official Records 8, 647-648; Castel, Civil War Kansas, 81-82; “General Orders No. 7," Henry Halleck, Official Records 8, 832; Henry Halleck to Samuel Sturgis, April 6, 1862, Official Records 8, 66; Nichols, Lincoln and the Indians, 38-418. Hunter was replaced by Denver (after which Denver, Colorado is named), who almost immediately was replaced by Sturgis. Denver, however, remained in command of the Indian expedition until Sturgis' removal, when Denver was eventually removed and General Blunt was free to appoint a leader for the expedition.

${ }^{221}$ Henry Halleck to Edwin Stanton, March 28, 1862, Official Records 8, 647-648; Castel, Civil War Kansas, 81-82; "General Orders No. 7," Henry Halleck, Official Records 8, 832; Henry Halleck to Samuel Sturgis, April 6, 1862, Official Records 8, 66; Nichols, Lincoln and the Indians, 38-418; Mark Lea Cantrell and Mac Harris, editors, Kepis and Turkey Calls: An Anthology of the War between the States in Indian Territory (Oklahoma City, OK: Western Heritage Books, 1982), 74. Cantrell and Harris's work is an edited volume of essays that originally appeared in the Chronicles of Oklahoma. Although dated, the volume nevertheless contains useful surveys of select topics regarding the Civil War in Indian Territory. 
Kansas's partisan, paramilitary politics. Blunt made his mark in the first year of the war in fighting along the Kansas-Missouri border as a member of "Lane's Brigade," and Blunt almost certainly owed his promotion to his close relationship with James Lane. Upon learning of Blunt's promotion to brigadier general, the stunned Kansas press raged that the promotion was politically-motivated. Blunt's appointment to department command, however, was eased by the general unpopularity of Sturgis. With Blunt's appointment, the enlistment of Indian soldiers definitively resumed, and the Indian Expedition once again became a priority. ${ }^{222}$

It should come as little surprise that certain officers balked enlisting Native Americans. The United States military possessed a complicated history with Natives. Throughout early American history, Indians posed a constant threat along the United States' frontier, and the United States clashed even with the Five Tribes, notably against Creeks during the Red Stick War (1813-1814) and Seminoles during the Second (1835-1842) and the Third (1855-1858) Seminole Wars. Yet in many of these conflicts, the United States also employed friendly Indians as scouts, guides, and allies, whose knowledge of the land, unconventional warfare, and indigenous foes proved useful. Yet these Native Americans were usually external allies, not incorporated directly into the United States military.

Also tainting the prospect of utilizing Native American soldiers were the recent depredations at the Battle of Pea Ridge. In March 1862, Union and Confederate armies clashed at Pea Ridge in northwest Arkansas in a bloody two-day battle. Despite the fact that Confederate treaties did not require Indians to fight outside of Indian Territory, the First and Second Cherokee Mounted Rifles under Colonels John Drew and Stand Watie crossed the Arkansas line and fought in Confederate ranks during the battle. Their participation proved controversial. In a

\footnotetext{
${ }^{222}$ Robert Collins, General James G. Blunt: Tarnished Glory (Gretna, LA: Pelican, 2005), 45-48; Castel, Civil War Kansas, 83.
} 
grand charge alongside Texans and Missourians on March 7, the Cherokees overran a Federal artillery battery and scattered troopers of the $3^{\text {rd }}$ Iowa Cavalry. Confederate cavalrymen —white and Indian alike — conglomerated around the captured guns, excited by the successful charge and preoccupied with the scene around them. "The Indians," remembered one Southerner, "swarmed around the guns like bees, in great confusion, jabbering and yelling at a furious rate." Excited by battle and without orders, the situation quickly grew out of a hand. ${ }^{223}$

Although the exact details of what happened next are hazy, it is clear that certain Cherokees killed wounded Iowans and scalped eight bodies. After the battle, an adjutant of the Third Iowa Cavalry reported, "I also saw bodies of the same men [the 8 men scalped] which had been wounded in parts not vital by bullets, and also pierced through the heart and neck with knives," evidence that "fully satisfied" the adjutant that his fellow Iowans had been "brutally murdered." Whatever brutality occurred, it ended when Federal artillery arrived on the field and sent the Indians "hurriedly" retreating. ${ }^{224}$

The incident at Pea Ridge sparked a testy exchange between the Union and Confederate army commanders following the battle, which ended in Confederate defeat. General Samuel Curtis, who commanded the Federal army, sent his Confederate counterpart General Earl Van Dorn a terse message conveying his "regrets that we find on the battlefield, contrary to civilized warfare, many of the Federal dead who were tomahawked, scalped, and their bodies shamefully mangled." Curtis expressed his hope the war would not "degenerate to a savage warfare." Van

\footnotetext{
${ }^{223}$ William L. Shea and Earl J. Hess, Pea Ridge: Civil War Campaign in the West (Chapel Hill: University of North Carolina Press, 1992), 101-103.

${ }^{224}$ Shea and Hess, Pea Ridge, 102; John W. Noble to Samuel R. Curtis, April 12, 1862, Official Records. 8, 207; "Report of Brig. Gen. Albert Pike," March 14, 1862, Official Records 8, 288. For a good overall view of the Indian's participation in the campaign, also see Roy A. Clifford, "The Indian Regiments in the Battle of Pea Ridge," Chronicles of Oklahoma, vol. 25, no. 4, 214-322. For a concise general overview of the Pea Ridge campaign, see William L. Shea, War in the West: Pea Ridge and Prairie Grove (Fort Worth: Ryan Place Publishers, 1996); for a detailed campaign study, look to Shea and Hess' Pea Ridge: Civil War Campaign in the West.
} 
Dorn responded by noting that his Indian forces had for many years "been regarded as civilized people" and riposted with a spurious claim that Confederate prisoners had been murdered "in cold blood by their captors, who were alleged to be Germans." 225

The affair at Pea Ridge drew national attention, and undoubtedly cast the use of Native American troops in a negative light. It compounded the commonly-held belief that all Indians were savages, given to barbaric ways of war. Of course, there should have been little surprise that Cherokees engaged in scalp-taking. Various Native American tribes had long taken scalps as symbolic trophies, and the practice had been similarly adopted by white settlers at times. Indeed, Confederate soldiers scalped Opothleyahola's dead and committed other atrocities against civilians in the winter of 1861 . The scalping at Pea Ridge was not the first such incident to occur in the Trans-Mississippi borderland during the war, nor would it be the last. While Samuel Curtis, Samuel Sturgis, Henry Halleck and others balked at the use of Indian soldiers, in the end, both the Union and Confederacy willingly drew from Native American tribes to fill out their ranks, and they would likewise show an equal willingness to engage in "savage warfare" all their own.

Throughout the spring of 1862, the United States recruited and enlisted Native Americans into the First and Second Indian Home Guard (often referred to as the Indian regiments). The Indian refugees of Kansas eagerly enlisted in these regiments for a simple reason: they wanted to return home. More than anything else, the desire to escape Kansas and return to their fields and fireplaces encouraged Indians to enlist; the Indians understood enlistment as a vehicle to liberate

225 T.I. McKinney to Earl Van Dorn, March 9, 1862, Official Records 8, 194; Dabney H. Maury to Samuel R. Curtis, March 14, 1862, Official Records 8, 195. Van Dorn's accusation of German atrocities, probably trumped up, fits well into a larger trend of anti-German nativism throughout the Civil War. Most notably, the heavily German $11^{\text {th }}$ Corps of the Army of the Potomac often served as a scapegoat for Union blunders; see Christian B. Keller, Chancellorsville and the Germans: Nativism, Ethnicity, and Civil War Memory (New York: Fordham University Press, 2007). 
Indian Territory. Federal authorities supported this idea. In an interview with Opothleyahola and other chiefs in late January, Commissioner Dole informed them, "Your enlistment is not done for our advantage only; it will inure to your own benefit." Although the stop-start nature of recruitment "was very discouraging to the Indians - the cause of much dissatisfaction and loss of confidence on their part," the Indians remained adamant in their willingness to take up arms and go home. When General Sturgis briefly halted enlistment in April, the leaders of the various refugee tribes held a "grand council" and agreed to mount "an expedition upon their own responsibility to their homes, in time to put a crop in the spring." Opothleyahola and others wanted to "fight their own way back." Fortunately, recruitment resumed, and the refugees quickly filled out several regiments. ${ }^{226}$

The Union army initially raised two regiments of Indian Home Guard. Their unique title as "Home Guard" hints at their expected usage. General Halleck declared, "These Indians can be used only against Indians or in defense of their own territory and homes." Like the Confederacy, the Federals only expected to utilize the Indian Home Guard in Indian Territory (although like the Confederacy, the Union broke this promise and occasionally used the Indians outside their borders). The First Indian Home Guard consisted of 800 Creeks and 200 Seminoles; essentially, this regiment was filled by Opothleyahola's warriors. Also dotting the First Indian's ranks were several dozen African-Creeks, whose knowledge of English made them critical interpreters between white and Indian officers and soldiers. Unlike the Confederacy, Union Indian regiments were commanded by white officers, although Indians often occupied captaincies and mid-level regimental ranks. Among the captains of the First Indian Home Guard were Creek Indian

${ }^{226}$ George W. Collamore to William P. Dole, April 21, 1862, Annual Report of the Commissioner of Indian Affairs, 155-158; William G. Coffin to William P. Dole, October 15, 1862, Annual Report of the Commissioner of Indian Affairs. 
Tuckabatchee Hacho (Opothleyahola's nephew) and Seminole veterans Halleck Tustenuggee and Billy Bowlegs, both leaders during Opothleyahola's Rebellion. The commander of the First Indian was Colonel Robert Furnas; among Furna's staff was Major Albert Ellithorpe, a Chicago entrepreneur whose journals offer great insight into the regiment's service. The Second Indian Home Guard was a more diverse affair, comprised of Indians from a variety of tribes and would eventually be filled out with Osages and Cherokees. The Second Indian Home Guard was commanded by John Ritchie, another veteran of "Lane's Brigade." 227

By May, the various pieces of the Indian Expedition were coming together. After months of turnover, the military situation seemed to be stabilizing in the hands of General Blunt (and, perhaps, Senator Lane). The First Indian Home Guard was full; recruitment of the Second continued at a brisk pace. Meanwhile, other regiments from Plains and Midwestern states reported for duty at Fort Scott, a "miserable place" in southeast Kansas comprised of several aging army barracks. Among these regiments was the $2^{\text {nd }}$ Ohio Cavalry. Formed in the autumn of 1861 , the $2^{\text {nd }}$ Ohio had seen limited service combatting guerrillas along the Missouri-Kansas line. Among the Ohioan ranks were a number of well-educated young men, many graduates of Oberlin College, who kept meticulous diaries and frequently wrote home. Col. Charles

\footnotetext{
${ }^{227}$ M. Jane Johansson, ed. Albert C. Ellithorpe, The First Indian Home Guards, and the Civil War on the Trans-Mississippi Frontier (Baton Rouge: Louisiana State University Press, 2016), 18; Zellar, African Creeks, 5456; Chris Rein, "The U.S. Army, Indian Agency, and the Path to Assimilation," Kansas History: A Journal of the Central Plains 36 (Spring, 2013), 6-7; Annie Heloise Abel, The American Indian in the Civil War, 1862-1865 (1919; repr., Lincoln: University of Nebraska,1992), 113-116. Gary Zellar's African Creeks traces the long history of African Creek history, but his chapter "African Creeks and the Civil War" illuminates the contributions of African Creeks during Opothleyahola's Rebellion and in Union service. Zellar indicates the First Indian Home Guard constituted seven companies of Creeks, one company of Yuchi Creeks, and two companies of Seminoles at the time of recruitment. Chris Rein's article in Kansas History offers a fine, succinct overview of the regiment's history and challenges facing the tri-racial unit. Rein indicates that over the course of service the regiment grew increasingly varied in composition, with Cherokees, Choctaws and Chickasaws enlisting. Jane Johansson's edits of Albert Ellithorpe's wartime writings (both in his journals and correspondence) offer both a biography of Ellithorpe and something of a regimental history of the First Indian Home Guard. Ellithorpe's writing offers a truly valuable window into the workings of that regiment.
} 
Doubleday, a veteran of William Walker's Nicaraguan filibuster in 1856 , commanded the $2^{\text {nd }}$ Ohio Cavalry. Due to the revolving nature of department commanders that spring, command of the expedition's forces had devolved to Doubleday, the senior-most colonel of those regiments tasked to the expedition. Unlike his predecessors, Doubleday proved anxious to get the expedition underway and proceed southward toward Fort Gibson "with as little delay as possible." Doubleday's ambitious haste soon sparked the first engagement between Union and Confederate forces in Indian Territory. ${ }^{228}$

Also among the expeditionary forces was the $9^{\text {th }}$ Wisconsin Infantry, comprised almost entirely of ethnic German immigrants to the United States. Many of these Germans had prior military experience, either in the Mexican War or in the European revolutions of 1848, and received routine praise for their "excellent discipline," good health, and "soldierly bearing" as one of the best regiments in the department. Hearty and hale, the Germans exhibited their energy and zeal during their brief stay at Fort Scott, during which time they published a regimental newspaper (Der Deutsch Krieger, "The German Warrior”), formed a regimental band, organized "gymnastic exercises" among the men (many of whom were Turners), and grumbled about the high cost of beer (10 cents). The $9^{\text {th }}$ Wisconsin was commanded by Colonel Fredrick Salomon. Hailing originally from Prussia, Frederick was one of four brothers, three of whom served in the Union army. Yet Fredrick perhaps owed his colonelcy to his lone brother not in the armyGovernor Edward Salomon of Wisconsin. Despite his inexperience, Salomon proved a competent officer, well-liked by his men. When rumors circulated that Salomon would receive his brigadier's stars in February, Salomon reportedly declared that "he would not be a general

228 "A Trip to Fort Scott, Kansas," Quiner Scrapbooks, vol. 8, 57, Wisconsin Historical Society, Madison, WI (hereinafter referred to as WHC); Charles W. Doubleday, Reminiscences of the Filibuster War in Nicaragua (New York: G.P. Putnam's Sons, 1886); Charles Doubleday to Thomas Moonlight, May 25, 1862, Official Records $13,397$. 
without the $9^{\text {th }}$ Wisconsin, as he could travel a long ways and not find another such regiment." Episodes like this endeared Salomon to his men, and while he may have owed his position to his brother, he was a capable, caring commander who would play a large role in the days ahead. ${ }^{229}$

True to his word, Colonel Doubleday quickly set men into motion. On the first day of June, Federal regiments left behind eastern Kansas and began marching south. The force consisted of the $2^{\text {nd }}$ Ohio Cavalry, $9^{\text {th }}$ Wisconsin Infantry, elements of the $6^{\text {th }}$ Kansas Cavalry and $10^{\text {th }}$ Kansas Cavalry, and Captain Rabb's $2^{\text {nd }}$ Indiana Battery. Notably absent were the First and Second Indian Home Guard, which despite nearing completion, remained in the vicinity of Humboldt and Iola, near their refugee camps. ${ }^{230}$

As they marched through sparsely settled southeastern Kansas and neared Indian Territory, white Union soldiers experienced their first interactions with Native Americans. Some thirty-five miles north of Indian Territory, the blue-clad column approached a Catholic mission among the Osage Indians, "a collection of some half-dozen large and well-built structures." The Osage proved curious to the newcomers, and "redskins came from different directions to see the unusual sight." "[V]ery much gratified" by the presence of Union soldiers, the natives were especially "tickled" by the expedition's artillery, dubbed "great shining pipes" and "shoot wagons." Hoping to "astonish" the Indian onlookers, Captain Rabb ordered his Indiana battery to put on a demonstration, and the six guns unleashed a round of shells on a nearby hill. "At the roar of the Cannon," Private Jacob Haas of $9^{\text {th }}$ Wisconsin recorded, "many [Indians] ran away

229 "From Fort Scott," "A Trip to Fort Scott, Kansas," "From the Ninth Regiment," and "Letter from the Ninth Regiment," Quiner Scrapbooks, vol. 4, 153-154 and vol. 8, 56-57, WHS. One Ohio trooper thought the $9^{\text {th }}$ Wisconsin "the best infantry regiment in the department." The Tenth Kansas Infantry worked to "out-drill the Wisconsin Ninth," a tacit admission the Ninth set the standard in discipline and drill. In general, the Ninth seemed to garner praised and admiration from every quarter. "From the Second Cavalry," Western Reserve Chronicle [Warren, OH], July 9, 1862; Lawrence Republican, May 19, 1862.

${ }^{230}$ Henry Whipple Chester, Recollections of the War of the Rebellion, eds. Alberta R. Adamson, Robert I. Girardi, and Roger E. Bohn (Wheaton, IL: Wheaton History Center, 1996), 31. 
and others closed their eyes and ears. Others laid hands over their mouths (Indian sign of fear)."

Other Indians rushed over the luckless hill at the firing's conclusion and unsuccessfully attempted to find shell fragments. While the Indians observed the artillery demonstration, the Federals observed the Indians. The mission grounds were "swarming with fat-cheeked, blackeyed, black-haired Indian children," some of whom were likewise naked but others "dressed in a civilized manner" for school." One Wisconsin correspondent thought that with a few decades more of instruction, the educated Osages' "effect on the country in the vicinity must be plainly manifest."231

After several days of marching, the Union regiments halted along the Spring River, a "stream of surpassing beauty, clear, cool, and refreshing." The camp made for a "beautiful situation," surrounded by a low ring of hills that afforded "an extensive view of the country" and protection from enemies. Wheat and peach trees graced the countryside, and in the tall grass rattlesnakes hid. All seemed taken with the area's beauty. The soldiers sculpted small clay ovens and baked bread and biscuits. Yet ominously, Henry Chester noted, "We were now near the supposed location of the enemy, and heard rumors of being attacked before the night." From their camp on Spring River, the expeditionary force was less than two miles from the Indian Territory line. ${ }^{232}$

${ }^{231}$ Quiner Scrapbooks, "From the Ninth Wisconsin Infantry," vol. 8, 56, WHS; Lawrence Republican, "The Indian Expedition," May 29, 1862 and "Indian Expedition," June 19, 1862; Jacob Haas, This Day We Marched Again: A Union Soldier's Account of War in Arkansas and the Trans-Mississippi, The Civil War Diary of Jacob Haas, ed. Mark K. Christ (Little Rock, AR: Butler Center for Arkansas Studies,), 26-28. A number of Osages from the mission and its vicinity eventually enlisted in the $2^{\text {nd }}$ Indian Home Guard. William Weer to Thomas Moonlight, June 13, 1862, Official Records vol. 13, 430-431.

${ }^{232}$ Whipple, Recollections, 32; Haas, This Day We Marched Again, 27-28; Quiner Scrapbooks, "From the Ninth Wisconsin Infantry," June 10, 1862, "Letter from Kansas," June 22, 1862, and "A Trip to Fort Scott, Kansas," July 1, 1862, vol. 8, WHS; Michael Zimmer, Michael Zimmer's Diary: Deutsches Tagebuch aus dem Amerikanischen Bürgerkrieg, eds. Jürgen Macha and Andrea Wolf (Frankfurt, Peter Lang GmbH, 2001), 127-128. 
As the small column enjoyed the beauty and bounty of their Spring River encampment, on June $4^{\text {th }}$ word arrived from department headquarters at Fort Leavenworth that Colonel Doubleday had been removed from command of the expedition and was to be replaced by Colonel William Weer of the $10^{\text {th }}$ Kansas Infantry. The Ohio colonel was further ordered to cease his advance. Doubleday admitted, "the news rather surprised him," and word of the change caused a stir around the camp. "All seem astonished," wrote one stunned Ohio trooper. Outraged at his inexplicable removal, Doubleday resolved to resign "rather than submit to the persistent efforts of these men to forward their own selfish ends." 233

It's unclear what exactly prompted Doubleday's ouster and Weer's promotion. The order came from General James Blunt, who had assumed command less than a month before. Perhaps Blunt was simply exercising his discretion as department commander in appointing the man of his choice to lead the expedition. Yet a more likely explanation lies, once again, with the influence of Senator James Lane. William Weer was a veteran of antebellum Kansas politics. "Mingling in the political broils and bleeding shrieks of Kansas," one observer wrote, "he soon rose high in the political circle, always being found where money was most plenty." Like his superior offices James Blunt, Weer was likewise a member of James Lane's political circle, having also served in "Lane's Brigade" earlier in the war. In short, behind Blunt' s appointment of William Weer may well have been the hand of James Lane, working again to ensure his Kansan supporters were in posts of importance. Certainly the Ohioans, whose leader had been ousted from command, suspected Kansan political machinations were afoot. Captain Alvred Nettelton of the $2^{\text {nd }}$ Ohio thought Doubleday's “supercession is little less than an insult...this

${ }^{233}$ Lawrence Republican, "The Indian Expedition,” June 5, 1862; William Weer to Charles Doubleday, June 6, 1862, Official Records 13, pgs. 418-419; Luman Harris Tenney, War Diary of Luman Harris Tenney (Cleveland, OH: Evangelical Publishing House, 1914), 16-17; Cleveland Morning Leader, "From the Second Cavalry," June 13, 1862. 
change of command is only another manifesto from the politico-military cabal at Leavenworth."

Doubleday agreed, "despairing of ever being permitted to share in the glories of our arms while confined under Kansas political domination." Regardless of why yet another change in command of the expedition occurred, the promotion of Colonel William Weer to the expedition's head would have disastrously profound implications for the Indian Expedition, Indian Territory, and Indian refugees in the weeks ahead. ${ }^{234}$

Despite his removal from the head of the Indian Expedition and pending resignation, Doubleday nevertheless faced the prospect of immediate action. The Ohio colonel had learned that a small body of Confederates, reportedly numbering 1,500 men, were encamped amidst Cowskin Prairie some thirty-five miles south in Cherokee Nation. The Confederates were under the command of Stand Watie and included a mixed force of Watie's Cherokees and several hundred Missourians under Col. John Coffee. Further, several thousand Confederates under Missouri General James Rains were reportedly gathering at Fort Smith, perhaps in preparation for reinforcing Watie's command. Determined to strike quickly while the opportunity lasted,

\footnotetext{
234“"Our Military Correspondence. From the Second Ohio Cavalry," Jeffersonian Democrat [Chardon, OH], August 1, 1862; "Resignation of Col. Doubleday," and "From the Second Cavalry," Cleveland Morning Leader, June 23, 1862. Doubleday's removal sparked further debate among the Cleveland newspapers as to why Doubleday was removed. It was reported in several newspapers (including the Cleveland Morning Leader and the Leavenworth Conservative) that in February of 1862, Doubleday had ordered his regiment to return "fugitive [slaves] to disloyal masters" in Missouri. The $2^{\text {nd }}$ Ohio contained a fair number of anti-slavery and abolitionist men, and the order provoked "indignation" among some of the regiment's officers. This interpretation was rejected by a correspondent of the $2^{\text {nd }}$ Ohio in the Ashtabula Weekly Telegraph, who claimed Doubleday gave no aid to the white man in capturing several runaway slaves; further, the correspondent noted, "I think that no one will deny that Col. D. is very popular with his regiment." Upon Doubleday's removal in June, the Cleveland Plain Dealer questioned whether abolitionist "persecution" from within the regiment caused Doubleday to resign. The Cleveland Morning Leader disagreed, thinking it "all a Plain Dealer trick, to make capital against the Abolitionists." February scandal aside, Doubleday seems to have been well-liked by his men, and it doesn't seem likely that Doubleday was removed due to internal dissatisfaction among his regiment or from abolitionist pressure back home. "The Charges Against Col. Doubleday," Cleveland Morning Leader, February 2, 1862; "For the Telegraph," Ashtabula Weekly Telegraph, April 12, 1862; "Col. Chas. Doubleday," Cleveland Morning Leader, June 25, 1862.
} 
Doubleday disregarded Weer's order, dashed off a message to Weer informing him of the situation, and marched advanced on Cowskin Prairie on June $6{ }^{235}$

Instead of advancing with his entire command, Col. Doubleday wisely elected to proceed with a small force of artillery, cavalry, and infantry. The mixed force was comprised of two battalions of the $2^{\text {nd }}$ Ohio Cavalry, two companies of the $6^{\text {th }}$ Kansas Cavalry, four companies of the $9^{\text {th }}$ Wisconsin Infantry, two companies of the $10^{\text {th }}$ Kansas Infantry, and Rabb's Indiana battery — all told, roughly 1,000 men. For marching men, thirty-five miles was well over a single day's march; recognizing the need for speed, Doubleday arranged for over a dozen wagons to carry the infantry south. The Ohioan had effectively turned his selected force into a mobile command. ${ }^{236}$

After a long day's ride of over thirty miles and two river crossings, the Union force crested a ridge late that evening and was met with an exhilarating scene. The road led down into the "lovely valley of Grand River." Across “a velvet green prairie some four miles wide," the Grand River meandered along, its bank lined with "dense timber." The trail continued down into the valley, disappearing into the trees to a ford across the river. Several miles off to the right, on the near side of the river, could be seen "dense smoke, supposed to proceed from the enemy's camp." Mounted men could also be seen in the distance driving large herds of cattle. From the rise, twenty-two year old Jacob Haas of the $9^{\text {th }}$ Wisconsin admitted, "Quickly our guns were in hands and we made sure that the same were loaded."237

\footnotetext{
235 "Report of Col. Charles Doubleday," June 8, 1862, Official Records 13, 102; William Weer to Thomas Moonlight, June 7, 1862, Official Records 13, 422; Tenney, War Diary, 17.

236 "Report of Charles Doubleday," June 8, 1862, Official Records 13, 102; "From the Second Cavalry," Cleveland Morning Leader, June 23, 1862; "The Indian Expedition," Cleveland Morning Leader, June 21, 1862; "From the Second Cavalry," Western Reserve Chronicle, July 9, 1862. In his diary, Michael Zimmer of the $9^{\text {th }}$ Wisconsin (who didn't accompany the expedition to Cowskin Prairie) recorded that Companies A,B,C, and H went along; "each company got four wagons so everyone could ride." Zimmer, Michael Zimmer's Diary, 128.

237 "From the Second Cavalry," Western Reserve Chronicle, July 9, 1862; Haas, This Day We Marched Again, 28-29.
} 
Despite the late hour and "now declining sun," Doubleday ordered the two battalions of Ohio cavalry forward to "reconnoitre and find the exact location" of the enemy's camp. A battalion of Ohioans under Major Burnett advanced toward the right, in the direction of the smoke. The other Ohio battalion under Major Miner advanced straight ahead toward the treelined banks of the Grand River and the ford, in hopes of cutting the Rebels off. Major Burnett's troops "beat the woods for two hours," only to discover "the fire was made by an old nigger on purpose to mislead us." Major Miner's troopers, however, encountered enemy pickets of Stand Watie's Cherokee command along the river. A brief exchange of shots occurred, and at least one Confederate was captured, who revealed that Watie's main camp was several miles still ahead. 238

While the cavalrymen scouted the brush, the infantry and artillery made their way down the valley toward the ford. Learning that Watie's camp was still ahead across the river, Doubleday ordered the Kansans to deploy as skirmishers and cross the river. Fearing that the "the gloomy woods" were "full of 'em," the Kansans refused to advance. "So mad, that the tears fairly stood in his eyes," Doubleday "asked if there was any two would volunteer to dismount and cross the river to see if there was any enemy there." A number of Ohioans volunteered, riding down the dark, "narrow" path toward the river. The impetuous Germans of the $9^{\text {th }}$ Wisconsin abandoned their wagons and followed suit. The Ohio cavalry and Wisconsin skirmishers splashed across the river, the infantry wet to their waists. Jacob Haas recalled the

\footnotetext{
238 "From the Second Ohio Cavalry," Western Reserve Chronicle, July 2, 1862; "From the Second Cavalry," Western Reserve Chronicle, July 9, 1862; "Report of Col. Charles Doubleday," June 8, 1862, Official Records 13, 102; Tenney, War Diary, 19. Another Ohio correspondent recorded that the "smoke proceeded from a line-kiln and burning brush."
} 
"river bottom was sandy and our wagons had great difficulty crossing." By 9 p.m. the Federal force had forded the Grand River and "pushed forward close to the camp of the enemy."239

Darkness hindered Doubleday's ability to “accurately ascertain their [Confederates'] precise position," but he could see the camp of Stand Watie on a small grove ahead. Doubleday ordered Rabb's Indiana battery to the front, the cavalry scampering out of the roadway as the "guns and caissons went thundering past as fast as 12 good horses could take 'em." Moving out into open prairie, the Indiana guns took position on a small hill 500 yards from the enemy and "threw a few shot and shell into their camp." "The first shell burst right in the center of their ranks," recalled one observer gleefully, "killing two outright and wounding several more." Sergeant Luman Tenney of the $2^{\text {nd }}$ Ohio looked on in excitement, too. "The shelling was splendid," Tenney enthused in his diary. "The shells would bound from tree to tree and burst with a thundering noise." When the shelling ceased, the infantry and cavalry advanced out of the woods toward the enemy's encampment, only to find it empty. As Captain Nettleton of the $2^{\text {nd }}$ Ohio explained in a letter home, "The Cherokees cannot stand before what they call our 'shooting wagons."” Perhaps recalling the recent Kansan intrigue against his own colonel, Nettleton continued, "The scream of a shell is nearly as terrible to the ears of a red man as Gabriel's bugle call will be to Kansas politicians." ${ }^{240}$

Caught unaware by the Federals' rapid southward movement and the sudden shelling of their camp, the Confederates fled "with no great amount of ceremony," and the "with no show of resistance the motley crowd broke precipitately for the hills of Arkansas." In the darkness, the

\footnotetext{
239 "From the Second Ohio Cavalry," Western Reserve Chronicle, July 2, 1862; "From the Second Cavalry," Western Reserve Chronicle, July 9, 1862; Hass, This Day We Marched, 28-29.

240 "From the Second Ohio Cavalry," Western Reserve Chronicle, July 2, 1862; "From the Second Cavalry," Western Reserve Chronicle, July 9, 1862; Haas, This Day We Marched Again,28-29; Official Records, "Report of Col. Charles Doubleday," June 8, 1862, vol. 13, 102; Tenney, War Diary, 17; "From the Second Cavalry," Cleveland Morning Leader, June 23, 1862; "From the Second Cavalry," Cleveland Morning Leader; June 26, 1862.
} 
Rebels' "superior knowledge of the country," allowed them to escape the clutches of the $2^{\text {nd }}$ Ohio in their rear. Tired from the long day, the soldiers slept on their arms that evening. The next morning, the Federals took position in the Rebel's abandoned camp, and although scouts reported that the enemy had reorganized some fifteen miles south, Doubleday elected to heed Weer's orders and not pursue any further. ${ }^{241}$

Evidence of the Confederate's panicked withdrawal littered their abandoned encampment. "Their tents, swords, guns and pans with meat half fried all lay scattered on the ground," reported Jacob Haas. The Federals spent much of June 7 following the Confederates' trail. The Rebels "scattered in bands of 50 or 60 ," making them difficult to track. Although an Ohio scouting party briefly skirmished with a small party of Rebels, most of the day was spent rounding up the hundreds of horses and mules and over one thousand head of cattle abandoned by the Confederates. Although the Rebels apparently suffered no killed or wounded, they did lose several dozen men, "white, black, and red" as prisoners, a likely indication that black slaves had accompanied the Confederates in the field. ${ }^{242}$

On the morning of June $8^{\text {th }}$, the victorious little command began its return trip back to the camp on Spring River. Cavalry troopers played cowboy, herding droves of cattle and horses. Several officers of the $2^{\text {nd }}$ Ohio appropriated an abandoned rebel wagon and "had a gay time" on the ride back. Yet darker reports of plunder and fraud marred the expedition's return. In a July newspaper expose, one correspondent charged Colonel Doubleday of fraud. Under Doubleday's orders, Captain Greeno of the $6^{\text {th }}$ Kansas Cavalry requisitioned some 75 head of cattle from a

241 "From the Second Ohio Cavalry," Western Reserve Chronicle, July 2, 1862; "From the Second Cavalry," Western Reserve Chronicle, July 9, 1862; Haas, This Day We Marched Again, 28-29; Official Records, "Report of Col. Charles Doubleday," June 8, 1862, vol. 13, 102; Tenney, War Diary, 17; "From the Second Cavalry," Cleveland Morning Leader, June 23, 1862; "From the Second Cavalry," Cleveland Morning Leader; June 26, 1862.

${ }^{242}$ Haas, This Day We Marched Again, 28-29; "From the Second Cavalry," Western Reserve Chronicle, July 9, 1862; “Report of Col. Charles Doubleday," June 8, 1862, Official Records 13, 102. 
"loyal woman" living along the Neosho River, who had escaped enemy depredations "on account of her sex and widowhood." The woman acquiesced to the deal on the promise that she would be paid in several days' time. Yet when the woman visited Colonel Doubleday at Camp Spring River, she was told "that he could do nothing about it. Congress had made an appropriation for such cases.” The widow received no payment for the cattle taken. ${ }^{243}$

Likewise, reports circulated that the Federals had taken horses from the various smaller tribes of northeastern Indian Territory—Seneca, Quapaw, and Shawnee—without payment. Other goods were confiscated from passerby, including the horse and saddle of an "Indian woman... in defiance of her humble plea not to take them." The Kansan correspondent reported only several hundred horses and cattle "were taken from the enemy, and the rest from Union men, women and loyal Indians.” The result was approximately $\$ 29,000$ in property claims left to the Federal government, while the captured livestock were "hurried north" and "turned over to the beef contractor" at Fort Scott. Maybe, the correspondent charged, Colonel Doubleday's "retirement from the service, was not so much 'Kanas political domination' as was owing to the profits of the expedition actually received." Although diaries and letters reveal little about the possibility of fraud, Sergeant Luman Tenney admitted to his diary on June 8th: "Jayhawked the people badly." Having skedaddled the enemy at Cowskin Prairie and plundered the countryside, the small expedition as back in Camp Spring River by the evening of June $8^{\text {th }} \cdot{ }^{244}$

A relatively minor affair, the Battle of Cowskin Prairie nevertheless foreshadowed the larger expedition to come in several ways. First, Confederate aversion to battle hinted at the 1862.

${ }^{243}$ Tenney, War Diary, 18; Lawrence Republican, “Cows, Calves, Contractors and Contracts," July 2 ,

${ }^{244}$ Tenney, War Diary, 18; Lawrence Republican, “Cows, Calves, Contractors and Contracts," July 2 , 1862. Interestingly, the reports of the number of cattle taken vary widely. The figure commonly cited in the wake of the Cowskin Prairie expedition was 1,500 cattle; yet on June $8^{\text {th }}$, immediately following his return to camp, Colonel Doubleday only reported 500 to 600 cattle taken. "Report of Col. Charles Doubleday," June 8, 1862, Official Records 13, 102. 
growing disorganization of their command structure and their inability to challenge a wellorganized advancing foe. Second, the plundering and possible fraud committed by Federal soldier against the denizens of Indian Territory marked only the beginning of years of rapacious confiscations, marauding, and banditry by Union, Confederate, and criminal forces. Third, and finally, the reappearance of Federal authorities in Indian Territory hastened the collapse of Confederate-Cherokee relations. On the evening of June $8^{\text {th }}$, as Doubleday's expeditionary forces tramped into Camp Spring River across the Kansas line, to their "great surprise we saw a large number of wild Indians with their small ponies and tents pitched close to ours." Osages with faces "painted yellow, blue, black and green" and "more civilized Cherokees" dotted the Federal camp. In the coming days, more Indians "came who had been driven away by Indian rebels and asked for help." Colonel Doubleday's June $6^{\text {th }}$ expedition into Indian Territory marked the first time Federal soldiers had entered Indian Territory since May of 1861. Within just a few days after the brief reappearance of Federal authority, Indians from the Territory were hastening to Camp Spring River to seek sanctuary. When the expedition returned to Indian Territory a few weeks later five times larger in size, Confederate Indians would defect in droves. ${ }^{245}$

The skirmish at Cowskin Prairie was all that came of Colonel Doubleday's brief tenure as the Indian Expedition's commander. Refusing to subordinate himself to another colonel, Doubleday departed for Washington, D.C. in a futile attempt to regain command. Instead, the First Indian Expedition would be led by Colonel William Weer. A competent, "efficient officer" when sober, Weer was known to be "addicted to the liquor habit," an unfortunate flaw that would

${ }^{245}$ Haas, This Day We Marched Again, 29-30; Zimmer, Michael Zimmer's Diary, 129. 
make its mark in the days ahead. Yet with Doubleday gone, Weer gamely set about reorganizing and strengthening the expedition for its formal push south into Indian Territory. ${ }^{246}$

William Weer's ascent to command of the Indian Expedition was symptomatic of the complex political arena from which the venture was born. For President Lincoln, the Indian Expedition was a means of reasserting military control over Indian Territory and repairing broken relations with the Five Tribes. For James Lane, David Hunter, and others, however, the expedition promised a chance at battlefield victory and its attendant glory. For Native American refugees and their Indian agents, they forced the military to acknowledge their needs and transform the expedition into a liberation of their homelands preceding a triumphant, perhaps vengeful, return home. The likewise convinced the United States military to clothe, arm, and train them as Indian Home Guard regiments.

Despite a tumultuous spring that witnesses a parade of incoming and outgoing expedition commanders, the expeditionary forces enjoyed a minor success at Cowskin Prairie, and by summer the Indian Expedition was ready to march. Yet Kansan politicking — so instrumental to the venture's existence in the first place - also left the entire expedition in the hands of a questionable commander whose penchant for drink would spell ruin for the expedition in the blisteringly hot, dry days ahead.

${ }^{246}$ Cleveland Morning Leader, "From the Second Cavalry," June 23, 1862; Wiley Britton, The Union Indian Brigade: The Five Civilized Indian Nations in the Civil War (Kansas City, MO: Franklin Hudson Publishing, 1922), 62-63. Wiley Britton was a member of the $6^{\text {th }}$ Kansas Cavalry and spent much of the war serving alongside the Indian Home Guard regiments. His history of their brigade is thus somewhat autobiographical. 


\section{"Sweating, Choking, Broiling":}

\section{Environment, Leadership, and the Failure of the First Indian Expedition}

"I have stood with arms folded and seen my men faint and fall away from me like the leaves of autumn because I thought myself powerless to save them. " -Col. Frederick Salomon, $9^{\text {th }}$ Wisconsin Infantry, July 18,1862

Sergeant Michael Zimmer quietly awoke in the middle of the night, having gone to sleep just a few hours before. The thirty-eight year old carpenter, a veteran of the Mexican War, was offered little explanation as to why, in the dead of night, he and his comrades of the $9^{\text {th }}$ Wisconsin being ordered "to fall in with rifle and leather, the rifles loaded with live ammunition." The men were anxious and confused; "we had to fall into battle order and expected the attack at any moment." Nor were Zimmer and the Wisconsin soldiers alone in rousing. Despite the approaching midnight hour on a hot summer night, soldiers throughout the Indian Expedition's camp grimly socketed bayonets and shouldered arms in the darkness. Indiana artillery crews loaded their guns with grapeshot and canister, and Ohio cavalrymen grabbed carbines and mounted their horses. The camp stirred into motion at the prospect of violence. ${ }^{247}$

The threat, however, did not come from without, but from within. A mutiny was underway. Colonel Frederick Salomon, commander of Zimmer's $9^{\text {th }}$ Wisconsin and second-incommand of the expedition, determined expedition commander Colonel William Weer "was either insane, premeditated treachery to his troops, or perhaps that his grossly intemperate habits long continued had produced idiocy or monomania." Meeting with other regimental commanders in the expedition, "they all met by common consent, as it were, to look the matter in the face. Starvation was imminent, and the man who should look after the command was habitually

${ }^{247}$ Zimmer, Michael Zimmer's Diary, 136; "Interesting Letter from the Ninth Wisconsin Regiment," Quiner Scrapbooks, Vol. 8, 58-59, WHS. 
drunk." The commanders agreed that Weer must be deposed, and Frederick Salomon ordered Company C of his own Ninth Wisconsin Infantry to arrest Colonel Weer. ${ }^{248}$

Around 11 o'clock that night, Captain Eckhart led his stalwart Germans to William Weer's tent to demand the colonel's surrender. Having already retired for the evening, Weer was taken aback by the sudden arrival of an armed guard. Weer "showed a decided unwillingness to go along, and attempted to open a lengthy debate with the captain.” Brooking no discussion, Eckhardt again asked for Weer's removal, which Weer refused. 'You are my prisoner," Captain Eckhardt barked in broken English, and he ordered his company to "charge bayonets!" One observer recalled that "the rifles came down with a click and a rattle, and as they closed in on him [Weer], he saw they would obey any order the Captain gave them, and so he surrendered at discretion." In his nightshirt and bare feet, Weer was escorted to Colonel Salomon's tent. Upon entering Weer took stock of the men present; almost all of expedition's commanders were present. When Weer's eyes found battery commander and fellow Kansan Captain Norman Allen, the stunned colonel cried out "'And you are here?' and burst into tears." Weer was promptly arrested, and Colonel Salomon took command. ${ }^{249}$

Mutiny successful, the First Indian Expedition abruptly reversed course. Colonel Frederick Salomon immediately ordered the expedition to withdraw, and around 3 a.m. on July 19, 1862, blue-clad columns marched northward. Only the Indian Home Guard regiments were left behind. Once again, Union forces seemed to be abandoning Indian Territory to its fate. ${ }^{250}$

248 "From the Second Cavalry," Cleveland Morning Leader, August 5, 1862.

249 "Interesting Letter from the Ninth Wisconsin Regiment," Quiner Scrapbooks, Vol. 8, 58-59; Isaac Gause, Four Years with Five Armies: Army of the Frontier, Army of the Potomac, Army of the Missouri, Army of the Ohio, Army of the Shenandoah (New York: Neale Publishing, 1908), 94-95; Tenney, War Diary, 21-22.

${ }^{250}$ Zimmer, Michael Zimmer's Diary, 136; Frederick Salomon, “General Orders No. 1,” July 18, 1862, Official Records 13, 476-477. 
Why did the long-awaited Indian Expedition, which opened so promisingly in the first weeks of July, culminate in mutiny? Both nature and man played a role in the expedition's failure. In recent years, Civil War scholars have begun to seriously examine the relationship between the environment of the 1860s and the armies who marched and fought through it. The environment possesses agency; it is not just a static landscape, but rather an active participant in shaping military affairs. The failure of 1862 Indian Expedition exemplifies the environment's capacity - in this instance, through local weather - to dramatically alter military events. An extraordinarily, historically hot summer, accompanied by water shortages and a dearth of forage, sapped the energy, health, and morale of Union soldiers and their mounts. ${ }^{251}$

Faced with a hostile environment which imposed serious logistical, strategic, and morale issues, the Expedition needed stout leadership and careful planning to overcome these obstacles. Instead, the Expedition was saddled with William Weer, whose inebriation and incompetence prevented Union forces from adequately addressing environmental issues. The result was an increasingly sick, anxious, and angry force—officer and enlisted alike. When Frederick Salomon and the expedition's officers arrested Weer on the night of July 18, "the whole command was in ecstacies [sic] over the deposing of the old vagabond."252

${ }^{251}$ A spate of recent scholarship seeks to connect environmental and military history. Battling the Elements: Weather and Terrain in the Conduct of War, edited by Harold A. Withers, et. al. (Baltimore: Johns Hopkins University Press, 1998), offers a wide array of case studies on the impact of the environment in battle, including as essay on Union General Ambrose Burnside's disastrous "Mud March" in January 1863. Natural Enemy, Natural Ally: Toward an Environmental History of War, edited by Richard P. Tucker and Edmund Russell (Corvallis: Oregon State University Press, 2004) provides a similar case study approach on the relationship between war and the environment more broadly, including an essay by Mark Fiege that views the war as a "a struggle not simply between economies - between the stereotyped North and agrarian South, for example — but between ecologies," and uses Gettysburg to demonstrate the North's ability to produce the food, forage, and supplies (the "military ecology") vital to the Army of the Potomac's success. The Blue, the Gray, and the Green: Toward an Environmental History of the Civil War, edited by Brian Allen Drake (Athens: University of Georgia Press, 2015) contains two essays especially useful for this chapter: Kenneth Noe's "Fateful Lighting: The Significance of Weather and Climate to Civil War History," and Megan Kate Nelson's “"The Difficulties and Seductions of the Desert': Landscapes of War in 1861 New Mexico."

252 "From the Second Cavalry," Cleveland Morning Leader, August 5, 1862. 
Yet the Expedition and its eventual failure produced profound impacts on military and civil affairs within Indian Territory. For the thousands of destitute Indian refugees in Kansas, the expedition's failure prevented their return home. Yet another long Kansan winter awaited them. The appearance of the Union army that summer caused thousands of Cherokees, including many Confederate Cherokees and Chief John Ross, to defect to the Union cause. But the Federal army's subsequent retreat left defectors vulnerable and Native Americans even more wary of Union promises of assistance. Meant to secure Indian Territory for the Union and allow refugees to return home, the First Indian Expedition only deepened the suffering of Native Americans while failing to oust the Confederate army's hold over the Territory.

In the warmth of late spring, however, such dark portents lay far in the future. Instead, throughout June soldiers of the Indian Expedition busied themselves with the mundane details necessary for any serious military campaign. Soldiers marched and drilled, commanders requisitioned supplies, and everyone looked forward to finally taking the field. Unlike his predecessor Charles Doubleday, William Weer initially proved more cautious in his preparations for invading Indian Territory. Weer determined to advance only when ready and spent much of June tending to the necessary, sundry affairs of conducting a proper expedition into enemy territory. ${ }^{253}$

While making proper logistical preparations, Colonel Weer also grappled with "the one thousand and one difficulties I have to encounter with the Indians." Weer was uneasy about the

${ }^{253}$ William Weer to Thomas Moonlight, June 6, 1862, Official Records 13, pgs. 419-420; William Weer to Thomas Moonlight, June 7, 1862, Official Records 13, 422; William Weer to Thomas Moonlight, June 21, 1862, Official Records 13, 441-442. Weer was especially concerned about the muddled state of logistics within the department. Instead of one centralized supply depot, materials were being sent to both Fort Scott and Humboldt, Kansas, confusing efforts to outfit the expedition. Weer urged that "one or the other be selected and everything concentrated at one point," a plea that fell on deaf ears. 
possibility of violence as Union soldiers marched south; in particular, he worried the Indian Home Guard would seek revenge upon their secessionist brethren. "The evident intention," the Kansas colonel warned, "is to Jayhawk." Eventually, several Indian agents were tasked with accompanying the expedition south. Not all Indian news caused headaches, however. Reports reached Weer in Kansas that "large bodies of Union Indians exist among all these people clear to Fort Cobb, and they await our advance in order to take the field in behalf of the Government." With the help of refugee Indians, Weer sent runners south "all through Indian country, notifying those in secret that help is nigh." ${ }^{254}$

Moreover, William Weer also understood the importance of advancing into Indian Territory only when accompanied by the Indian Home Guard regiments, "as this expedition is especially intended to aid them to recover possession of their homes and to bring back the Indian country under subjection of the Government." Weer wrangled with the Indian regiments and the refugee community to get the Home Guard ready for action. The most difficult issue stemmed from the Home Guards' proximity to the refugee camps near Leroy. Enlisted Native Americans looked not to their officers-Indian or white—for orders, but rather "run to the chiefs for advice, and are controlled by them as against the captains." Weer reassured the Indian officers of their authority, which "highly pleased" them, and moved the regiments away from the refugee camps "to get them away from the influence of the chiefs." Even with officer authority reasserted, the Indian regiments, especially the still-forming Second Indian Home Guard, were woefully lacking in supplies. Weer also reported shortages in medicine and doctors, giving rise to illness among

\footnotetext{
${ }^{254}$ William Weer to Thomas Moonlight, June 13, 1862 and June 22, 1862, Official Records, vol. 13, 430$431,443-444$.
} 
Native American soldiers, who "seem incapable of endurance." Supplies, doctors, and mustering officers were requested. ${ }^{255}$

Whatever difficulties the Indian soldiers posed, however, they left quite an impression among all observers. Once the officers exerted control, Weer admitted the Indians "are very docile, seeming anxious to learn and full of fight, as they are getting the war-whoop all the way along." After encountering a company of Seminoles from the $1^{\text {st }}$ Indian Home Guard, Corporal Robert McMahan thought them "beautifully formed" and was surprised by their well-uniformed dress. Major Albert Ellithorpe, an energetic and ambitious thirty-seven year old Chicagoan and staff officer in the $2^{\text {nd }}$ Indian Home Guard, extoled the martial virtues of his soldiers. "I think I have fully settled the fact of Indian capability \& sussiptibility [sic] to arrive at a good state of military discipline," Ellithorpe declared, comparing their drill "equal to any white soldier." Ellithorpe enthused, "They will make brave \& ambitious sholdiers [sic] I have no doubt. Our country may well fell proud that these red men have last fell into the ranks to fight for our flag, \& aid in crushing treason." ${ }^{256}$

Other Federal soldiers found the Native Americans' martial abilities less inspiring, more amusing. Upon "the pleasure of seeing the Indians drill," Sergeant Zimmer confessed to his diary, "It was too funny to describe everything." The Fort Scott Bulletin described a dress parade among the Indians, noting the "ceremonies progressed very well until the command 'Parade Rest' was given, when, with a unanimous grunt of satisfaction, the Indians seated themselves

${ }^{255}$ William Weer to Charles Doubleday, June 6, 1862, and William Weer to Thomas Moonlight, June 13, 1862, June 16, 1862, June 21, 1862, and June 23, 1862, Official Records, vol. 13, 418-419, 430-431, 434, 441-442, 445.

${ }^{256}$ William Weer to Thomas Moonlight, June 16, 1862, Official Records 13, 434; McMahon, Robert T., Reluctant Cannoneer: The Diary of Robert T. McMahan of the Twenty-Fifth Independent Ohio Light Artillery, edited by Michael Banasik (Iowa City, IA: Camp Pope Publishing, 2000), 38; Johansson, ed., Albert C. Ellithorpe, 19-20. As a trooper in the $2^{\text {nd }}$ Ohio Cavalry, Robert McMahan's diary offers good sundry details of the expedition. McMahan later transferred (along with other members of the $2^{\text {nd }}$ ) into the $25^{\text {th }}$ Ohio Light Artillery. 
comfortably on the ground." "They understood the "rest' perfectly," joked the Bulletin, "but the 'parade' evidently has no place in their tactics." The Bulletin predicted the Indian soldiers "will be as valuable as a flock of sheep in time of action. They ought to be disbanded immediately."257

Despite the misgivings of some of their white counterparts, the Indian soldiers would soon have an opportunity to prove their worth in the field. On June 21 , Col. Weer gathered his various regiments around Fort Scott, including the First and Second Indian Home Guards, and marched south towards Baxter Springs, near the Cherokee line. Weer intended to link up with the Union force still at Baxter Springs, then "push on rapidly... until I am in the close neighborhood of the enemy." 258

While Weer marched to unite his command, those troops still already stationed at Baxter Springs continued to wait. The soldiers' no longer waxed poetic about the beauty of the Spring River region; instead, rising temperatures and boredom made the men restless. "Sweating, choking, broiling as we do here in Southern Kansas," one Ohio trooper complained, "with dusty roads under our feet, tropical prairies on every side...dreaming of Cherokees, rattlesnakes, and short rations, you need not wonder that we sometimes long for a snuff of the pure lake breeze." By mid-June, temperatures began skyrocketing above 100-110 degrees. "Think of it!" the exasperated trooper groaned, "hot at noon, hot at night, and hot in the morning. Vulcan, it seems to me, could almost do his smithing, or Thor forge his thunderbolts in such a temperature."259

Under the sweltering Kansas sun, the men could only wait for their new commander to arrive and the expedition to begin. One trooper predicted the soldiers would stay put until 1862.

${ }^{257}$ Zimmer, Michael Zimmer's Diary, 131; “Parade Rest,” Fort Scott Bulletin [Fort Scott, KS], June 21,

${ }^{258}$ William Weer to Thomas Moonlight, June 13, 1862 and June 23, 1862, Official Records 13, 430-431, 445. By late June, the First Indian Home Guard enjoyed a full complement of ten companies, and the Second Home Guard contained seven companies, although Col. Weer remained confident that Osages would fill up the Second once the expedition reached southeast Kansas.

259 "From the Second Cavalry," Cleveland Morning Leader, June 26, 1862. 
"definitely ascertained among wrangling Kansas politicians who shall be greatest in the kingdom of Heaven, and lead this expedition where there is a full grown enemy." Amidst "the magnificent but lonely distances of this Dixian realm," Captain Alvred Nettleton of the $2^{\text {nd }}$ Ohio admitted "our part of the war is rather stale." One homesick Wisconsin soldier even committed suicide, leaving behind a wife and five children. The solitary interlude at Baxter Springs proved an unhappy one. Yet Captain Nettleton consoled himself that "Not every regiment...can indulge each day in a Marathon before breakfast, a Solferino as siesta, and a Shiloh in the evening. On the great chess-board there are many pawns_-yes even valiant knights, that may never take a piece, but all are working to the same end — the final checkmate." Though hardly destined for a Solferino or Shiloh, by the end of June, the long wait was over. The entire Indian Expedition gathered in Baxter Springs, finally ready to invade Indian Territory. ${ }^{260}$

On the night of June 27, the evening before the expedition's outset, white soldiers gathered to witness their Native American counterparts perform a war dance. "Eager to see a War Dance," Jacob Haas of the $9^{\text {th }}$ Wisconsin seemed taken by the thrilling event. Entering in a "grave procession," bodies painted and fastened with bells, feathers, and trinkets, the Indians encircled a large bonfire and danced. To the German Haas, the Indians' "bloodchurning shrieks, beating of drum and jingling of bells, in the sheen of the fire colorfully painted and yelling like demons, they looked like a host of crazy devils from the lower regions of hell.” Michael Zimmer

260 "From the Second Cavalry," Cleveland Morning Leader, June 26, 1862; Zimmer, Michael Zimmer's Diary, 130-131; "From the Second Cavalry—The Indian Expedition," Cleveland Morning Leader, June 23, 1862. Michael Zimmer periodically recorded the temperature in his diary prior to and during the expedition, as did several other soldiers. On June $17^{\text {th }}$, Zimmer recoded the temperature as $106^{\circ}$, and on June 24 at $110^{\circ}$ in the shade. The suicide was committed by Ludwig Salzwedel, a fifty-one year old private from La Crosse in Company F, $9^{\text {th }}$ Wisconsin. Though details as to why Salzwedel killed himself, Zimmer's diary states that he left a note that "remarked that he wanted to put an end to this life and humbug." A later newspaper account in the Daily Wisconsin of Milwaukee noted that an "investigation proved that he was subject to fits of mental aberration, thinking to intensely of home and its various enjoyments." Salzwedel was buried "on the green prairie not far from the clear and swift Spring river," and today his name is etched on a Civil War monument in Baxter Springs. Zimmer, Michael Zimmer's Diary, 130. 
confessed it "awful to see how they brandish their tomahawks while they jump around the fire."

A fearsome spectacle to the white soldiers, for the Native Americans, the dance was an important ritual promising protection and success in the coming days. ${ }^{261}$

While the expedition danced, William Weer cut his opening orders for the campaign. The Indian Expedition was divided into two brigades. The First Brigade was led by Colonel Frederick Salomon and consisted of Salomon's $9^{\text {th }}$ Wisconsin Infantry, the $2^{\text {nd }}$ Indian Home Guards, $2^{\text {nd }}$ Ohio Cavalry, and Rabb's Indiana Battery. Col. William Judson commanded the Second Brigade, composed of Judson's own $1^{\text {st }}$ Indian Home Guard, the $10^{\text {th }}$ Kansas Infantry, $6^{\text {th }}$ and $9^{\text {th }}$ Kansas Cavalry, and Allen's Kansas Battery. Salomon's First Brigade would depart south on the morning of the $28^{\text {th }}$; Judson's brigade would follow suit on the $29^{\text {th }}$. The brigades would cross Grand River at Hudson's Ferry and rendezvous at Cowskin Prairie, the site of Col.

Doubleday's victory some three weeks prior. Weer ordered scouts to "scour the country between Grand River and the Missouri State line" to guard the expedition's eastern flank. ${ }^{262}$

At 1 a.m. on the morning of June $28^{\text {th }}$, reveille sounded throughout the Federal camps and soldiers stirred, and by 3 a.m. the Expedition's First Brigade was marching south across a "landscape desolate and wild." In an omen of weather to come, the temperature on the first day of the march soared to $120^{\circ}$. The following day brought a respite of only $110^{\circ}$ in the shade. Michael Zimmer thought the weather "very hot," and Colonel Salomon reported the brigade

${ }^{261}$ Haas, This Day We Marched Again, 30-31; Zimmer, Michael Zimmer's Diary, 131. Haas' account of the war dance is extensive and detailed. The Native American soldiers of the Indian Home Guard performed a number of war dances immediately prior to and during the expedition. After separating the regiments from their refugee families in mid-June, Weer reported that they held "a grand 'war dance.' They have all taken their medicine and consider themselves bullet-proof." Besides the war-dance of the $27^{\text {th }}$ at Baxter Springs described above, Isaac Gause of the $2^{\text {nd }}$ Ohio Cavalry recalled several more dances "the night before the battle of Round Prairie, and also at Flat Rock Creek" during the expedition. William Weer to Thomas Moonlight, June 13, 1862, Official Records 13, 430; Gause, Four Years with Five Armies, 84.

262 James A. Phillips to Frederick Salomon, June 27, 1862 and James A. Phillips to W.R. Judson, June 28, 1862, Official Records 13, 452, 456. 
"suffered greatly during the march on account of the extreme heat and for want of water." Yet the expedition made rapid progress. Salomon's First Brigade pushed south on the east side of the Grand River, while Judson's Second Brigade mirrored the movement from the west side. Sweeping the countryside as the marched, they netted a few prisoners and livestock, and by the $29^{\text {th }}$ the two brigades reunited at Round Grove (east of Grand River) on Cowskin Prairie, near the battlefield from a month prior. Upon arrival, they discovered a small Confederate scouting party of 150 men observing their movements, but the enemy disappeared upon approach. The expedition made camp at Round Grove, yet reports of larger Confederate forces in the vicinity kept the expedition on guard. ${ }^{263}$

Following in the wake of the Indian Expedition were hundreds of Indian refugees, primarily Creeks and Seminoles, who believed the expedition would liberate Indian Territory and allow them to return home. Unfortunately, records shed only little light on the experiences of these returning refugees. Their absences from Union soldiers' correspondence and diaries suggests that they did not follow the Expedition's columns directly, but rather made their own way home. If these Creeks and Seminoles were to successfully resettle, the Expedition would need to oust the Confederates from their strongholds around the Arkansas River and drive them

263 Zimmer, Michael Zimmer's Diary, 131-132; Frederick Salomon to William Weer, June 30, 1862, 458, and William Weer to Thomas Moonlight, July 2, 1862, Official Records 13, 459-461; Banasik, ed, Reluctant Cannoneer, 45. When the expedition set out from Baxter Springs, reports reached Weer of a Rebel force under General Rains marching towards Neosho, Missouri, the seat of Newton County less than 30 miles away. A detachment of the $2^{\text {nd }}$ Ohio Cavalry was already stationed at Neosho, and Weer sent four companies of the $9^{\text {th }}$ Wisconsin and a section of Rabb's Indiana Battery to their relief. The reports proved false, and the small detachment of the $2^{\text {nd }}$ Ohio, $9^{\text {th }}$ Wisconsin, and Rabb's battery marched south, rejoining the expedition at Cowskin Prairie by July $1^{\text {st }}$. The expedition paused at Cowskin Prairie from the afternoon of June $29^{\text {th }}$ through July $1^{\text {st }}$ to allow for the Neosho detachment to arrive. The whole affair also illuminates Weer's sensitivity to the possibility of Confederate activity to his eastern flank and rear, hence his cautious two-pronged advance down both sides of the Grand River. In his diary, Michael Banasik recorded that John Coffee's, James Rains', and Thomas Livingston's Missouri companies skulked in the vicinity. William Weer to Thomas Moonlight, Official Records, 13, 459-460; Zimmer, Michael Zimmer's Diary, 132-133; Tenney, War Diary, 19. 
back beyond the Canadian, thus liberating Cherokee, Creek, and Seminole Nations. It was a tall task. $^{264}$

Fortunately, the Rebels lurking around the Indian Expedition in the summer of 1862 belonged to a variety of hodge-podge Confederate outfits, the product of a confused, poorlyorganized Confederate command structure. The Confederate Department of Indian Territory was led by Albert Pike, the portly, officious Arkansas lawyer responsible for the negotiation of the Confederate treaties with the Five Tribes. As a reward for his diplomatic endeavors, Pike was promoted to brigadier general and given command of the Indian department. In his early tenure, however, Pike was an absentee commander; in November of 1861 he departed for Richmond to submit the negotiated Indian treaties to the Confederate government for approval. His departure proved untimely (or perhaps fortuitous, given Pike's limited abilities as a military commander), and he missed Opothleyahola's Rebellion entirely. He returned in time to lead the Indians through their poor performance at Pea Ridge, where he himself revealed his own inadequacies as a commander. $^{265}$

Despite his limited military experience, Pike styled himself something of a generalissimo. In the spring of 1862 , he developed a strategy that effectively removed him from the front and gravely endangered Confederate Indian Territory. In the wake of the Confederate defeat at Pea Ridge, Federal forces secured their foothold in Northwest Arkansas. The Federal presence

${ }^{264}$ Britton, Union Indian Brigade, 62; Lary C. Rampp and Donald L. Rampp, The Civil War in the Indian Territory (Austin, TX: Presidial Press, 1975), 15; Edward Everett Dale, "The Cherokees in the Confederacy," Journal of Southern History 13, no. 2 (May, 1947), 159-185. Wiley Britton states that refugee Indians began gathering in Baxter Springs prior to the Expedition's onset and then accompanied it south at least to Hudson's Crossing along the Neosho; he places the number in the hundreds. Edward Dale puts the refugee figure at 1,500, but he doesn't cite a source for this figure. This number is repeated in Larry and Donald Rampp's work.

${ }^{265}$ Walter Lee Brown, A Life of Albert Pike (Fayetteville: University of Arkansas Press, 1997), 372-373. Pike departed for Richmond despite knowledge of the growing dissidence among the Creeks regarding the Confederate-Creek Treaty, and the mobilization of rebellious Creeks under Opothleyahola. 
undoubtedly weakened the Confederate position in neighboring Indian Territory, but in Pike's mind, Federal occupation of Northwest Arkansas invalidated any Confederate defense of Indian Territory north of the Canadian River. Pike promptly retreated over one hundred miles south deep into Choctaw Nation and began constructing an immense earthen fortification-dubbed Fort McCulloch — along the banks of the Blue River. Pike's command was barely twenty miles from the Texas border, and 150 miles from the Kansas line. ${ }^{266}$

In Albert Pike's mind, his strategy presented the best opportunity to defeat any inevitable Federal invasion of Indian Territory, an invasion which could threaten Texas or southern Arkansas. "The country south of the Canadian offers much better positions for such an action than north of it," Pike explained in June from Fort McCulloch, "and the nearer Texas it is fought the better." Pike's proximity to Texas further allowed him to quickly gather reinforcements in case of invasion, and besides, "there will be not time to erect [fortifications] at any point north of this post." In short, Pike took his 3,000 man command and withdrew into a defensive shell, much too far south to challenge Weer's pending invasion. Pike's task as commander of the department was to defend the Indian nations, as promised by the treaties Pike himself negotiated the previous summer. Although Pike claimed, "If I can prevent the Indian country from being occupied by the enemy I shall be content," in reality, by electing to fight along the Blue River, Pike left most of Indian Territory defenseless. ${ }^{267}$

${ }^{266}$ William P. Corbett, "Confederate Strongholds in Indian Territory: Forts Davis and McCulloch," Early Military Forts and Posts in Oklahoma, edited by Odie B. Faulk, Kenny A. Franks, and Paul F. Lambert (Oklahoma City: Oklahoma Historical Society, 1978), 71, 73.

${ }^{267}$ Albert Pike, "General Orders No._,", June 23, 1862, Official Records 13, 839-840; “Abstract from Return of the Department of Indian Territory," Official Records 13, 831. Pike's command consisted of the $22^{\text {nd }}$ Texas Cavalry Regiment (Robert Taylor), $34^{\text {th }}$ Texas Cavalry (Almerine Alexander), the $19^{\text {th }}$ Arkansas Infantry (C.L. Dawson), and two Arkansas artillery batteries under Captains West and Woodruff. Fort McCulloch contained nineteen artillery pieces. Pike also had two small companies of Arkansas and Texas cavalry. On paper, Pike's command numbered 3,036, but attrition via desertion and illness brought his effective force down to 1,579. Despite their haggard condition and low morale, these forces represented the only infantry and artillery commands in Indian Territory in 1862 . 
The lunacy of Pike's strategy was apparent to everybody except him. General Thomas Carmichael (T.C.) Hindman, the spry, energetic Arkansan placed in command of the TransMississippi Department in May, admitted that Pike's "force does not amount to much, but there is no earthly need of its remaining 150 miles south of the Kansas line throwing up intrenchments." Pike's soldiers, suffering from sickness and low morale, concurred with Hindman's critique. Upon reaching "the so called Head Quarters" of Pike's fort, Arkansan Joseph Farr confessed to his wife, "I began to fear that we would never overtake old Pike in his chase. But I believe he has finally come to the conclusion that he is far enough out of the way[.] We are only 20 miles from the Texas line." 268

Pike's southerly post worried chiefs and commanders to the north. Cherokee Chief John Ross pleaded to Jefferson Davis of the "unprotected state of the country," since Pike's command was "not far north of Red River, in the Choctaw Nation, and more than 200 miles south of the northern boundary of the Cherokee Nation." Col. Douglas Cooper subtly critiqued Pike when he reported "we are likely to resort to guerrilla warfare at least those who are outside the new lines of defense." Cooper's further forewarned, “As matters now stand, if a Federal force should

268 T.C. Hindman to Samuel Cooper, June 19, 1862, Official Records 13, 836-837; Joseph Farr to Sallie Farr, April 26, 1862, Joseph G. Farr Civil War Papers, Butler Center for Arkansas Studies (hereinafter referred to as BCAS), Little Rock, AR. From Fort McCulloch, Farr also reported "a great deal of sickness in the Regmt. more sick than well." Although Farr did not enlist in the $19^{\text {th }}$ Arkansas, he accompanied them to Indian Territory and belonged to a company that would later join the $24^{\text {th }}$ Arkansas Infantry (Col. Portlock). Hindman sensed these troops were of little value in Choctaw Nation, and facing a dire manpower shortage back in Arkansas, Hindman ordered Pike to send all of his white soldiers and Woodruff's battery to Arkansas on May $31^{\text {st }}$. Pike unsurprisingly balked, grousing that "your order destroys all my plans, paralyzes all my efforts, and finishes the ruin of the command." From Pike's perspective, the slow stripping from his command both men and material was an affront. For Hindman, however, Pike's recessed position was simply a waste of much-needed manpower. Nevertheless, Pike complied and ordered Dawson's $19^{\text {th }}$ Arkansas Infantry and Woodruff's Battery to Little Rock on June 8 (upon receipt of Hindman's order). T.C. Hindman to Albert Pike, May 31, 1862, Albert Pike to T.C. Hindman, June 8, 1862, O.F. Russell, "General Orders No._." June 8, 1862, C.L. Dawson to T.C. Hindman, June 20, 1862, Official Records 13, 934, 936-943, 945-946. 
advance into Cherokee country I think Stand Watie would be driven out and a large majority of the Cherokees go over to the Federals." Cooper's words proved prophetic. ${ }^{269}$

The June gathering of Federal forces in southern Kansas did not go unnoticed by the Confederates. Increasingly concerned over the possibility of imminent invasion, in mid-June General Hindman ordered Pike to move towards Cherokee Nation "and establish his headquarters at Fort Gibson." Pike declined, instead granting to Col. Douglas Cooper command of "all the Confederate and allied troops north of the Canadian River," which essentially gave Cooper control over the few mounted Indian regiments in the region. In the case of Federal invasion, Cooper was to "concentrate his troops on their flanks and front, impede their march as greatly as possible, and draw them so far into the country that if defeated retreat may be ruinous to them." Cooper was not to risk battle "if success is doubtful." Unaware that Pike was still at Fort McCulloch, or that Pike placed Cooper in charge of Cherokee Nation's defense, on June 26, General Hindman placed Missouri Colonel J.J. Clarkson in command of all forces in the Cherokee, Creek, and Seminole Nations until Pike arrived. Thus, when the Federals invaded Indian Territory a few days later, the local Confederate command structure was muddled, and Generals Pike's forces had yet to depart Fort McCulloch. Over the next few days, the Federal Indian Expedition exploited their enemy's confusion. ${ }^{270}$

\footnotetext{
${ }^{269}$ John Ross to Jefferson Davis, May 10, 1862, Papers of Chief John Ross 2, 512-513; Douglas Cooper to Earl Van Dorn, May 6, 1862, Official Records 13, 823-824. Although not his commanding officer, Cooper took "the liberty" of reporting to Van Dorn as Pike was "near Fort Washita, at Nail's Bridge, 175 miles southwest." Cooper's disapproving tone in unmistakable.

${ }^{270}$ T.C. Hindman to S. Cooper, June 19, 1862,Albert Pike, "General Orders No._," June 23, 1862, and R.C. Newton, "General Orders No. 21," June 26, 1862, Official Records 13, 836-837, 839-840; Henry Buckner to Mollie Buckner, July 2, 1862, Reverend Henry F. Buckner Collection, Oklahoma Historical Society (hereinafter referred to as OHS), Oklahoma City, OK. Hindman's correspondence isn't clear about what date he issued orders for Pike to move to Fort Gibson, but Pike's correspondence intimates that Hindman ordered Pike to Fort Gibson on June 17, an order only received by Pike on the evening of June 24. Some confusion also exists as to whether Colonel Clarkson ever knew he had been appointed to command. David Haimerl has posited that it is unlikely Clarkson knew of his appointment by the time of Locust Grove. Regardless, there's little doubt the command situation was muddled. Clarkson and Watie seemed to be cooperating, albeit ineffectively (as the coming engagement at Locust Grove would show), and Cooper was not yet on hand to exert command. Albert Pike to T.C. Hindman, June 24,
} 
On July $2^{\text {nd }}$, the expedition lurched southward from their temporary camp at Cowskin Prairie. As the Federals approached Cabin Creek at nightfall, reports reached Colonel Judson, commander of the Second Brigade, of Confederate activity in the area. It was rumored that Stand Watie's Cherokees had only recently departed the vicinity and left their supply train at Locust Grove, a small post over thirty miles away on Cabin Creek. Anxious to clash with the enemy, Judson put together a small force of 300 men, consisting of detachments from the $1^{\text {st }}$ Indian Home Guard (mounted), $9^{\text {th }}$ Kansas Cavalry, $10^{\text {th }}$ Kansas Infantry (loaded into wagons), and a section of Allen's Kansas Battery. The arrival of Colonel Weer at Cabin Creek, however, displaced Col. Judson from command, as Weer elected to personally lead the attack on the enemy train. Among the small force was Major Albert Ellithorpe, the Chicagoan who had yet to see combat. With soldiers "piled promiscuously into wagons," the tiny Federal force set out on an impressive overnight march of thirty-five miles. Efforts were made to ensure secrecy; Indian men in their homes were arrested to keep from alerting the Confederates. At a pair of these homes, however, detachments of the $6^{\text {th }}$ Kansas Cavalry startled and scattered a party of Rebel scouts "like chaff before the wind." Although the Kansans captured ten of the enemy, others fled into the brush, threatening to sound the alarm at Locust Grove of the Federal advance. Unsure of whether the Confederates knew of their advance, by sunrise the blue-clad command reached Locust Grove unmolested. ${ }^{271}$

1862, Official Records, vol. 13, 947-950; David Haimerl, Clarkson's Battalion, C.S.A.: A Brief History and Roster (Independence, MO: Two Trails Publishing, 2005), 62-64.

271 "Reports of Col. William Weer," July 4 and 6, 1862, Official Records 13, 137-138; "From the Cherokee Nation," Lawrence Republican, July 17, 1862; Theodore Gardner, "The First Kansas Battery: A Historical Sketch, with Personal Reminiscences of Army Life, 1861-'65," Collections of the Kansas State Historical Society, 19151918, vol. 14, edited by William Connelley (Topeka: Kansas State Printing Plant, 1918), 239-240; Johansson, ed., Albert C. Ellithorpe, 25-26. The command specifically consisted of a section of Allen's Kansas Battery under Lieut. Baldwin and Lieut. Taylor (Weer's chief of artillery), several hundred Indians (mostly Creeks) under Lt. Col. Wattles and Major Ellithorpe, 68 men from the $10^{\text {th }}$ Kansas Infantry under Captain Quigg, Companies D, E, and H 
The Confederate force at Locust Grove was comprised of seventy-five Missourians under the command of Col. J.J. Clarkson. Originally an officer of the pro-Confederate Missouri State Guard, Clarkson and his men had only recently mustered into Confederate service. Operating in Indian Territory that summer, their presence was meant to reassure Confederate Cherokees of the Confederacy's commitment to their nation. Yet Clarkson's presence only complicated an increasingly fragmented Confederate command structure. As June turned to July, Clarkson fell ill. Knowing the Federals were approaching, Clarkson gave Stand Watie most of his Missourians, retaining only a small company of seventy-five to guard the Rebel baggage trains on a small hill near Locust Grove. Although Clarkson explicitly ordered Watie to "cross to the west side of Grand river and watch the enemy," Watie failed to carry out the orders. In fact, Watie's men briefly encountered the $6^{\text {th }}$ Kansas Cavalry on the east side of Grand River on July 3 and skirmished with them at Spavinaw Creek. Though a trifling affair resulting in a lone Rebel casualty, the fight at Spavinaw Creek assured that Clarkson's command was unsupported and dangerously exposed to the advancing Federals on the morning of July 3, 1862. ${ }^{272}$

The Union force approaching Clarkson's camp that morning did so without a leader. During the overnight march, Col. Weer "made frequent visits to his bottle \& the nearer we approached the enemy the greater his excess." Major Ellithorpe confided to his diary that "by the

of the $9^{\text {th }}$ Kansas Cavalry under Major Bancroft, and perhaps a dozen men of Company F, $6^{\text {th }}$ Kansas Cavalry under Captain Schaurte. The resulting engagement is also referred to at times as the Battle of Grand Saline, in reference to nearby salt-producing springs. Locust Grove was the name of a nearby post-office.

272 J.J. Clarkson to Samuel Cooper, February 29, 1864, Civil War Collection, 1860-1977, Missouri Historical Society [digitized]. Fighting in southeast Missouri that summer, especially between Missourians and Watie's Cherokees at Neosho, increased guerrilla activity in the region. Various Missouri State Guard units, including the commands of John T. Coffee, James Rains, and J.J. Clarkson all sought refuge in Cherokee Nation at various points in time that summer. Coffee's men were near Watie's camp during the June fight at Cowskin Prairie, and Clarkson's men were involved at the clash at Locust Grove in July. While Clarkson was routed by Weer, the engagement along Spavinaw Creek was a running affair between Colonel Jewell's $6^{\text {th }}$ Kansas and Watie's $2^{\text {nd }}$ Cherokee; at one point, Kansan troopers almost caught Watie, and "emptied their revolvers at him without effect." The Rebels suffered only one casualty at Spavinaw Creek but were thoroughly dispersed. Britton, Union Indian Brigade, 65. 
time the attack was made he [Weer] was in no condition to give an order." Ironically, however, Weer's Confederate counterpart may well have been inebriated himself. Col. Clarkson had apparently been warned of the Federals approach — perhaps by those men who escaped the clutches of the $6^{\text {th }}$ Kansas Cavalry overnight—-but Clarkson and his officers took no action; rumors flew they may have been "too drunk to attend to their duty." Thus, the two forces were possibly commanded by a pair of intoxicated colonels. ${ }^{273}$

Leaderless, the Federals nevertheless advanced toward enemy's camp, located "upon the summit of a hill, in the midst of a thicket." Finding themselves in the vanguard of the Federal advance as they approached, Lt. Col. Wattles and Major Ellithorpe of the $1^{\text {st }}$ Indian deployed their mounted Indians and led the Creeks in a three-hundred yard charge up a "steep hill" just as the sun rose on the horizon. The $9^{\text {th }}$ Kansas Cavalry quickly joined in support, sensing "a fair chance to try their hand." Due to "utter disregard" or drunkenness by Colonel Clarkson, there were no Confederate pickets on guard, and the "attack threw the enemy into great consternation." Although the "enemy commenced fire as soon as we rose over the brow of the hill," Confederate shots sailed high. The mounted Indians and Kansans swept through the Rebels' encampment, and "the enemy broke ranks and fled in terrible confusion, leaving every thing pertaining to their

\footnotetext{
${ }^{273}$ Johansson, ed., Albert C. Ellithorpe, 25-26; "From the Cherokee Nation," Lawrence Republican, July 17, 1862; "From the Indian Expedition," Lawrence Republican, July 31, 1862; Stephen Foreman diary, July 3 and July 4, 1862, Stephen Foreman Papers, WHC, OU. Weer was almost certainly drunk, as several sources corroborate. The charge that Clarkson was inebriated stems from Stephen Foreman's July 4 diary entry. Foreman recorded that Clarkson's command either didn't believe the reports of the Federals' advance or were too drunk to respond. The rumor drunkenness is marginally supported by the memoirs of Brig. Gen. Sidney Drake Jackman, a Missouri commander who served alongside Clarkson in the Missouri State Guard. Jackman, who misremembers Clarkson as "Clarkston," wrote that Clarkson was "given to dissipation [and] spent most of his time drunk and lying in his ambulance." Jackman further claims Clarkson was drunk in his wagon upon capture at Locust Grove, and was driven from the battlefield while he was unconscious. The latter detail seems unlikely, and somewhat calls into question the validity of Jackman's account. Nevertheless, between Foreman's diary and Jackman's memoirs, a case can be made the Clarkson was indeed intoxicated at Locust Grove. Jackman, Sidney Drake. Behind Enemy Lines: The Memoirs and Writings of Brigadier General Sidney Drake Jackman, edited by Richard L. Norton (Springfield, MO: Oak Hills Publishing, 1997), 54.
} 
command." The whole affair was over quickly, before the infantry or artillery could even fire a shot. $^{274}$

Despite Weer's inebriation, the Locust Grove skirmish proved quite the little coup. The Federals killed several Confederates and captured approximately 100 prisoners, including Colonel Clarkson himself. Only three Union soldiers were killed, privates of the $1^{\text {st }}$ Indian and $9^{\text {th }}$ Kansas, along with an assistant surgeon whose civilian garb led to his accidental shooting. Adding to the victory were the captured goods: horses and mules, 1,500 head of cattle, thirty wagons, 500 small arms, ammunition, and more. One special piece of loot was the diary of George Falconer, one of Clarkson's Missourians, found by Albert Ellithorpe amidst the detritus of the enemy's camp. Confiscating the journal for his own use as "one of the trophies taken this morning," Ellithorpe gleefully wrote, "So hasty was the flight [of the enemy] that the cooking vesels were left upon the fires and their whiskey, todys ready prepared and untouched." Ellithorpe reckoned the value of the captured train at $\$ 100,000 .{ }^{275}$

Having routed the enemy, the victorious Federals now attempted to rouse their drunken commander. Only after the short battle did Weer manage to survey the battlefield in a "state of intoxication." Yet "overcome either by fatigue, the glory of the victory, or by the effects of certain hospital stores, the commander soon subsided to his ambulance, and became practically non est." The officers ineffectually tried to reawaken Weer but grew nervous at the isolated nature of their position; the fleeing members of Clarkson's command might well be raising the

${ }^{274}$ Johansson, ed., Albert C. Ellithorpe, 25-26; "From the Cherokee Nation," Lawrence Republican, July 17, 1862; "From the Indian Expedition," Lawrence Republican, July 31, 1862; Stephen Foreman diary, July 4, 1862, Stephen Foreman Papers, WHC, OU. Foreman, who reported on the affair days later in his diary, claimed that as soon as Clarkson's men surrendered, the colonel "told his men to run and take care of themselves."

275 "Reports of Col. William Weer," July 4 and 6, 1862, Official Records 13, 137-138; "From the Cherokee Nation," Lawrence Republican, July 17, 1862; "From the Indian Expedition," Lawrence Republican, July 31, 1862; Johansson, ed., Albert C. Ellithorpe, 25-26. 
alarm elsewhere. "Our position was a critical one," Ellithorpe recalled, and the officers agreed to mount up and return to the main expeditionary force on Cabin Creek. After travelling ten miles, Col. Weer finally awoke and ordered the little detachment to halt. Instead of traveling back to the main encampment, Weer simply ordered the detachment to make camp at the nearby juncture of Cabin Creek and Grand River, while he cut orders for the Indian Expedition's main force to join $\operatorname{him}^{276}$

With a tidy victory in hand, Weer determined to "lay by on the $4^{\text {th }}$ to celebrate the day." The holiday gave the colonel another excuse to continue his drinking spree, and indeed, the entire Indian Expedition took the opportunity to revel and imbibe along the banks of the Grand River. The expedition's artillery fired celebratory rounds. The $9^{\text {th }}$ Wisconsin's band played. A fight broke out among two soldiers in the $2^{\text {nd }}$ Ohio. Indians plundered the captured goods from Locust Grove. Soldiers feasted upon bean soup and boiled beef, and partook of "the Sutler's whiskey at $\$ 1$ a quart." Sergeant Luman Tenney of the $2^{\text {nd }}$ Ohio Cavalry, a thoughtful, prudent man, was "disgusted" by the behavior of the men. "Great day. So many drunk. Officers gave the freest license to the men," Tenney scorned. "One officer even told his men that the one who wasn't drunk that night should be ducked in Grand river...One reason everybody like Colonel Doubleday so well," Tenney reminisced, "was that he never drank."277

The fight at Locust Grove and the accompanying Independence Day revelries revealed the great flaw underlying the Indian Expedition of 1862. As Albert Ellithorpe opined, "The great mishap of this expedition so far is the inefficient and unreliable character of the officer in

\footnotetext{
${ }^{276}$ Johansson, ed., Albert C. Ellithorpe, 25-26; "From the Indian Expedition," Lawrence Republican, July 31, 1862; Britton, Union Indian, 66.

${ }^{277}$ William Weer to Thomas Moonlight, July 2, 1862, Official Records 13, 459-460; Haas, This Day We Marched Again, 33; Britton, Union Indian Brigade, 66; "Interesting Letter from the Ninth Wisconsin Regiment," Quiner Scrapbooks, Vol. 8, 58-59, WHS; Tenney, War Diary, 20-21.
} 
command (Col Wm Weere)." However capable when sober, Weer's predilection for alcohol undermined the discipline and efficiency of the expedition, eventually to the point of its endangerment. Weer's drinking had few consequences when the expedition was well-supplied and frolicking on the banks of the Grand River, with the enemy far away. Yet Weer's faults grew dangerous as the environmental, logistical, and strategic situation darkened in days ahead. ${ }^{278}$

For such a small skirmish, Locust Grove produced another great impact on the Expedition and Indian Territory. In the wake of the engagement, the few remaining members of Clarkson's Missouri Battalion fled southward. Arriving in the Cherokee capital of Tahlequah, some thirty miles south, word quickly spread of the disaster at Locust Grove and the Federal advance. Stationed at Park Hill were several companies of John Drew's $1{ }^{\text {st }}$ Cherokee Mounted Rifles. Comprised primarily of full-blooded Ross supporters, many of whom belonged to the secretive Keetowah Society, Drew's troopers possessed little devotion to the Confederacy. The Federal army was in the vicinity, had routed a Confederate command, and captured Col. Clarkson. The Confederate Cherokees' loyalty faltered. Repeating the defections of the winter previous, Drew's regiment melted in the face of the enemy. Hundreds of Confederate Cherokees poured into the Indian Expedition's camp over the next few days. By July 6, 600 Cherokees had defected and were enlisting in the rapidly filling-up $2^{\text {nd }}$ Indian Home Guard. "Our little victory has had a wonderful effect upon the Cherokees," Weer crowed, "deciding all the wavering in our favor...I consider the Cherokee country as virtually conquered."279

${ }^{278}$ Johansson, ed., Albert C. Ellithorpe, 26.

${ }^{279}$ Gaines, Confederate Cherokees, 102-104; William Weer to Thomas Moonlight, July 6, 1862, Official Records 13, 137-138; Dr. James Greene Walker diary, July 8 and 11, 1862, James Greene Walker Collection, Gilcrease Institute; Banasik, ed., Reluctant Cannoneer, 46-47. Robert McMahan recorded that a company of Cherokee Indians surrendered on the morning of July 3 and another 400 on July 4 . On July 4, Michael Zimmer similarly reported, "Today 400 Indians of the Cherokee Nation arrived. They brought three flags of the enemy with them and reported voluntarily as prisoners." Weer also reported 400 Cherokees defecting, with another 200 en route on July 6. On July 5, Colonel John Ritchie, commander of the $2^{\text {nd }}$ Indian Home Guard, reported that with the Cherokee defections, his regiment had nearly reached its complement of 1,000 men. Ritchie ordered three 
The defection of John Drew's Cherokee regiment had been all but assured. The regiment's wavering Confederate loyalties were exposed during the winter campaign against Opothleyahola. In the wake of the Pea Ridge debacle, discontent within the regiment continued to mount, as did tensions with the pro-Confederate Cherokees of Stand Watie's regiment. Stephen Foreman, a Cherokee minister of mixed ancestry and Southern supporter, confided in his diary in late June rumors of "a great deal of dissatisfaction" among Drew's Cherokees "because they feel restless as the time approaches for them all to go over to the Feds." Foreman further reported "the regiment has constant communication with the Fed army through those Cherokees who joined Opath-le-yah-ho-lah.” The rumors recorded by Foreman were true. Colonel Weer had been in contact with "a secret society of Union Indians called Ke-too-wah," whose reportedly numbered 2,000. Drew's ranks were littered with Keetowah members. ${ }^{280}$ Even more worrisome than possible collusion with the Federals was the possibility of outright civil conflict between Drew's and Watie's rival Cherokee regiments. Foreman heard wind of a plot "to cut off at one blow Col. Watie and his regiment, and all the half breeds who do not belong to the Ross Party." General T.C. Hindman, commanding the Trans-Mississippi department, grew concerned "that extreme ill-feeling, approaching nearly to actual collision, exists between the two Cherokee regiments." Given the possibility of violence against Watie's command, defection to the Federal lines may well have been the least injurious course taken by Drew's men that summer. ${ }^{281}$

companies of Cherokees to Fort Scott to be mustered in, and he also reported that 2,000 more Cherokees were expected in the coming days. "Our enemy is retreating. No large body is reported this side of Tahlequah." Zimmer, Michael Zimmer's Diary, 133; John Ritchie to James Blunt, July 5, 1862, Official Records 13, 463-464.

${ }^{280}$ Stephen Foreman diary, June 27, 1862, Stephen Foreman Papers, WHC, OU; William Weer to Thomas Moonlight, June 13, 1862, Official Records 13, 430-431.

${ }^{281}$ Stephen Foreman diary, June 27, 1862, Stephen Foreman Papers, WHC, OU; T.C. Hindman to Albert Pike, July 8, 1862, Official Records 13, 857. 
The victory at Locust Grove and the defection of Drew's Cherokees gave William Weer confidence, and on the morning of July 6 the Indian Expedition left its Grand River encampment and penetrated deeper into Cherokee Nation. As the sun rose in sky, temperatures likewise surged. At least one thermometer accompanied the expedition southward with Dr. Louis Loehr, assistant surgeon of the $9^{\text {th }}$ Wisconsin. Soldiers of the expedition took part in the time-honored tradition of grousing about the weather, and readings on Loehr's thermometer often made the rounds about camp. As the blue-clad soldiers tramped along the "very stony and rough" road south on July 6 , the temperature reached $111^{\circ}$ in the shade. Ohio trooper Albert Houghton confessed to his father, "I think it was the hottest day I ever saw." Compounding the heat was the complete absence of water along the expedition's sixteen mile route. ${ }^{282}$

Over the next several days the expedition continued its march south along dusty roads, under blistering heat, with little or no water. Morale soured. A march of sixteen miles on July 7 brought the men to several "beautiful springs" with "very bad water." The fifteen mile hike on July 8 was made without any water at all. Tramping along the rocky road amid "clouds of this fine, black, prairie dust rendered our marches almost unendurable." "The weather has been, without one moment cessation, the hottest I ever saw," complained one Ohioan, "the thermometer ranging from 98 to 106 in the shade." Soldiers who fell out during the march to find water were punished; when one party of soldiers slipped off to a nearby stream, they "were driven from the spring without a drop of water to wet their parched tongues, and forced to march the remainder of the way under guard." Sergeants who went in search of water returned to find themselves demoted back into the ranks. The men grumbled that the "tyranny of some of our

\footnotetext{
${ }^{282}$ Albert Houghton to father, July 10, 1862, Albert Houghton Papers, Ohio History Connection Archives \& Library, Columbus, $\mathrm{OH}$ (hereinafter referred to as OHC); Hermann Schlueter diary, Paul Dolle Civil War Collection, BCAS [digitized]; Zimmer, Michael Zimmer's Diary, 134.
} 
officers was unendurable," and rumors floated around that during the march, Col. Weer "was said to be drunk all the time, by his own rum." 283

The final day's march on July 8 marked a dangerous low-point for the weary, overheated soldiers. The expedition awoke at 2 a.m. and set off by 3 , hoping to beat the heat to their destination, which Colonel Weer assured the men was "in a very pleasant place" where the command could "rest and recruit a few days." For twelve hours, the soldiers "suffered greatly" as they plodded south amid dust and $100^{\circ}$ weather "without one drop of water." Upon reaching their destination at Flat Rock Creek, "what did we find?" one trooper angrily recounted. "Nothing but a pool of putrid, stinking water, that was so nauseating and repulsive to both taste and smell, that our famished horses would scarcely touch it." Upon attempting to drink the water, the Ohioan got sick and "did not try it again." Jacob Haas likewise thought the water "all red and really unfit to drink," but admitted that "too many thirsty crowded around and it was almost impossible to get to the water. Many were glad to suck wet sand." Soldiers variously described it as "thick with 'frog-spittle,' and one-third hot," and "swamp water, worse than old mud-run water." Still, the soldiers drank. Sick soldiers riding in ambulances begged of thirst. Angering the men were rumors that Col. Weer learned from afternoon patrols that the site lacked water, but continued anyways. $^{284}$

Despite the lack of abundant, clean water, Col. Weer shockingly wanted to fortify the position, located on a prominent hilltop. Weer "had the idea of digging wells and fortifying said

\footnotetext{
${ }^{283}$ Haas, This Day We Marched Again, 33; Zimmer, Michael Zimmer's Diary, 134; "From the Second Cavalry," Western Reserve Chronicle [Warren, OH], August 6, 1862; "The Condition of the Second Cavalry," Cleveland Morning Leader; September 2, 1862; "From the 2d Ohio Cavalry," Western Reserve Chronicle, September 10, 1862. Luman Tenney recorded, "One Q.M. Sergeant was reduced to the ranks day before yesterday for going to a spring almost in our line of march.” Tenney, War Diary, 20-21.

284 "From the Second Cavalry," Western Reserve Chronicle, August 6, 1862; Hermann Schlueter diary, BCAS; Haas, This Day We Marched Again, 33-34; "The Condition of the Second Cavalry," Cleveland Morning Leader, September 2, 1862; "From the 2d Cavalry," Western Reserve Chronicle, August 20, 1862; McMahon, Reluctant Cannoneer, 47.
} 
sand hill—beautiful prospect for the summer season," Wisconsin Major Hermann Schleuter sardonically reported. "Boys called the camp=Camp Desperation." Weer's choice of location seemed especially cruel given the proximity of the Grand River only a few miles away, and the men travelled several miles that evening "hauling water from there as our only salvation." Bowing to human necessity, Weer moved the command several miles further to Grand River the next morning and went into camp. ${ }^{285}$

Unsurprisingly, the days of extraordinary heat and lack of water eroded the health of the Expedition's soldiers. "Many, very many of our poor fellows," reported an Ohio trooper, "have I seen drop down by the wayside, from the effects of sunstroke." Luman Tenney similarly reported his comrades had been "sunstruck" due to the "melting weather we have had." Disease and sickness took its toll. One correspondent despaired that "our men were sickening and dying very fast" due to the "boiling sun" and high temperatures, lack of good water, and fatiguing marches, "all silently doing this work." Another trooper angrily blamed Weer for their struggles: "He marches the command with great rapidity, regardless of the suffering of his men and their increasing debility in this severe climate. ${ }^{286}$

Beast suffered alongside man, not only from heat, but from sun-withered grass that offered little nutrition. Private William Wildman reported to his father it was "very hot and dry, so dry that the grass is all drying up, the feed is not very big, nor it wont be without it rains soon.” Wildman admitted, “Our horses are very poor, they don't endure this climate like those that are raised here." Upon looking at his mare, "standing with her head down, too tired to eat,

\footnotetext{
${ }^{285}$ Hermann Schlueter diary, Butler Center for Arkansas Studies; "From the Second Cavalry," Western Reserve Chronicle, August 6, 1862; Zimmer, Michael Zimmer's Diary, 134.

286 "From the Second Cavalry," Western Reserve Chronicle, August 6, 1862; Tenney, War Diary, 20-21; "From the 2d Ohio Cavalry," Western Reserve Chronicle, September 10, 1862; "From the 2d Ohio Cavalry," Cleveland Morning Leader, August 5, 1862; McMahon., Reluctant Cannoneer, 50. Later in July, Robert McMahon noted in his diary, "Still very warm. Boys getting sick, something like sunstroke \& a very harmful dysentery."
} 
with the crust of dry sweat and dust that showed the hard usage," Ohio trooper Isaac Gause broke into tears. The expedition's horses, especially the un-acclimated Ohio mounts, were "giving out all the time, and were shot or abandoned." 287

The Indian Expedition was marching through an extraordinary hot summer. The highest temperature ever recorded in Oklahoma reached $120^{\circ}$ in 1936 . If the temperatures recorded by members of the expedition are accurate, the sweltering heat reached $120^{\circ}$ not once, but several times throughout the course of their campaign, perhaps even slightly exceeding that mark. Regardless of any single days' record-setting heat, it is apparent from letters and diaries that much of the expedition occurred under temperatures above $100^{\circ}$. These unusually broad temperatures fit into a larger pattern of unusual climate across the American South during the Civil War: draughts, searing summers, frigid winters, drastic precipitation, and other extreme weather conditions plagued the nation. The extreme heat of Indian Territory - a small part of this larger climatological trend-weakened Union soldiers, lowered morale, and eroded faith in Colonel William Weer. ${ }^{288}$

\footnotetext{
287 “From the 2d Cavalry," Western Reserve Chronicle, August 20, 1862; Isaac Gause, Four Years with Five Armies, 89-90.

${ }^{288}$ Oklahoma Climatological Survey, "State Records," http://climate.ok.gov/index.php/site/page/state_records; Kenneth Noe, "The Significance of Weather and Climate to Civil War History," 19-21. In his diary, Michael Zimmer recorded the following temperatures for the days prior to and during the expedition: June $17-106^{\circ}$, June $24-110^{\circ}$ (in the shade), June $28-120^{\circ}$ (first day of expedition's march south), June $29-110^{\circ}$ (in shade), July $19-115^{\circ}$, July $20-107^{\circ}$, July $21-117^{\circ}$, July $22-119^{\circ}$. Major Herrman Schlueter of the $9^{\text {th }}$ Wisconsin recorded a temperature of $100^{\circ}$ on July 8 , and on July 9 he wrote "Weather hot, thermometer on one day 118 degrees in the shade (in Dr. Lohrs tent.)." Henry Chester heard rumors that the temperature reached $120^{\circ}$. Albert Houghton told his father the temperature reached $111^{\circ}$ in the shade on July 6 . In a published letter to his father, William Wildman of the $2^{\text {nd }}$ Ohio complained of the "sun shedding its rays of heat upon us to the amount of 121 degrees in the shade." Correspondent "B." reported to the Western Reserve Chronicle in Ohio of the "thermometer ranging from 98 to 106 in the shade." Another Ohioan similarly recalled the "scorching rays of a sun which raises thermometer from $106^{\circ}$ to $115^{\circ}$." One unnamed Ohio correspondent even claimed the temperature reached $130^{\circ}$, though this almost unbelievable statistic has little else to support it. Supporting the soldiers' accounts is the diary of Reverend James Greene Walker. A Methodist reverend stationed in Tahlequah, Walker recorded temperatures of $103^{\circ}$ on June $26-27,105^{\circ}$ on June 29 , and $104^{\circ}$ on July 8 . Walker routinely remarked on both the heat and weeks of drought.

Collectively, these recordings suggest that the expedition struggled under intense heat. For the nine dates during the expedition for which we have specific data, the average temperature was $113^{\circ}$. For those dates without data, one might presume the temperature was lower, but still in the 90s or 100s. The hottest days of the expedition
} 
Arrival at Grand River on July 9 offered respite for the troops, who "eagerly climbed down and swam and refreshed ourselves" the creek's cool waters. The expedition's halt at that location owed itself to William Weer's ongoing correspondence with Cherokee Chief John Ross and Federal-Cherokee relations generally. On July 7, as his soldiers marched under the hot sun, Weer penned a formal message to Ross, informing Ross of his approach "with an armed force of regularly enlisted soldiers, instructed and prepared to enforce the observance of treaty obligations by the Cherokee people." Weer acknowledged that "a portion of the Cherokees have been seduced by designing men" into the Confederacy, but Weer hoped the expedition's presence would restore "good feeling and the observance of law and order in this beautiful country, now threatened with the horrors of civil war." Weer requested an audience with Ross to discuss bringing all Cherokees - pro-Union and pro-Confederate alike—-back under Federal authority. ${ }^{289}$

For weeks, Colonel Weer had been assured that John Ross and most of the Cherokees were truly loyal to the Union. Not long after assuming command in June, Weer confidently predicted, "John Ross is undoubtedly with us, and will come out openly when we reach there." The massive defections among Drew's Confederate Cherokees and the enlistment of hundreds of Cherokees into the $2^{\text {nd }}$ Indian Home Guard undoubtedly bolstered Weer's belief that the Cherokees would turn. It came as a surprise, then, when Ross politely declined Weer's offer almost immediately. Citing the Cherokees' existing treaty with the Confederacy, Ross could not honorably treat with Weer, and furthermore stated his belief that civil war "may be averted by the observance of the strict principles of civilized and honorable warfare by the army now

appear to be June $28\left(120^{\circ}\right.$, which would tie the Oklahoma state record $)$, July $9\left(118^{\circ}\right.$ in the shade, which suggests the temperature that day may have reached or exceeded $\left.120^{\circ}\right)$, July $21\left(117^{\circ}\right)$ and July $22\left(119^{\circ}\right)$.

${ }^{289}$ Haas, They Day We Marched, 34; William Weer to John Ross, July 7, 1862, Official Records 13, 464. 
invading our country under your command." Ross' unexpected response left Weer stymied and frustrated. ${ }^{290}$

Having heard reports of the Federal advance and Cherokee defections, Cherokee minister Stephen Foreman visited Chief Ross several times during Ross' deliberations over how to respond to Weer's communique. Foreman found Ross to be defensive and coy, with Ross claiming "one thing is clear, we should have to submit to superior power." Foreman suspected a plot. "I could not help thinking that Mr. Ross was secretly approving the course of the Pin party and publicly standing by the Treaty made with the Confederate States. Or in other words, he is trying to be a northern and southern man both at the same time." For Foreman, the truth of John Ross' loyalties lay in his actions. "If he is what he publically professes to be, a true Southern man, who have these Pins gone North?" Ross had done nothing to prevent the flow of defections to the Federal army. His mansion at Park Hill was guarded by Drew's Cherokees, and unlike many of his pro-Southern neighbors, neither Ross' property nor slaves had been molested or freed. For Foreman, this was evidence that Ross' imminent defection was planned, and "Mr. Ross and all of that stripe will go soon, as soon as the tricks are fixed for it."291

Stephen Foreman's suspicions regarding John Ross' true loyalties were well-founded, and many others-Northerners, Southerners, and Native Americans alike—suspected Ross of playing political games. The reality was that Ross' Cherokee-Confederate alliance has always

\footnotetext{
${ }^{290}$ William Weer to Thomas Moonlight, June 13, 1862, Official Records 13, 430-431; John Ross to William Weer, Papers of Chief John Ross, vol. 2, 515-516.

${ }^{291}$ Stephen Foreman diary, WHC, OU. Foreman visited Ross on July 7, the day Weer wrote Ross his message. Foreman found Ross to be defensive and claimed to be powerless over the situation. Foreman pressed Ross to issue a proclamation calling for united "in the defense of our interests," to which Ross responded "very cooly." On July 8, Foreman learned of the defection of three hundred Pin Indians, and in a chance encounter with Col. John Drew, learned that Ross had received Weer's letter the night previous. Foreman suspected the defections were "carrying out the place long since laid by Evan Jones and Chief Ross." On July 9, Foreman visited Ross again, and Ross accurately laid out the details of Weer's message. Foreman was unsatisfied with the visit, believing Ross was behind the defections. Foreman was one of many visitors that day, including a company of Pin Indians headed to the Northern army to defect, which Ross did nothing to prevent.
} 
been a marriage of convenience, not conviction. In the autumn of 1861, Ross finally backed the Confederacy for several reasons: the ascendency of Rebel arms (especially regionally), a desire to keep the Cherokee Nation and Five Tribes united in the face of a white mans' civil war, and as a way to cement his grip on the Cherokee chieftaincy over rival Stand Watie. By the summer of 1862, hardly any of those reasons still carried much weight. The Confederate defeat at Pea Ridge and the failure of the Confederacy to protect Indian Territory revealed the South to be a weak, unreliable ally. Opothleyahola's Rebellion in the winter of 1861 shattered any hopes of a united Indian Territory.

Worse, the Cherokee Nation itself seemed poised on the edge of civil war. Pin Indians and Watie men murdered and robbed each other across the countryside, and Drew's and Watie's regiments simmered with hostility towards each other. Drew's regiment, the pet regiment of Ross and his supporters, was defecting to the Federals by the hundreds. Watie's regiment lurked in the region, and Ross kept a guard at his house to protect him from the Federals, Watie's men, or both. The political and military ground was shifting under John Ross' feet. Ross' refusal to meet with Col. Weer was not a reflection of deep loyalty to the Confederacy, but rather a bid to buy time and see where how the situation evolved.

With matters in the Cherokee Nation unsettled, Weer decided to stay put at his camp on the Grand River. On his approach to Cherokee Nation in early July, Weer made clear his intention to "make a delay of some days when within striking distance of Tahlequah and Fort Gibson, in order to give the Cherokees a chance to renew their treaty obligations to the Government or be swept out of the country." Although Chief Ross' refusal to treat with Weer 
was unexpected, Weer decided to stick to his original plan and give the Cherokees time and space to settle their internal affairs. ${ }^{292}$

Weer's decision is baffling. While perhaps John Ross needed time to think, that did not preclude Weer from carryout out the goals of the expedition: liberating Indian Territory and returning the refugees home. From his camp on Flat Rock Creek, Weer could have forded the Arkansas River and continued his advance south. In fact, given that almost all of Creek Nation resided south and west of the Arkansas River, Federal occupation south of the Arkansas would be necessary for the thousands of Creek refugees to return home. Although Confederate forces were finally beginning to rouse by early July, defeating the Confederates in the region was always a necessary component to liberating Indian Territory. Moreover, a victory over the meager Rebel forces likely would've hastened Cherokee defections and perhaps made an impression on John Ross. In short, neither of the expedition's goals could be accomplished by waiting in camp along Grand River. Weer's halt proved a faulty, fateful decision that would ultimately cripple the entire expedition, and for the next ten days (from July 8-July 18) the expedition stood still.

While the Indian Expedition rested in the heart of Cherokee Nation and John Ross deliberated his future course of action, the Confederates in Indian Territory finally began to stir. The rousing of Confederate forces proved difficult, in large part due to General Albert Pike. Still ensconced in his "bastion-on-the-Blue," as one historian has described it, Pike repeatedly ignored orders from General Hindman to take the field. Hindman's orders from mid-June requesting Pike to move in the direction of Fort Gibson had been ignored; instead, Pike gave Col. Douglas

${ }^{292}$ William Weer to Thomas Moonlight, July 2, 1862, Official Records 13, 459-460. 
Cooper command of Rebels north of the Canadian River. Pike's failure to take command angered Hindman, as did Pike's lethargy in forwarding troops to Arkansas.

On July 8, just as the Federal Indian Expedition was settling in near Tahlequah, Hindman directly ordered Pike to take command of the Confederate forces around Fort Smith. Instead, Pike angrily resigned. Given the time it would take for his resignation to reach Hindman, Pike slowly set out with his troops towards Fort Smith. By July 15, his troops were at Boggy Depot, barely twenty-five miles from Fort McCulloch. By the end of July, Pike received word that his resignation had been accepted. Instead of returning to Arkansas as a private citizen, however, he instead traveled to Fort Washita in Chickasaw Nation. From there, Pike published and mass printed a scathing address that commiserated on the sad state of affairs in Indian Territory, blamed Van Dorn and Hindman for the Indians' troubles, and generally undermined Confederate authority throughout the region. Pike promised to travel to Richmond personally and address the Indians' poor condition with the Confederacy. ${ }^{293}$

Albert Pike's address was stunning display of arrogance and insubordination. Since Pike's days as negotiator for the Confederacy in 1861, he firmly believed the Confederate Indians could only trust and be led by him. Although Pike may have hoped his address would restore faith in him, the President, and the Confederate cause, it proved immensely short-sighted. He failed to realize that his refusal to leave the Blue River instead opened up Indian Territory for invasion, and the increasing instability within Cherokee Nation owed itself, in part, to his inaction. A long-winded, incompetent commander, Pike's myriad excuses and tribulations nearly

\footnotetext{
${ }^{293}$ Diane Neal and Thomas W. Kremm, Lion of the South: General Thomas C. Hindman (Macon, GA: Mercer University Press, 1993), 126-127.
} 
prevented the Confederacy from mounting any opposition to the Federals' invasion of Indian Territory whatsoever. ${ }^{294}$

Pike’s proclamation spread quickly, eventually reaching Col. Douglas Cooper. "I consider it dangerous," Cooper reported to Hindman, "and have suppressed all copies in my reach." Cooper further thought Pike "partially deranged, and a dangerous person to be at liberty among the Indians.” Albert Pike fled to Texas, an ignominious end for the man primarily responsible for the creation of Confederate-Indian treaties. Pike's litigious, narrow-minded intransigence further meant that his entire force of over 2,000 never challenged the Federal invasion. The task of opposing the Federals instead rested on the shoulders of Col. Douglas Cooper, who once again was expected to secure Indian Territory for the Confederacy. ${ }^{295}$

Placed in command by Albert Pike on June 23, Cooper established his headquarters at Fort Davis on July 7, still expecting Pike to arrive and take command any day. Built in the winter of 1861-1862, Fort Davis consisted of a motley collection of buildings overlooking the Arkansas River's southern bank. From Fort Davis, Cooper could monitor Federal movements across the river, as well as keep an eye on old Fort Gibson, situated a few miles east of Fort Davis on the Arkansas' opposite bank. Thus situated, Cooper mustered a force of several thousand men from various Indian regiments. He also ordered rifle pits to be constructed around Fort Davis.

${ }^{294}$ Walter Brown penned a thorough biography of Albert Pike, and Chapter 31, "Pen-and-Ink Campaigning in the Territory" provides a nice, albeit sympathetic, summation of the Pike-Hindman feud from Pike's perspective. Brown argues that Pike knew of Drew's defection and instability of Cherokee Nation, and that Pike felt he "must do what he could to retain their loyalty and good will. Since their confidence in the Confederacy depended solely on their faith in him, he [Pike] cogently reasoned that to vindicate himself against Van Dorn and Hindman would be also to defend the Confederacy against all blame for what those two officers had done, or failed to do." Brown's argument is unconvincing. Perhaps Pike believed this line of thinking, but it was arrogant (and incorrect) to assume that the Confederate Indians would only serve or trust Pike alone. Further, Pike's never appears to have corrected the contradiction inherit in his own strategy - by adopting the Blue River as his line of defense for Indian Territory, he abandoned most of Indian Territory to the enemy. Pike knew his actions might be perceived as overly-defensive or as abandonment of Indian Territory, yet fortified on the Blue River anyway. Brown, Life of Albert Pike, 409.

295 Douglas Cooper to T.C. Hindman, August 7, 1862, Official Records 13, 977. 
Reverend Henry Buckner, a Confederate sympathizer accompanying Chilly McIntosh's Creek battalion, told his wife "we felt prepared for them and anxiously hoped they would try to cross." Still, facing an enemy force of 7,000, there was little Cooper could do but vigilantly guard the Arkansas River line. The Federals' rapid advance and Pike's immovability left the Confederates unable to challenge the Indian Expedition directly. Reverend Buckner confessed, "They got to us without fighting, and almost without us knowing that they were this side of Kansas. Pike's forces being at Red river, they rather caught us with our breeches down, and in a fix.." ${ }^{296}$

While Douglas Cooper scraped together a force to challenge the enemy, Federal forces finally began stretching their muscle, sending tendrils out into the countryside to ascertain the both the dispositions of the enemy and the Cherokee government. On July 14, several hundred troopers of the Sixth Kansas Cavalry under Major Campbell left the expedition's camps to ascertain the enemy's position. Riding towards Fort Gibson, the Kansans clashed with enemy pickets and drove them for several miles before finally reaching Fort Gibson as evening approached. The small Confederate garrison fled in the face of the Kansan advance, and Campbell was able to occupy Fort Gibson. As Campbell quickly discovered, however, Fort Gibson was a hollow prize. The Confederate force instead occupied Fort Davis, a newly constructed fortification ensconced across the river on the south bank of the Arkansas. Interrogations of locals suggested the Rebels numbered 6,000-7,000 (a gross overestimation). Joined by William Weer and the bulk of the Sixth Kansas overnight, the Kansan troops

${ }^{296}$ Faulk, et. al, eds., Early Military Forts and Posts, 68-72; Henry Buckner to Mollie Buckner, July 23, 1862, Rev. Henry F. Buckner Collection, OHS. Henry Buckner hailed from Kentucky and had been stationed among the Creek Indians since 1848, apparently gaining tribal citizenship. Although not enlisted in the Confederate army, he seems to have accompanied Confederate Creeks during the early years of the war, before finally seeking refuge in Texas by 1864. After the war, he returned to Creek Nation and continued his ministry until his death in 1883 . Buckner assisted in recording and translating the Creek language, including the creation of a Creek-language Bible. Joseph B. Thoburn, A Standard History of Oklahoma, vol. 3 (Chicago: American Historical Society, 1916), 1241; Henry Buckner to Mollie Buckner, July 2, 1862, Rev. Henry Buckner Collection, OHS. 
continued south on July 15, confirming a large Confederate presence at Fort Davis and exchanging shots with pickets across the river. The Kansans' reconnaissance indicated that the Confederates were not planning on giving open battle, instead relying upon fortifications to command the Arkansas River line and the territory south of it. ${ }^{297}$

As Major Campbell and William Weer probed Fort Gibson, another small detachment of the Sixth Kansas descended on the Cherokee capital of Tahlequah, presumably to ascertain the political situation of John Ross and the loyalties of the Cherokee people. Led by Captain Harris Greeno and accompanied by 50 Cherokee Indians, the troopers reached Tahlequah on the night of July 14 and took stock of the situation. Unfortunately, the town lay abandoned; "all had fled several days previous to my arrival." Determined to find out more, Greeno led his troopers to the small village of Park Hill the next morning, where John Ross and many other prominent Cherokee resided. Two hundred Cherokee Indians awaited them, ready to defect and join the Union army. Apparently, their desire to defect stemmed in part from the recent murder of several loyal Cherokee by Stand Watie's Confederates. ${ }^{298}$

For John Ross, the hour of decision had arrived. He could bid for time no longer. Early that morning, before the blue-clad column entered Park Hill, Ross had received a copy of a proclamation from Colonel Douglas Cooper. Cooper declared that all able-bodied Cherokee men between the ages of eighteen and thirty-five should report to Confederate authorities and repel the invader. The Confederacy was calling. Perhaps to discuss Cooper's proclamation, a number of John Ross' family, friends, and confidents — many of whom were officers in John Drew's nearly extinct Cherokee regiment—were present at Ross' home that morning. The timing of

297 “Report of Col. William Weer," July 16, 1862 and "Report of Maj. William T. Campbell," July 14, 1862, Official Records 13, 160-161; Henry Buckner to Mollie Buckner, July 23, 1862, Rev. Henry Buckner Collection, OHS; McMahon., Reluctant Cannoneer, 48.

298 “Report of Capt. Harris Greeno," July 17, 1862, Official Records 13, 161-162. 
Captain Greeno's arrival, then, proved awkward. With the Confederacy demanding Cherokee conscription, while Federal officers waited in his parlor, John Ross wavered. Appraising the situation, Captain Greeno determined "to decide the matter for him [and] I made them all prisoners of war." Ross and his compatriots were then immediately paroled. It was a clever solution to a thorny problem. By arresting and paroling Ross, Greeno provided the Cherokee chief with a legitimate reason to ignore Cooper's proclamation. Still, it was a momentous act. The Cherokee government now submitted to Federal authority, and Ross anxiously appealed to Greeno for United States troops to reestablish order within the Nation. ${ }^{299}$

The arrest and parole of John Ross—essentially, the defection of the Cherokee government to the Union — constituted a major political coup for William Weer and the Indian Expedition. The incessant rumors and reports of the past year were proving true; when the Federal army arrived in force, hundreds of Cherokees defected en masse. To be sure, Stand Watie and other pro-Confederate Cherokees remained in the field. The Federal invasion and Cherokee defections in the summer of 1862 finally split Cherokee Nation asunder, throwing them into intra-tribal civil war.

299 "Report of Capt. Harris Greeno," July 17, 1862, and "Report of William Weer," July 16, 1862, Official Records 13, 160-162; Stephen Foreman diary, July 15 and July 16, 1862, Stephen Foreman Papers, WHC, OU; E.H. Carruth and W.H. Martin to William G. Coffin, July 19, 1862, Annual Report of the Commissioner of Indian Affairs (Washington, D.C.: G.P.O., 1862), 158.

Greeno's account contradicts a popular misconception that the defection of John Ross was planned all along. Instead, it seems Ross was rather indecisive in the moment; only Greeno's assertiveness solved the issue and presented an honorable way for Ross to abandon the Cherokee-Confederate treaty. From his house near Tahlequah, however, pro-Confederate Stephen Foreman thought very differently of the whole episode, lambasting the Cherokee officers of Drew's Confederate for their treachery. "Some of these very persons," Foreman scolded, "made and ratified the [Confederate] Treaty under which they were clothed and fed and paid all last winter, and where are they? Why after lying about [Fort] Gibson and near Chief Ross's spending thousands of dollars for the Confederate Govt., the turn over to the Feds, join the Northern Army, and take the oath to support the Lincoln Government." Foreman similarly believed the Ross was a secret Unionist, whose defection was preplanned. 
Yet while Federal forces finally achieved a key political breakthrough within Cherokee Nation, the logistical and morale situation within the Expedition's camp deteriorated rapidly. When Union soldiers wearily arrived at their camp on the Grand River after the long march south, morale had sunk dangerously low. The sweltering sun was bad enough; the inconsistent access to potable water seemed worse, especially since Union soldiers increasingly believed that Weer's cruelty and incompetence was partly responsible for their suffering. Reflecting on the morale of the men, Ohioan Luman Tenney admitted to his diary, "I feared there would be a mutiny, so many boys hadn’t water and weren’t permitted to leave the ranks to get any."

The Expedition's long stint at the Grand River encampment ensured a steady supply of good water, but inactivity did little to improve morale. Union soldiers could not understand why Weer made his men march "with great rapidity, regardless of the suffering of his men and their increasing debility in this severe climate," only to suddenly halt in the face of the enemy. One soldier groused of "the vicinity of the enemy being sufficient to check [Weer's] movements." Another trooper judged Weer's "bump of combativeness is somewhat small." Largely unaware of the delicate political situation in Indian Territory, the Expedition's soldiers could not grasp why they stood idle. ${ }^{301}$

Further sapping morale was the men's increasingly low opinion of their commander. Weer's proclivity to drink was an open secret around camp, and his seeming indifference to his men's deprivation incensed enlisted and officers alike. One Ohioan recalled that "Col. Weir, on our journey down, was said to be drunk all the time, by his own rum." Major Albert Ellithorpe thought it "a terible [sic] state of affairs, when the lines of any army are placed in the hands of a

\footnotetext{
${ }^{300}$ Tenney, War Diary, 20-21.

301 "From the 2d Ohio Cavalry," Cleveland Morning Leader, August 5, 1862; "Our Military Correspondence. From the Second Ohio Cavalry," Jeffersonian Democrat, August 1, 1862.
} 
worthless drunken officer.” A story ran through camp that Weer had scorned the need for a large supply train, instead chiding that "good soldiers could live on a pint of corn a day, soaked in water, and then use the water to drink." As one trooper mocked, "Col. Weir likes his corn extracted in a different manner." 302

The men's disdain for their commander is evident in one Ohio trooper's description of their commander to a newspaper back home. "I saw the worthy General once, and only once, and the following is a pretty correct sketch of his stylish appearance: He is probably some 5 feet, 8 or 10 inches in height, portly person, sandy, bloated complexion, long, uncombed, sandy hair and whiskers. His costume consisted of a dirty white shirt, hanging half out, and lopping over a pair of dilapidated regulation pants, while a pair of old slippers, down at the heel, completed his wardrobe." 303

The Indian Expedition, then, was plagued by low morale, stemming first from the scorching Southern sun and irregular access to water, followed by days of inactivity in the face of the enemy and growing lack of confidence and discontent with their inebriate commander. Two greater dangers, however, seemingly posed existential threats that pushed the unhappy expeditionary forces into open mutiny.

The first danger from Confederate forces arrived not to the front but supposedly from the rear. William Weer had always been sensitive about the possibility of Confederate raiders

302 "From the 2d Ohio Cavalry," Western Reserve Chronicle, September 10, 1862; Johansson, ed., Albert C. Ellithorpe, 25-26; "Our Military Correspondence. From the Second Ohio Cavalry," Jeffersonian Democrat, August 1, 1862. Although it's unclear whether Weer actually expressed such a sentiment, Weer's reported comments appear in several accounts of the campaign. It was soon reported by the Cleveland Morning Leader back in Ohio that Union soldiers were forced to soak and consume corn and water in this manner, though that does not appear to be the case. Nevertheless, this particular rumor indicates the increasing anger felt by the Expedition's soldiers towards their commander. "From the 2d Ohio Cavalry.-Gross Outrages in the Kansas Department," Cleveland Morning Leader, August 4, 1862. 1862

303 “Our Military Correspondence. From the Second Ohio Cavalry," Jeffersonian Democrat, August 1, 
striking his left flank out of Arkansas and Missouri as he marched south. Sometime in mid-July, this phantom threat seemed to materialize, as Weer "received reliable information that a large force of the enemy were moving to our rear," supposedly in the vicinity of the Verdigris River. It's unclear whether any Confederate force actually threatened the Union rear. Back at Fort Scott, General James Blunt worried that General Hindman in Arkansas might be contemplating a strike into Indian Territory, thus cutting off the Expedition's supply route and avenue of retreat. Blunt wrote to Weer on the subject, advising him to advance with caution. Yet Weer never received Blunt's warnings and had no knowledge of the threat Hindman posed. Hindman himself never made a westward lunge anyways. Confederate Indian forces were known to be operating out of Fort Davis, and Albert Pike's command still occupied a position far to the south. In all probability, there was no Confederate force on the Verdigris River at all. Rumors and false reports spread like wildfire throughout the Civil War, often proving false. It is likely that Weer's intelligence, portending a phantom Confederate force poised to strike at the Expedition's rear, was faulty. Despite the imaginary threat, Weer nevertheless took the reports seriously and at face value. $^{304}$

${ }^{304}$ Frederick Salomon to Indian Expedition, July 18, 1862, Official Records 13, 475-476. On July 14, Blunt wrote a letter to William Weer informing him Weer that Federal forces in northern Arkansas under General Samuel Curtis were moving east towards Memphis, thus leaving Weer's eastern flank along the Arkansas-Territory line unsupported. Blunt worried that Hindman, reported to have 10,000 men, "will endeavor to get in between you and Fort Scott, cutting of your supplies." Blunt cautioned Weer to advance cautiously and retreat at the first sign of an attack by Hindman, as Weer's force was now responsible for protecting Kansas in the face of invasion. Some scholars have incorrectly assumed that Weer received this warning from Blunt, and thus Hindman was what worried Weer. Yet these messages didn't arrive until July 25, days after the mutiny. Unbeknownst to the Federals was that Hindman was in no real position to attack anyway, as he scraped together an army of scattered regiments and conscripts. Frederick Salomon to James Blunt, July 29, 1862, Official Records 13, 521-522.

If any Confederate force actually did threaten the Expedition's rear, it may have been a Missouri State Guard unit. Small forces of pro-Confederate Missouri State Guard, such as those of John Coffee, J.J. Clarkson, and James Rains, lurked along the Arkansas-Missouri-Cherokee Nation lines routinely that summer. It is possible that a Guard unit temporarily moved into Indian Territory, thus prompting the rumors. The author, however, has been unable to find any evidence of a Missouri State Guard unit operating within Cherokee Nation in early-mid July, 1862. James Blunt to William Weer, July 14, 1862, and Frederick Salomon to Indian Expedition, July 18, 1862, Official Records 13, 472, 475-476; William L. Shea, Fields of Blood: The Prairie Grove Campaign (Chapel Hill: University of North Carolina Press, 2009), 4-7. 
The second danger looming over the Expedition was an increasing shortage of food, caused by scarcity of local provisions and a breakdown in supply lines and communication with the Department of Kansas. By mid-July, the Indian Expedition occupied an advance position within Cherokee Nation, encamped on the Grand River over 150 miles south of Fort Scott. The countryside proved incapable of sustaining the Expedition's forces. The landscape lay bare of food or forage, and drought and Confederate arsonists burned the surrounding prairies. With no proper forage, cavalry mounts grazed on ill-nourishing grass. Although Weer thought the Cherokee country "completely conquered," he could barely patrol it, as his horses were malnourished, and slow-moving wagons accompanied every patrol to feed the men. The nearly 1,500 Cherokee defectors to the Union flag all need food and supplies, further straining the Expedition's logistics. Although the Expedition was enduring, its logistical situation was undoubtedly strained. ${ }^{305}$

With little local food available, the Indian Expedition's survival was tethered to its supply train reaching back to Fort Schott Kansas. Given Expedition's considerable distance from its base of operations, combined with the possibility of attacks by Confederate raiders, Weer should have kept in constant communication with his supply train and provided escorts. Unfortunately, during Colonel Weer's rapid advance south, he lost communication with his supply trains. On July 14 , the trains failed to arrive on schedule. Weer had not received any communication from Kansas in nearly two weeks, and he had no idea why the supplies failed to arrive or where they could be found. Several attempts to locate the trains via scouting parties failed. Perhaps Weer began to wonder whether the Confederate force supposedly threatening his rear had something to do with the train's tardiness. In fact, the supply train was just fine, parked 75 miles to the north

${ }^{305}$ William Weer to Thomas Moonlight, July 12, 1862, Official Records 13, 487-488. 
on the Grand River, waiting for a Union escort to guide them to the Expedition's camps. Colonel Weer's failure to manage his supply lines thus imperiled the entire Expedition. By mid-July, the 7,000 man Indian Expedition possessed only three days' rations and faced the prospect of slow starvation. The atmosphere in camp grew tense. ${ }^{306}$

Sensing the magnitude of the strategic and logistical obstacles he faced, though apparently unaware of the mounting morale problems among his men, on July 17, Colonel Weer called together the Expedition's unit commanders in a council of war. The Kansan commander revealed the dire situation to his officers. The supply train was three days overdue, and none of the three couriers sent out to locate the supplies had returned. The expedition only possessed three more days' rations, and the countryside was too barren to provide much sustenance. Twelve days had passed since Weer's last communication with the Department of Kansas. Setting aside the ominous logistical situation, the Arkansas River had swollen and was now impassable; the expedition could not strike against the enemy at Fort Davis. Worse, Weer announced "he had received reliable information that a large force of the enemy were moving to our rear via the Verdigris River for the purpose of cutting off our train." 307

The news landed like a bombshell among the expedition's officers. The council unanimously determined "that our only safety lay in falling back to some point where we could reopen communication and learn the whereabouts of our train and subsistence." William Weer agreed with his officers, promising to write orders of march for a northerly retreat. After the council departed, however, "the decision seemed to enrage him." Weer angrily declared "he

${ }^{306}$ Frederick Salomon to the Indian Expedition, July 18, 1862, and Frederick Salomon to James Blunt, July 20, 1862, Official Records 13, 475-476, 484-485.

${ }^{307}$ Frederick Salomon to the Indian Expedition, July 18, 1862, and Frederick Salomon to James Blunt, July 20, 1862, Official Records 13, 475-476, 484-485; "From the 2d Ohio Cavalry," Cleveland Morning Leader, August 5, 1862; Gardner, "First Kansas Battery," 341. 
would never leave the presence of the enemy, but would see them all in $\mathrm{h}-\mathrm{l}$ first." Reversing course, Weer determined to stay in his present location and ordered the entire expedition placed on half rations. Col. Frederick Salomon desperately appealed for Weer to reconsider, but the Kansan "refused utterly." William Weer had made his decision. ${ }^{308}$

On the evening of July 18, the officers of the expedition gathered in their own private council of war without William Weer. The officers agreed "one course was left for them, and although grave as it was, a unanimous voice said it must be done." The commander of every expedition unit agreed that Weer must be deposed. "As next in command to Colonel Weer, and upon his express refusal to move at all for the salvation of his troops," Colonel Salomon confessed, "I felt the responsibility resting upon me. ${ }^{309}$

Salomon ordered Weer's arrest, and Captain Eckhart of the Ninth Wisconsin detained Weer. While the officers confronted their commander, the soldiers of the expedition were roused. There was some concern that the expedition's Kansas troops, especially Norman Allen's Kansas Battery and Weer's own Tenth Kansas Infantry, would balk at the mutiny underway and back their Kansas colonel. Trooper Isaac Gause of the Second Ohio Cavalry recalled, "Everything in camp was in motion. Some were getting their arms, and some running for the horses. The infantry fell in with fixed bayonets; the batteries loaded with grape and canister, and muzzles turned toward the first brigade." Reluctantly, however, the Kansan soldiers backed down and

${ }^{308}$ Frederick Salomon to the Indian Expedition, July 18, 1862, and Frederick Salomon to James Blunt, July 20, 1862, Official Records 13, 475-476, 484-485; "From the 2d Ohio Cavalry," Cleveland Morning Leader, August $5,1862$.

${ }^{309}$ Frederick Salomon to the Indian Expedition, July 18, 1862, and Frederick Salomon to James Blunt, July 20, 1862, Official Records 13, 475-476, 484-485; "From the 2d Ohio Cavalry," Cleveland Morning Leader, August 5,1862 . 
acquiesced to the mutiny. The First Indian Expedition now rested in the hands of Colonel Frederick Salomon. ${ }^{310}$

Having taken command, Colonel Salomon issued a proclamation to expedition's commanders explaining his actions. The document likely reflected Salomon's understanding of the gravity of his actions, and his desire to clearly identify his reasons for usurping William Weer. "In military as well as civil affairs great and violent wrongs need speedy and certain remedies," Salomon began. "Some one must act, and that at once, or starvation and capture were the imminent hazards that looked us in the face." The Wisconsin colonel recounted the reasons for the necessity of the mutiny: the long, fatiguing marches south, the "putrid, stinking water" forced on the men, the disregard of William Weer for his men, the lack of communication with Kansas, the lost supply train, and the dwindling food stores. "I have stood with arms folded and seen my men faint and fall away from me like the leaves of autumn," Salomon lamented, “because I thought myself powerless to save them." Salomon ended his proclamation by assuming responsibility for the affair and asking for the men's patience and support. ${ }^{311}$

Salomon hardly needed to ask for the backing of the expedition's enlisted men. In a letter home, one Ohio soldier admitted, "The whole command was in ecstacies [sic] over the deposing of the old vagabond, and Colonel Salomon was the delight and admiration of both officers and soldiers.” In his diary, Luman Tenney summed it up nicely: “All were glad.” Major Hermann Schlueter recorded similar sentiments, with one significant caveat, "All in good spirits again,

310 "Interesting Letter from the Ninth Wisconsin Regiment," Quiner Scrapbooks, Vol. 8, 58-59, WHS; Gause, Four Years with Five Armies, 95-96; Tenney, War Diary, 21-22; Johansson, ed., Albert Ellithorpe, 33-34. Major Albert Ellithorpe reported in his diary, "Great excitement prevails for Were [sic] has many friends, \& is a Kansas man, while Salomon is a foreigner \& from another state. The Kansas men think it an assumption of power that will discredit the Kansas troops."

${ }^{311}$ Frederick Salomon to the Indian Expedition, July 18, 1862, Official Records 13, 475-476. 
except Col. Weir and 10 Kansas." Although the Kansans submitted to the mutiny, some

remained unhappy with the embarrassing turn of events. ${ }^{312}$

The mutiny of the First Indian Expedition originated from a peculiar source. Unlike most Civil War mutinies, the revolt emanated first not with enlisted volunteers but instead among the expedition's officers. The July 17 council of war looms large in the narrative of events. Had Weer submitted to the council's unanimous decision to retreat, the crisis may have been avoided. But Weer's final refusal to defer to the council sealed his fate. Officers deemed one of their peers dangerously incompetent and agreed to remove him. ${ }^{313}$

While officers provided the first mutinous spark, however, the soldiers of the expedition proved willing to stoke the flame. Support from the expedition's enlisted ranks was vital to the success of the whole affair. For the takeover to succeed, William Weer needed to be arrested, dissenting Kansans needed to be quelled, and soldiers needed to be willing to submit to Colonel Salomon's authority. All of these things came to pass because the men of the expedition willed it. Enduring extraordinary heat, unclean water, and limited provisions, the Expedition's soldiers suffered. Yet soldiers expected harsh conditions in field service. It was William Weer's callous, inebriated, incompetence that made soldiers' suffering needless. In this aspect, the mutiny reflected a prevailing sense of soldiers' rights held by many volunteers. Forced to endure heat, lack of water, harsh discipline, a drunken commander, and finally ten days of inactivity along the Grand River, the expedition's enlisted ranks believed that Colonel William Weer violated their basic rights as soldiers. Once Weer violated this social contract, soldiers no longer felt bound to

312 "From the 2d Ohio Cavalry," Cleveland Morning Leader, August 5, 1862; Tenney, War Diary, 21; Hermann Schlueter diary, BCAS.

313 Thaddeus Michael Romansky, "Disunion in the Ranks: Soldiers, Citizenship, and Mutiny in the Union Army" (PhD dissertation, Texas A\&M University, 2015). Romansky's dissertation, "the first scholarly study of mutiny in the Union Army," provides a slew of case studies of mutiny in the Union Army throughout the war, almost all of which originated in the ranks. Romanksy, "Disunion in the Ranks," 6. 
respect his martial authority. Thus, when Weer was arrested by Salomon, most of the

expedition's soldiers were "in ecstacies." 314

Having assumed command of the Indian Expedition, Col. Salomon wasted no time in taking action. At 2 o'clock on the morning of July 19, Union soldiers abandoned their camp on the Grand River and began retreating north. Salomon left behind the three Indian Home Guard regiments "as a corps of observation" to hold the countryside north of the Arkansas River, while the main expedition retreated north to reestablish communication with the supply train and Kansas. $^{315}$

Throughout the entire mutiny, the Indian Home Guard regiments slept soundly in their own camps nearby. Unaware of the dramatic turn of events, they awoke early on the morning of July $19^{\text {th }}$ to the unpleasant discovery that they were alone, with "but meager verbal and indefinite orders or instructions from Colonel Salomon." The commanders of the Indian units, "finding themselves in the condition in which they were left and confusion among the rank and file of their respective regiments," agreed to coordinate and operate as a brigade, with Colonel Robert Furnas of Nebraska as the overall commander. Despite the officers' attempts to established order, the sudden retreat of the bulk of the Indian Expedition unsurprisingly demoralized Native American soldiers, and bouts of desertion afflicted the Indian regiments over the coming days. ${ }^{316}$

\footnotetext{
${ }^{314}$ Romanksy, "Disunion in the Ranks," 11. Romanksy notes that "association, localism, print culture, and popular constitutionalism together made for a rich matrix that nourished soldiers rigths claimed by diverse groups of Union volunteers in varying degrees and contrasting ways while in uniform." Romansky devotes much attention to the role of ethnicity in shaping mutinies. It's perhaps worth remembering here that the First Indian Expedition contained white Anglo-Americans, ethnic German immigrants, and Native American soldiers. While the German Ninth Wisconsin sometimes provoked a competitive spirit with their fellow Kansans, there is very little evidence of any ethnic or racial tension during the expedition, nor during the final mutiny. Although some Kansans seemed to have been disgruntled with Weer's arrest, one Ohioan noted, "the movement met the approval of both foreign [nonKansan] and State [Kansas] troops." "From the 2d Ohio Cavalry," Cleveland Morning Leader, August 5, 1862.

315 Frederick Salomon, “General Orders No. 1," July 18, 1862, R.W. Furnas, "General Orders No. 1,” July 19, 1862, Frederick Salomon to James Blunt, July 20, 1862, and R.W. Furnas to James Blunt, July 25, 1862, Official Records 13, 476-477, 481, 484-485, 511-512; Tenney, War Diary, 21.

${ }^{316}$ R. W. Furnas to James Blunt, July 25, 1862, Official Records 13, 511-512.
} 
The retreat of the Indian Expedition didn't just worry natives in the Federal ranks, but likewise provoked consternation and fear among Unionist Indians and refugees generally. Indian Agents Edwin Carruth and H. Martin wrote to General Blunt, "We beg of you in behalf of the Cherokee Nation, especially that portion of it, whites and Indians, who have for months slept in thickets and cane, to do something speedily to arrest the desolation that will follow the shameful retreat of our army." The agents prophesied that if the Federal retreat continued, "the families of the men who have flocked to the Union standard will be ruthlessly murdered." "They ought to have, they deserve," the agents thundered, "protection, and we humbly pray that you will extend such help as speedily as possible." If the Union again abandoned Indian Territory, Unionist Indians - both refugees who accompanied the expedition south and those who emerged from hiding upon its arrival—would be vulnerable..$^{317}$

The July 18 mutiny sparked a precipitous retreat northward, but it didn't quite end the Indian Expedition. Instead, over the next few weeks Colonel Salomon tried to retain Union influence over Cherokee Nation north of the Arkansas River, while simultaneously keeping most of the expedition's forces posted on the Kansas line. It was a half-in, half-out approach that couldn't accomplish what the expedition intended.

On July 19, the long-lost supply train was located at Hudson's Crossing on the Grand River. Colonel Salomon elected to station the expedition near that location, believing it offered strategic and logistical value, particularly "ample grazing and good water." One can sense Salomon's careful accounting of environmental factors when selecting his campsite, dubbed "Camp Quapaw.” The camp was only a few miles from the Kansas state line. Salomon

${ }^{317}$ E.H. Carruth and H.W. Martin to James Blunt, July 19, 1862, Official Records 13, 478. 
studiously avoided Weer's mistakes and established clear lines of communication and supply stretching from Kansas to Camp Quapaw and down the Indian brigade's observation post along the Arkansas River. Union patrols scoured the countryside. "Tahlequah, Fort Gibson, the upper crossings of the Arkansas, and other points of importance" were occupied, and the expedition's health and morale improved. Although Colonel Salomon worried about the possibility of a strike on his flank out of Arkansas or Missouri, all seemed well. From his advanced position with the Indian Brigade along the Arkansas River, Colonel Furnas stated "we can hold our present position, and keep the enemy on the other side of the Arkansas, we have no doubt." 318 Colonel Furnas' declaration proved hasty. While Furnas' Indian “corps of observation” was strong enough to occupy Cherokee Nation, its advanced position left it dangerously exposed to Cooper's Confederates. Colonel Salomon's force, now 70-80 miles north, was out of supporting distance. By late-July, Douglas Cooper grew increasingly confident and ordered several Rebel regiments to probe north of the Arkansas River, including Stand Watie's $2^{\text {nd }}$ Cherokee Mounted Rifles, who quickly struck out for Park Hill "intending to punish John Ross and the Union people of that vicinity." Watie's forces, however, were intercepted at Bayou Bernard, a crossroads just seven miles east of Fort Gibson, on July 27 by Union Indians under Major William Phillips. A sharp clash ensued, and Watie's Cherokees were driven back with

${ }^{318}$ Frederick Salomon to James Blunt, July 29, 1862, Official Records 13, 521-522. Salomon essentially established a string of positions, running from Kansas to the Arkansas River, from which to control the countryside. Three detachments were posted along the route from Hudson's Crossing to Furna's position near the Arkansas River, named "Camp Wattles" and located on Horse Creek. Salomon sent patrols to guard the countryside (though patrol admittedly struggled due to the horses' haggard condition), and garrisons occupied key locations. Patrols also watched for the possibility of General T.C. Hindman's Confederates lashing out from the east out of Arkansas. General Blunt, in communication with Salomon, ordered the colonel to cooperate with Union forces in Missouri to keep the expedition's eastern flank secure. "Our present position," Salomon declared, "gives us all the backbone required to occupy a country and be timely prepared to meet the enemy." All in all, Salomon seems to have effectively controlled the countryside and maintained mobility and security for several weeks in ways Weer did not. Frederick Salomon to James Blunt, July 29, 1862, and James Blunt to Frederick Salomon, August 3, 1862, E.B. Brown to Frederick Salomon, August 5, 1862, Official Records 13, 521-522, 531-532, 539-540. 
considerable cost. Although a Federal victory, the fight at Bayou Bernard indicated that Cooper was increasingly restless and aggressive. As Indian Agents Carruth and Martin confessed, "Times were getting dangerous; the enemy...having got knowledge of the retreat of our white troops." Stretched thin by occupation duties and Rebel raids, and soon facing food shortages of his own, Furnas' command fell back towards the Kansas line. ${ }^{319}$

Although Colonel Frederick Salomon's actions in the wake of the July 18 mutiny perhaps saved the expedition from dire logistic and strategic straits along the Grand River, his retreat north weakened the Union's hold on northern Indian Territory and left the major Confederate force in the region intact. Holding the region north of the Arkansas River was not enough to allow many of the refugees to return home. In short, the mutiny and Salomon's retreat ensured that the First Indian Expedition would accomplish neither of its two goals: Federal authority was not reasserted over the Five Tribes, nor could the majority of the Indian refugees return home.

While Cooper's raids in late July forced the retreat of the Indian Brigade under Colonel Furnas, newly-promoted Brigadier General Salomon learned that the murky Confederate threat to the east, long a cause of anxiety for Weer and Salomon alike, finally materialized. By late July, ominous reports of large concentrations of guerrillas in Arkansas began circulating among Federal commanders in Missouri. In early August, these disparate Confederate commands burst forth not into Indian Territory, but instead into southwest Missouri. Meager Union forces in the region were overwhelmed, and several Union garrisons and towns were swallowed up by the sudden invasion. The early August uprising in Missouri ended any possibility of the Indian Expedition marching back south to challenge General Cooper's Confederates. The expedition

${ }^{319}$ Reports of Major William A. Phillips, July 27 and August 6, 1862, Official Records 13, 181-183; E.H. Carruth and H.W. Martin to William G. Coffin, August 2, 1862, Annual Report of the Superintendent of Indian Affairs, 162-164. 
constituted the largest Union force in the region, and in a choice between Indian Territory or Kansas and Missouri, Federal authorities made their preferences clear. Fort Scott must be defended, and the Confederates driven back. With a crisis brewing, Colonel Salomon marched much of the expedition's forces back to Fort Scott in early August. The remainder of the expedition soon followed suit. By the end of August, not a single Federal soldier occupied Indian Territory; once again, the Union abandoned Indian Territory. ${ }^{320}$

Looking back over their expeditionary travails of the past month, many frustrated Union soldiers believed their time in Indian Territory had been pointless. "As you perhaps already know, the 'Grand Indian Expedition' has proved a failure," opined one Ohio trooper, "no good whatever being accomplished, and the whole thing being but an immense expense from which the Government derived no possible benefit." Many espoused the idea that the whole expedition existed simply "for the caprices of Kansas politicians, and the whims of Kansas contractors." Private William Wildman angrily declared, “Kansas may go to thunder, for all I care, they can't talk 'Bleeding Kansas to me.' I have had enough of it." ${ }^{\text {,321 }}$

While enlisted soldiers harped on the expedition's seemingly superfluous nature, the importance of the expedition and the real costs of its failure were evident in the thousands of Union Indians whose lives were disastrously and, with the expedition's failure, meaninglessly uprooted. For the hundreds of Union refugees who accompanied the expedition south expecting to return home and plant crops, the expedition's failure meant another winter spent shivering in

${ }^{320}$ John Schofield to J.C. Kelton, July 26, 1862, Official Records 13, 513-514; Richard Brownlee, Gray Ghosts of the Confederacy: Guerrilla Warfare in the West, 1861-1865 (1958; repr., Baton Rouge: Louisiana State University Press, 1985), 76-79, 92-97; Matt Matthews and Kip Lundberg, "Shot All to Pieces: The Battle of Lone Jack, Missouri, August 16, 1862," North and South vol. 7, no. 1 (January, 2004): 58-60; Frederick Salomon to James Blunt, August 9, 1862, and Thomas Moonlight, "General Orders No. 4," Official Records 13, 551-552, 595.

321 "The Condition of the Second Cavalry," Cleveland Morning Leader, September 2, 1862; "From the 2d Ohio Cavalry," Cleveland Morning Leader, August 5, 1862; "From the 2d Cavalry," Western Reserve Chronicle, August 20, 1862. 
Kansas refugee camps. For the thousands of Unionist Indians who emerged from hiding upon the expedition's approach, they faced reprisals or the prospect of becoming refugees themselves.

Given the intense heat and accompanying drought that summer, many Indians left their homes in search of food. On July 25, Indian Agents Carruth and Martin reported from Cherokee Nation that, "even now, while I write, women and children, with every imaginable means of conveyance, are passing the house on their way to find the protection and bread their own country cannot give." In the wake of the Union army's retreat, faced with prospect of Confederate reprisals and withering crops, nearly 1,500 fresh Cherokee refugees accompanied the expedition back into Kansas. Not only did the Indian Expedition fail to permanently liberate Indian Territory or return the refugees to their homes, it actually exacerbated the refugee crisis back in Kansas. ${ }^{322}$

From its outset, the First Indian Expedition faced severe environmental and leadership obstacles that ultimately undermined its ability to accomplish its objectives. Its tardy launch in early July, the product of political wrangling and continual leadership changes, gave the expedition only a tight window in which to accomplish its objectives of securing Indian Territory for the Union and allowing refugees to return home in time to plant crops for the winter. In their rapid advance south, Union soldiers endured long marches under extraordinary heat, while simultaneously suffering from a lack of clean water. While Colonel William Weer couldn’t control the sun, he could control the pace of march and where his forces encamped. His carelessness in regard to both speaks to poor leadership in the face of a harsh environment; his men suffered for it, and morale sank.

\footnotetext{
${ }^{322}$ E.H. Carruth and H.W. Martin to William G. Coffin, July 25, 1862 and September 28, 1862, Annual Report of the Commissioner of Indian Affairs, 160-161, 167.
} 
The Indian Expedition's rapid advance is all the more baffling given Weer's long encampment on the Grand River in the face of the enemy. Had Weer advanced promptly across the Arkansas River and defeated the much smaller Confederate force stationed at Fort Davis, the expedition would have gone a long way towards driving the Confederates from the Territory. Such an advance would have also opened up Creek and Seminole Nations for liberation, from whence most of the native refugees hailed. A decisive victory over Rebel forces likely would've driven even more Cherokees into the Union fold, and perhaps hastened John Ross' defection. Instead, Weer lingered for ten days along the Grand River, having lost communication with his supply lines and allowing the Arkansas River to rise to impassible heights. Perhaps Weer's welldocumented intemperate habits (even in the face of battle!) addled his decision-making process. Regardless, all of these factors: the harsh environment, lack of water, sinking morale, inactivity in the face of the enemy, Weer's inebriation, and a deteriorating supply situation resulted in mutiny.

The July 18 mutiny and subsequent retreat north marked the turning point for the expedition. Although the Union command remained in Indian Territory for several more weeks under Colonel Salomon's leadership, the retreat of the expedition's forces nearly to Kansas weakened the Federals' hold over Indian Territory and indicated that the Confederate presence south of the Arkansas River would go unchallenged. Colonel Cooper's increasing belligerence in late July and the guerrilla uprising in southwest Missouri in August were merely the final blows to the Indian Expedition, forcing Union troops to finally abandon Indian Territory yet again. Thus, Union authorities needed to repeat the whole process in 1863; once again mounting another expedition meant to liberate Indian Territory and return the refugees to their homes. 


\section{"The Indians Are Not Cared For":}

\section{Cabin Creek, Honey Springs, and the Failure of the Confederate-Indian Alliances}

"All believe that one fact develops itself, and that is, that the Indians are not cared for, and that the Confederate States are throwing them off to shift for themselves as best they can, contrary to the Treaty which provides protection and pledges itself to keep out all intruders."

- Cherokee Reverend Stephen Foreman, August 12, $1863^{323}$

Colonel Thomas Bass stood by the riverbank and wept. A private moment of anguish, the tearful colonel of the $20^{\text {th }}$ Texas Cavalry was discovered by David Dumas, a nineteen year old private of the $5^{\text {th }}$ Texas Partisan Rangers. The two men's regiments had stood together in the maelstrom of battle the day before. Breaking the colonel's solitude, David inquired as to what was wrong. "David," the colonel replied, "I have lost nearly all my brave boys and I feel as if my heart will break. I had to see them fall like dead leaves from a tree without any support to offer them." Struck by the colonel's emotion, Private Dumas “joined in the weeping, for among the dead were many I had known and loved." So the thirty-three year old colonel and nineteen year old private cried together on the banks of the Canadian River. It was July 18, 1863, and the day previous the Texans and their Indian allies fought and lost the Battle of Honey Springs. ${ }^{324}$

The largest battle fought in Indian Territory during the Civil War, the Battle of Honey Springs marked the crescendo of the Union's second invasion of Indian Territory, a military venture which fared far better than its ill-fated predecessor. Weathering Confederate attempts to oust them from the Territory, Federal forces garnered decisive victories at Cabin Creek and Honey Springs that offered the Union permanent, if at times tenuous, control of Indian Territory north of the Arkansas River. In the weeks following the engagements, blue-clad soldiers

323 Stephen Foreman diary, August 12, 1863, Stephen Foreman Papers, WHC, OU.

${ }^{324}$ David E. Dumas, "War Notes as Remembered by David Elhanon Dumas," 5 ${ }^{\text {th }}$ Texas Partisan Rangers File, Hill College Historical Research Center, Hillsboro, TX (hereinafter referred to as HCHRC); Mamie Yeary, ed. Reminiscences of the Boys in Gray, vol. 1, (Dallas, TX: Smith \& Lamar, 1912), 351. 
penetrated south of the Arkansas River into Choctaw Nations for the first time, resulting in the fall of Fort Smith, Arkansas. By the autumn of 1863, the strategic situation in Indian Territory and the wider Trans-Mississippi shifted permanently in favor of the Union.

Certainly the Federals played a decisive role in liberating northern Indian Territory that summer. The bold, aggressive leadership of Union General James Blunt and his subordinates Colonels William Phillips and William Cloud stands in stark contrast to the mediocre generalship of Douglas Cooper and William Steele. Union soldiers, including whites, Native Americans, and African-American, displayed great bravery and combat effectiveness in the field. Refusing to repeat the mistakes of the summer previous, the Federals devoted much time and energy to keeping their supply lines open, ensuring Union soldiers were well-armed, well-fed, and amply supplied.

Yet the greatest determinant in Confederate defeats at Cabin Creek, Honey Springs, and elsewhere was the inability and unwillingness of the Confederate States to fulfill its treaty obligations to their Indian allies. Indian and Texan troops in the Territory suffered from a lack of small arms, artillery, ammunition, clothing, equipment, wagons and the other sundry but vital materials necessary to waging war. Arkansan reinforcements sent to the Territory's defense proved worthless: under-strength, demoralized, and ill-disciplined. The failure of the Confederacy to uphold its treaty obligations stemmed not only from the serious material shortages that plagued the Trans-Mississippi Department, but also from the racial prejudices of white Confederates who increasingly viewed their Indian allies as militarily and racially inferior. Despondent at a string of defeats and increasingly convinced the Confederacy had abandoned them, Confederate Indians determined to rely upon each other in hopes of saving their respective nations from Union occupation. 
Although the Confederacy worked hard to pull the Five Tribes into Confederate orbit in 1861, they ultimately failed to fulfill those alliances, failures that came to bitter fruition in 1863 . While Confederate leaders may have dreamed of a sprawling slave empire whose tendrils stretched deep into the Trans-Mississippi, including control of Indian Territory, in reality shortages of arms, ammunition, supplies, and manpower and racial prejudice meant that the Confederacy routinely prioritized the security of the Confederacy they had-Arkansas, Texas, Missouri-over the Confederacy of their dreams. The results proved disastrous for Indian Territory.

The Confederate resurgence of the previous August — the same uprising that forced the Indian Expedition to retreat to Kansas_-grew to even more dangerous proportions in September. General Hindman, desperate to scrape together an army with which to challenge Union control of northwestern Arkansas and southwestern Missouri, ordered various Confederate officers to ride into Missouri and fill their ranks with fresh recruits. After minor victories at Lone Jack and Independence in August, Rebel ranks swelled. With the Federal presence in Indian Territory gone, General Hindman ordered Douglas Cooper to take his Indian Brigade along with a newly arrived Texas cavalry into southwestern Missouri to join the growing Confederate presence there. General Blunt's forces in Kansas were likewise drawn to the region, including brigades under the disgraced yet still commanding Colonel William Weer and freshly-promoted Brigadier General Frederick Salomon. Somewhat ironically, the long-expected clash that never emerged in Indian Territory in July now arrived in southwestern Missouri in September. ${ }^{325}$

${ }^{325}$ Larry Wood, The Two Civil War Battles of Newtonia (2010; repr., Charleston, SC: History Press, 2013), 39-53. Wood's book offers probably the most in-depth exploration of both the 1862 Battle of Newtonia. Although he provides a bibliography, he does not offer footnotes however, making it difficult to trace his sources. 
On September 30, 1862, a small Federal detachment reconnoitered in the direction of Newtonia, Missouri. Discovering the town occupied by a similarly-sized Confederate garrison, the Federal troops attacked the town. For nearly the next ten hours, what began as a simple scouting expedition mushroomed into a substantial, see-saw battle involving approximately 4,500 Federals and 5,000-6,000 Confederates. After initial early morning clashes, General Cooper arrived to take command in person, bringing along his own First Choctaw and Chickasaw Mounted Rifles led by Lieutenant Colonel Tandy Walker. The Choctaws and Chickasaws looked forward to the fray, "singing their war-songs and giving the war-whoop"; they faced their first serious taste of combat since fighting Opothleyahola at Chustenahlah nearly a year prior. The Rebel Indians were ready and made a dashing charge on the Union flank and "put them to flight." Confederate fortunes continued to prevail, and by noon the Southerners firmly held the field. ${ }^{326}$

Yet the fight was far from over. General Salomon soon arrived on the field, and throughout the afternoon battle was again joined. More Native American soldiers on both sides faced the elephant for the first time and were given chances to prove themselves on the field of battle. Around four o'clock, the haggard troopers of the First Choctaw Regiment under Col. Sampson Folsom arrived on the after a thirty-five mile ride that morning. Folsom's Choctaws swooped down on the Federal line, supported by Walker's Choctaws and Chickasaws. Their foe during the ensuing clash was none other than the Third Indian Home Guard, Colonel William Phillips commanding. Native Americans in both blue and gray battled each other as the sun sank in the sky. Watching the battle unfold in front of him, Douglas Cooper admitted, "The booming of cannon, the bursting of shells, the rattling crash of small arms, the cheering of our men, and

\footnotetext{
${ }^{326}$ Wood, Civil War Battles of Newtonia, 59-90; Report of Col. Douglas Cooper, October 2, 1862 Official Records, vol. 13, 296-300.
} 
the war-whoop of our Indian allies, all combined to render the scene both grand and terrific." After a full day's fight, the outnumbered Federals retreated, leaving the Confederates in command of the battlefield and Douglas Cooper with perhaps his finest victory of the war. The Battle of Newtonia earned laurels for both Union and Confederate Native American troops. Frederick Salomon praised the conduct of the Third Indian Home Guard; Douglas Cooper likewise complimented his command for their "bravery and coolness" and paid particular thanks to Lt. Col. Tandy Walker. The Rebel victory, however, proved hollow. Reinforcements under Generals Blunt and Schofield arrived in the vicinity of Newtonia within a week, forcing the Rebels to slink back to Arkansas and abandon their Missouri foothold. ${ }^{327}$

Both Blunt and Schofield proved anxious to pursue the fleeing foe. They marched into Northwestern Arkansas in mid-October, camping near the old Pea Ridge battlefield. At this time, Union forces in the region were reorganized into the Army of the Frontier under General Schofield. General Blunt assumed command of the First Division (often called the "Kansas Division”), comprised of three brigades under Brig. Gen. Frederick Salomon, Col. William Weer, and Col. William F. Cloud. The division contained many veterans of the First Indian Expedition, including all three Indian Home Guard regiments. Blunt and Schofield agreed to pursue the enemy, and Blunt's division was tasked with tracking down the Rebel contingent under Col. Douglas Cooper which had disappeared back into Indian Territory. On October 20,

${ }^{327}$ Wood, Civil War Battles of Newtonia, 77-98; Reports Brig. General Frederick Salomon, October 1, 1862, and Col. Douglas Cooper, October 2, 1862, Official Records, vol. 13, 286-288, 296-300. General Salomon also took a moment to thank William Weer "for his conduct before, during, and after the battle." Several other notable regiments fought at Newtonia, including the Ninth Wisconsin Infantry, Sixth Kansas Cavalry, and a Confederate Cherokee Battalion under Major J.M. Bryan. 
Blunt led his forces towards the Arkansas-Territory line in pursuit of the Confederates and within two days closed with his enemy. ${ }^{328}$

The Confederates under Douglas Cooper were encamped just inside Cherokee Nation on Beattie's Prairie near Old Fort Wayne, a long-abandoned military post hailing from the 1830s. Cooper had been given orders to assemble his Indians for a raid into Kansas, a questionable endeavor that if executed would likely have left Cooper in danger of being cut off from Indian Territory. Delays in gathering his troops, however, hindered the proposed expedition, and Cooper's command only mustered some 1,500 men, including Col. Sampson Folsom's First Choctaw and Chickasaw Rifles, Col. Stand Watie's First Cherokee Rifles, Col. Daniel McIntosh's First Creek Regiment, and Lt. Col. Chilly McIntosh's Creek battalion. Also present was an invaluable wagon train containing over 10,000 pounds of gunpowder. ${ }^{329}$

Although James Blunt commanded far more men than his Confederate counterpart as he approached Beattie's Prairie on the morning of October 22, his dogged pursuit of the enemy and poor management caused much of his command to fall behind. Indeed, less than 600 men of the Second Kansas Cavalry accompanied Blunt as he advanced on the enemy's camp. Undeterred by his force's size, confident in the impending arrival of reinforcements, and aggressive by nature, Blunt attacked Cooper anyway. As one officer admired, Blunt's decision was in "the most approved Western style.” Hoping to pin the Confederates in place, Blunt ordered the Second Kansas Cavalry to dismount and, supported by two mountain howitzers of the First Kansas Battery, the Jayhawkers engaged the enemy in a sharp firefight at two hundred yards. Although

${ }^{328}$ James L. McDonough, Schofield: Union General in the Civil War and Reconstruction (Tallahassee: Florida State University Press,1972), 38; William L. Shea, Fields of Blood: The Prairie Grove Campaign (Chapel Hill: University of North Carolina Press, 2009), 35.

${ }^{329}$ Reports of Brig. Gen. Douglas Cooper, October 25 and December 15, 1862, Official Reports, vol. 13, 331-336; Odie Faulk, et al, eds., Early Military Forts, 48, 72-73, Shea, Fields of Blood, 38-39. 
the Confederates' numbers soon threatened the Federal flanks, the timely arrival of the Sixth Kansas Cavalry and Third Indian Home Guard bolstered the Union line. ${ }^{330}$

As the momentum began to shift, Captain Samuel Crawford led several hundred troopers of twin Kansas regiments forward in a "gallant charge, driving in [the Confederate] center, capturing their artillery, and bringing it in triumph from the field." As the Rebels reeled from the stunning assault, more Federal units arrived and the Rebels beat a hasty retreat. Stand Watie's Cherokees and Daniel McIntosh's Creeks performed a smart rearguard action, fending off the Sixth Kansas and Third Indian in a running seven-mile fight that ended only when Union horses began to give out. Although the Rebels managed to escape the battlefield with their baggage train intact, they left behind a captured three-gun battery and their pride on the field at Beattie's Prairie. The Union suffered five killed and five wounded; the Confederates reported three killed, twenty-five wounded, and thirty-five missing. ${ }^{331}$

The skirmish at Old Fort Wayne was an embarrassing debacle for Cooper and the Confederacy. Despite enjoying superior numbers and a defensive position, Cooper's forces nevertheless broke in the face of a smaller, yet more determined foe. Given how precious artillery was for Confederate commanders in Indian Territory throughout the war, the loss of

\footnotetext{
${ }^{330}$ Reports of Brig. Gen. James Blunt, October 22 and October 28, 1862, Official Records, vol. 13, 325328; Report of Lt. Col. Owen Bassett, October 24, 1862, Official Records, vol. 13, 329-331; Shea, Fields of Blood, 35-39. Johansson, ed., Albert C. Ellithorpe, 54. William Shea's chapter "Return to Arkansas" in Fields of Blood offers an excellent, in-depth account of the Battle of Old Fort Wayne, which is also sometimes labeled Beattie/Beattie's Prairie or Maysville (named after a small Arkansas village several miles away).

${ }^{331}$ Reports of Brig. Gen. James Blunt, October 22 and October 28, 1862, Official Records, vol. 13, 325328; Reports of Brig. Gen. Douglas Cooper, October 25 and December 15, 1862, Official Reports, vol. 13, 331-336; Return of Casualties at Old Fort Wayne, Ind. T., October 22, 1862, Official Records, vol. 13, 336; Shea, Fields of Blood, 35-43; John Howard Kitts, "The Civil War Diary of John Howard Kitts," Collections of the Kansas State Historical Society, 1915-1918, vol. 14, edited by William Connelley (Topeka: Kansas State Printing Plant, 1918), 323-324. In his after action report, Cooper again showed a penchant for inflating numbers, as he had after previous engagements. He pegged the Federals' strength at 5,000; barely one-tenth of that number were arrayed against him. He also placed enemy casualties "from 75 to 100." How Cooper could even estimate the enemy's losses since he was driven from the field is hard to say. Blunt likewise exaggerated the affair, claiming the Confederates numbered nearly 5-6,000 and lost 150 killed and wounded.
} 
three guns was disastrous. Even worse was the sinking morale of Confederate Indians, who felt “abandoned by their white brethren." As with Pea Ridge in March, once again the Confederacy ignored their treaties with the Five Tribes and had called them to service outside of Indian Territory. Although Douglas Cooper and the Confederate Indians turned in a solid performance at Newtonia, their victory was quickly marred by the defeat at Old Fort Wayne. While white forces retreated further into Arkansas towards Van Buren and Fort Smith, Cooper took his battered Indian command, destitute of clothing and demoralized, all the way back to Fort Davis on the south-side of the Arkansas River. In doing so, they left Cherokee Nation north of Indian Territory open for Federal invasion. ${ }^{332}$

By the end of October, the Confederate threat on Missouri had dissipated. General Cooper's force retreated deep into Indian Territory, and General Hindman's armygrandiloquently styled the First Corps of the Army of the Trans-Mississippi-withdrew behind the shield of the Boston Mountains. Although Schofield and Blunt briefly contemplated allowing Blunt's Kansas Division to reoccupy Indian Territory and allow the Indian troops "to re-establish themselves and their families," the proposal was deemed too risky given that Hindman's army still lurked in western Arkansas. Thus, everything seemed to settle down for the winter and Schofield moved back into Missouri with the bulk of the Army of the Frontier. James Blunt's Kansas Division remained in Northwest Arkansas to secure the Union's presence in the area and keep a watchful eye on the Boston Mountains to the south. ${ }^{333}$

Blunt nevertheless kept an interest in Indian Territory. In late October, he sent Colonel William Phillips, commander of the Third Indian Home Guard and a rising star after strong

${ }^{332}$ Report of Col. Douglas H. Cooper, October 25, 1862, James Blunt to John Schofield, October 26, 1862, Official Records, vol. 13, 331-332, 765.

${ }^{333}$ John Schofield to Samuel Curtis, October 24, 1862, John Schofield to James Blunt, October 25, 1862, Official Records, vol. 13, 759-760, 763-764; Shea, Fields of Blood, 50-51. 
performances at Bayou Menard and Newtonia, on a reconnaissance patrol into Indian Territory. Phillips's small command ventured all the way to Fort Gibson and back. Their findings seemed fruitful. Indian faith in the Confederacy was sputtering, and yet more Native recruits bolstered the Federal ranks. "Everything looks favorable in the Indian Territory if our advantages are followed up," Blunt optimistically reported. "It is all-important to occupy the Indian country as far south as the Arkansas River.” Despite his position in Arkansas, James Blunt seems never to have forgotten the failure of the First Indian Expedition, or the debt of the Federal government to restore order and return the Loyal Indians to their homes. ${ }^{334}$

Just as the Confederacy violated their agreements in calling their Indian allies to service beyond Indian Territory's bounds, the Indian Home Guards likewise grew restless at their posts within the Army of the Frontier. Unsurprisingly, discipline eroded as Indians slipped away from their regiments to visit their families in the refugee camps in Kansas or to scout around Indian Territory. Major Albert Ellithorpe blamed Opothleyahola for interfering with army affairs. "Opothlesholan [sic] in his policy to distract the Indian Soldier from his obedience to the commands of the Government is unquestionably rendering to the enemy the most signal aid." Ellithorpe wrote to Creek leaders around Leroy asking that "every man who was enlisted as a soldier shall at once return to his command." These issues were reflective of mounting Indian frustrations. For over a year, Unionist Indians received endless promises of the liberation of their country, and three full Indian Home Guard regiments were raised and equipped for the purpose. Yet the First Indian Expedition proved a failure, and the Indian Home Guard was protecting Arkansas. Although Blunt, Schofield, and others remained aware of the need to liberate Indian

${ }^{334}$ James Blunt to John Schofield, October 24, 1862 and November 9, 1862, Official Records, vol. 13, 760761, 785-786; Johansson, ed., Albert C. Ellithorpe, 48. 
Territory, Native Americans were learning that other priorities in Missouri and Arkansas came first. ${ }^{335}$

The Federals' assumption that winter brought a halt to campaigning proved incorrect. In fact, Schofield's withdrawal of most of the Army of the Frontier left James Blunt's Kansas Division dangerously exposed in Northwest Arkansas. Although warned about his precarious position, Blunt nevertheless decided to remain in region, another questionably bold decision in a string of questionably bold decisions that were becoming the hallmark of Blunt's campaign style. Realizing that a Federal division lay isolated to his north, Thomas Hindman sensed an opportunity and struck. In November, a division of Confederate cavalry led by Gen. John Marmaduke left the security of the Boston Mountains and scouted north towards Cane Hill. Marmaduke opined to Hindman that "I believe you can capture this force, if you can move secretly and with celerity." Marmaduke's reports further convinced Hindman that the time was ripe to undertake a winter offensive. General Hindman's plan called for Marmaduke's cavalry to keep Blunt's attention to the south, while the three divisions of Hindman's First Corps swung around the flank of the unsuspecting Kansas Division and struck from the rear. ${ }^{336}$

The Rebels' offensive went awry almost immediately. Rather than allowing Marmaduke to pin his division in place, Blunt attacked Marmaduke's cavalry at Cane Hill on November 24. In a sharp engagement, the Kansas Division-including the Indian Home Guard regimentsdecisively defeated Marmaduke's cavalry. The clash at Cane Hill shaped the campaign is several important ways. First, in taking the offensive, the Blunt's division was pulled even further south — more isolated than ever. Second, Marmaduke's repulse should've been a red flag to Hindman, an indication both of Blunt's aggression and Marmaduke's inability to keep the enemy

\footnotetext{
335 Johansson, ed., Albert C. Ellithorpe, 47-48, 50-51.

${ }^{336}$ Marmaduke quoted in Shea, Fields of Blood, 91.
} 
pinned in place. Finally, after Cane Hill, Blunt grew wary of the possibility of further Confederate attack, eventually calling on the division of Francis Herron to hurry south from Missouri to join the Kansas Division.

Despite the defeat at Cane Hill, Hindman stuck to his plans and marched northward in hopes of outflanking Blunt. Although Hindman successfully outmaneuvered his foe, he also learned that Herron's division was approaching from the north. Effectively positioned in between two Union divisions with three of his own, Hindman made a final commitment to battle. The aggressive Southerner hoped to defeat the enemy in detail, electing to strike at Herron's division first and then turning to finish off the trapped Kansas Division to the south. On December 7, Hindman's Confederate Army of the Trans-Mississippi attacked Francis Herron's division of the Army of the Frontier at Prairie Grove. Hearing cannons' roar to his north, Blunt's Kansas Division quickly marched to the sound of the guns, hoping to arrive in time to unite with Herron's men and defeat the enemy. Desperate, deadly frontal assaults by Hindman and Herron at Prairie Grove failed to dislodge either foe; such a stalemate inherently benefitted the Federals, for with every passing moment, Blunt's division inched nearer.

In the afternoon, the much-looked-for Kansas Division arrived and linked up with Herron's battered division. Once again, the Federals and Confederates exchanged heavy blows. Included in the fierce afternoon fighting was the First Indian Home Guard, who performed well under heavy fire during a front assault against the Confederate flank. As the sun set, the tired blue and gray clad lines eyed each other warily across the fields of Prairie Grove. After a day of brutal fighting, the Federals suffered approximately 1,251 casualties compared to 1,483 Confederates; neither side had gained an appreciable tactical advantage. Faced with a tactical stalemate, the Confederates' inability to defeat the enemy in detail left General Hindman no 
choice but to retreat south. The Battle of Prairie Grove shattered Confederate designs on Missouri, opened Arkansas for invasion once again, and left the Army of the Frontier free to take the field south in the spring. ${ }^{337}$

Collectively, the battles of Newtonia, Old Fort Wayne, and Prairie Grove influenced both the course of the war in the Trans-Mississippi and provided invaluable combat experience to many Native American regiments and their commanders. The Confederate defeat at Prairie Grove permanently shifted the war south and paved the way for a second expedition into Indian Territory. Both the Federal Indian Home Guard and Confederate Indian Brigade saw meaningful combat during the campaigns; the Indian Home Guard garnered laurels, while their Confederate counterparts turned in mixed-performances. For Douglas Cooper, these autumn clashes offered both a well-earned victory at Newtonia and an embarrassing defeat at Old Fort Wayne. James Blunt's victories at Old Fort Wayne and especially Prairie Grove marked him as an aggressive, confident commander on the rise. These two men and their Native American commands would soon clash again in the summer of 1863.

In early January, 1863, forty-four year old Brigadier General William Steele arrived in Fort Smith, Arkansas. Possessing a slender face with heavy mustaches, Steele enjoyed an admirable pedigree that suggested he could succeed in the struggling Department of Indian Territory. A West Point graduate and Mexican War veteran, Steele commanded the $7^{\text {th }}$ Texas Cavalry during the ill-fated New Mexico Campaign in the spring of 1862, followed by a stint of service in the Western Theater and promotion to brigadier general. With the tumultuous ouster of Albert Pike from command of the Department of Indian Territory in the summer of 1862, Steele

${ }^{337}$ Shea, Fields of Blood, 261. 
was tapped to replace Pike and assumed command of the department in January. Despite being warned by General Hindman of the "exhausted condition of the country," Steele was nevertheless dismayed by the "gloomy" demoralization and destitution of his new command. Over the next few months, Steele worked to overcome the logistical, morale, and manpower difficulties faced by his command. The destitution of the Confederate Department of Indian Territory in 1863 underscores the inability of the Confederacy to fulfill its material promises to the Five Tribes and its prioritization of nearby Confederate regions over Indian Territory. ${ }^{338}$

On paper, Steele commanded nearly a division of Confederate soldiers. Colonel Douglas Cooper's Indian Brigade reportedly contained 6,000 men, occupying Fort Davis and the Arkansas River line. Two regiments of Confederate cavalry, the First Arkansas Cavalry (Monroe's) and the First Texas Partisan Rangers, reported to Steele from Fort Smith. Also attached to the department was a brigade of dismounted Texas cavalry and infantry under the command of Col. Joseph Speight. In reality, these regiments were riddled with sickness, low morale, and a lack of supplies. The Arkansas and Texas regiments in Fort Smith could only muster 150 men fit for duty combined. Cooper's Indians were bereft of supplies and increasingly faithless in the Confederacy after the disaster at Old Fort Wayne. The Texas brigade also suffered from a lack of supplies, regular desertion, and harbored considerable anger over having been dismounted prior to the Battle of Prairie Grove. ${ }^{339}$

${ }^{338}$ Ezra J. Warner, Generals in Gray: Lives of Confederate Commanders (1959, repr., Baton Rouge: Louisiana State University Press, 1994), 41-42; "Report of Brig. Gen. William Steele,” February 15, 1864, Official Records vol. 22:1, pgs. 28-36.

339 "Report of Brig. Gen. William Steele," February 15, 1864, Official Records vol. 22:1, pgs. 28-36; Ralph A. Wooster, Lone Star Regiments in Gray (Fort Worth, TX: Eakin Press, 2002), 247-252, 279-281; Alywn Barr, Polignac's Texas Brigade (College Station: Texas A\&M University Press, 1998), 1-8. Speight's brigade was comprised of the $22^{\text {nd }}$ Texas Cavalry (Col. Robert Taylor), $31^{\text {st }}$ Texas Cavalry (Col. Trezevant Hawpe), $34^{\text {th }}$ Texas Cavalry (Col. Almerine Alexander), and the Fifteenth Texas Infantry (Col. Joseph W. Speight). Also attached to the brigade for a time was the $20^{\text {th }}$ Texas Cavalry (Thomas Bass). The $29^{\text {th }}, 22^{\text {nd }}, 31^{\text {st }}$, and $34^{\text {th }}$ Texas Cavalry regiments hailed primarily from northern and eastern Texas, including many counties that had opposed secession. Rumors swirled that many of the Texans harbored Unionist sentiments. Some of the Texans believed they were only to be 
If the department's manpower was deceptive, the logistical situation proved absolutely dire. The various commands under William Steele lacked uniforms, arms, ammunition, and wagons. Douglas Cooper reported his Indian troops were "almost destitute of clothing; miserably equipped in all respects; poorly armed (many of them without arms)." Private Dallas Bowman, a trooper in Cooper's $1^{\text {st }}$ Choctaw and Chickasaw Mounted Rifles, admitted to his uncle that "Our horses have all died up from starvation... What few horses we have left was sent off to Fort Washitaw, where they can get corn for them." The First Texas Partisan Rangers possessed "not a change of clothing nor an average of a blanket to the man." Soldiers toted firearms either obsolete or in disrepair. The Territory's quartermaster and commissary departments were "were found in the utmost confusion." Desperate to improve the situation, Steele established workshops to repair wagons and guns. Steele also placed "repeated requisitions" for arms and ammunitions, pleas answered only by silence. Taking matters into his own hands, Steele sent officers down into Texas to secure arms and ammunition and managed to secure 500 guns and a supply of ammunition from San Antonio. These guns, procured only through Steele's own initiative, were "the only arms brought into the Territory" in 1863-Steele, Indian Territory, and its Native American denizens were left to fend for themselves. ${ }^{340}$

The complete lack of provisions and forage proved to be the most critical logistical shortfall, one that made General Steele's orders nearly impossible to carry out. Upon taking command of Indian Territory, Steele was tasked by General Hindman with holding the "line of the Arkansas River." Yet months of campaigning in 1862 combined with mounting banditry and

used in defense of North Texas and the Red River Valley, and indeed the regiments had organized and spent time in southern Indian Territory in the spring of 1862 under General Albert Pike. In the fall of 1862, however, they moved to the front and participated in the fights at Newtonia and Prairie Grove.

340 "Report of Brig. Gen. William Steele," February 15, 1864, Official Records vol. 22:1, pgs. 28-36. Dallas Bowman to uncle, January 26, 1863, Dallas W. Bowman Collection, OHS. 
guerrilla activity left Indian Territory bereft of provisions; there was simply not enough food and forage to sustain large numbers of Confederate soldiers. The destitution of the countryside forced Steele to disperse his army. The 1st Arkansas Cavalry was ordered to pester the Union army in Northwest Arkansas. The $20^{\text {th }}$ Texas Cavalry remained in Fort Smith on garrison duty. Cooper's Indians held the Arkansas line at Fort Davis, but Cooper allowed large numbers of his Indian troopers to return home on furlough, a policy born of both a lack of discipline and the necessity of keeping the troops fed. Finally, the Colonel Speight's brigade of dismounted Texas cavalry and infantry was ordered to winter in the Red River Valley along the Territory-Texas line, where provisions could be had. Steele hoped that this dispersion of his forces would allow him to build up supply depots for a spring campaign. Still, the Territory's barren condition left Confederate troops scattered across the region, and Steele worried that he would not be able to quickly gather his forces and march once warmer weather arrived. ${ }^{341}$

Perhaps the only solace for the Confederacy and Steele was that the countryside's destitution likewise prevented the Federal army from concentrating in any significant numbers north of the Arkansas River within the Territory. Instead, Cherokee Nation north of the Arkansas became a relative no-man's-land. Army patrols, irregular companies of Pin Indians, and bandits crisscrossed and plagued the landscape and those few denizens who clung to their homesteads, but presented no serious threat to the Confederacy's control over southern Indian Territory. ${ }^{342}$ As spring approached, the strategic situation transformed as the prospect of renewed campaigning loomed. In April, a small force under Colonel William Phillips carried out General

341 "Report of Brig. Gen. William Steele," February 15, 1864, Official Records vol. 22:1, pgs. 28-36. Even provisions along the Red River were sparse. James Carr wrote to his sister, "Times is hard here. We draw a little poor beef to eat. We take it with out salt." Robert S. Weddle, Plow-Horse Cavalry: The Caney Creek Boys of the Thirty-Fourth Texas (Austin, TX: Madrona Press, 1974), 89.

342 "Report of Brig. Gen. William Steele," February 15, 1864, Official Records vol. 22:1, pgs. 28-36. 
Blunt's orders to reoccupy Indian Territory north of the Arkansas. On the morning of April 25, after an overnight march of thirty miles, Col. Phillips made his presence known by striking Stand Watie's regiment near Webber's Falls. The attack caught the Confederate Cherokees off-guard, and Watie's men fled after suffering several casualties. The skirmish at Webber's Falls not only embarrassed Watie, but offered the bonus of preventing the Confederate Cherokee Legislature from meeting in the town that day. Having announced the return of Federal forces to the region, Colonel Phillips settled into Fort Gibson and set to work fortifying the post. "I do not think the enemy can menace me with a heavy force for two or three weeks yet," Phillips confidently reported. "It would be ruinous to the Government cause, as well to these people, to abandon the country," Phillips continued. "I shall maintain my ground at all hazards." 343

The return of the Federal army to Indian Territory in April arrived at an inopportune moment for General Steele, as his meager command was being further stripped by Confederate authorities in other departments. Hoping to unify his scattered forces, Steele ordered Col. Speight's Texas brigade along the Red River to march north. After just a few days' march, however, Steele learned that Speight's brigade had been reassigned to Louisiana. "Notwithstanding this sudden and important depletion of my effective strength," Steele resolved to try and drive the enemy from Fort Gibson before his foe grew more entrenched or was reinforced. $^{344}$

Across six weeks from late May until the first of July, William Steele and William Phillips conducted a complicated game of cat and mouse across the rolling prairies and woods of

${ }^{343}$ James Blunt, "General Blunt's Account of His Civil War Experiences," Kansas Historical Quarterly, 1, no. 3 (May, 1932), 239; Reports of Col. William A. Phillips, April 26 and undated, 1863, Official Records, vol. 22:1, 314-315.

344 "Report of Brig. Gen. William Steele," February 15, 1864, Official Records vol. 22:1, pgs. 28-36; Weddle, Plow-Horse Cavalry, 89-90. 
northern Cherokee Nation. General Steele played the cat, working to oust the enemy from his fortified nest at Fort Gibson by striking at his supply trains. If Steele could use his superior numbers to starve the garrison into submission, Fort Gibson and Cherokee Nation could be retaken at minimal cost. Colonel Phillips played the mouse, mustering all his meager strength to desperately fend off enemy attacks and keep the supply lines to Fort Scott open. Both sides waged the campaign with alacrity and skill, and a series of sharp skirmishes climaxed in the First Battle of Cabin Creek on July 1, 1863.

The Confederacy's offensive kicked off in late May. A slim brigade of Confederate cavalry, including Cherokees, Creeks, and the old Arkansas-Missouri guerrillas under John Coffee, splashed across the Arkansas River on the night of May 19. An unwatchful scout failed to spot the Rebels, and by daylight on May $20^{\text {th }}$ the Confederates were within a few miles of the fort. Constant construction under the observant eye of Colonel Phillips had turned Fort Gibson into something of a miniature Gibraltar on the Arkansas, and the Confederates wisely elected not to attack the post directly. Instead, they set about trying to round up and capture the immense herd of livestock that ranged freely about the fort.

Recognizing the loss of the herd endangered his post as much as the enemy, Colonel Phillips scrounged together "all the mounted men I could raise" and sent them forth to secure the livestock. The advancing Federal troops clashed with the Southern counterparts in a series of sharp firefights five miles from the fort's earthworks. Twin parties of the $6^{\text {th }}$ Kansas Cavalry and $3^{\text {rd }}$ Indian Home Guard were both "nearly surrounded...but they gallantly cut their way through." As the fighting picked up, Colonel Phillips personally sallied forth with a mixed force of Indian infantry and artillery and "drove the enemy" from the field. Rebel resistance weakened then snapped, and the Confederates fled back across the safety of the Arkansas. Though Phillips 
hoped to pursue, a Rebel feint near Fort Gibson upriver forced the Federals to peel off and return to their post. The "severe" clash at Fort Gibson resulted in approximately 26 Federal casualties; Confederate casualties are unknown but likely higher. Though an incomplete victory, most of the cattle herd was recovered, and a supply train arrived the day after the fight. Colonel Phillips and Fort Gibson survived its first test. ${ }^{345}$

Over the next few weeks, the Confederates kept up the pressure on beleaguered Federal post. Pickets exchanged shots across the Arkansas, occasionally punctuated by grander Confederate cannonades. On May $28^{\text {th }}$, the Rebels once again slipped north of the Arkansas and struck at a Union supply train but were rebuffed in a small skirmish and forced to retreat. In early June, Stand Watie led a larger Confederate raid across the Arkansas in hopes of striking at Union troops encamped at Baxter Springs just inside the Kansas line. Colonel Phillips was again ready to react, but due to jaded horses could only move once he knew the precise location of the Rebels. After confirming the Confederates had passed through Tahlequah, Phillips ordered Maj. John Foreman of the $3^{\text {rd }}$ Indian Home Guard in pursuit. The Rebel raid was foiled not by Union pursuers, however, but by the high waters of the Grand River. Unable to cross, Watie led his men south while Foreman's Union Indians nipped at his heels. Meanwhile, Colonel Phillips, who continued to oversee affairs from Fort Gibson, dispatched Col. Stephen Wattles of the $1^{\text {st }}$ Indian Home Guard with 400 men to cut of Watie's avenue of retreat. If all went well, the Rebel raiders would be trapped between Foreman's and Wattle's columns. ${ }^{346}$

On June $16^{\text {th }}$, Col. Wattles caught up to Watie's command at Greenleaf Prairie north of the Arkansas River. Watie's Cherokees had been reinforced in the night by Tandy Walker's First

345 “Report of Col. William A. Phillips," May 22, 1863, Official Records vol. 22:1, 337-338.

346 "Report of Maj. Gen. James G. Blunt," June 8, 1862, and "Report of Col. William A. Phillips," June 20, 1863, Official Records vol. 22:1, pg. 341-342, 348-350. 
Choctaw and the $29^{\text {th }}$ Texas Cavalry, and Watie's command was prepared to fight their way through the Federals to make good their escape. Wattles gamely engaged the enemy in a see-saw fight of several hours, but as ammunition ran low, Wattles disengaged in hopes of being reinforced by Maj. Foreman's column. Foreman's haggard horses, however, had given out earlier in the day. Upon learning the news, Wattles began to retreat. A relief column of 500 men arrived to bolster Wattles' force, but the break in hostilities offered Stand Watie a window through which to slip away. The Cherokee raider re-crossed to the south side of the Arkansas on June $17^{\text {th }}$, having barely escaped Col. Phillips' neatly-prepared trap. ${ }^{347}$

Colonel Phillips's heroic efforts in keeping the supply lines open and repulsing Rebel raiders throughout May and June did not go unnoticed. General Blunt placed great confidence in Colonel Phillips and praised the "superhuman efforts to hold the country to the Arkansas River." Acknowledging the "hard pressed" situation at Fort Gibson and fearing another withdrawal from the Indian Territory would be "disastrous," Blunt organized a relief column to assist the besieged defenders of Fort Gibson. The "endurance of hardships and privations, as well as their display of patriotism and gallantry, entitle them to be promptly supported," and by late June two eclectic regiments and one artillery battery waited at Baxter Springs to be sent south to the front. ${ }^{348}$

347 "Report of Col. William A. Phillips," June 20, 1863, and "Report of Col. Stephen H. Wattles," June - , 1863, Official Records vol. 22:1, 348-352;"Report of Maj. J.A. Carroll," June 20, 1863, The Standard [Clarksville, TX], July 4, 1863; "Report of Col. Charles DeMorse," June 21, 1863, The Standard, July 18, 1863. The Official Records only contain reports for Col. Stephen Wattles, $1^{\text {st }}$ Indian Home Guard, and Col. William Phillips for "Operations about Fort Gibson, Ind. T., including skirmish $\left(16^{\text {th }}\right)$ at Greenleaf Prairie." Yet the Clarksville Standard, a North Texas newspaper founded and edited by Col. Charles DeMorse of the $29^{\text {th }}$ Texas Cavalry, contained the reports of both Maj. Carroll and Col. DeMorse for the Greenleaf fight. Their reports add significant detail and depth in understanding the engagement. Col. DeMorse indicated Federal casualties at: 28 killed, 29 wounded, and 6 captured (63 total; a significantly higher figure than given by the Federals); DeMorse puts Confederate casualties at: 8 killed, 8 wounded, and 4 captured (20 total, similar to Union reports).

${ }^{348}$ Maj. Gen. James G. Blunt to Col. William A Phillips, May 30, 1862, Official Records vol. 22:2, 297298; “Report of Maj. Gen. James G. Blunt,” June 8, 1862, Official Records, vol. 22:1, 341-342. 
The $1^{\text {st }}$ Kansas Colored Infantry comprised the heart of the relief column. One of the earliest African-American regiments raised for Union service, the origins of the $1^{\text {st }}$ Kansas Colored rested with none other than Senator James Lane, the great advocate for enlistment of Native American and African-American troops alike. Comprised of free blacks and runaway slaves from throughout the region (including a number from Indian Territory), the $1^{\text {st }}$ Kansas was commanded by Col. James M. Williams, an ardent abolitionist, a Kansan, and a friend of James Lane (Williams was yet another veteran of "Lane's Brigade" early in the war, alongside James Blunt, William Weer, and others). In October of 1862, the $1^{\text {st }}$ Kansas Colored became the first African-American regiment of the Civil War to see combat, repulsing Confederate guerrillas in a small skirmish at Island Mound, Kansas. By the summer of 1863 , the veterans of the $1^{\text {st }}$ Kansas were again ready to face their foes. Alongside the $1^{\text {st }}$ Kansas Colored were six companies of the $2^{\text {nd }}$ Colorado Infantry. Comprised of "hardy miners, inured to toil and privations, with but little experience in the art of war," the "Pike's Peakers" were soon to see combat for the first time. Finally, a section of the $2^{\text {nd }}$ Kansas Battery rounded out the Federal column. ${ }^{349}$

News of the planned relief column quickly reached General William Steele. Indeed, so well-appraised were the Confederates of the supply train's whereabouts that trooper Wiley Britton of the $6^{\text {th }}$ Kansas complained from Fort Gibson, "Our hostile neighbors across the river seem to be better informed of the movements of our train and troops in the country than we are."

349 “Report of Maj. Gen. James G. Blunt,” June 8, 1862, Official Records, vol. 22:1, 341-342; Robert W. Lull, Civil War General and Indian Fighter: James M. Williams, Leader of the $1^{\text {st }}$ Kansas Colored Volunteer Infantry and the $8^{\text {th }}$ U.S. Cavalry (Denton: University of North Texas Press, 2013), 27-60; Ian M. Spurgeon, Soldiers in the Army of Freedom: The $1^{\text {st }}$ Kansas Colored, the Civil War's First African American Combat Unit (Norman: University of Oklahoma Press, 2014), 48-105; “Compendium of History," Soldier's Letter. Second Colorado Cavalry [Kansas City, MO], 1864. Ian M. Spurgeon's Soldiers in the Army of Freedom offers a fine regimental history of the $1^{\text {st }}$ Kansas Colored Infantry. Robert W. Lull's Civil War General and Indian Fighter: James Williams provides a solid history of the regiment's commander, including his post-war service in the $8^{\text {th }}$ U.S. Cavalry. The Soldier's Letter was a late-war regimental newspaper of the $2^{\text {nd }}$ Colorado Infantry (re-designated the $2^{\text {nd }}$ Colorado Cavalry). 
With the supply train and reinforcements on the way, nearly six weeks of raiding reached a crescendo. If the reinforcements managed to reach Fort Gibson from Baxter Springs, Colonel Phillips' force would likely be too strong to drive from the countryside. If the Confederacy hoped to retain any chance of reclaiming Cherokee Nation, it needed to prevent the junction of these twin Union forces and starve Fort Gibson into submission. ${ }^{350}$

Hoping to intercept the 200-wagon supply train, William Steele organized a two-pronged raid north in late June. The western prong consisted of Colonel Stand Watie's Cherokees, who crossed Arkansas River and moved northward west of Grand River. Reinforcements from Col. Cooper were sent along in support to provide reinforcement. Colonel Cabell's decrepit Arkansans constituted the eastern prong; Cabell's men struck out from Northwestern Arkansas to unite with Watie. General Steele felt confident that if the two forces could combine, they would capture the enemy train. ${ }^{351}$

On June 25, the Federal supply train departed Baxter Springs and headed down into Indian Territory, accompanied by nearly one thousand blue-clad Federal reinforcements. Although the train was stopped by high water along the Neosho River for several days, it managed to cross on the $29^{\text {th }}$ and continued southwest of the Grand River. On June 30, the train's escort picked up the first signs of trouble when they uncovered a recently-made trail. A patrol of twenty Cherokees from the $3^{\text {rd }}$ Indian Home Guard tracked the path four miles before stumbling into an advance picket post of Stand Watie's command. The Federal Cherokees attacked the

${ }^{350}$ William Steele to Douglas H. Cooper, May 24, 1863, Official Records, vol. 22:2, 847; Wiley Britton, Memoirs of the Rebellion on the Border, 1863 (1882, repr., Lincoln: University of Nebraska Press, 1993), 302-303.

351 Wiliam Steele to William Cabell, June 16, 1863, William Steele to Douglas Cooper, June 29, 1863, B.G. Duval [Steele's adjutant] to William Cabell, June 29, 1863, B.G. Duval to Douglas Cooper, June 29, 1863, and William Steele to W.B. Blair, July 1, 1863.Official Records, vol. 22:2, 874, 894-985, 902. 
Confederate Cherokees and routed their surprised foe, killing four and taking three prisoners.

The skirmish alerted the Federals to the enemy's nearby presence. ${ }^{352}$

On July 1, the train continued south until it arrived at Cabin Creek, a 60-yard wide stream swollen from recent rains. The east-west creek and its ford were guarded by Stand Watie's command, consisting of Watie's $2^{\text {nd }}$ Cherokee, Daniel McIntosh's $1^{\text {st }}$ Creek, and several companies of Texan cavalry, numbering approximately 1,400. Watie stood alone, however; neither Cooper's reinforcements nor Cabell's Arkansans-stymied along the east bank of the flooded Grand River - arrived in time. Still, the Confederates enjoyed a significant numerical advantage, although they possessed no artillery. ${ }^{353}$

Leading the Union vanguard was Major John Foreman of the Third Indian. Having skirmished with Watie a month prior and unwilling to be stopped by Watie's men before him, Foreman advanced with his Indians and three mountain howitzers towards the enemy, who were ensconced amid the brush on the south side of the creek "so thick a man could not be seen." The Indian forces opened up a "brisk fire" upon each other across Cabin Creek. The $1^{\text {st }}$ Kansas Colored Infantry and a lone 12-pound gun soon came up in support, led by Captain Ethan Earle. The Federal artillery boomed and "scattered the [Confederate] Indians to the prairie back of the bluff." 354

352 "Report of Maj. John A. Foreman," July 5, 1863, Official Records, vol. 22:1, 382.

353 "Report of Col. James M. Williams," July-, 1863, Official Records, vol. 22:1, 379-381; Capt. Ethan Earle account book, R. Stanton Avery Special Collections Department, New England Historic Genealogical Society, Boston, MA (hereinafter referred to as NEHGS); William Steele to W.B. Blair, July 3, 1863 and July 5, 1863, Official Records, vol. 22:2, 903, 905; Asa S. Morgan to wife, July 7, 1863, Asa Morgan Collection, Arkansas History Commission, Little Rock, AR (hereinafter referred to as AHC). Cooper's and Cabell's inability to connect with Watie caused the critical artillery deficit. The only artillery in Indian Territory was a battery of mountain howitzers under Col. Cooper, for which there was little ammunition. Col. Cabell brought from Arkansas three iron six-pound guns, likewise low on ammunition. William Steele to W.B. Blair, July 1, 1863, Official Records, vol. 22:2, 902.

354 "Report of Col. James M. Williams," July—, 1863, and "Report of Maj. John A. Foreman,” July 5, 1863, Official Records, vol. 22:1, 379-382; Captain Ethan Earle account book, NEHGS. 
The Texans, however, endured the bombardment. On the other side of Cabin Creek, Private John Howard of the $5^{\text {th }}$ Texas Partisan Rangers listened as the Yankees swabbed their guns and weathered the storm of grape and canister. "It hardly looks like twenty men could stand there under fire as we did," Howard remembered, "but every one had a tree and if it had not been for that we could not have lived." Indeed, Captain Earle complained he could only spot a Rebel "when a shot from our cannon cut down a tree or the brush so as to expose them." Eventually, the firefight wore down. The "raging and foaming" waters of Cabin Creek were too high for a crossing, anyway. Though the fighting ceased, neither side retreated, and indeed, throughout the night the Federals brought up the remainder of the reinforcement column and prepared to make a second attack the next day. Watch was kept on the creek's depth, which slowly receded throughout the night. ${ }^{355}$

On the morning of July 2, the Federals resumed their offensive to drive Stand Watie from Cabin Creek and clear the way south. In overall command was Col. James Williams of the $1^{\text {st }}$ Kansas Colored, who devised the "column of attack" that would charge across Cabin Creek and push the enemy back. Consisting of a company of Indians led by Major Foreman, the entire $1^{\text {st }}$ Kansas Colored Infantry, a battalion of the $2^{\text {nd }}$ Colorado Infantry, and several companies of cavalry, the attack column would also enjoy extensive artillery support from five artillery pieces situation broadly across their rear. At 8 a.m., Union guns unleashed a "brisk cannonade, with shell and canister, upon the enemy's position," a bombardment that lasted for forty minutes.

355 "Report of Col. James M. Williams," July—, 1863, and "Report of Maj. John A. Foreman,” July 5, 1863, Official Records, vol. 22:1, 379-382; Yeary, ed. Reminiscences of the Boys in Gray 1, 351; Captain Ethan Earle account book, NEHGS; Britton, Memoirs of the Rebellion, 318. Howard's recollections of Cabin Creek are a bit muddled - he seems to combine details from the engagements at Cabin Creek and Honey Springs together in his account. It's clear the bulk of the recollection deals with Cabin Creek, including the quote used above, although perhaps Howard's memory of intense artillery fire actually hailed from the second day's fighting. 
Having thoroughly shelled the opposite creek bank, William believed the enemy had retreated and ordered the attack column forward. ${ }^{356}$

With Major Foreman at the attack column's head, the first Indians began splashing across Cabin Creek, only to be "met by a violent fire of musketry from the enemy," who remained hidden along the southern bank. Major Foreman suffered two wounds, his horse another five, and the attack floundered as "their gallant leader" fell. Seeing Foreman fall, Colonel Williams promptly intervened. He pulled the Indians back out of the creek and lined the infantry companies up along the creek's north bank. Again opening up heavy musketry and artillery fire, Williams hoped another twenty minute fusillade would silence the enemy. A second crossing attempt was made, this time with black Kansan infantry and a company of the $9^{\text {th }}$ Kansas Cavalry under Lieutenant Philbrick leading the way. The second attack worked. Blue-clad cavalry darted across the creek, followed by stolid infantry, who despite "wading to the arm-pits in water," successfully "pushed the enemy up the bluff to the prairie." Watie's forlorn troopers fell back to the edge of a prairie about 400 yards from the creek and reformed. ${ }^{357}$

Determined to pursue their foes, Colonel Williams' force crossed the creek and formed into line of battle to meet their Rebel foes. While the Federals maneuvered into position, Lieutenant Philbrick's Kansans pushed ahead, ordered by Williams to probe the enemy line. Philbrick's Kansans did more than that. Thundering across the prairie in a "gallantly executed" charge, the Kansans broke the enemy's center and "put him to flight.” Although Philbrick's unlikely charge may have spurred the Rebel retreat, Watie's men were also falling short of ammunition and were perhaps discouraged by the failure of either Cooper or Cabell to appear.

356 "Report of Col. James M. Williams," July—, 1863, and "Report of Maj. John A. Foreman,” July 5, 1863, Official Records, vol. 22:1, 379-382

357 "Report of Col. James M. Williams," July—, 1863, and "Report of Maj. John A. Foreman," July 5, 1863, Official Records, vol. 22:1, 379-382; Captain Ethan Earle account book, NEHGS. 
Regardless, the haggard Confederate command fled, pursued for several miles by the Federals, who ultimately gave up the chase for fear of leaving the supply train unattended. Rumors flew among the Union ranks that Stand Watie personally swam the Grand River alongside several of his men to make good his escape. The First Battle of Cabin Creek inflicted 3 killed and 30 wounded on the Federals; the Confederates lost perhaps as many as 50 dead and wounded, along with nine taken prisoner. ${ }^{358}$

The Battle of First Cabin Creek marked the final opportunity for General William Steele and the Confederacy to starve the Union garrison at Fort Gibson into submission. As Colonel Asa Morgan, commander of the $30^{\text {th }}$ Arkansas Infantry in Cabell's Brigade, admitted to his wife a few days after the battle, "Its [the supply train] capture would have ruined them at Gibson...if Genl Steel did not feel himself strong enough to attack them before he cannot think of it now they are reinforced." Although General Steele did in fact think of attacking again, hopefully with reinforcements from Texas, in reality the Confederacy had no more men to give. The Federals at Fort Gibson, growing hungry on half-rations and anxiously awaiting word of the train's fate to their north, were thrilled at its arrival on July $5 .{ }^{359}$

The fight at Cabin Creek also continued to validate the use of both Native American and African-American soldiers in the Union army. The Indian Home Guard proved instrumental in tracking down the enemy and spearheading the advance across Cabin Creek. The $1^{\text {st }}$ Kansas Colored Infantry provided the heart of the attack column and earned the praise of Col. Phillips at

358 "Report of Col. James M. Williams," July—, 1863, and "Report of Maj. John A. Foreman," July 5, 1863, Official Records, vol. 22:1, 379-382; Captain Ethan Earle account book, NEHGS. After the battle, Wiley Britton at Fort Gibson placed the Federal casualties at 8 killed (several died from wounds), 23 wounded, and 8 missing, mostly from the Indian Home Guard and $1^{\text {st }}$ Kansas Colored Infantry. He estimated the Rebel casualties to be "upwards of a hundred." Britton, Memoirs of the Rebellion, 327.

${ }^{359}$ Asa Morgan to wife, July 7, 1863, Asa Morgan Collection, AHC; William Steele to W.R. Boggs, July 7, 1863 and William Steele to S.P. Bankhead, July 11, 1863, Official Records, vol. 22:2, 909-911, 921-922; Britton, Memoirs of the Rebellion, 307, 326. 
Fort Gibson for having "fought well." Trooper Wiley Britton of the $6^{\text {th }}$ Kansas reveled in the thought that "men who once delighted to ply the lash to the back of colored men were now extremely anxious to get out of these same colored men as quickly as possible." Britton further considered the implications of black and white fighting together, hailing it as "a grand step in the direction of wiping out the idea that man's right to life, liberty, and the pursuit of happiness, should depend on the color of his skin." The tri-racial army — white, black, and nativegathering at Fort Gibson would soon fight side-by-side again, for after the victory at First Cabin Creek the Union seized the offensive and set out to strike a decisive blow against Confederate Indian Territory. ${ }^{360}$

A woman, her name lost to history, left Confederate Colonel Douglas Cooper's camp and headed north. Ostensibly a spy for the Confederate commander, she was in fact a double agent. Fifteen miles below Fort Gibson she slipped across the Arkansas River into Union-patrolled territory. The woman soon reported to Colonel William A. Phillips at Fort Gibson, producing dispatches hidden in her bonnet and full of news about Cooper's “modus operandi in getting news from the Union camp." Thankful for the information, Phillips sent the brave woman back to Confederate lines with misinformation, coffee, and whiskey to share with Douglas Cooper. "Believing that his thirst for the latter would be almost as great as his thirst for news," Phillips teased, "I sent him the desired articles, as an additional incentive to keep up the channel of communication."

\footnotetext{
360 "Report of Col. William A. Phillips," July 7, 1863, Official Records, vol. 22:1, 378-379; Britton, Memoirs of the Rebellion, 316, 328; Spurgeon, Soldiers in the Army of Freedom, 154-155.

${ }^{361}$ William A. Phillips to James G. Blunt, July 7, 1863, Official Records, vol. 22:2, 356-357.
} 
Keeping secrets in war-torn Indian Territory proved impossible. Whoever the daring young woman in both Union and Confederate employ was, she was one of many sources of information that kept Union and Confederate commanders well abreast of each other's whereabouts and strengths in the summer of 1863. Pickets bantered, refugees kept open eyes, travelers gossiped, and spies played friendly. Deadly games, but effective ones. Although mobility and weather offered elements of surprise and chance, relatively little escaped the notice of either General William Steele or Colonel William Phillips. It was through this intelligence network that Colonel Phillips knew of Steele's discombobulated state following Cabin Creek, and Federal officers sensed an opportunity.

The defeat at Cabin Creek left General William Steele worried. Appeals for arms, artillery, ammunition, provisions, and above all reinforcements fell on deaf ears in every quarter. Knowing the enemy could not be dislodged from Fort Gibson, Steele feared the Federals would try to cross the Arkansas and strike into southern Indian Territory and beyond. Heightened activity by the Federals along the Arkansas furthered Rebel suspicions of attack, and they forced Douglas Cooper's brigade to withdraw to Elk Creek, a small tributary of the Arkansas some twenty miles south along the Texas Road. From his headquarters at Fort Smith, General Steele determined to unify his two brigades - Cooper's Indians and Texans and Cabell's Arkansans — to face the enemy. The haggard condition of Cabell's Arkansas brigade delayed their departure, but on July 20, Cabell's troops marched out of Fort Smith accompanied by General Steele. ${ }^{362}$

${ }^{362}$ William Steele to W.R. Boggs, July 7, 1863, William Steele to William Cabell, July 10, 1863, William Steele to S.P. Bankhead, July 11, 1863, William Steele to W.B. Blair, July 13, 1863, William Steele to W.L. Cabell, July 15, 1863, and William Phillips to James G. Blunt, July 7, 1863, Official Records, vol. 22:2, 355-356, 909-911, 917, 921-922, 925, 933. Col. Asa S. Morgan's $26^{\text {th }}$ Arkansas Infantry of Cabell's brigade remained behind in Fort Smith to occupy that post. B.G. Duval to A.S. Morgan, July 15, 1863, Official Records, vol. 22:2, 933. Asa S. Morgan to wife, July 20, 1863, Asa Morgan Collection, AHC. 
North of the Arkansas River, Brigadier General James Blunt also grew concerned over the precarious state of the garrison at Fort Gibson and likewise determined to personally take charge of affairs of Indian Territory. On July 5, Blunt departed from Fort Scott with 350 troopers of the $6^{\text {th }}$ Kansas Cavalry and a section of artillery, riding, he declared, "to save the command or die in the attempt." Travelling rapidly, the boisterous Kansan general and his small outfit entered Fort Gibson on July 11, with a small but golden window of opportunity at hand. Blunt quickly learned of Cooper's retreat some fifteen miles below the Arkansas River; he was likewise informed that Cooper expected reinforcements in the coming days. "I determined to take the offensive," Blunt declared, "and strike him [Cooper] if possible before they could arrive."363 James Blunt's heroic arrival did not fundamentally change the daunting strategic situation faced the by the Union in Indian Territory. The Federal force at Fort Gibson likely hovered around 3,000. Reports placed Douglas Cooper's strength at 6,000, with Cabell en route with another 3,000. Rumors also suggested more reinforcements might arrive from Texas. Moreover, local geography hardly favored the Federals, either. The Arkansas River was swollen and couldn't be forded. The opposite bank was guarded by Rebel outposts fortified behind rifle-pits. Any attempt to cross the river would give Cooper, twenty miles south at Elk Creek, plenty of forewarning. Yet Blunt's decision to attack was a product of his nature. The Kansan earned victories against larger foes at Old Fort Wayne and Prairie Grove through decisive, aggressive action. He felt assured he could win. "I have now learned where the game is," he confessed, "and ache to get across the river." Observers trusted Blunt's generalship. "Those who know General Blunt, do not doubt his fighting qualities," penned Kansan trooper Wiley Britton. "It is safe,

${ }^{363}$ Blunt, "General Blunt's Account," 244; James G. Blunt to H.Z. Curtis, July 13, 1863, and James G. Blunt to E.M. Stanton, July 26, 1863, Official Records, vol. 22:2, 367-368, 398-399; Britton, Memoirs of the Rebellion, 342-343. 
therefore, to predict that the enemy will be obliged to fight very shortly, or retreat from their camp on Elk Creek.” Kansas newspapers hailed Blunt's departure to Fort Gibson, prophesying that "stirring news may soon be expected." 364

Having determined to attack, Blunt set about overcoming the immediate obstacle in his way: the Arkansas River. Unable to ford its swollen banks, Blunt oversaw the construction of three flatboats to ferry his command across. Under the night sky on July 15, Blunt set out with 250 cavalry, four pieces of artillery, and marched 13 miles upriver. After sending the enemy's pickets flying, his troopers forded the river, "taking the ammunition chests over in a flat-boat," and moved down the south side of the river. Blunt hoped his tiny command could capture the Rebel pickets opposite Fort Gibson from behind. The daring plan failed; the scouts fled back towards Cooper's camp. Meanwhile, the Federals spent the next day steadily ferrying their army across the Arkansas River. By the evening of July 16, the entire force had crossed. The Union army consisted of the $1^{\text {st }}, 2^{\text {nd }}$, and $3^{\text {rd }}$ Indian Home Guard, the $1^{\text {st }}$ Kansas Colored Infantry, and elements of the $2^{\text {nd }}$ Colorado Infantry, $6^{\text {th }}$ Kansas Cavalry, and $3^{\text {rd }}$ Wisconsin Cavalry. The Federals boasted an impressive array of artillery, including four guns of the $2^{\text {nd }}$ Kansas Battery, four guns of the $3^{\text {rd }}$ Kansas Battery (the formerly-Confederate guns captured at Old Fort Wayne), and four guns attached to the cavalry. At 10 p.m. on July 16, the intrepid blue-clad column set off to southward, hoping to decisively defeat their foes. ${ }^{365}$

364 "Report of Maj. Gen. James G. Blunt," July 26, 1863, Official Records, vol. 22:1, 447-448; Blunt, “General Blunt's Account," 243-244; James G. Blunt to H.Z. Curtis, July 13, 1863, Official Records, vol. 22:2, 367368; Britton, Memoirs of the Rebellion, 342-343; "Danger at Fort Gibson," The Smoky Hill and Republican Union [Junction City, KS], July 18, 1863; The Big Blue Union [Marysville, KS], July 18, 1863.

365 "Report of James G. Blunt," July 26, 1863, Official Records, vol. 22:1, 447-448; Blunt, "General Blunt's Account," 244. 
The young enslaved woman entertained a small child, swinging him from a grapevine on the large tree in the yard by the house. The little boy_-Istidji, meaning "little man"_-belonged to the woman's master, and the fifteen-year old girl had been bought specifically "to look after de little baby boy." And so Lucinda Davis pushed the boy along the grapevine, entertaining him in the cool summer air just before dawn. ${ }^{366}$

From her spot in the yard, Lucinda could survey the surrounding prairie and the nearby Texas Road. As she scanned the horizons that morning, she spotted a rider galloping across the plains toward the house, "jest a coming a-kiting and a-laying flat out on his hoss." As the rider approached, he let out a long war whoop and a warning: armies were marching their way for "a big fight," and everyone should flee. The rider then took off, continuing down the Texas Road whooping all the way. ${ }^{367}$

Lucinda Davis' master, an Upper Creek, immediately jumped into action, yelling for the family and slaves to pack up essentials in the wagon. The urgent work fell to the black women; the enslaved men had long since run off, including Lucinda Davis' uncle, who had joined the Union army's ranks. By the time the wagon was loaded, however, it was too late. Confederate Indian troops appeared on the horizon, followed by columns of butternut infantry and artillery. The sky darkened, and the morning skies opened up as the Southern soldiers slogged by. Lucinda Davis and the others simply watched from the roadside as the men marched off to war. ${ }^{368}$

Suddenly, the hollow boom of guns could be heard off to the north, sounding like "hosses lopin "cross a plank bridge." At the sound of violence, the Rebels hurried faster toward their fate. Lucinda, her fellow slaves, and their Indian masters took off across the prairie, taking shelter in a

\footnotetext{
366 Baker and Baker, eds., WPA Oklahoma Slave Narratives, 107-116.

${ }^{367}$ Baker and Baker, eds., WPA Oklahoma Slave Narratives, 107-116.

${ }^{368}$ Baker and Baker, eds., WPA Oklahoma Slave Narratives, 107-116.
} 
cave half-a-mile from the battlefield. The date was July 17, 1863, and the Battle of Honey Springs was set to begin. ${ }^{369}$

In the days prior to the battle, Brigadier General Douglas Cooper kept a wary eye on Federal movements to his north. The Confederate pickets along the Arkansas alerted Cooper to Union activity, and by the $16^{\text {th }}$ Cooper knew for sure that the Federals were crossing the Arkansas in some force. The question was how many were crossing, and to what purpose? Were the Federals launching a major invasion of southern Indian Territory, or merely setting out on a large scouting expedition $?^{370}$

Regardless of the Federals' intentions, Douglas Cooper felt relatively prepared. His brigade was nestled along Elk Creek, a shallow stream cutting west-east through the prairies south of the Arkansas River. Elk Creek was fordable in several places, but the strength of Cooper's position was not the waterway proper, but rather the heavy timber and brush that lined both banks. From timber's edge on the north side of the creek, the Confederates enjoyed a relatively open view of the rolling prairie to the north. The Texas Road, Indian Territory's vital north-south artery, bisected Elk Creek before passing Honey Springs, a small settlement a few miles south which served as a Confederate supply depot. If the Federals were going to march south, they would have to oust the Confederates from their position.

Having not only selected an excellent defensive position, Gen. Cooper further strengthened his position by organizing his oversized brigade into four commands, each responsible for defending a particular sector of the Elk Creek line. On the far right, the $1^{\text {st }}$ and $2^{\text {nd }}$ Cherokee Regiments under Col. Stand Watie guarded Elk Creek around a pair of lower fords.

\footnotetext{
${ }^{369}$ Baker and Baker, eds., WPA Oklahoma Slave Narratives, 107-116.

370 "Report of Brig. Gen. Douglas Cooper," August 12, 1863, Official Records, vol. 22:1, 457-461; Asa S. Morgan to wife, July 20, 1863, Asa Morgan Collection, AHC.
} 
The brigade's Texan regiments bore responsibility for holding the center of the Elk Creek line, through which the Texas Road forded the creek and continued south. The center consisted of the $20^{\text {th }}$ Texas Cavalry under Col. Thomas Bass, $29^{\text {th }}$ Texas Cavalry under Col. Charles DeMorse, and the $5^{\text {th }}$ Texas Partisan Rangers under Colonel Leonidas Martin; Col. Bass assumed overall command of the Texas forces. Supporting the Texans was Cooper's lone artillery battery, four light howitzers under Capt. Roswell Lee. The left wing guarded Elk Creek's upper fords and was comprised of the $1^{\text {st }}$ and $2^{\text {nd }}$ Creek Regiments, Col. Daniel McIntosh commanding. Finally, Col. Tandy Walker's $1{ }^{\text {st }}$ Choctaw and Chickasaw Rifles were kept in reserve alongside two small squadrons of Texan cavalry under Capts. Scanland and Gillett. The three wings of the Cooper's brigade were ordered to hold the timber line north of Elk Creek, posting sufficient skirmishers in the open prairie beyond. The entire force likely numbered around 5-6,000. ${ }^{371}$

Unfortunately for Douglas Cooper, his brigade was all that stood along Elk Creek in midJuly as the Federals marched south. From his headquarters at Fort Smith, General William Steele took solace in the raging waters of the Arkansas River, failing to account for General Blunt's audacity or ingenuity. Thinking the river's height afforded him more time than he really had, Steele spent several days preparing Cabell's brigade for the march west to reinforce Cooper. Contrary to popular myth, William Cabell's Arkansans were not anywhere near the battlefield on July 17. In fact, Gens. Cabell and Steele only departed Fort Smith on July 20, several days after the battle. Thus, through flawed assumptions and mismanagement, one of the two brigades assigned to the defense of Indian Territory was absent for the greatest battle that took place within its borders. It is somewhat fitting, then, that Confederate Indians and Texans, the political

371 “General Orders No. 25,” July 14, 1863, Official Records, vol. 22:1, 461-462. 
alliance that pulled the Five Tribes into the Civil War, would be responsible for fighting for the Confederacy's fate in the Territory on July $17,1863 .{ }^{372}$

As the Federals marched south, Cooper sent his reserve cavalry-Walkers' Choctaws and Chickasaws and Gillett's Texans — to patrol the roads north of Elk Creek leading from Fort Smith. As the sun rose into a cloudy, ominous sky on July 17, Confederate Indians and Texans spotted the vanguard of the Federal column several miles north of Elk Creek. After a full night's march, the advancing Federals were tired. Capt. William Gordon's Company F, $6^{\text {th }}$ Kansas Cavalry served as the column's advance that morning, and at daybreak they were electrified by the sudden appearance of Rebel cavalry to their front. Gordon's troopers came under a "brisk fire" and were driven back, only to be reinforced "at a gallop" by the other three companies of the $6^{\text {th }}$ Kansas. Now the Choctaws, Chickasaws, and Texans began to give way, and the two sides broke away as a steady rain began to fall from the sky. The Rebel cavalry fell back through the rain to the main line at Elk Creek, while the Kansans licked their wounds and slowly resumed their advance southward. ${ }^{373}$

As the Confederate cavalry arrived at Elk Creek with word of the Federal advance, they also carried more ominous news. During the opening firefight with the Kansans, many of the Rebels' firearms refused to fire. Indeed, as the skies opened up, quite a few Southern guns

372 William Steele to William Cabell, July 15, 1863 and B.G. Duval to Asa S. Morgan, July 18, 1863, Official Records, vol. 22:2, 933; Asa. S. Morgan to wife, July 20, 1863, Asa Morgan Collection, AHC. On July 15, Cabell penned Steele with news the Arkansas River was falling and "that troops moving toward Fort Gibson should be in position to re-enforce General Cooper as soon as possible," and ordering Steele to depart with whatever troops were ready. On July 18, Steele's adjutant informed Col. Asa Morgan of the $26^{\text {th }}$ Arkansas Infantry that his regiment would assume command once Steele departed; hence, Steele hadn't left Fort Smith by the $18^{\text {th }}$. On July 20, Asa Morgan wrote to his wife that the Federals had crossed the Arkansas, but Cooper wasn't sure if the enemy "is crossing his whole force or only a scout." Moreover, Morgan stated, "All the troops are to leave this place to day, except this Reg, we remain in chg [charge] of the Post." If Morgan's statement is accurate, Cabell's brigade didn't depart Fort Gibson until July 20. It is perhaps possible that Cabell left Fort Smith earlier with only part of his command; the lack of reports or communication from Cabell make it unclear when Cabell left Fort Smith.

373 "Report of Brig. Gen. Douglas Cooper," August 12, 1863, "Report of Maj. Gen. James Blunt," July 26, 1863, and "Report of Lieut. Col. William T. Campbell," July 19, 1863, Official Records, vol. 22:1, 447-448, 452453, 457-461. 
became "wholly useless." The Confederates' misfortunes owed to "the very inferior quality of the powder, the cartridges become worthless even upon exposure to damp atmosphere." For months and months, General William Steele requested, pleaded, and cajoled quartermasters in other departments for arms and ammunition. His pleas went unanswered, so Steele turned south and began purchasing Mexican gunpowder via agents in San Antonio. The Confederacy's inability and unwillingness to provision their Indian allies now came back to haunt it, for it was this paltry Mexican substitute that now failed many Confederate soldiers at Honey Springs. ${ }^{374}$

Having cleared the way of Confederate scouts, the Federals resumed their slog south. General Blunt and his staff officers rode ahead and found the main Confederate line amidst the brush and timber north of Elk Creek. As his exhausted troops approached the enemy position, Blunt directed them to take shelter behind a small ridge and take two hours' rest. A smart decision reflective of a caring commander, the opportunity to eat and rest helped rejuvenate the Union ranks. At 10 o'clock, the Federals roused themselves and formed into twin columns paralleling each other on either side of the Texas Road; Col William Judson led the column on the right, Col. William Phillips on the left. The Federals marched over the ridge and into the Confederates' view; a quarter-mile from the Rebel line the Union smoothly deployed from column to "line of battle, covering the enemy's entire front." On the Federals' right, a battalion of the $3^{\text {rd }}$ Wisconsin Cavalry secured the flank, followed by the $2^{\text {nd }}$ Indian Home Guard and the $1^{\text {st }}$ Kansas Colored Infantry, who deployed in the center of the Union line just to the right of the Texas Road. To the left of the Texas Road, the $2^{\text {nd }}$ Colorado Infantry also held the Union center. To the left of the Pike's Peakers stood the $1^{\text {st }}$ Indian Home Guard, while four companies of the

374 “Report of Brig. Gen. Douglas Cooper,” August 12, 1863, Official Records, vol. 22:1, 457-461. 
$6^{\text {th }}$ Kansas Cavalry secured the Federals' left flank. In one massive line of battle, the Federals advanced across the open prairie towards the Confederates who lurked in the brush ahead. ${ }^{375}$

The battle first erupted in the center. Three hundred yards from the Rebel's position, Capt. Henry Hopkin's four-gun Kansan battery barked into action near the Texas Road and began shelling the woods. Almost immediately, the Kansans drew a sharp response from Capt. Roswell Lee's four Texan guns posted amidst the Confederate center. A violent exchange of shot and shell "filled the air with booms and grape" for over an hour, the duel growing in scope as two 12-pound guns of Capt. Edward Smith's Kansas battery joined in the shelling from a position several hundred yards to the right of the Texas Road. Although the Kansan gunners suffered several casualties, the crossfire from six Union guns eventually silenced the Texas battery. ${ }^{376}$

While the artillery dueled, General Blunt rode up to Colonel James Williams of the $1^{\text {st }}$ Kansas Colored and ordered them forward in support of Hopkin's guns. "I wish you to keep an eye to those guns of the enemy," Blunt commanded, "and take them at the point of the bayonet, if the opportunity offers." Col. Williams turned to the black ranks of the $1^{\text {st }}$ Kansas and calmly informed them "we had work to do, and ordered them to 'fix bayonets." "Every man stepped promptly and firmly in his place," and the blue-clad African-Americans advanced to within 50 yards of the Rebels concealed in the brush. Alongside the Kansans to the left was the $2^{\text {nd }}$

375 "Report of Maj. Gen. James G. Blunt," July 26, 1863, "Report of Col. John Bowles," July 20, 1863, "Report of Col. Frederick W. Schaurte," July 20, 1863, "Report of Col. William T. Campbell," July 19, 1863, "Report of Col. Edward R. Stevens," July 19, 1863, "Report of Capt. Edward A. Smith," July 19, 1863, "Report of Maj. J. Nelson Smith," July 19, 1863, "Report of Col. Stephen H. Wattles," July 18, 1863, and "Report of Col. Henry Hopkins," July 21, 1863, Official Records, vol. 22:1, 447-457.

376 "Report of Capt. Henry Hopkins," July 21, 1863, "Report of Edward A. Smith," July 19, 1863, and "Report of Brig. Gen. Douglas Cooper," August 12, 1863, Official Records, vol. 22:1, 454, 456-461; Barney McDermott to Wife, July 22, 1863, R. McDermott Letters, $20^{\text {th }}$ Texas Cavalry File, HCHRC. Barney McDermott belonged to Company E, $29^{\text {th }}$ Texas Cavalry. His letters appear to be mis-catalogued as "R. McDermott" of the $20^{\text {th }}$ Texas Cavalry, but no such soldier existed. 
Colorado. Across the prairie, the men of the $20^{\text {th }}$ and $29^{\text {th }}$ Texas Cavalry and $5^{\text {th }}$ Texas Partisan Rangers lurked dismounted amid the brush. Armed with indifferent assortment of shotguns and hunting rifles, Barney McDermott and his comrades in the $29^{\text {th }}$ Texas could only "lay low," watching as the enemy "marched on firing as the came and killed our men before they came in range of our guns." The Texans were ordered "not to fire till the enemy came within forty yards." Again, poor equipment hindered Confederates fighting in Indian Territory. Yet the Federals marched ever closer, and the Texans took aim. ${ }^{377}$

At forty yards, the black Kansans pulled up alongside their white Colorado comrades, and at the order of Colonel Williams belched forth a volley. Simultaneously, the Texans unleashed a hellish volley of their own and "two long lines of smoke and flame" burst forth between the Union and Confederate lines. Private McDermott informed his wife, "When they came near enough, we let them have it and killed lots of them." In these fierce opening volleys, Col. Williams fell wounded, shot in the face, the right breast, and the hand, with his horse mortally wounded beneath him. Through the smoke and din of battle, the Kansans' second-incommand Lt. Col. John Bowles didn't know command devolved upon him. Instead of charging in with bayonet, black Kansans, white Coloradans, and Texan troopers simply stood their ground and exchanged brutal gunfire at forty yards. ${ }^{378}$

While the battle burned bright at its core, the fighting quickly spread to the flanks. Despite ample time to prepare for the Federal advance, not all of Douglas Cooper's regiments were in their proper positions when the fighting began, a symptom of Cooper's inability to keep

377 “Report of Col. John Bowles," July 20, 1863, Official Records, vol. 22:1, 449-450; Barney McDermott to Wife, July 22, 1863, R. McDermott Letters, HCHRC.

378 "Report of Col. John Bowles," July 20, 1863, Official Records, vol. 22:1, 449-450; Barney McDermott to Wife, July 22, 1863, R. McDermott Letters, HCHRC; Lull, Civil War General and Indian Fighter: James M. Williams, 92-93. 
a handle on small details. On the Confederate right, a small detachment of the $2^{\text {nd }}$ Cherokee fought alongside Bass' battered Texans. Beyond the $2^{\text {nd }}$ Cherokee, skirmishers of the $1^{\text {st }}$ Cherokee under Capt. Hugh Tinnin stretched out into an open flank. Instead of extending the Confederate line to the right as Cooper's pre-battle orders dictated, the bulk of the Cherokee regiments were instead in the right-rear along Elk Creek proper. The Confederate right flank was shorter than planned and was exposed. ${ }^{379}$

As Cooper rode forward along towards the Confederate center in the battle's opening hour, Capt. Tinnin's Cherokee scouts soon reported Federals advancing beyond the Confederate right flank. The advancing Federals, dismounted troopers of the $6^{\text {th }}$ Kansas deployed as skirmishers, were less a dedicated flanking party than a continuation of the main Union line. Personally responding to the threat, Cooper quickly ordered half of Thomas Bass' $20^{\text {th }}$ Texas to Tinnin's aid. The Rebel general also pulled forward the remainder of the $2^{\text {nd }}$ Cherokee from Elk Creek and personally placed them on the Confederate right flank. Tapping his reserves, half of the $1^{\text {st }}$ Choctaw and Chickasaw Mounted Rifles were also called up and sent to the right flank, posting them along prairie's edge. From his vantage point near the timber on the far right, Cooper could look out across the prairie to the north and see the battle unfold. "I had a full view of them," Cooper reported, and he was surprised at the enemy's strength, a force "larger than I supposed they would bring from Gibson." Not only were Federals advancing in open order on his right, but he could see the enemy advancing on his center and, most worrisome, he spotted "a heavy force wheeling off to their right and taking the road up the creek to the second crossing

379 “Report of Brig. Gen. Douglas Cooper,” August 12, 1863, Official Records, vol. 22:1, 457-461. 
above the bridge - our weakest point." In short, peering across the battlefield from the

Confederate right, Cooper realized the Federals threatened his immediate left. ${ }^{380}$

Riding away to the deal with yet another threat to his flank, Cooper left the fight on the right flank to evolve naturally. Cooper's reinforcements on the right flipped the tactical situation, and the Confederates began harassing the $6^{\text {th }}$ Kansas' harried flanks. The Kansans soon received help from the $1^{\text {st }}$ Indian Home Guard, however, and the situation stabilized. For nearly an hour and a half, a prolonged firefight simmered between Kansans and Indians in the prairie and Confederate Indians amid the timber. ${ }^{381}$

The threat to the Confederate left spotted by Douglas Cooper were troopers of the $2^{\text {nd }}$ Indian Home Guard, led by Lt. Col. Frederick Schaurte. After the initial artillery duel between Union and Confederate batteries, Schaurte led his men in skirmish order across the prairie towards the Confederates west of the Texas Road. The Indians soon found the Texans ahead among the timber, and the two sides picked at each other for several hours. ${ }^{382}$

Completely absent from this engagement were the $1^{\text {st }}$ and $2^{\text {nd }}$ Creek Regiments under brothers Daniel and Chilly McIntosh. Gen. Cooper's defensive plans for Elk Creek called for the Creek regiments to guard the "upper ford" of Elk Creek, some distance from the middle and lower fords, to secure the Confederates' left flank. As the battle opened on the morning of July 17, the Creeks dutifully placed themselves in position on the far Confederate left, with the twin Texan cavalry squadrons under Capts. Gillette and Scanland support. Among the Creek ranks that day was Lieutenant George W. Grayson, a well-educated Lower Creek who left Arkansas

380 “Report of Brig. Gen. Douglas Cooper," August 12, 1863, and "Report of Lt. Col. William T. Campbell,” July 19, 1863, Official Records, vol. 22:1, 452-452, 457-461.

381 "Report of Brig. Gen. Douglas Cooper," August 12, 1863, "Report of Lt. Col. William T. Campbell," July 19, 1863, and "Report of Col. Stephen H. Wattles," July 18, 1863, Official Records, vol. 22:1, 452-452, 455461.

382 “Report of Lt. Col. Frederick W. Schaurte,” July 20, 1863, Official Records, vol. 22:1, 451-452. 
College in Fayetteville to join the $2^{\text {nd }}$ Creek Regiment in 1862. Having never before faced battle, Grayson and his Creek countrymen took shelter in the "dense bottom" of Elk Creek and steeled themselves for violence. ${ }^{383}$

Hoping to rouse his Creeks to the moment, Col. Chilly McIntosh addressed his men "with the finest-war speech I ever heard,” Grayson would recall years later:

When you first saw the light, it was said of you 'a man child is born.' You must prove today whether or not this saying of you was true. The sun that hangs over our heads has no death, no end of days. It will continue indefinitely to rise and to set; but with you it is different. Man must die sometime, and since he must die, he can find no nobler death than that which overtakes him while fighting for his home, his fires and his country."

The speech worked as intended, and Grayson and the other Creeks "listened breathlessly at the rattle of small arms and an occasional exhausting whoop....anxious to take a hand in the affray." Grayson felt confident his men "could and would have made things alarmingly unpleasant for whomever they might be pitted against." 384

With the Colonels McIntosh, Lieutenant Grayson, and hundreds of Creeks listening to the roar of battle from their position on the Confederate left, there existed immense danger and opportunity for both the Federals and Confederates on that sector of the battlefield. The Creeks' far western posting on the upper ford meant there was a sizeable gap between the Creeks on the left and the Texans on the center. The $2^{\text {nd }}$ Indian Home Guard — the far right of the Union linewas thus skirmishing against the left flank of the Confederate center, held by the Texans. If the Creeks could sweep down from the upper ford of Elk Creek, they could endanger the Union right flank. If, however, the Creeks did not arrive in time, the left flank of the Texan center might fold.

383 “General Orders No. 25," July 14, 1863, "Report of Brig. Gen. Douglas Cooper," August 12, 1863, Official Records, vol. 22:1, 457-462; George Washington Grayson, A Creek Warrior for the Confederacy: The Autobiography of Chief G.W. Grayson, ed. W. David Baird (Norman: University of Oklahoma Press, 1988), 61-63. ${ }^{384}$ Grayson, Creek Warrior for the Confederacy, 61-63. 
When Gen. Cooper spotted the enemy first marching towards the Texans' left, he rode back towards the center of his line and fired off a dispatch to the Creeks, hoping to pull off just such a decisive movement. He ordered them to "move down and support [the Texans]....and, if possible, flank the enemy on our left." Yet Cooper's message never reached the Creeks. Instead of swooping to the Texans' rescue, the twin Creek regiments and accompanying Texan squadrons maintained a lonely, wasted vigil over Elk Creek's upper ford. Thus two whole Confederate regiments never engaged the Federals during the battle's decisive hours. ${ }^{385}$

Instead of waiting to ensure the Creeks arrived, Cooper sped off to the rear in search for reinforcements, hoping to bring up the rest of the Choctaw and Chickasaws held in reserve. Yet again, however, confusion reigned and troops were not where they were supposed to be. Mistaking an earlier order from General Cooper, instead of simply picketing a large hill in the Confederate right-rear, the entirety of Tandy Walker's troopers had moved to that location. Although Cooper still ordered them forward, their distance precluded any prompt arrival on the battlefield. Nearly two hours of sharp fighting in front of Elk Creek had elapsed, the battle was coming to a decisive crescendo, and there were no more Confederate reserves on hand. ${ }^{386}$

Around noon, the Confederate situation grew increasingly dire. The Texan regiments had withstood a beating for nearly two hours amid mounting casualties. Barney McDermott of the $29^{\text {th }}$ Texas lost two friends killed in the fighting, and watched another take a severe wound in the head and retreat to the rear. "The bullets came faster than any of the boys saw before," he confessed to his wife. The colonel of the $29^{\text {th }}$, Charles DeMorse, was wounded early in the the fray and forced to retire, turning command over to Lt. Colonel Otis Welch. Lee's Texas battery

\footnotetext{
385 "Report of Brig. Gen. Douglas Cooper," August 12, 1863, Official Records, vol. 22:1, 457-461.

386 "Report of Brig. Gen. Douglas Cooper," August 12, 1863, Official Records, vol. 22:1, 457-461.
} 
was equally savaged, having lost a gun to a direct hit by Federal counterbattery fire, the entire crew and all its horses either dead or wounded. The Texans were barely hanging on. ${ }^{387}$

The decisive moment hinged, oddly enough, on a small tactical error by the Federal $2^{\text {nd }}$ Indian Home Guard. Perhaps sensing they were closing in on the Texan flank, the Native troopers pushed forward in loose order until poised to enter the brushy timber of Elk Creek's northern bank. As the Indians pushed forward, they became disconnected from the black soldiers of the $1^{\text {st }}$ Kansas on their left. Lt. Col. John Bowles, finally assuming command for the fallen Col. Williams, realized the danger and ordered the $2^{\text {nd }}$ Indian to fall back into line. As the Indians fell back, the weary Texans to their front assumed the Federals were retreating. The Texans “commenced to press, as they supposed, upon a retreating foe. They advanced to within 25 paces," reported Lt. Col. Bowles, "when they were met by a volley of musketry that sent them back in great confusion and disorder." In the Texans' advance, their color-bearer was shot down. Twice more the flag was raised, only to be shot down again, eventually "left by the enemy as a trophy to our well-directed musketry." The attack repulsed, the Texans receded and their line soon began to buckle. ${ }^{388}$

The story of the Texan attack at Honey Springs, attributed by Lt. Col. Bowles to the $29^{\text {th }}$ Texas and the centerpiece of scholar's descriptions of Honey Springs, deserves closer scrutiny. This attack marked the crescendo of the battle, and its failure led the Confederate center to break. Understanding the circumstances regarding the attack is pivotal to unlocking the course of the engagement. The standard narrative of the attack hinges on the report of Kansan Lt. Col. Bowles,

\footnotetext{
${ }^{387}$ Barney McDermott to Wife, July 22, 1863, $20^{\text {th }}$ Texas Cavalry File, HCHRC; "Report of Lt. Col. Otis G. Welch," The Standard [Clarksville, TX], September 12, 1863.

388 “Report of Lieut. Col. John Bowles," July 20, 1863, Official Records, vol. 22:1, 449-451.
} 
and although it is unlikely that Lt. Col. Bowles fabricated the story, there exist grounds to question the accuracy of Bowles'-and thus historians'—narrative.

First, as noted earlier, the $29^{\text {th }}$ Texas Cavalry actually constituted the left flank of the Confederate line of battle at Honey Springs (discounting the Creek regiments, which were never engaged). The fight flank of the Union line was occupied by the $2^{\text {nd }}$ Indian Home Guard, with the $3^{\text {rd }}$ Wisconsin in support. It seems probable, then, that the primary foe facing the Texans across the open prairie was not black Kansans, but rather skirmishing Indians and Midwesterners. It's certainly possible that the right flank of the $29^{\text {th }}$ Texas perhaps engaged with the right flank of the $1^{\text {st }}$ Kansas Colored. If the $29^{\text {th }}$ Texas Cavalry was engaged with elements of three Union regiments, it's difficult to imagine them charging obliquely towards the Kansans with flank exposed to the Indians and Wisconsinites. In short, the $29^{\text {th }}$ Texas' position on the battlefield makes a full-throated charge upon the $1^{\text {st }}$ Kansas Colored unlikely. ${ }^{389}$

Second, no Confederate accounts support the theory the $29^{\text {th }}$ Texas made any forward assault. Gen. Cooper's report makes no mention of an assault, although given his position on the right and rear, his report is of limited value. Yet neither the reports of Col. Charles DeMorse or Lt. Col. Otis Welch of the $29^{\text {th }}$ Texas, subsequently printed in newspapers back home, indicate the Texans made an attack. In a letter to his wife written just days after the battle, Private Barney McDermott of the $29^{\text {th }}$ likewise fails to mention any advance. Almost certainly, the lines of the $29^{\text {th }}$ Texas and the enemy came very close to each other during the battle; Lt. Col. Welch even reported the enemy as nearing with twenty yards. But the failure by multiple officers and enlisted

${ }^{389}$ Captain Ethan Earle of the $1^{\text {st }}$ Kansas Colored stated, "Two Texan Regiments were stationed opposite the colored Regiment," which lends credence to the idea that perhaps part of the $29^{\text {th }}$ Texas fought the $1^{\text {st }}$ Kansas Colored alongside the $20^{\text {th }}$ Texas Cavalry (or alternatively, the second regiment may have been the $5^{\text {th }}$ Texas Partisan Rangers, whose precise position on the battlefield is unfortunately ambiguous in the sources). Captain Ethan Earle account book, NEHGS. 
of the $29^{\text {th }}$ Texas to report making any attack suggests the $29^{\text {th }}$ Texas Cavalry never attacked the enemy at Honey Springs at all. ${ }^{390}$

If we believe Lt. Col. Bowles' correctly witnessed a Texan attack, but discount the likelihood the $29^{\text {th }}$ Texas made the assault, which Confederates charged at Honey Springs? A plausible theory is that Lt. Col. Bowles simply misidentified the Rebel regiment to his front (of which there were likely several). It's possible that Col. Thomas Bass' $20^{\text {th }}$ Texas Cavalry made the decisive and failed attack at Honey Springs. The position of the $20^{\text {th }}$ Texas - to the right of the $29^{\text {th }}$ Texas, in the center of the Rebel line, with the $1^{\text {st }}$ Kansas Colored squarely to their front—supports such a theory. Multiple Confederate and Union accounts indicate the Confederate center collapsed at Honey Springs, including Lt. Col. Welch of the $29^{\text {th }}$ who reported that Bass' regiment to his right retreated first. A failed advance by the $20^{\text {th }}$ Texas might also help explain their inordinately high casualties during the battle. In short, if a Confederate charge indeed took place at Honey Springs, the circumstances suggest it was made by the $20^{\text {th }}$ Texas Cavalry, who swept forward only to be decimated, and subsequently retreated under pressure from the enemy.

Regardless of which Texan regiment made the advance, the Texan center soon began to buckle. The $20^{\text {th }}$ Texas Regiment gave way, followed by the right wing of the $29^{\text {th }}$ Texas. Meanwhile, the left flank of the $29^{\text {th }}$ Texas was threatened by the troopers of the $2^{\text {nd }}$ Indian and $3^{\text {rd }}$ Wisconsin, whose advance "forced the enemy to fall back upon their center." On the opposite side of the battlefield, the Confederate right flank was likewise pushed in by a charge of the $1^{\text {st }}$ Indian Home Guard, with the $6^{\text {th }}$ Kansas Cavalry supporting. Simultaneously, the entire

390 "Report of Brig. Gen. Douglas Cooper," August 12, 1863, Official Records, vol. 22:1, 457-461; "Report of Charles DeMorse," August 29, 1863 and "Report of Lieut. Col. Otis G. Welch," July 25, 1863, The Standard [Clarksville, TX], September 12, 1863; Barney McDermott to Wife, July 22, 1863, R. McDermott Letters, $20^{\text {th }}$ Texas Cavalry File, HCHRC. 
Confederate line crumbled. Riding to the front after his failed attempt to find reinforcements, General Cooper was surprised to find "our men in small parties giving way." Dallas Bowman, a Texan in the Choctaw and Chickasaw Rifles, admitted to his mother, "at last their firing began to get too heavy for us...we were compelled to fall back, and our men began to scatter which caused considerable confusion and we had a general stampede." Private McDermott put it more simply: "the Texas boys had to fly." 391

The Confederates retreated in broken fashion, pausing at several points within the brushy timber around Elk Creek in a futile effort to "make a stand with an attempt to check [the Federals'] pursuit." Unable to hold Elk Creek proper or any other point, General Cooper confessed, "Our forces were now in full retreat and the enemy pressing them closely." As the Confederates fled, they entered the open prairie south of Elk Creek and made their way toward the Confederate supply depot at Honey Springs. Fortunately for the broken Rebel regiments, some of the Confederate units held in reserve finally began to arrive. Capt. Gillette's Texan squadron arrived from the left flank and, taking a position along the Texas Road, slowed the Federals' pursuit. Shortly thereafter, Col. Tandy Walker's $1^{\text {st }}$ Choctaw and Chickasaw Rifles finally arrived and formed in the open prairie in front of Honey Springs. Determined to stave off the enemy and buy time for the Confederate army and its supply train to safely retreat, the mounted Choctaws and Chickasaws charged the advancing Federals, "giving them the war whoop." Although the Indians managed to delay the Federal advance, Union numbers ultimately forced them to retreat. As the Rebels retreated from the battlefield, they left behind considerable

391 "Report of Lieut. Col. Otis G. Welch," July 25, 1863, The Standard [Clarksville, TX], September 12, 1863; "Report of Capt. Edward R. Stevens," July 19, 1863, "Report of Lieut. Col. William T. Campbell," July 19, 1863, and "Report of Col. Stephen H. Wattles," July 18, 1863, Official Records, vol. 22:1, 452-453, 455-456; Barney McDermott to Wife, July 22, 1863, Robert McDermott Letters, HCHRC; Dallas Bowman to Mother, August 16, 1863, Dallas W. Bowman Collection, OHS. 
stores of flour, salt, sugar, and other sundry goods in the Honey Springs that couldn't be destroyed in time. The Federals found all these items "very acceptable," as some of them had been without food since departing Fort Gibson. ${ }^{392}$

The largest engagement fought in Indian Territory, by sheer numbers the Battle of Honey Springs was also the deadliest. Finding "the killed of the enemy very thick about us" at battle's end, the Federals reported burying roughly 150 Confederates. General Blunt claimed the Rebels lost another 400 wounded (a dubious figure) and 77 captured. General Cooper similarly reported 134 killed and wounded, with 47 taken prisoner. As he often did, Cooper inflated enemy casualties to above 200, when in fact the Federals lost 13 killed and 62 wounded. A fair estimate would suggest that total casualties numbered between 250 and $300 .{ }^{393}$

Like a pair of exhausted prize fighters after a nasty bout, the two armies retreated in the days following the battle. The victorious Federals, having crossed the Arkansas with the sole intention of defeating the enemy before they were reinforced, withdrew back to Fort Gibson for the time being. The Confederates - battered, bruised, and demoralized - withdrew south to relative safety beyond the Canadian River. The arrival of General William Steele—with William Cabell's long awaited Arkansas brigade in tow—several days after the battle strengthened the Rebel army to nearly 6,500. Moreover, a brigade of Texans under General Smith Bankhead was also en route. Although disappointed by the failure of Cooper and Cabell to link up prior to

${ }^{392}$ Captain Ethan Earle account book, NEHGS; "Report of Brig. Gen. Douglas Cooper," August 12, 1863, Official Records, vol. 22:1, 457-461; "Report of Lieut. Col. Otis G. Welch," July 25, 1863, The Standard, September 12, 1863; Dallas Bowman to Mother, August 16, 1861, Dallas Bowman Collection, OHS. Cooper reported that after their charge, the Choctaws and Chickasaws were once again "discouraged on account of the worthless ammunition."

${ }^{393}$ Captain Ethan Earle account book, NEHGS; “Report of Maj. Gen. James G. Blunt,” July 26, 1863, and "Report of Brig. Gen. Douglas Cooper," August 12, 1863, Official Records, vol. 22:1, 447-449, 457-461. A variety of other accounts loosely corroborate these casualty figures (excluding Blunt's fictitious declaration of 400 enemy wounded). On July 22, Steele reported that " 200 will more than cover [Cooper's] loss, killed, wounded, and missing." William Steele to Smith Bankhead, July 22, 1863, Official Records, vol. 22:2, 940. 
battle, Steele hoped to revive his dreams of bagging the Federal supply train to Fort Gibson and starving the Federals out of Indian Territory. Yet the reality of the Confederate situation soon disabused Steele of the notion. ${ }^{394}$

The defeat at Honey Springs deeply demoralized the Confederate army in Indian Territory. A few days after the battle, Private Barney McDermott bluntly declared to his wife, "I believe they will whip us and whip us all the time until we are reinforced from Texas or some other point. They are too strong for us....I know it for I have tried them and they are as good as we are, better drilled and armed." Privates David Dumas and John Howard both stumbled upon Col. Thomas Bass crying along the riverside in the days following the engagement - Bass' $20^{\text {th }}$ Texas Cavalry had suffered nearly half the Confederate army's losses at Honey Springs. Moreover, logistical problems continued to haunt the men. "The morale of the troops is considerably affected by the band quality of powder which we have," complained General Steele. Rumors flew that the Yankees purposefully gave Mexico inferior gunpowder to supply the Rebels. Among Cabell's Arkansans, poor morale and distaste for service in Indian Territory soon spurred massive bouts of desertion; by August, Arkansans were first "leaving nightly by tens and fifties," then "hundreds in a single night," often accompanied by officers. Confederate confidence — in their fighting ability, in their training, in their equipment — was shaken. ${ }^{395}$

The military events of the next few months did little to revive Confederate spirits. The Arkansas reinforcements were proving worthless. The mass desertions among Cabell's Arkansans forced Steele to isolate their brigade, for fear the Arkansans' sour morale would foster

\footnotetext{
${ }^{394}$ William Steele to Smith Bankhead, July 22, 1863, and William Steele to W.B. Blair, July 29, 1863, Official Records, vol. 22:2, 940, 950-951.

395 Barney McDermott to Wife, July 22, 1863, R. McDermott Letters, $20^{\text {th }}$ Texas Cavalry File, and David E. Dumas, "War Notes as Remembered by David Elhanon Dumas," $5^{\text {th }}$ Texas Partisan Rangers File, HCHRC; Yeary, ed., Reminiscences of the Boys in Gray, 351; William Steele to W.B. Blair, July 22, 1863, August 7, 1863, and August 9, 1863, and William Steele to S.S. Scott, August 7, 1863, Official Records, vol. 22:2, 956-957, 961.
} 
desertions in other regiments. Steele first sent the Arkansans south towards the Canadian and Red Rivers, then in mid-August ordered them back east towards the vicinity of Fort Smith. Within the span of a few weeks, despite reinforcement, Steele's army was no larger than it was at Honey Springs. ${ }^{396}$

While Confederate reinforcements deserted en masse, the Union army at Fort Gibson continued to grow. On August 22, having heard reports that various Confederate commands had coalesced around General Steele, General Blunt crossed the Arkansas River with 4,500 to again take the fight to the enemy. Unbeknownst to Blunt, his offensive came at a fortuitous moment. Cabell's Arkansans had already left Steele's camps, and reinforcements from Texas had yet to arrive. Marching south along the Texas Road, on Federals soon approached Perryville, Choctaw Nation, a tiny village that served as a major supply depot for Confederate forces. Although Steele's army held Perryville, the sad state of his army and the Federals' superior numbers convinced Steele to decline battle. On August 25-26, Confederate skirmishers fended off the Union advance long enough for the Confederate army and supply train to retreat. As at Honey Springs, the Rebel supply train escaped but the depot stores did not. Believing "nearly every building contained Government stores," General Blunt simply ordered "the burning of the whole place." 397

William Cabell's brigade of insubordinate Arkansans, sent in the direction of Fort Smith to help defend that place, met equally dismal results. Having burned Perryville, Blunt turned east in pursuit of Cabell. The two forces skirmished in the vicinity of Skullyville in Choctaw Nation

396 William Steele to W.B. Blair, August 7 and August 9, 1863, and William Steele to William Cabell, August 19, 1863, Official Records, vol. 22:2, 956-957, 961, 972.

397 "Report of Maj. Gen. James G. Blunt,” August 27, 1863, "Reports of Col. William F Cloud,” August 27 and September 8, 1863, and "Report of Brig. Gen. William Steele," August 28, 1863, Official Records, vol. 22:1, 597-600; William Steele to W.R. Boggs, August 30, 1863, Official Records, vol. 22:2, 984; Blunt, "General Blunt's Account," 246-247. 
on August 30-31, but Cabell wisely fell back toward Fort Smith, and Blunt sent a mixed force of infantry, cavalry, and artillery in pursuit under the command of Col. William Cloud. On September 1, Cloud's Federals brought Cabell's force to heel near Devil's Backbone, a large rocky spur 16 miles south of Fort Smith. Determined to hold his ground and allow his supply trains time to reach Fort Smith, Cabell placed his troops in various defensive lines running up the Backbone. The Federals advanced upon the position in the early afternoon, attacking along the length of the Rebel line. At the outbreak of gunfire, the bulk of the Arkansans simply fled. "There was nothing to make these regiments run," raged Cabell, "except the sound of the cannon." Despite most of his men instantly routing, Cabell managed to stave off the advancing Federals for three hours before retreating southeast, having given the supply trains sufficient time to escape. The disgraceful defeat at of Cabell's Arkansans at Devil's Backbone left Fort Smith virtually defenseless, and on that afternoon the Union army "quietly entered the town." General Blunt ordered the Confederate flag lowered and hoisted Old Glory above the post for the first time since 1861.398

The string of Federal victories in the summer of 1863 - the sharp victory at Honey Springs, the burning of Perryville, the fight at Devil's Backbone and subsequent occupation of Fort Smith — fundamentally altered the military situation in Indian Territory. With Fort Gibson and Fort Smith firmly in Union hands, the Confederacy’s Arkansas River line proved untenable. The Confederates were forced back south beyond the Canadian River, and the territory between the Arkansas and Canadian became a veritable no-man's land. Although many of the white

398 "Report of Maj. Gen. James G. Blunt," September 3, 1863, "Report of Col. William F. Cloud," September 20, 1863, and "Report of Brig. Gen. W.L. Cabell," December 7, 1863, Official Records, vol. 22:2, 601609; Blunt, "General Blunt's Account," 246-247. 
regiments tasked with assisting their Indians allies in 1863 were of poor quality, never again would the Confederacy devote as much manpower to the defense of Indian Territory. Cherokee Nation was irretrievably lost, Creek and Seminole Nations occupied a see-sawing no-man's land, and Choctaw and Chickasaw Nations lay vulnerable to the south. The occupation of Fort Smith was followed by the subsequent fall of Little Rock in mid-September, and in general Confederate forces sullenly withdrew into southern Indian Territory and southern Arkansas. The tide of war in Indian Territory, Arkansas, and the Trans-Mississippi shifted in the Federals' favor, mirroring Union strategic successes at Vicksburg and Gettysburg east of the Mississippi River.

Beyond the strategic implications of these setbacks, the disastrous string of defeats also produced a profound crisis of loyalty among the Confederacy's remaining Native American allies. After Honey Springs, the Creeks withdrew in upon themselves. Daniel and Chilly McIntosh's regiments retreated into Creek Nation and refused to leave its boundaries, ignoring General Steele's summons. Essentially abandoning the Confederacy in favor of a strict defense of their own nation, Steele worried the Confederate Creeks might defect altogether. ${ }^{399}$

More worrisome were signs of discontent among the Choctaws, widely considered staunch Southern supporters. For the first time in the war, Federal soldiers penetrated into Choctaw Nation during the Perryville expedition and the pursuit of General Cabell. Feeling the sting of war and "disgusted" by the military situation, Union reports suggested the Choctaws "are disposed to lay down their arms... friendly members of the Nation at work, and have strong hopes that they will cease to fight, and return to treaty relations. ${ }^{\circ 400}$

${ }^{399}$ William Steele to W.B. Blair, July 29 and August 9, 1863, Official Records, vol. 22:2, 950-951, 961. Gen. Steele specifically complained that the Creek regiments ignored an order to reinforce Perryville, and thus the Creek regiments were not present with Steele's force when the Federals advanced on that place and burned the town. "Report of Brig. Gen. William Steele," August 28, 1863, Official Records, vol. 22:1, 599-600.

400 "Reports of Col. William F. Cloud," August 27 and September 8, 1863, Official Records, vol. 22:1, 598599. 
Hoping to stamp out dissent within their tribe, the Choctaw National Council took up the matter in their October sessions. The Council passed a resolution condemning neutrality and affirming their loyalty to the Confederacy. Even more decisively, they declared that any who sought "to destroy the confidence of the Choctaw people in the ability of the Confederate States to sustain themselves" or "to induce this people to occupy a position of neutrality, or withdraw their united support from the Confederates States, shall be a deemed and considered an enemy to this Nation of people... and deserving the death of a traitor." The draconian resolution suggests that pro-Confederate Choctaw leaders took internal dissent seriously. ${ }^{401}$

Also frustrated with the Confederacy was Cherokee Colonel Stand Watie, their most prominent and reliable Indian officer. In early August, Stand Watie wrote a flurry of letters revealing his disillusionment with the Confederacy while likewise seeking to bolster Indian morale. In a personal appeal to the Choctaw and Chickasaw Nations, Watie confessed, "Every day seems to drive conviction to my heart that we, the Indians still true to the South must place small reliance on assistance from abroad...I am loth to believe the Confederate authorities have entirely abandoned the Cherokee country, but I see in the future scarcely a ray of hope from them." In a similar appeal to Creek officials, Watie admitted, "The promised protection of the Confederate has been hardly observable... I much fear that we can reasonably look for no change for the better, but that the Indians will have at last to rely upon their own exertions in the defense of their country." Writing angrily to Lieutenant General Edmund Kirby Smith, commander of the entire Trans-Mississippi Department, Watie frustratingly demanded, "Can you give me assurances of effective aid for the Indians? Or shall I renounce forever all expectations of adequate assistance, and tell my people to rely upon themselves, and go down to ruin if they

401 "The Loyalty of the Choctaws," The Standard, November 9, 1863. 
must in a manly effort to defend their homes." From Stand Watie's perspective, Confederate Indians could simply no longer trust the Confederacy, and instead must rely upon each other for defense in the coming days. ${ }^{402}$

Other Confederate Indian officers felt similarly. Captain James Bell, an officer in Stand Watie's command, requested a transfer in September of 1863. "We get neither justice or our rights and I am not inclined to be an idle observer of the wrongs of my people any longer," Bell declared. "If to be a Southern man, to be alive to all the interests of the South \& the Struggle they are engaged in etc. would entitle them to any consideration whatever or to a just proportion of notice in the different reports of Engagements with the Enemy, our people are justly deserving. What have they ever received by slights and neglect." To Watie directly, Bell wrote, "Shall we bear it any longer or will you command us to bear it longer, if so you are knowing to the wrong and encouraging it and we must regard you in the light of an Enemy." Although Watie convinced the zealous young James Bell to remain the ranks, Bell's frustrations actually mirrored those of Watie and many Confederate Indians that summer. The Confederacy let them down. ${ }^{403}$

Ultimately, those Native Americans who still stood by the Confederacy in 1863 continued to do so for the remainder of the war. There were no more mass defections as in 1861 or 1862, though perhaps some Indians still quietly pined for neutrality or peace. These Confederate Indians were true believers in the necessity of winning the war, if no longer the Confederacy as meaningful allies. As Stand Watie declared, "The only expectation of the North to conquer the Indians Nations, is in the traitors that have deserted us, the negroes they have

${ }^{402}$ Stand Watie to Governor of Choctaw and Chickasaw Nations, August 9, 1863, Official Records, vol. 22:2, 961-962. Stand Watie to unknown [likely Creek official], August 9, 1863, and Stand Watie to Lt. Gen. E. Kirby Smith, August 9, 1863, Stand Watie Collection, Oklahoma Historical Society, Oklahoma City, OK. Reverend Stephen Foreman, after a visit to Col. Watie's camp on August 8, recorded in his diary that "The Col. had but little say, yet I thought he spoke more discouragingly than I ever heard him." Stephen Foreman diary, August 8, 1863, Stephen Foreman Papers, WHC, OU.

${ }^{403}$ James M. Bell to Stand Watie, September 24, 1863, Cherokee Cavaliers, 141-142. 
stolen from us, and a few Kansas jayhawkers they can spare from that detestable region. Shall we allow ourselves to be subjugated and enslaved by such a class? No! Never!!"404

Yet the disappointment and disillusionment harbored by the Confederacy's Indian allies by the autumn of 1863 speaks to the profound failure of the Confederacy to fulfill her treaty obligations to the Five Tribes. Required by treaty to keep white troops stationed in Indian Territory, for the most part the Confederacy simply consigned its worst soldiers to the Territory. Speight's Texas brigade, assigned to the Department over winter before being sent to Louisiana in the spring of 1863 , suffered from deep demoralization and a lack of supplies. They were replaced by William Cabell's brigade of Arkansans, who failed to ever find the field of battle that summer. Indeed, William Steele and Douglas Cooper may actually have been worse off for having Cabell's Arkansans in their ranks, given that the Arkansans' dissatisfaction and desertion ran like poison through the ranks. Although the three Texan regiments - the $5^{\text {th }}$ Texas Partisan Rangers, the $20^{\text {th }}$ Texas Cavalry, and the $29^{\text {th }}$ Texas Cavalry—directly attached to Douglas Cooper's Indian Brigade proved their worth in blood at Honey Springs, they were not enough. Excepting those three Texan regiments, the rest of the white troops assigned to Indian Territory in 1863 were mostly worthless.

Beyond manpower, the Confederacy likewise ignored the material needs of their Indian allies. Confederate Indians and their Texan allies were almost universally ill-equipped, poorly clothed, under paid. They marched on empty bellies, alongside broken-down wagons and jaded horses. They often lacked arms and ammunition. As Stand Watie complained, "The Indian troops who have been true to the Southern cause from the very first, have been treated in many instances as though it were immaterial whether or not they were paid as promptly, or equipped as

${ }^{404}$ Stand Watie to unknown [likely Creek official], August 9, 1863, Stand Watie Collection, OHS. 
thoroughly as other soldiers." The Confederacy's failure to secure a substantial quantity of quality gunpowder for Indian Territory forced William Steele to turn to San Antonio and Mexico beyond, a dubious pipeline that paid terrible dividends during the Battle of Honey Springs, when Confederate powder turned to paste. ${ }^{405}$

Of course, even had the Confederate soldiers been supplied with quality gunpowder, it hardly would've rectified the wretched state of their guns. Those with firearms usually toted shotguns, hunting rifles, and other antiquated arms that possessed a limited range and required constant repair. When trading shots with Federal pickets across the Arkansas River, Rebel bullets fell short. At Honey Springs, Confederate soldiers withstood Federal fire for some time before they could return the favor, simply because their weapons couldn't range that far. Almost needless to say, the Rebels in Indian Territory likewise lacked artillery. At Cabin Creek, Confederates endured a veritable storm of grape and shell, unable to respond because they had no guns of their own. At Honey Springs, the Confederate's lone Texas battery was outgunned, overmatched, and knocked about. If the fighting quality and morale of Confederate troops in Indian Territory sometimes lacked, perhaps it was partially owed to the disgraceful material circumstances in which they constantly found themselves. The shortfalls of the Confederacy in providing for its Native allies, whether in men or guns or accoutrement—severely harmed the Confederacy's military performance in Indian Territory.

The Confederacy's inability and unwillingness to provide men and material to Indian Territory throughout the war stemmed from several factors. Undeniably, the Confederacy simply didn't have enough to go around. Fighting a losing war against an amply-supplied opponent advancing on all fronts, the Confederacy was forced to prioritize where its men and materials

${ }^{405}$ Stand Watie to S.S. Scott, August 8, 1863, Stand Watie Collection, OHS. 
were needed most. Indian Territory ranked near the bottom of the list. The Confederacy routinely prioritized the defense of Arkansas, Missouri, Louisiana, or Texas throughout the war. From a military perspective, such triage made sense. Simply put, Little Rock or Helena or Shreveport or Springfield were strategically more valuable than Tahlequah or Doaksville or North Fork Town. This is not to say the Confederacy saw no strategic value in Indian Territory. Many Confederate leaders and citizens believed it important that Indian Territory remain in Rebel hands, if anything to keep Texas and Western Arkansas secure. But when forced to choose, the Confederacy valued Indian Territory less.

Hard military realities were not the only factor at play, however. Many Confederates, especially as the war dragged on, came to view their Indian allies as militarily and racially inferior. In the winter of 1863, frustrated in his defense of Indian Territory and increasingly unpopular with men and officers alike, General William Steele relinquished command of the Department of Indian Territory. In his final report, he opined "that, with a few exceptions, the Indians are wholly unreliable as troops of the line. The officers, as a general rule, are ignorant, void of moral tone of character, and indisposed to enforce discipline among their men.” The Indians seemed to think their military service "a voluntary contribution on their part, susceptible of being withheld at their option." Steele's poor opinion was shared by many other Rebel soldiers, who were mystified and disdainful of the Native Americans' lack of discipline, constant furloughs (official or not), odd martial customs and war-whoops. In white Confederate eyes, their Native Americans allies weren't worth much as soldiers. ${ }^{406}$

Faced with a shortage of guns in 1862, one Fort Smith quartermaster griped, "This dogon Indian business is enough to break up any government in the world... some 3,000 or 4,000

406 “Report of Brig. Gen. William Steele," February 15, 1864, Official Records, vol. 22:1, 28-36. 
stand of fine arms, and plenty of ammunition, are uselessly had and destroyed by these noaccount Indian commands. Stand Watie's is the only one worth a cent, and they are mostly white men." Even Stand Watie, however, was not above reproach. In the spring of 1864, Watie was promoted to brigadier general, becoming the Confederacy's only Native American general officer. Yet Watie's promotion outraged Col. Charles DeMorse of the $29^{\text {th }}$ Texas Cavalry, who asserted "The Indian is a physiologically recognized as an inferior race, and I respectfully protest against the decision... as one to which no white officer, with a proper respect for the natural dignity of his race, can submit." The complaints of these white officers hint at the derisive racial views many Confederates possessed in regards to their Indian comrades. These views are hardly surprising. White Confederates were engaged in building a white-man's slaveholding republic, after all, and for centuries Southerners had enslaved, killed, and expelled Native Americans across the continent. Although eager to secure Indian Territory at war's outbreak, many Confederates carried racial scorn for the Territory's Native denizens. ${ }^{407}$

The failure of the Confederacy to fulfill its treaty obligations, due to material shortages and racial prejudice, severely hampered Confederate military efforts in the summer of 1863 and played a decisive role in the defeats of Cabin Creek and Honey Springs. Certainly other factors were critical. The mediocre leadership of Confederate Generals William Steele and Douglas Cooper stands in sharp contrast to the aggressive, confident offensives of General James Blunt and Colonels William Phillips and William Cloud. The bravery and combat effectiveness of the Union rank and file—including white, Native American, and African-American soldiers—is

${ }^{407}$ N.B. Pearce, July 5, 1862, Official Records, vol. 13, 963-965; Charles DeMorse to Douglas Cooper, 1863, Official Records, vol. 34:4, 699-700. Historian Charles Grear has explored the conflicted relationship between white Texans and their Native American allies, contending that while Indians and whites worked well-enough together while campaigning, "once there was a lull in fighting, the Texans and Indians would often fight each other." Charles D. Grear, "Red and White Fighting the Blue: Relations between Texans and Confederate Indians," The Seventh Star of the Confederacy: Texas during the Civil War (Denton: University of North Texas Press, 2009), 167188. 
clear. Yet at every turn the Confederacy's broken promises, material shortfalls, and substandard reinforcements weakened their defense of Indian Territory. As Cherokee Reverend Stephen Foreman simply stated, "All believe that one fact develops itself, and that is, that the Indians are not cared for, and that the Confederate States are throwing them off to shift for themselves as best they can." Although the Confederacy bore great responsibility in pulling the Five Tribes into the war, in the end, they left their Native American allies to fend for themselves, to disastrous ends. 


\section{"The Evils of Disunion, Discord, and War": Raids, Refugees, and Homefront, 1864-1865}

"We can see nothing but Starvation before us, already we have had a taste of what is to come this winter...It was a terrible mistake that we were not brought down here in time to raise a crop for ourselves, had that been done, we could in great measure have supported ourselves."

-Creek leaders to Commissioner William Dole ${ }^{408}$

The decisive defeat at Honey Springs undermined the Confederacy's ability to regain control of the Arkansas River Valley and the heart of Indian Territory. Unable to challenge the Federal army directly, Confederate forces in Indian Territory instead found themselves caught up in wider Trans-Mississippi affairs, making bloody and controversial contributions against the 1864 Federal Camden Expedition in southern Arkansas. They also engaged in a series of spectacular raids that boosted both Confederate soldiers' morale and physical comforts considerably. Yet these splashy victories proved hollow and did little to change the strategic outlook in the Trans-Mississippi or Indian Territory. Federal control over the Arkansas River Valley, if not the surrounding countryside, remained relatively secure.

While the Confederacy failed to reverse the war's tide in the region, the humanitarian crisis in Indian Territory continued to grow unabated. The Loyal Indian refugees - having endured years of refugee life in Kansas - finally returned home, only to find little food or provisions for the winter ahead. Confederate Indians fled southward as the Union tightened their control of the Arkansas River Valley — refugees flooded Choctaw and Chickasaw Nation along the Red River and spilled over into northern Texas and southern Arkansas. Although banditry, murder, assassinations, and theft plagued Indian Territory throughout much of the war, a

408 Oktaharsharjo, et. al. to William P. Dole, July 16, 1864, Creek Agency, Letters Received by the Office of Indian Affairs, 1824-1880 (hereinafter referred to as Letters Received, OIA), Records of the Bureau of Indian Affairs (RBIA), National Archives, Washington, D.C. 
veritable no-man's land arose in the war's latter years that facilitated a greater wave of violence and terror. By the end of the war, the majority of Indian Territory's denizens were refugees, reliant upon either the Union or Confederate governments for sustenance and survival.

After four years of intra-tribal warfare, endless campaigning, guerrilla attacks and raids, banditry, starvation, disease, refugee crises, and death, the Civil War in Indian Territory boiled down to an uncertain end in the summer of 1865. As the Confederacy collapsed, the Five Tribes met in council, hoping to present a united front towards the United States as Reconstruction loomed. They sued for peace, and in June, Brigadier General Stand Watie became the last Confederate general to surrender his command. The war was over. Yet Native Americans in Indian Territory possessed relatively little leverage with the Federal government as Reconstruction loomed. They worked to present a unified front towards the United States and hoped to negotiate the best treaties possible in the face of an uncertain future.

As 1864 dawned, Native Americans in Indian Territory found that the war had left them behind. Having failed to dislodge the Federals from Fort Gibson the summer previous, the Confederacy simply didn't have the manpower or material strength to launch another sustained offensive north. Instead, Southern commanders in Indian Territory contented themselves to raiding and trying to keep the Federals out of North Texas. Although the Federals occasionally extended their reach beyond the Arkansas River, they were largely content with control of Fort Gibson itself. A miniature Gibraltar, Fort Gibson allowed the Federals to transport men and goods via the Arkansas River and likewise gave them control over much of Cherokee Nation. As the war ground into its third year, both the United and Confederate States shifted their strategic focus elsewhere in the Trans-Mississippi. 
None of this boded well for the newly appointed Confederate commander in Indian Territory, Brigadier General Samuel Bell Maxey. The latest in the revolving door of Confederate district commanders, Maxey replaced the bitter and unpopular William Steele early in 1864. Yet Sam Maxey's background left him admirably suited for the challenge. A native of Kentucky, Maxey graduated from West Point in the famous Class of 1846 alongside Thomas "Stonewall" Jackson, George Meade, George McClellan, A.P. Hill, and others. Maxey saw combat as a junior infantry officer in the Mexico City campaign, earning accolades at Cerro Gordo and Contreras. Maxey resigned his commission following the war, practiced law, and moved to Texas. At the outbreak of the Civil War, Maxey raised a regiment of Texas infantry and earned an early promotion to brigadier general, followed by action in East Tennessee and during the Port Hudson and Vicksburg Campaigns. A well-educated, experienced military officer sensitive to both Indian and Texan politics, Maxey was perhaps the most professional, qualified Confederate commander in Indian Territory during the war. ${ }^{409}$

Like many district commanders before him, Maxey assumed command with aspirations of taking the offensive and reclaiming Indian Territory north of the Arkansas. And also like his predecessors, the demanding strategic, material, and political realities of Indian Territory quickly disabused him of the notion. Maxey inherited a district beset with every problem imaginable.

\footnotetext{
${ }^{409}$ Warner, Generals in Gray, 216; Louise Horton, Samuel Bell Maxey: A Biography (Austin: University of Texas Press, 1974); John C. Waugh, Sam Bell Maxey and the Confederate Indians (Abilene, TX: McWhiney Foundation Press, 1998). For a largely managerial commander, much ink has been spilled on Samuel Bell Maxey, likely a reflection of the voluminous papers he left behind that are today preserved in several archives. Nancy Hobson's essay "Samuel Bell Maxey as Confederate Commander of Indian Territory" in The Civil War Era in Indian Territory (1974) offers a dated overview of the general's tenure in command. John C. Waugh's more recent Sam Bell Maxey and the Confederate Indians (1995) gives a glowing review of the general but overlooks several notable events (such as the racial massacre at Poison Springs) that marred Maxey's career. Finally, Louise Horton's Samuel Bell Maxey: A Biography (1974) provides a full biographical account of the soldier and politician's life, but only a lone, brief chapter covers Maxey's Confederate service. Despite these many works, there is room for a more balanced, in-depth examination of Maxey's contributions to Confederate-Indian relations and the Confederate war efforts in the Trans-Mississippi.
} 
Indian Territory was destitute of food, arms, clothing, or military equipment. Native allies' faith in the Confederacy was shaky, and desertion rampant. Leadership among the Rebel ranks was poor. Years of campaigning, guerrilla warfare, and banditry left the civilian population increasingly homeless and hungry. In short, the Rebel outlook was bleak. Writing to the newly appointed General Maxey, one Confederate officer admitted, "Northern Texas and the Indian Department have been neglected so long that they have become the most difficult and the most responsible commands in the Trans-Mississippi Department. I tremble for you.” Maxey himself confessed to his wife, "Truly this is a Herculean task...If I do succeed, I think I ought to be entitled to some credit." ${ }^{\prime 410}$

One of General Maxey's first tasks was shoring up the fraying alliance between the Confederate States and its Indian allies. The defeats of 1863, combined with the consistent failure of the Confederacy to live up to its material promises, left pro-Confederate tribal governments questioning the value of their alliance to the weakening Confederacy. These issues nearly boiled to the surface in early February at Armstrong Academy in Choctaw Nation. There, a "Grand Council" of the pro-Confederate Indian tribes met to discuss their collective course of action. Tribal leaders gathered and discussed strategic options, including forging better relationships with Plains tribes and the possibility of raiding into Kansas. Yet dissatisfaction with the Confederacy and the war reared its head. Colonel Douglas Cooper admitted that only with tribal pressure could Choctaw Chief Samuel Garland and other "grumblers and croakers...be

\footnotetext{
${ }^{410}$ Samuel Roberts to Samuel Bell Maxey, February 1, 1864, Official Records, vol. 34:2, 936-937; Samuel Bell Maxey to Marilda Maxey, December 29, 1863, Samuel Bell Maxey Papers, Gilcrease Institute (hereinafter referred to as GI).
} 
hushed and the soft-shells crushed out." Maxey himself gave an address to council to assuage their concerns, which was well received. ${ }^{411}$

Further placating the Indian tribes, Maxey agreed to reorganize his military command into three distinct Indian brigades formed along tribal lines: Cherokee, Choctaw and Chickasaw, and Creek and Seminole. With nearly 8,000 Native Americans enlisted in Confederate service (though likely less than half in the field), multiple brigades were warranted. Moreover, it was hoped the reorganization would help spur recruitment and retention. The creation of new brigades also placated Douglas Cooper, whose dissatisfaction at being passed over for district command was well-known. With two new brigades, Colonel Douglas Cooper earned a promotion to brigadier general. ${ }^{412}$

While General Maxey tried to keep the frayed threads of Indian alliances together, the Federals at Fort Gibson stirred. Although the United States kept only a small garrison at the post and held no real desire to conquer south of the Arkansas River, Colonel William A. Phillipswho so valiantly defended the post the summer previous—-sought to build on his prior successes and launched a raid in Choctaw and Chickasaw Nations in hopes of undermining Maxey's work and permanently splintering the alliances between the South and its remaining Indian allies.

Colonel William Phillips inaugurated his grand raid south with a proclamation. His bold words circulated among the soldiers of Fort Gibson in the days before the march south. "Soldiers! I take you with me to clean out the Indian Nation south of the [Arkansas] river and

${ }^{411}$ Israel G. Vore to Samuel Bell Maxey, January 29, 1864, Official Records, vol. 34:2, 928; Samuel Bell Maxey to S.S. Anderson, February 9, 1864, Official Records, vol. 34:2, 958; D.H. Cooper to Samuel Bell Maxey, February [?], 1864, Official Records, vol. 34:2, 959; Chief Moty Kanard to Samuel Bell Maxey, February 6, 1864, Official Records 34:2, 960.

412 Allan C. Ashcroft, "Confederate Indian Troop Conditions in 1864," Chronicles of Oklahoma 41, no. 4 (Winter, 1963): 442-444. 
drive away and destroy the rebels...I ask you to make your footsteps severe and terrible." To the Creek soldiers of the Indian Home Guard regiments, he offered a few special words of motivation. "Muscogees! the time has now come when you are to remember the authors of all your sufferings; those who started a needless and wicked war, who drove you from your homes, who robbed you of your property. Stand by me faithfully and we will soon have peace.” On February 1, the same day that tribal leaders met at Armstrong Academy to discuss their place within the Confederacy, Phillips's blue-clad troopers splashed across the Arkansas River and rode south to strike at the enemy. ${ }^{413}$

Building upon the successes of the summer previous, Colonel Phillip's raid was meant to extend Union authority into southern Indian Territory for the first time since the start of the war. Phillips hoped the sudden appearance of Union forces in Choctaw and Chickasaw Nations would spark "a moral effect on the Indian nations" and encourage rebellious Indians to return to the Union fold, just as many Cherokees had defected in 1862. Over the course of February, Phillips's raiders penetrated deep across southern Indian Territory, wreaking havoc and letting the Chickasaws and Choctaws feel the sting of war. ${ }^{414}$

The Union raiders adopted a stick and carrot approach as they entered enemy territory. With a mixed force of the $1^{\text {st }}$ and $3^{\text {rd }}$ Indian Home Guard, $14^{\text {th }}$ Kansas Cavalry, and a battery of howitzers, Colonel Phillips's force drove south into Creek Nation, "sweeping the whole valley of the upper Canadian and its tributaries north and south." The Federals made their presence felt, stripping an already meager countryside of corn and livestock. Just days into the raid, Colonel Phillips promised "I shall leave no secesh in the country," and his command carried out his

\footnotetext{
${ }^{413}$ William A. Phillips, circular, January 30, 1864, Official Records, vol. 34:2, 190; "Itinerary of the Indian Brigade," Official Records, vol. 34:1, 111-112.

${ }^{414}$ William A. Phillips to Samuel R. Curtis, February 24, 1864, Official Records, vol. 34:1, 108-109.
} 
prophecy with alacrity. The raiders ousted secessionist Indians from their homes, turning Rebels into refugees and prompting Phillips to declare "secessionism is about wiped out." The home of Chickasaw Governor Winchester Colbert was burned down, and the frightened governor fled south into Texas. As the Federals swept south, they met only scattered resistance, inflicting approximately 125 casualties in small skirmishes with the enemy. Yet rumors warned Phillips that Confederate forces were gathering at Boggy Depot, "which I rather like," Phillips determined, "as I would rather fight them there than hunt them up." 415

As the Federals advanced, Confederate forces retreated. Though Phillips's command numbered less than 1,000 , the Rebels could not muster a force strong enough to stop them. Indeed, Confederate officers worried whether they could hold the department headquarters at Fort Towson or even prevent the Federals from striking into North Texas. On February 13, the expedition's lone significant engagement occurred at Middle Boggy Depot, where Union raiders clashed with a small contingent of Rebel Seminoles, Choctaws, and Chickasaws. The Confederates were "completely routed and pursued considerable distance," but it was not the decisive battle Phillips yearned for. Contributing to the grim nature of the raid, Confederates reported after the fight that Seminole bodies "were mutilated, their throats cut from ear to ear." These atrocities were reportedly carried out by the white soldiers of the $14^{\text {th }}$ Kansas Cavalry. ${ }^{416}$

${ }^{415}$ R.T. Thompson [Phillips's adjutant general] to Lt. Gallagher, February 5, 1864, Official Records, vol. 34:2, 249; William A. Phillips to Brig. General Thayer, February 8, 1864, Official Records, vol. 34:2, 272; S.B. Maxey to E. Kirby Smith, February 26, 1864, Official Records, vol. 34:2, 994-997; William A. Phillips to Samuel Curtis, February 24, 1864, Official Records, vol. 34:1, 108-109.

416 "Itinerary of the Indian Brigade," Official Records, vol. 34:1, 111-112; Henry E. McCulloch to E.P. Turner, February 15, 1864, Official Records, vol. 32:2, 969; S.B. Maxey to E. Kirby Smith, February 26, 1864, Official Records, vol. 32:2, 994-997. Relatively few details are known about the Battle of Middle Boggy Depot. There are no known official reports of the battle from either side, though some details can be gleaned from Union and Confederate communications. Not even the precise location of the battlefield is known. As usual, Confederate and Union casualty counts differed. Union authorities reported 49 Confederates left dead on the field; Confederate communications indicated at least 11 Seminole dead and 4 Choctaw and Chickasaws killed. The Seminole battalion was presumably led by Col. John Jumper, and the Choctaw and Chickasaw company led by a Captain Nail. 
While Phillips's raiders smashed Confederate support throughout the region by force, they also sought to induce wavering Native Americans to reconcile with the United States. This was not a forlorn fantasy. At the war's outset, Creeks and Seminoles quickly divided over the issue of a Confederate alliance, with thousands ultimately seeking refuge in Union Kansas or enlisting in the Union Indian Home Guard. In 1862, Cherokees splintered upon the arrival of the Union army, and Chief John Ross and thousands of other Cherokees defected from Confederate ranks. Although the Choctaws and Chickasaws had remained loyal to the Confederacy through 1864, it was unclear whether this loyalty was born of strongly held Confederate sentiment or the reality of being firmly in Confederate occupied territory. Phillips hoped the Union army could further weaken Confederate-Indian relationships.

To this end, Colonel Phillips carried copies of Abraham Lincoln's Proclamation of Amnesty and Reconstruction, translated into Indian languages. Issued on December 8, 1863, the proclamation offered amnesty to any who had raised arms against the government. Phillips paired the proclamation with personal messages sent to Chickasaw Governor Winchester Colbert, Chief John Jumper of the Seminoles, and the Choctaw General Council. In his letters, Phillips asked these tribes to return to U.S. allegiance, predicting a swift end to the war and warning of the consequences of continued resistance. "The President has issued a proclamation in which he offers pardons and peace to those who, even in this moment of its destruction, abandon this wicked and unnecessary war," Phillips wrote to Governor Colbert. "You cannot fail to see the end coming? Are you justified in shutting the eyes of your people to it? The offer now made may never come back to you if neglected," Phillips warned. "The great Government of the United States will soon crush all the enemies. Let me know if you want to be among them." ${ }^{\$ 17}$

\footnotetext{
417 William A. Phillips to Samuel Curtis, February 16, 1864, Official Records, vol. 34:1, 106-108; William A. Phillips to Samuel Curtis, February 24, 1864, Official Records, vol. 34:1, 108-109; William A. Phillips to
} 
These letters failed to sway the tribal governments; they also came too late. By the time Phillips's missives reached the chiefs, the Confederate Indians had already met with General Maxey and reaffirmed their loyalty to the Confederacy at Armstrong Academy just days before. Although Native American support for the Confederacy had undoubtedly weakened over the course of the war, among the Choctaws and Chickasaws, it ultimately did not break. It's also probable that these tribes hoped to avoid the destructive intra-tribal violence that had plagued their Cherokee, Creek, and Seminole neighbors. Instead of prompting mass defection, most of Phillips's letters were simply handed over to Confederate authorities. ${ }^{418}$

Although most Choctaws and Chickasaws stayed true to their Southern alliances, a few dissident Choctaws did attempt to go over to the Federal side. Setting up a provisional government and selecting Thomas Edwards for governor, the Choctaws resolved "that our primary allegiance is due to the Government of the United States." In a proclamation, Edwards pointed out the failures of the Confederacy. "Three years of strife and misery, should at least convince you that the unnatural alliance which you have formed with the enemies of the United States has been one of the heaviest calamities to befell your Nation. They made you brilliant promises, but never fulfilled them." Edwards called for a "quick and speedy return" to U.S. allegiance. Though Edwards words reflected Phillips's hopes, the dissident Choctaw government were minority renegades. Most Choctaw leaders remained in opposition to the Union, and Phillips refused to recognize Edwards and his defectors as a legitimate government. ${ }^{419}$

Governor Colbert, February 15, 1864, Official Records, vol. 34:1, 109-110; William A. Phillips to Council of the Choctaw Nation, February 15, 1864, Official Records, vol. 34:1, 110; William A. Phillips to Chief John Jumper, February 15, 1864, Official Records, vol. 34:1, 111; S.B. Maxey to E. Kirby Smith, February 26, 1864, Official Records, vol. 32:2, 994-997; Ernest F. Darling, "Lincoln's Message to Indian Territory," Chronicles of Oklahoma 63, no. 2 (1985), 188-189.

${ }^{418}$ Angie Debo, Rise and Fall of the Choctaw Republic, 83-84; Samuel Bell Maxey to Edmund Kirby Smith, February 26, 1864, Official Records, vol. 32:2, 994-997.

${ }^{419}$ Debo, Rise and Fall of the Choctaw Republic, 83-84; Choctaw proclamation and Thomas Edwards quoted in Annie Heloise Abel, The American Indian and the End of the Confederacy, 1863-1866 (1925, repr.; 
Colonel Phillips's decision was perhaps also influenced by his communications with his superior officer, Major General Samuel Ryan Curtis (the victor of Pea Ridge). Kept appraised of Phillips's actions, Curtis praised the commander for his boldness. Yet he also made clear that Phillips did not have permission "to offer terms of peace to rebels that imply a relinquishment of legitimate forfeitures. The Choctaw Nation has clearly forfeited all right of property in the vast domain we will have to protect." Curtis and the United States sought to teach the rebellious Choctaws a lesson, "to understand that what they hereafter receive is on the score of humility and generosity." Yet the United States also had expansion and material rights in mind. Curtis waxed about the "vast resources of the Indian Territories," and thought "in the convulsions of the times try to improve the political institutions of these Indian nations to their own good and the national prosperity." Curtis' orders to Phillips reflected the $19^{\text {th }}$-century American belief that Native Americans needed white help in "civilizing" themselves. But Curtis' words also hinted at the United States' desire to lay claim to the material wealth of Indian Territory, and the Choctaws' allegiance to the Confederacy could serve as the legal underpinning to renegotiate those claims. ${ }^{420}$

Colonel William Phillips's February raid ultimately met with mixed results. Militarily, Federal forces stripped the landscape of supplies, scattered small Confederate commands, routed Confederate forces at Middle Boggy Depot, and generally demonstrated the inability of the Confederacy to protect the region between the Arkansas and Red Rivers. Yet this show of military force did not recreate the mass Native defections of 1862. The Choctaw and Chickasaw

Lincoln: University of Nebraska Press, 1993), 15-22. The dissident Choctaws met at New Hope Academy near Scullyville, whose proximity to the Union garrison at Fort Smith afforded them a degree of protection.

${ }^{420}$ Samuel R. Curtis to William A. Phillips, February 11, 1864, Official Records, vol. 34:2, 301-302; William A. Philips to Samuel R. Curtis, February 29, 1864, Official Records, vol. 34:2, 467-468. Upon receiving Curtis' instructions, Phillips responded affirmatively in late February, agreeing that "it is not now desirable to get back the Choctaws with their rights as a people," and promising "to sweep their nation with fire and sword so as to terrify and drive out al that would not at once yield in an abject peace." 
governments rebuffed Federal overtures and reaffirmed their Confederate allegiances, despite their wariness towards Confederate pledges of aid. Those Choctaws that did signal their desire to return to United States allegiance were too few to gain legitimacy. Moreover, attitudes towards the Choctaws had hardened among the Union high command, who were already looking ahead to renegotiated treaties that would further benefit the United States.

While fighting in Indian Territory sputtered to a standstill, the war in the TransMississippi slowly built to a violent climax just a few hundred miles east. By 1864, the Confederacy had reached a breaking point. The South's reserves of manpower were nearly exhausted, and Confederate transportation and logistical systems stretched thin. Hoping to exploit the South's deficit in men and material, newly appointed Ulysses S. Grant, commander of all United States forces, coordinated a series of offensives across the nation designed to finally break the Confederacy's back. The theory was simple: if pressure could be applied everywhere, the Confederacy would break somewhere.

In the Trans-Mississippi, the United States planned a two-pronged offensive along the Arkansas-Louisiana corridor. The main thrust would be carried out by Major General Nathaniel P. Banks and his Army of the Gulf. With nearly 30,000 men, Banks would strike out from Alexandria, Louisiana towards Shreveport, following the course of the Red River with an accompanying Union fleet in support. Banks' expedition had several goals: the capture of Shreveport, Confederate headquarters and a major Trans-Mississippi hub; the capture of muchneeded cotton for Northern mills; and opening a possible invasion route into East Texas, where Abraham Lincoln hoped to install a reconstructed state government among Unionists. 
While General Banks and the Army of the Gulf marched north through Louisiana, a secondary force under General Frederick Steele would march south from Little Rock. Moving through southern Arkansas, Steele could threaten Shreveport from the north, forcing the Confederates to split their already outnumbered forces. It was, in effect, a grand pincer movement: Banks sweeping up the Red River Valley from the south; Steele pushing through the piney woods of Arkansas from the north. Faced with large armies to their north and south, the Federals expected General Edmund Kirby Smith to simply evacuate.

Much to their chagrin, the Confederates instead elected to fight. The Federal Red River Campaign was a bloody disaster, a rare triumph for Confederate forces west of the Mississippi. On April 7-8, General Richard Taylor led Confederate forces to a pair of strategic victories at Mansfield and Pleasant Hill just south of Shreveport. At a high cost to both sides, General Taylor battered and bruised his Union counterpart, severely shaking General Banks' confidence and ultimately sending the Federals into a headlong retreat down the Red River. ${ }^{421}$

While Nathanial Banks met disaster south of Shreveport, Frederick Steele's expedition in Arkansas fared little better. Leaving Little Rock with 10,400 men in late March, Steele found his advance opposed by pestilent Confederate cavalry. Unable to confront Steele directly, Confederate General Sterling Price instead relied on his five brigades of cavalry to slow Steele's advance and strike at his supply lines. Searching for more troops, Sterling Price requested aid from Samuel Maxey, a request supported by Edmund Kirby Smith. Maxey immediately sent his Texan cavalry brigade under Brigadier General Richard Gano to Price’s aid. ${ }^{422}$

421 The Red River Campaign has drawn the attention of many scholars. The classic treatment is Ludwell $\mathrm{H}$. Johnson, Red River Campaign: Politics \& Cotton in the Civil War (1958; repr., Kent, OH: Kent State University Press, 1996).

422 Johnson, Red River Campaign, 170-179. Johnson's Red River Campaign contains several chapters that give a brief overview of the corollary Camden Expedition. The classic treatment of the Expedition is Edwin C. Bearss' Steele's Retreat from Camden \& the Battle of Jenkins' Ferry, which is heavily reliant upon the Official Records and a few published accounts. The modern standard is Michael J. Forsyth's The Camden Expedition of 
Yet Maxey also ordered Tandy Walker's brigade of Choctaws towards the Arkansas line. "Walker is a sensible man," Maxey reported, "and I think will exert himself to take the brigade where it may be needed, notwithstanding they are not required by the treaty to leave the Territory." General Maxey's order was an adroit one. He respected the Confederate-Indian treaties and did not order Walker to Price's aid, but by sending the Choctaws to the Arkansas line, he made the support available and left Walker with an obvious decision. Walker's Choctaws joined Gano's Texans, and Maxey himself elected to head to Arkansas to take command of his two-brigade division there. ${ }^{423}$

Despite their recent arrival, Maxey's Texan and Indians soldiers quickly found themselves in the midst of the fray. General Gano's Texas cavalry skirmished with Federal forces around Prairie d'Ane the first week of April, part of a wider Confederate effort to slow Steele's advance. Yet Steele's larger forces continued to bully their way south, and on the evening of April 14 ${ }^{\text {th }}$, Federal forces occupied Camden, Arkansas in the southern part of the state. The second largest town in Arkansas, Camden served as Steele's base over the coming weeks. It was also as far south as his ill-fated expedition got. With no direct supply line to Little Rock, the Union army grew hungry, and Steele was forced to resort to sending large supply trains into the surrounding countryside to forage for food. Echoing the Federals' precarious position at Fort Gibson the summer prior, Confederate forces targeted these supply trains as a means to starve Steele into submission or retreat. In effect, Camden was besieged. ${ }^{424}$

1864. See Edwin C. Bearss, Steele's Retreat from Camden \& the Battle of Jenkins' Ferry (1966; repr., Little Rock: Eagle Press, 1990); Michael J. Forsyth, The Camden Expedition of 1864 \& the Opportunity Lost by the Confederacy to Change the Civil War (Jefferson, NC: McFarland, 2003).

423 Johnson, Red River Campaign, 170-179; Samuel Bell Maxey to Edmund Kirby Smith, April 3, 1864, Official Records, vol. 34:3, 728-729.

${ }^{424}$ Waugh, Sam Bell Maxey and the Confederate Indians, 55-56; Johnson, Red River Campaign, 176-180. 
On April 18, General Maxey's two brigades (numbering a paltry 1,335 men) joined General John Sappington Marmaduke in a planned ambush of a Union supply train at the crossroads of Poison Spring, Arkansas. Arriving late to the scene, Maxey humbly deferred to Marmaduke's leadership in the coming fight, despite Maxey's seniority as general. Marmaduke's plan called for Maxey's two brigades to make a pinning attack from the south. Once the Federals were engaged, Marmaduke's force would strike the Federals from the east. If all went well, the 1,169 man Federal escort would be overwhelmed, and the 198 wagons would fall into Rebel hands. Among the Union escort were over 400 men of the First Kansas Colored Infantry, who had clashed with Maxey's Texans at Honey Springs the prior summer. ${ }^{425}$

The Confederate assault succeeded spectacularly. Maxey's forces engaged the Federals in a fierce firefight. The Texan regiments, led by Colonel Charles DeMorse of the $29^{\text {th }}$ Texas, anchored Maxey's right during the battle and clashed with the Federals in the thickest of the fray, "fighting as Texans know how to fight." Their ferocity was fueled by a realization that the African-American soldiers opposing them were the First Kansas Colored. In a destructive moment of déjà vu, Texan cavalrymen and black Federals repeated their bloody performance at Honey Springs in the piney hills of southern Arkansas. Eager for revenge, DeMorse's troopers cried out, "You First Kansas Niggers now buck to the Twenty-ninth Texas."

Col. Tandy Walker's twin Choctaw and Chickasaw regiments supported the Texans from the left, engaging the $18^{\text {th }}$ Iowa Cavalry who had taken position in a wooded ravine. The Iowans were rattled by the war whoops of the Choctaws, "a demoniac yell" as one Iowan captain

\footnotetext{
${ }^{425}$ Gregory J.W. Urwin, "Poison Spring and Jenkins' Ferry: Racial Atrocities during the Camden Expedition," in "All Cut to Pieces and Gone to Hell": The Civil War, Race Relations, and the Battle of Poison Spring, edited by Mark K. Christ (Little Rock: August House, 2003), 110-114. The Texan brigade consisted of the $29^{\text {th }}, 30^{\text {th }}$, and $31^{\text {st }}$ Texas Cavalry, along with Krumbhaar's Texas battery of four guns. The Choctaw brigade consisted of the $1^{\text {st }}$ and $2^{\text {nd }}$ Choctaw and Chickasaw Mounted Rifles.

${ }^{426}$ Urwin, "Poison Spring," 114-124; "Report of Brig. Gen. Samuel B. Maxey,” April 23, 1864, Official Records, vol. 34:1, 841-844; Britton, Union Indian Brigade, 367.
} 
recalled. Walker ordered his men to charge the position, and the Indians swept forward with "a courage on the part of officers and men well becoming an army of veterans." As DeMorse's Texans and Walker's Indians slammed repeatedly into the Federal line, Marmaduke's Arkansas brigades finally arrived from the east to seal the Federals' fate. Last ditch attempts to defend the train and allow the wounded to escape failed, and Confederate forces swept over the train and routed the blue-clad defenders. Among the Iowans, the retreat was hastened by the fear that "the Indians were not far away." 427

As Maxey's soldiers swept forward, the glow of victory quickly devolved into the butchery of massacre. Texan cavalrymen, recalling their defeat at Honey Springs, took their vengeance upon the wounded black soldiers of the First Kansas Colored. Confederate soldiers executed wounded soldiers mercilessly, calling out "Where is the First Kansas Nigger now?" Others responded, "All cut to pieces and got to hell by management.” During the fight,

${ }^{427}$ Charles D. Lothrop, A History of the First Regiment Iowa Cavalry (Lyons, IA: Beers \& Eaton, 1890), 181-182; "Report of Brig. Gen. Samuel B. Maxey," April 23, 1864, Official Records, vol. 34:1, 841-844; "Report of Col. Tandy Walker," April 19, 1864, Official Records, vol. 34:1, 849; "Report of Col. Charles DeMorse," April 21, 1864, Official Records, vol. 34:1, 846-848; William Franklin Avera, "Extracts from the Memoirs of William Franklin Avera," edited by Henry Cathey, Arkansas Historical Quarterly 22, no. 2 (Summer, 1963), 102-103; Urwin, "Poison Spring," 118-123; Forsyth, The Camden Expedition of 1864, 112-117. Accounts (and thus historians) differ on the Choctaws' military performance at Poison Spring. Confederate reports by Samuel Bell Maxey, Charles DeMorse, and Tandy Walker all lauded the Choctaws and Chickasaws for doing their duty. Walker specifically praised his men's ability to move past the alluring wagon train and keep up a hot pursuit of the foe. Of course, it was certainly in Walker's and Maxey's interests to praise their troops. DeMorse reported, "The Choctaws, who, from their position flanking nearly to the enemy's rear, were better enabled to purse them advantageously, continued keenly on their track and did splendid service." Given his racial condescension towards Native Americans, DeMorse's report is perhaps the most compelling bit of evidence in the Choctaws' favor.

Yet several post-battle accounts suggested the Choctaws were indecisive and easily distracted by the wagon train. In 1886, Captain W.C. Rowland of the $18^{\text {th }}$ Iowa (cited in Lothrop) recounted that the Choctaws "could not ride the steep ravine, and having no discipline, they gave the 'war whoop' - a demoniac yell—and broke for the plunder of the train. This disconcerted the Rebels and saved the Eighteenth." Though not present at the engagement, Private William Alvera of the $5^{\text {th }}$ Arkansas Field Battery heard the Choctaws "were worth but little, but to plunder the captured wagons." Given the differences in sources, historians have taken various stances. Michael Forsyth suggests the Choctaws carried their weight, although he largely references the Choctaws and Texans together at the divisional level. By contrast, Gregory Urwin contends the Choctaws were largely kept at bay by their Iowan counterparts, whom the Choctaws outnumbered and outflanked, and looted the train rather than pursuing their Union foes. It's worth noting the Choctaw regiments suffered 4 killed, 7 wounded, while the Texans suffered 3 killed, 28 wounded. 
Lieutenant William Murphy Cravens, a white Arkansan serving as adjutant to the Choctaws, reported to his wife, "We fought one African Regiment, and I got me a likely boy about 15 years-old." Giving the enslaved boy to a Choctaw man "to keep when the fight was over," the Choctaw reported "the boy was dead: 'White man shoot him up." As Rebels roamed the dead, terrified black soldiers played dead, enduring the pain of their wounds and discomfort of wildlife in hopes of surviving until nightfall. ${ }^{428}$

In the midst of the massacre were the Choctaws and Chickasaws of Tandy Walker's brigade. Scalping and stripping the dead, the Choctaws left quite an impression on observers. "You ought to see Indians fight Negroes—-kill and scalp them," recalled Arkansan trooper Charles Anderson. "Let me tell you, I never expected to see as many dead Negroes again. They were so thick you could walk on them." Private Charles Pidcocke of the $30^{\text {th }}$ Texas Cavalry wrote approvingly of the affair. "The Indians were turned loose just about the time our brigade had them whipped. Gentlemen of the colored race suffered. The Choctaws killed every nigger and stripped everything both black and white...This slaughter of the darkies may seem inhumane to some people," Pidcocke allowed," but I for one cry bully for the Choctaws....I no longer wonder that the war in Arkansas is war with the knife." Killing and scalping the dead wasn't enough in once instance. After burying a white Union soldier, the Choctaws buried a pair of

${ }^{428}$ Britton, Union Indian Brigade, 372-373; Urwin, "Poison Spring," 124-127; Henry A. Strong, "A Rough Introduction to This Sunny Land": The Civil War Diary of Private Henry A. Strong, Co. K, Twelfth Kansas Infantry, edited by Tom Wing (Little Rock: Butler Center for Arkansas Studies, 2006), 41-42; Joseph Frankovic, et. al., "Prairie D'Ane and Poison Spring from a Southern Perspective," Journal of the Fort Smith Historical Society 31:1 (April, 2007), 36-44. The $1^{\text {st }}$ Kansas Colored suffered 39\% casualties at Poison Spring; casualties were heavy even among companies that managed to escape. See Ian Michael Spurgeon, Soldiers in the Army of Freedom: The $1^{\text {st }}$ Kansas Colored, the Civil War's First African American Combat Unit (Norman: University of Oklahoma Press), 218-219; John R. Graton to Adelaide Graton, April 21, 1864, John R. Graton Letters, BCAR. 
black Union soldiers vertically to serve as a grim headstone and footstone. Those who weren't slaughtering the wounded pilfered the wagon train for much-needed goods. ${ }^{429}$

Word of the Indians' brutality spread quickly. Just days later, Confederate artilleryman William Avera got "my first and only opportunity to see Genl Maxeys Indians." He thought them "a tough looking lot," decked out in buckskin, feathers, with many toting multiple guns. Yet Avera had heard "they were worth little, but to plunder the captured wagons" and that the Indians "were anxious to scalp the killed negroes." As Federal wounded and stragglers escaped and made their way back to Union lines, news of the massacre likewise accompanied them. Private Henry Strong of the $12^{\text {th }}$ Kansas Infantry scribbled in his diary "the Rebels killed all the darkies that fell into their hands," including those attempting to surrender. These rumors undoubtedly grew when a Union burial party returned to Poison Spring a few days after the fight. "The white dead were scalped and all were stripped of clothing, which was worn by the rebels," an Iowa captain recalled. "To add insult to the dead officers of the colored regiment, they were laid on their faces and a circle of their dead soldiers made around them." ${ }^{\prime 430}$

Thoroughly documented both then and now, historians have offered various explanations for the racial atrocity at Poison Spring. Dismissing Confederate explanations that the atrocity stemmed from Federal plundering, Gregory Urwin convincingly argues “the perpetrators' motives were racial." Angered and threatened by emancipation and Union enlistment of AfricanAmericans (many of whom were runaway slaves), while likewise viewing armed black soldiers as servile insurrection, Southerners believed the execution of black soldiers justified and

${ }^{429}$ C.T. Anderson, "Campaigning in Southern Arkansas: A Memoir by C.T. Anderson," edited by Roman J. Zorn, Arkansas Historical Quarterly 8, no. 3 (Autumn, 1949), 242-243; Charles H. Pidcocke to Robert Storm, May 15, 1864, C.H. Pidcocke Civil War Letter, BCAR; Urwin, "Poison Spring," 125.

${ }^{430}$ Avera, "Extracts from the Memoirs of William Franklin Avera," 102-103; Strong, "A Rough Introduction to This Sunny Land", 41; Lathrop, History of the First Regiment Iowa Cavalry, 182. 
necessary. Anne Bailey has also pointed out the Texan troops present were not known for their discipline, an argument which could extend to the unruly Choctaws as well. Finally, the prior defeat inflicted upon the $29^{\text {th }}$ Texas and Confederate forces at Honey Springs added a regimental feud which further exacerbated the situation. ${ }^{431}$

While these explanations all have merit, to understand the Choctaws' role in the massacre of Poison Spring, Arkansas, one must also recall the events of the prior two months in Indian Territory. For the Choctaws and Chickasaws, the fight at Poison Spring offered a chance to avenge Colonel Phillips's February expedition. Just weeks prior to the battle, Choctaw and Chickasaw Nations were touched for the first time by Federal raiders, who plundered crops, livestock, burned homes, and reportedly mutilated Indian bodies. Having strewn mayhem, Phillips's raiders then escaped unscathed. These outrages were fresh upon the minds of Tandy Walker's Choctaws and Chickasaws on the eve of battle. Colonel Walker reported his men "met and routed the [enemy], the ravagers of their country, the despoilers of their homes, and the murderers of their women and children." General Maxey echoed these sentiments in his own report, noting the Choctaws "fought the very army (Thayer's, from Fort Smith), that had destroyed their once happy homes, insulted their women, and driven them with their children destitute upon the world, and many an avenging blow was struck." For the Choctaws and Chickasaws, the killing of Union soldiers at Poison Spring was in part motivated by a desire for revenge. $^{432}$

${ }^{431}$ Gregory J.W. Urwin, “We Cannot Treat Negroes...as Prisoners of War"”: Racial Atrocities and Reprisals in Civil War Arkansas" in Civil War Arkansas: Beyond Battles and Leaders, edited by Anne J. Bailey and Daniel E. Sutherland (Fayetteville: University of Arkansas Press, 2000), 220; Anne J. Bailey, "Was There a Massacre at Poison Springs?", Military History of the Southwest 20, no. 2 (Fall, 1990), 164; Urwin, "Poison Spring," 125-128, Also see Black Flag Over Dixie: Racial Atrocities and Reprisals in the Civil War, edited by Gregory J.W. Urwin (Carbondale: Southern Illinois University Press, 2005).

432 "Report of Colonel Tandy Walker," Official Records vol. 34:1, 849; "Report of Brig. Gen. Samuel B. Maxey," Official Records, vol. 34:1, 843. 
Regardless of motivation, the massacre of black soldiers at Poison Spring went ignored by Confederate officers and generals. Neither General Maxey nor his two brigade commanders made any mention of it in their official reports. Indeed, Maxey's reputation soared following the victory, and he showered praise on his soldiers, including the Choctaws, for whom he predicted the victory "will adorn the brightest pages in the national history of the Choctaws." Biographers of Maxey likewise avoid mention of the post-battle slaughter. Such silence in unacceptable. Samuel Bell Maxey bore direct responsibility for his troops' actions at Poison Spring. His men, both DeMorse's Texans and Walker's Choctaws and Chickasaws, appear to have been the primary instigators of the slaughter. The inability or unwillingness of Maxey, DeMorse, Walker, and other Confederate officers to halt the massacre speaks to their condoning of it. ${ }^{433}$

In the wake of Poison Spring, Maxey's division returned to Indian Territory. Maxey's contribution to the victory earned him a promotion to major general, and once again the Texan commander turned his attention back to ousting the Federals from Indian Territory.

The steamboat ferry slowly chugged along the high waters of the Arkansas River, having left Fort Smith earlier in the day and bound for the Union garrison at Fort Gibson. The boat was laden with sundry goods: hundreds of barrels of flour, thousands of pounds of bacon, 20 sacks of much treasured green coffee, brown sugar, and other quartermaster's stores. Upon dropping off the goods to the hungry Federal troopers at the fort, the J.R. Williams would load up on vital salt and lime and make the return trip down the Arkansas to Fort Smith. To guard these supplies, the Union commander at Fort Smith—General John Thayer-sent along 26 men of the $12^{\text {th }}$ Kansas

${ }^{433}$ Biographers Nancy Hobson, Louise Horton, and John Waugh make no mention of the massacre after the fight at Poison Springs. Given the wealth of both wartime and secondary sources (including several that predate publication of the biographers' works) that speak to the massacre, the omission seems sloppy or purposeful. See Hobson, "Samuel Bell Maxey," 101; Horton, Samuel Bell Maxey, 38; Waugh, Sam Bell Maxey, 58-61. 
Infantry, led by Second Lieutenant Horace Cook. Enjoying the steamboat ride was Private Henry Albert Strong, a young gray-eyed farmer from Mound City, Kansas. Also onboard was Lieutenant Huston, a quartermaster for the $14^{\text {th }}$ Kansas Cavalry returning to his unit. ${ }^{434}$

Around four in the afternoon on June 15, 1864, approximately 50 miles from Fort Smith, the J.R. Williams rounded the bend at Pheasant Bluff on the river. Unbeknownst to the ship's crew and the Union escort, perched atop the bluff were three artillery pieces. They had been carefully positioned and camouflaged with brush by twenty-one year old Captain George Washington Grayson of the $2^{\text {nd }}$ Creek Regiment. Alongside Grayson atop the bluff were hundreds of Cherokees, Creeks, and Seminoles under the command of Colonel Stand Watie. Knowing the Arkansas' waters were rising, Watie's men had laid the ambushed days before, patiently waiting for prey to arrive. As the Williams paddled into view, their prey had arrived. ${ }^{435}$

The Confederates fired a single shot over the Williams' bow as a warning. When the boat refused, the Rebel troopers "opened up on him in fine style and soon filled the air with the roar of cannon and rattle of small arms." Posted up on the hurricane deck, Henry Strong ran below to grab his rifle to try and defend the steamboat. Faced with three artillery pieces and hundreds of foes, however, the J.R. Williams and its small Federal escort stood little chance. Confederate artillery carved into the ship, and with just a few rounds, the Williams' engineer and fireman were killed and its boiler punctured. Heavily outnumbered, the handful of Kansan infantrymen made a brief, valiant, but futile defense. Henry Strong and his comrades hid "behind the freight

${ }^{434}$ John M. Thayer to Frederick Steele, June 22, 1864, Official Records, vol. 34:4, 503-504; George W. Hutton to Greene Durbin, June 14, 1864, Official Records, vol. 34:4, 687; G.L. Gaylord to M.S. Adams, June 14, 1864, Official Records, vol. 34:4, 687; "Reports of Col. Stand Watie," June 17 and June 27, 1864, Official Records, vol. 34:1, 1012-1013; Strong, "A Rough Introduction to This Sunny Land”, xvii-xviii, 51.

${ }^{435}$ Strong, "A Rough Introduction to This Sunny Land", 51; John M. Thayer to Frederick Steele, June 22, 1864, Official Records, vol. 34:4, 503-504; "Reports of Col. Stand Watie," June 17 and June 27, 1864, Official Records, vol. 34:1, 1012-1013; Grayson, A Creek Warrior for the Confederacy, 81-82. The bend is also known as Pleasant Bluff. 
and returned the fire to the best advantage we could." On the southern bank, Captain Grayson recalled the enemy "fired one volley without effect." While the Federals tried to make a firefight of it, the desperate pilot cleverly steered the ship towards the northern bank of the Arkansas River. $^{436}$

Realizing the futility of their situation and with a plausible means of escape, Lieutenant Cook ordered his infantrymen to bail and dash for the treeline on the northern bank. Cook, Strong, and his mates “all jumped overboard, water waist deep and waded ashore.” It was a long forty yards to the treeline, and the Confederates "kept up a most terrific fire," but only two Federals were lightly wounded. With the ship damaged and its Federal escort fled, the Williams' captain and pilot raised a white flag from the pilot house. Also onboard was Lieutenant Huston, who apparently hid below decks during the fight and now jumped at the chance to surrender. Watching from the northern shore, Lieutenant Cook and his men had hoped to use their rifles to keep the Rebels at bay from the ship. To their dismay, they watched as Confederates took possession of the surrendered boat and floated her towards the southern shore. Unable to do more, Cook, Strong, and the Kansans spent a long, hungry day making their way back to Fort Smith overland. ${ }^{437}$

The Confederates were overjoyed with their captured loot. Col. Watie appointed a guard and set to work moving the captured goods to the shore. Having faced material shortages nearly the entire war, discipline broke down among the Rebel raiders when faced with such a plethora of goods: bacon, hominy, salt pork, flour, brown sugar, coffee, tin cups, and more. Watie

${ }^{436}$ Grayson, Creek Warrior, 82-83; Strong, "A Rough Introduction to This Sunny Land”, 51-52; John M. Thayer to Frederick Steele, June 22, 1864, Official Records, vol. 34:4, 503-504; "Reports of Col. Stand Watie," June 17 and June 27, 1864, Official Records, vol. 34:1, 1012-1013.

${ }^{437}$ Strong, "A Rough Introduction to This Sunny Land", 51-52; Grayson, Creek Warrior, 82-83; Thayer to Frederick Steele, June 22, 1864, Official Records, vol. 34:4, 503-504; "Reports of Col. Stand Watie," June 17 and June 27, 1864, Official Records, vol. 34:1, 1012-1013. 
lamented that the "Creeks and Seminoles immediately broke off to carry their booty home."

Worse than the erosion of discipline, Watie had no means to immediately transport the goods; there were no wagons and the roads were in "wretched condition." Ironically, when presented with a sudden opportunity to mitigate their woeful supplies, the Confederates didn't have the logistical capability to move it. And it would only be so long before the Federals returned.

The following afternoon, Lieutenant Cook, Private Strong, and the Kansans wearily arrived at Fort Smith and reported the disastrous capture of the J.R. Williams. Angry, General Thayer dispatched the $2^{\text {nd }}$ Indian Home Guard from that place, and on the morning of June $17^{\text {th }}$ the Indians reached the north bank of Arkansas, opposite the wrecked Williams and the Confederate camp. A frustrated Watie couldn't afford to fight the Federals with his meager numbers, but also lacked the ability to carry the goods away. Captain Washington outlined Watie's predicament: "Here we were only a scout of some fifteen hundred men far away from our base, with light artillery of great value to our army. To jeopardize this as well as other interests only in the hope of saving a quantity of hominy and salt pork was not wise military judgement." Watie ordered his soldiers to take all they could carry, and the remainder was set alight. The Federals pursued briefly, but were checked. Content with forcing Watie to abandon the loot, they retreated back towards Fort Smith. ${ }^{438}$

The attack on the J.R. Williams marked the first clash in Confederate efforts to retake control of the Arkansas River Valley in the summer of 1864. Like his predecessors, Maxey understood the "true defense of this Territory, and consequently of Northern Texas, was north of

${ }^{438}$ Strong, “A Rough Introduction to This Sunny Land”, 52; John M. Thayer to Frederick Steele, June 22, 1864, Official Records, vol. 34:4, 503-504; "Reports of Col. Stand Watie," June 17 and June 27, 1864, Official Records, vol. 34:1, 1012-1013; Grayson, A Creek Warrior, 83-84. Watie had hoped reinforcements might arrive, but the high waters of the Canadian River to his south prevented Chickasaw reinforcements from arriving in a timely manner. When they did arrive, Watie sent 150 of them towards the bridge at San Bois, where he suspected the Federals might cross. This is where the $2^{\text {nd }}$ Indian clashed briefly with the Confederates, using artillery to force the Rebels back. But the delaying action allowed Watie to get away, the Federals retreated. 
the Arkansas River.” Although Phillips's Expedition and the Red River Campaign delayed his campaign, he believed it vital to retake Fort Gibson and Fort Smith. To do this, Maxey identified the same weakness that General Steele had pinpointed in 1863: the weakness of Federal logistics. "The forces at Fort Gibson and Fort Smith must now depend to a great extent upon wagon trains," Maxey reported. "When the Arkansas rise, if the navigation of the river is left uninterrupted, they can get everything they want and lay in spring supplies." With the Federals holed up in their fortifications, striking the Federals' supply lines was the key to weakening and perhaps ousting the Union from Indian Territory. Although the navigable waters of the Arkansas did indeed offer a convenient means of resupply for Fort Gibson, Watie's attack on the J.R. Williams exposed the weakness of that water route and forced the Federals to once again rely on long and vulnerable supply trains to keep Fort Gibson's garrison supplied. ${ }^{439}$

The repulse of the General Steele's Camden Expedition and the destruction of the J.R. Williams bolstered Rebel morale and kept Federal forces on the defensive. As the summer wore on, Confederates searched for another opportunity to weaken Federal control in the region and perhaps wrest control of the Arkansas Valley from the Union's grasp. In late July, just such an opening presented itself. Douglas Cooper received reports of a Federal detachment of cavalry grazing on Massard Prairie, five miles south of Fort Smith. Away from the extensive fortifications of Fort Smith, 200 troopers of the $6^{\text {th }}$ Kansas Cavalry lay vulnerable to attack. Yet shortages of forage demanded that Yankee troopers graze their mounts outside the town's fortified lines. ${ }^{440}$

${ }^{439}$ Samuel Bell Maxey to S.S. Anderson, January 12, 1864, Official Records, vol. 34:2, 856-858.

440 "Report of Brig. Gen. Douglas H. Cooper," August 10, 1864, Official Records 41:1, 31-36; Frank Arey, "'The Place is Well Fortified': Massard Prairie and the Confederate Attack on Fort Smith, July 27 and 31, 1864," Journal of the Fort Smith Historical Society 27:1 (April, 2003), 3-9. Frank Arey's recent article offers an excellent 
Seizing his chance, Douglas Cooper quickly concocted a complex plan involving Indian and Texan troops attacking the Union forces from multiple approaches. General Richard Gano would lead the forces in the field. When Gano arrived in the vicinity, he discovered fewer Indian soldiers had arrived than expected. Scrapping Cooper's complicated battle plan, Gano elected instead for a simple, straightforward attack on the unsuspecting enemy. In the predawn hours of July 27, nearly 600 Confederate troopers gathered for an attack less than a mile south of Massard Prairie. $^{441}$

The Confederates struck at sunrise. Sweeping north, the mounted Rebels stormed into the Federal picket line. Although Union pickets quickly fired on the oncoming foes, they were driven back into the main camp almost immediately, affording almost no time for the Kansan troopers to gather their mounts. A hasty message asking for aid was sent to the nearby $14^{\text {th }}$ Kansas Cavalry (encamped some two miles away). Within minutes, the Confederates burst out of the southern timber line and swept forward into Massard Prairie. Unable to gather their mounts in time, Union troopers fought as infantry. Their commander, Captain David Mefford, managed to form the troopers into a battle line and attempted to drive off the Confederate host. Though severely outnumbered, the Yankee troopers toted Sharps carbines and revolvers, and their firepower checked the initial charges of the Rebels. Yet Confederates countered the Federal firepower by sweeping forward in brief charges, firing their guns, then retiring out of range of the enemy carbines. Captain Mefford kept up a valiant fighting retreat, falling back towards a

synopsis of Massard Prairie and the Confederate probe towards Fort Smith. See also Dale Cox, The Battle of Massard Prairie: The 1864 Confederate Attacks on Fort Smith, Arkansas (Bascom, FL: William Cox, 2008); Steve Cox, "The Action of Massard Prairie," Journal of the Fort Smith Historical Society 4:1 (April, 1980), 11-13; and Edwin C. Bearss, "General Cooper's CSA Indians Threaten Fort Smith,” Arkansas Historical Quarterly 26:3 (Autumn, 1967), 257-284.

${ }^{441}$ Confederate forces at Massard Prairie included the detachments from a variety of Texan and Indian cavalry units, including the $5^{\text {th }}$ Texas Partisan Rangers, $29^{\text {th }}$ Texas Cavalry, $30^{\text {th }}$ Texas Cavalry, $31^{\text {st }}$ Texas Cavalry, Wells' Texas battalion, $1{ }^{\text {st }}$ Choctaw Regiment, $2^{\text {nd }}$ Choctaw Regiment, and Colbert's Chickasaw battalion. 
house on the north side of the prairie. "The men behaved splendidly," one Kansan lieutenant recalled, "repulsing repeated charges of the enemy's cavalry, Captain Mefford doing all in his power to keep the men well in hand and stimulating them by his example." ${ }^{442}$

Yet Confederate numbers soon took their toll. Confederate troopers surrounded Captain Mefford's beleaguered command and chased down they few mounted Federals who attempted to escape northward. While the majority of the Confederate command kept up the attacks, others fell out to strip the dead of much-needed supplies. With no prospect of escape and no idea if the $14^{\text {th }}$ Kansas Cavalry was en route, Captain Mefford and the Kansans were forced to surrender. The $6^{\text {th }}$ Kansas Cavalry suffered 10 killed, 20 wounded, and at least 120 captured (including Captain Mefford). The Confederates suffered 7 or 8 killed and 26 wounded. ${ }^{443}$

Adding to the sweetness of their tidy little victory, Confederate troopers gathered a veritable fortune of small arms and supplies strewn across the prairie. The Rebels netted themselves 200 Sharps carbines and 400 revolvers. For haggard troopers who carried hunting rifles, shotguns, or infantry arms for much of the war, such arms were a delight. Besides firearms, the Rebels secured horses, sutler's stores, and other much needed equipment. One captured wagon contained the regimental flag and records of the $6^{\text {th }}$ Kansas. Lieutenant William Murphy Cravens of the Choctaw Regiment confided to his wife Mary, "Soldiers came back, especially the Choctaws, loaded with clothing and plunder of every kind. Guns, saddles, pistols, camp kettles, buckets, cups, blankets, hats, boots, and the ponys [sic] fairly groaned under their

442 "Report of Brig. Gen. Douglas H. Cooper," August 10, 1864, Official Records 41:1, 31-36; "Report of Lieut. Jacob Morehead," July 29, 1864, Official Records 41:1, 25; "Report of Lieut. Levi F. Stewart," August 2, 1864, Official Records 41:1, 25-26; "Report of Lieut. William Burgoyne," July 29, 1864, Official Records 53:1, 480-481; Arey, "“The Place Is Well Fortified"," 4-5.

443 "Report of Brig. Gen. John M. Thayer," July 30, 1864, Official Records 41:1, 23-24; "Reports of Maj. Gen. Samuel B. Maxey," July 30, 1864, Official Records, 41:1, 29; "Report of Brig. Gen. Douglas H. Cooper," August 10, 1864, Official Records 41:1, 31-36; "Report of Lieut. William Burgoyne," July 29, 1864, Official Records 53:1, 480-481. 
tremendous freightage which in bulk at least would often have exceeded the ponys themselves." What the Confederates couldn't keep, they burned. Douglas Cooper credited the "brilliant and dashing affair" to General Gano. ${ }^{444}$

Encouraged by their success at Massard Prairie, Confederate officers contemplated a more serious attack on Fort Smith. Yet the town and post of Fort Smith were ringed by wellengineered fortifications, including several strong forts along the southward Texas Road. As General John Thayer, Union commander of Fort Smith, crowed, "The place is impregnable...[with] a continuous line of rifle-pits, with an extensive abatis form the Arkansas around to the Poteau River." Thayer felt secure in his control of the Arkansas River Valley: "I have no fears as to this place [Fort Smith] or Gibson." Yet Thayer's garrison was not overly large, and if the Confederates could retake Fort Smith, it would leave the entire Arkansas River Valley (including Fort Gibson) vulnerable. ${ }^{445}$

Taking several days to gather a larger force, General Douglas Cooper advanced again towards Fort Smith on the morning of July 31. Douglas' force approached Fort Smith from the south and included Gano's Texas brigade, Stand Watie's Cherokee brigade, and Sampson Folsom's Choctaw brigade. While Cooper moved toward the city's southern defenses, Confederate Creeks demonstrated against the Federal earthworks near the Poteau River west of the city. ${ }^{446}$

444 "Reports of Maj. Gen. Samuel B. Maxey," July 30, 1864, Official Records, 41:1, 29; "Report of Lieut. William Burgoyne," July 29, 1864, Official Records 53:1, 480-481; Frankovic, et. al., "Prairie D’Ane," 63; William Murphy Cravens quoted in Cox, "The Action on Massard Prairie," 11-12; "Report of Brig. Gen. Douglas H. Cooper," August 10, 1864, Official Records 41:1, 31-36.

${ }^{445}$ John Thayer to Frederick Steele, May 28, 1864, Official Records 34:4, 84; "Report of Brig. Gen. John M. Thayer," July 30, 1864, Official Records 41:1, 23-24; Arey, “"The Place Is Well Fortified'," 3-4.

446 "Report of Brig. Gen. Douglas H. Cooper," August 10, 1864, Official Records 41:1, 31-36; Arey, “"The Place Is Well Fortified'," 6-7. 
In the vanguard, Stand Watie's Cherokees moved ahead long the Texas Road toward Fort Smith, with Texans and Choctaws in reserve. The Cherokees swept forward, running over picket outpost of the none other than the $6^{\text {th }}$ Kansas, who yet again found themselves bullied by a larger Confederate force. The Kansan troopers fell back towards Fort Smith's entrenchments, while Watie's troopers scoured the captured picket posts. Watie and his troopers enjoyed "a good dinner prepared and several camp kettles full of hot Lincoln coffee."

Both the Federals and Confederates began to consolidate their positions. Federal forces began to appear in larger numbers, while Douglas Cooper ordered the rest of his command up to Watie's support. With a two-gun battery in support, the Confederates pushed the Federals back and began shelling the city's fortifications. Yet the Federals continued to bring up more men, including the rest of the $6^{\text {th }}$ Kansas Cavalry and portions of the $1^{\text {st }}$ Kansas Colored Infantry. Also pulled forward were the Parrott rifles of the $2^{\text {nd }}$ Kansas Battery, whose range and accuracy far eclipsed the Confederates smoothbore howitzers. Countering the Confederate battery fire, a onesided artillery duel quickly silenced the Confederate guns. As Kansan Private Henry Strong noted, "Our batteries played them so lively that they had to retreat back out of range." The Confederate guns withdrew, and as the Federals shifted their artillery fire toward the Confederate troopers, the entire command retreated. The next day, Cooper withdrew his brigades back into Indian Territory. Though Cooper declared "a vigorous attack with the whole force, though doubtless it would have been attended with heavy loss on our side, I believe would have resulted in the capture of the place," his troopers were "tired and hungry," mounts were haggard, and the Choctaws enlistment was about to expire. Although Cooper hoped the Federals might evacuate

\footnotetext{
447 "Report of Brig. Gen. Douglas H. Cooper," August 10, 1864, Official Records 41:1, 31-36; Cravens quoted in Arey, "The Place Is Well Fortified"," 6-7.
} 
the fort on their own accord, they did not, and Cooper was satisfied the Fort Smith's defenses were too much to overcome. ${ }^{448}$

The Battle of Massard Prairie and the subsequent probe of Fort Smith represented the Confederacy's last serious attempt to retake control of the Arkansas River Valley. Massard Prairie and the fight at Fort Smith allowed the Rebels to capture or destroy a fair amount of supplies. The luckless $6^{\text {th }}$ Kansas Cavalry was likewise ravaged. Union citizens around Fort Smith, panicked by the burst of Confederate activity, flooded the city and created logistical nightmares for Federal officials. Yet the great prize — control of Fort Smith itself — eluded the Confederates. As long as the Arkansas River Valley and its bastions at Fort Gibson and Fort Smith remained in enemy hands, the Confederates had little strategic control over the region. ${ }^{449}$

Praised by Douglas Cooper for his service, General Richard Gano was instead privately frustrated with the whole affair. Having fought with cavalier John Hunt Morgan earlier in the war, Gano had grown "accustomed to a more efficient and exciting service" and felt dissatisfied with the ineptitude and tedium of service in Indian Territory. Writing a confidential letter to Samuel Maxey, Gano confided, "I had it in my power also to have exhausted and taken Fort Smith, if we had had forage \& water for our horses, but without forage and not allowed closely to invest, the marches to \& soon broke down our horses." Gano believed had the besieged the town and attacked enemy wagon trains, Fort Smith would've fallen. But the lack of Rebels' lack of supplies "was the great hindrance." Moreover, Gano expressed his lack of faith in the abilities

\footnotetext{
448 "Report of Brig. Gen. Douglas H. Cooper," August 10, 1864, Official Records 41:1, 31-36; Strong, “A Rough Introduction to This Sunny Land", 54; Arey, "The Place Is Well Fortified"," 7-8.

449 “Report of Brig. Gen. Douglas H. Cooper," August 10, 1864, Official Records 41:1, 31-36.
} 
of Confederate Indians units, sentiments which his men shared (although Gano never publicly revealed this opinion). He hoped to transfer out of Indian Territory. ${ }^{450}$

While Cooper and Gano's assertions that Fort Smith could have been taken are debatable, Gano's private frustrations reflected the discontent among Confederate officers and men alike at the constant failures within Indian Territory. His letter also reveals the doubts harbored by white soldiers as to the efficacy of their Indian allies. Somewhat ironically, however, Gano and his troopers were soon to experience one of the most daring and spectacular Confederate victories of the war.

However dour Richard Gano’s outlook on Indian Territory, it improved radically within a few weeks. "I feel in rather good humor today and some what hopeful, probably because there is a prospect for fish to day for dinner," Gano wrote to General Maxey, "but more likely...because you are going to send me an order to north of the Arkansas River, and do all the damage to the Yanks I can up there.” The good-natured, aggressive Kentuckian looked forward to the prospect of combat, confident that "Genl Stand Watie would cooperate with us... and I am satisfied some good opportunities have and are being presented. What say you?"451

General Gano was not alone in his desire to take the field. Stand Watie had likewise been agitating for some time to strike north. The timing of these commanders couldn't have been better. Within the wider Trans-Mississippi theater, Lieutenant General Edmund Kirby Smith had

${ }^{450}$ Richard Gano to Samuel Bell Maxey, August 20, 1864, Maxey Papers, HCAR, GI. Regarding Indianwhite relations among the ranks, Gano also noted that "the whites just after a fight feeling that others have not done their part, and then witnessing them make assault on wounded men, are so apt to become enraged and threaten violences." Gano's statement implies white resentment over Choctaw participation in the butchery of Poison Spring, an odd statement since white Texans were equally involved. Finally, a later missive to Maxey hinted that Gano was frustrated with General Cooper, whom Gano thought "very cautious, and I am satisfied some good opportunities have and are being presented." Richard Gano to Samuel Bell Maxey, August 29, 1864. Maxey Papers, HCAR, GI.

${ }^{451}$ Richard Gano to Samuel Bell Maxey, August 29, 1864. Maxey Papers, HCAR, GI. 
already approved a major expedition north from Arkansas into Missouri under General Sterling Price. When General Maxey forwarded his commanders' desire to take the offensive, General Smith acquiesced and ordered "the two expeditions should march so as to be in the field of operations about the same time." Generals Gano and Watie would cooperate and strike before October $1 .{ }^{452}$

Eager for mischief, Generals Gano and Watie met in mid-September to hash out the details of their grand raid. Their plans were shaped by the arrival of fresh intelligence from Douglas Cooper, who had learned of an isolated Federal detachment cutting hay near the Grand River in Cherokee Nation. It was further expected that a Federal supply wagon from Fort Scott should be passing through the area any day. Watie was thoroughly familiar with the area, having clashed and been defeated by Federal forces at Cabin Creek off the Grand River the prior summer. The two men would sweep north, attack the hay camp, strike any nearby supply trains, threaten Fort Gibson if the opportunity presented, then ride back south. Of the same rank, the two men simply agreed to act "together and harmoniously" rather than designate an overall commander. Gano's brigade numbered 1,200 Texans with six guns, and Watie's forces consisted of 800 Cherokee, Creek, and Seminole Indians. ${ }^{453}$

The Rebel raiders crossed the Arkansas River on September 15, and the following day they crossed the Verdigris River and approached the Federal detachment gathering hay. The Federals were stationed along the Texas Road on Flat Rock Creek, not far from the Grand River

${ }^{452}$ W.R. Boggs to Samuel Bell Maxey, August 26, 1864, Official Records 41:2, 1082.

453 "Reports of Brig. Gen. Douglas H. Cooper," September 14, 1864, Official Records 41:1, 781; "Reports of Brig. Gen. Stand Watie," October 3, 1864, Official Records 41:1, 784-788; "Reports of Brig. Gen. Richard M. Gano," September 29, 1864, Official Records 41:1, 788-791. Gano's brigade consisted of the $29^{\text {th }}$ Texas Cavalry (Lt. Col. Welch), $30^{\text {th }}$ Texas Cavalry (Col. Gurley), $31^{\text {st }}$ Texas Cavalry (Hardeman's), $5^{\text {th }}$ Texas Partisan Rangers (Col. Martin), and Sylvanus Howell's six gun battery. Watie's brigade consisted of the $1^{\text {st }}$ Cherokee Regiment (Lt. Col. Vann), $2^{\text {nd }}$ Cherokee Regiment (Maj. Vann), $1^{\text {st }}$ Creek Regiment (Lt. Col. Checote), $2^{\text {nd }}$ Creek Regiment (Col. Barnett), and Seminoles under John Jumper. 
and over a dozen miles north of Fort Gibson. The pair of Confederate generals quickly agreed upon a plan, sending First Cherokee and Thirtieth Texas Cavalry on a flanking maneuver towards the south around the enemy's right flank. While the Texans and Cherokees maneuvered around the unsuspecting foe, Gano and Watie watched from a nearby hilltop, and with "spy glasses could see them at working making hay, little dreaming that the rebels were watching them." Having surveilled the area while the flanking column moved along, the generals deployed their forces for the main attack: Watie's Indians on the left, Gano's Texans in the center and right. The Rebel forces swept forward, with the flanking detachment firmly in behind the enemy. "The clouds looked somber," Gano reported, "and the V-shape procession grand as we moved forward in the work of death." ${ }^{254}$

The unsuspecting Federal detachment guarding the hay party consisted of 125 men belonging to the veteran $1^{\text {st }}$ Kansas Colored Infantry and the $2^{\text {nd }}$ Kansas Cavalry. Union pickets offered an early warning of the enemy's advance, estimating the Rebel force at 200, and the small escort party formed in a ravine "to repel an attack or protect the hay." Yet it quickly became clear the Rebels were far larger than believed. The Rebels attacked the small Federal force "from five different points." Dismounted Confederates advanced while the cavalry made several charges, "handsomely repulsed by the colored infantry and dismounted cavalry." General Gano sent an officer forward to demand the Federals' surrender, but "they fired upon my flag and then commenced the work of death in earnest." The Federals continued to fight, but pushed back into Flat Rock Creek and surrounded by the enemy, their situation was hopeless. Desperate, the Kansan troopers made a mounted charge attempting to break out, but only fifteen managed to

\footnotetext{
454 "Reports of Brig. Gen. Stand Watie," October 3, 1864, Official Records 41:1, 784-788; "Reports of Brig. Gen. Richard M. Gano," September 29, 1864, Official Records 41:1, 788-791; The Standard [Clarksville, TX], October 15, 1864.
} 
escape. Left to fend for themselves, black soldiers of the $1^{\text {st }}$ Kansas Colored fell back along Flat Rock Creek and continued to resist until ammunition ran out. Compounding their disaster, Texan artillery was brought up. "One shot was thrown in their midst, and had the desired effect" one Rebel reported, "they scattered in all directions along the Creek." ${ }^{455}$

As was becoming standard in racial clashes in the region, Confederate soldiers showed the African-American soldiers no mercy and killed many blacks after the battle. The only survivors were the few Kansans who broke out and a few black soldiers who "concealed themselves in a ravine untill [sic] dark and then crawled away." General Gano crowed, "The sun witnessed our complete success, and its last lingering rays rested upon a field of blood. Seventythree Federals, mostly negroes, lay dead upon the field." Gano remained silent on how those black soldiers died. Private Jefferson Baze of the $30^{\text {th }}$ Texas Cavalry was less obtuse. He remembered "the negroes were nearly all killed in a little creek...The water was red with the blood of the dead negroes." Writing back to the Clarksville Standard in Texas, an unnamed correspondent reported that some black soldiers attempted to hide in the creek with their noses just above the water. The "native sagacity" of the Indians flushed out the black soldiers. "Call to memory the Choctaws at Poison Springs," the Texan admitted, "and you have the remainder of the fight described." After the butchery was over, Watie's Indians pulled the black bodies from the ravine and stripped them. ${ }^{456}$

455 "Report of Capt. Edgar A. Barker," September 20, 1864, Official Records 41:1, 771-772; "Reports of Brig. Gen. Stand Watie," October 3, 1864, Official Records 41:1, 784-788; "Reports of Brig. Gen. Richard M. Gano," September 29, 1864, Official Records 41:1, 788-791; The Standard [Clarksville, TX], October 15, 1864. ${ }^{456}$ John R. Graton to Adelaide Graton, September 29, 1864, John R. Graton Papers, Kansas Historical Society, Topeka, KS (hereinafter referred to as KHS); "Reports of Brig. Gen. Richard M. Gano," September 29, 1864, Official Records 41:1, 788-791; Yeary, ed., Reminiscences of the Boys in Gray, 45-46; The Standard [Clarksville, TX], October 15, 1864. Stationed at nearby Fort Gibson, Henry Strong of the $12^{\text {th }}$ Kansas Infantry recorded the following day in his diary, "The report today is that they [both black and white Kansans] are nearly all killed and taken prisoners." As reports filtered into Gibson, the garrison prepared for a possible attack. Strong, " $A$ Rough Introduction to This Sunny Land," 59. 
Having defeated the small Union contingent, Rebel forces plundered the small Federal camp for goods. They set alight several thousand tons of hay, likewise destroying the mowing machines, wagons, and other equipment. Yet the Rebels did not linger. They learned from captured Kansans that the wagon train from Fort Scott was headed down the Texas Road and was indeed in the vicinity. Over the next few days, Confederate forces spread out along the Texas Road and clashed with several small parties of Federals, keeping a watchful eye for the coveted supply train. ${ }^{457}$

While the Rebels kept lookout, the Federal wagon train received warning from Fort Gibson that Confederate raiders were prowling the area. With 300 wagons and a considerable mule herd to protect, Major Henry Hopkins — commander of the train's escort—was ordered to hurry ahead to Cabin Creek, a strong defensive position which included a small stockade. From there, Hopkins and his men would await further orders. Included among Hopkins' 610 man escort were elements of the $2^{\text {nd }}, 6^{\text {th }}$, and $14^{\text {th }}$ Cavalry, along with 310 Cherokees of the $1^{\text {st }}$ and $2^{\text {nd }}$ Indian Home Guard. The wagon train and escort reached the apparent safety of Cabin Creek on the morning of September 18. Furthermore, the Federals knew that a relief column consisting of six companies of the $3^{\text {rd }}$ Indian Home Guard was en route. Unbeknownst to Hopkins, another relief force of 2,500 men, including the remainder of the $1^{\text {st }}$ Kansas Colored Infantry, was on the way from the vicinity of Fort Smith under Col. James Williams. ${ }^{458}$

Within a few hours, Confederates discovered the Federals' whereabouts. General Gano personally led a 400-man scouting party north along the Texas Road, and in the afternoon, the

\footnotetext{
${ }^{457}$ Report of Capt. Edgar A. Barker," September 20, 1864, Official Records 41:1, 771-772; "Reports of Brig. Gen. Stand Watie," October 3, 1864, Official Records 41:1, 784-788; "Reports of Brig. Gen. Richard M. Gano," September 29, 1864, Official Records 41:1, 788-791; The Standard [Clarksville, TX], October 15, 1864. 458 "Reports of Maj. Henry Hopkins," September 22 and 25, 1864, Official Records 41:1, 766-771; Lull, James M. Williams, 138; John R. Graton to Adelaide Graton, September 29, 1864, Graton Papers, KHS.
} 
Kentuckian discovered the Federal train encamped at Cabin Creek. Undetected for the moment, Gano fired off a message to Stand Watie to bring up the rest of the Confederate force. While Gano's Texans awaited reinforcements, the Federals roused to the Rebels' presence but did not determine their strength. Finally, around midnight, Watie arrived. The Kentuckian and Cherokee generals "agreed to move on the enemy at once, who was aware of our approach, but entirely ignorant of our numbers." Facing north, Watie's Indians formed on the left while Gano's Texans occupied the right. The Rebels occupied "an elevated prairie that descended to the enemy's position on the creek." With the bright moon to shining behind them, the 2,000 Rebels advanced. ${ }^{459}$

Major Henry Hopkins' Federal escort occupied a strong position. The Federals were formed in line of battle north of Cabin Creek, awaiting the Rebels approach amidst the cover of the timber and brush lining the creek. On the left side of their line, the Federals enjoyed the benefit of Joseph L. Martin's small home, which had been transformed into an impromptu fortification by the addition of a wooden stockade. In front of the small post, the Federals had aligned ten large ricks of hay parallel to the creek, offering additional cover. Behind the post, the Federal wagon train was partially circled, and the train's teamsters were armed. In front of the Federal line, picket posts offered early warning, and around midnight the Federal pickets sounded the alarm. ${ }^{460}$

Unsure of what to expect, Major Hopkins ordered Captain Patrick Cosgrove of the $2^{\text {nd }}$ Kansas Cavalry to reinforce the forward picket post with two dozen men. Riding forward in the

459 "Reports of Brig. Gen. Richard M. Gano," September 29, 1864, Official Records 41:1, 788-791; "Reports of Brig. Gen. Stand Watie," October 3, 1864, Official Records 41:1, 784-788; "Reports of Maj. Henry Hopkins," September 22 and September 25, 1864, Official Records 41:1, 766-771.

460 "Reports of Maj. Henry Hopkins," September 22 and September 25, 1864, Official Records 41:1, 766771; “Reports of Brig. Gen. Stand Watie," October 3, 1864, Official Records 41:1, 784-788. 
moonlit darkness, Cosgrove nearly blundered into the Confederate lines. Pulling back, he sent word of the Rebel advance and took command of the pickets' skirmishing with the advancing foe. As the Confederates drew nearer, the two sides came within speaking distance of one another, and a somewhat absurd conversation between Captain Cosgrove and General Gano broke out. Perhaps hoping to secure a surrender, Gano called out for the enemy to identify themselves. Cosgrove simply replied, "Federals." Returning the question, Gano responded "Rebels, by God." Cosgrove then "called on God to damn us," as Gano later noted, "and invited us to come forward." Gano asked for a flag of truce, and Captain Cosgrove dutifully sent word back to Major Hopkins of the offer. Hopkins was willing to meet with the Rebels and ordered Cosgrove to accept the flag. ${ }^{461}$

Yet this back and forth took time, and Gano interpreted the delay as a bit of Yankee trickery. Growing suspicious the Federals were attempting to withdraw the wagon train, Gano advanced his men another two hundred yards. The Federals in turn saw the Rebels' advance as an abuse of the irregular truce. With both sides impatient and misunderstanding the situation, the truce broke down. Commanding only a small picket post, Cosgrove refused to allow the Confederates to advance further and opened fire. The Rebels charged and pushed Cosgrove back, and around 3 a.m. fighting erupted along the entire length of the Union and Confederate lines. Major Hopkins still didn’t fully understand his predicament; he still believed he was facing 600800 Confederate raiders bereft of artillery. Holding off such a force seemed manageable, especially with reinforcements from the $3^{\text {rd }}$ Indian on the way. Hopkins was willing to fight it out

461 "Reports of Maj. Henry Hopkins," September 22 and September 25, 1864, Official Records 41:1, 766771; "Report of Col. Charles R. Jennison," September 22, 1864, Official Records 41:1, 772-774; "Reports of Brig. Gen. Richard M. Gano," September 29, 1864, Official Records 41:1, 788-791. 
and "encouraged my men to hold out until daylight," when the Kansan captain hoped reinforcements would arrive. ${ }^{462}$

Engaged in a rare night battle, the fighting was confused. Though the "firing was heavy and incessant," Stand Watie confessed "it was difficult to ascertain the enemy's exact position and strength." Yet Major Hopkins was becoming aware the Confederate foe to his front was far greater than expected. When the Confederates opened up with artillery, it proved an ugly surprise. In a reverse of the First Battle of Cabin Creek a year prior, the Confederates now enjoyed the advantage in artillery and opened up a devastating "cross-fire" on the Federals' position. As the Confederates advanced in two lines and artillery rounds landed nearby, Union teamsters panicked and "stampeded," cutting mules free from the wagons and riding north towards Fort Scott. The teamsters' rout not only left the Federal forces shorthanded, but it also stranded the wagon train. The train's immobility proved critical. During the night, Watie's Indians managed to overrun part of the Federal wagon train on the far right of the Union line and withdraw them to the Rebel rear. ${ }^{463}$

With part of the train in Confederate hands and the rest of the train immobile, Gano ordered his forces "back under the brow of the hill" to rest for an hour until daybreak. As the sun rose, the Confederate raiders gained full view of the enemy position for the first time. Still fearful the trains might escape, Watie ordered his Cherokee regiments on the left to cross the creek with support of Texan artillery. Though unnecessary (the trains were stuck), this lodgment on the north side of the creek offered an "advantageous position" for a renewed Confederate

462 "Reports of Brig. Gen. Richard M. Gano," September 29, 1864, Official Records 41:1, 788-791; "Reports of Maj. Henry Hopkins," September 22 and September 25, 1864, Official Records 41:1, 766-771; "Report of Col. Charles R. Jennison," September 22, 1864, Official Records 41:1, 772-774.

463 “Reports of Brig. Gen. Stand Watie," October 3, 1864, Official Records 41:1, 784-788; "Reports of Maj. Henry Hopkins," September 22 and September 25, 1864, Official Records 41:1, 766-771. 
assault. Confederate artillery opened from 100 yards, focusing fire on the hay ricks, wagon train, and stockade. ${ }^{464}$

While Watie's Cherokees and the Texan guns wreaked havoc among the Federals, Gano sent John Jumper's Seminoles and the $30^{\text {th }}$ Texas Cavalry on a wide flanking maneuver to the left. The Confederates' attack bent back the Federal right flank, with Gano personally leading a charge of the $30^{\text {th }}$ Texas, but the blue-clad troopers rallied and made a stand. The battle boiled to a violent crescendo. "Crash after crash swept Yankees, negroes, Pins, and mules away from the land of the living," enthused Gano, "and the brave Indians, having replenished their ammunition, came again to the work, and all with a loud shout rushed on to victory, driving the enemy beyond their fortifications, from where they fled in wild confusion." As the flank gave way and the escort fled, Major Hopkins desperately tried to gather the "scattered troops" of his command and reform them near the Grand River, several miles to the east. The wagon train was lost, and the Confederate avenged their loss on the same ground a year prior. The Federals reported no more than 35 casualties at the Second Battle of Cabin Creek, but their Confederate foes claimed 97 killed and 111 taken prisoners. Confederate reports claimed 7 killed and 38 wounded among their own ranks. 465

With the Federals routed, the Confederate raiders took stock of their newly captured, long sought-after wagon train. Approximately \$1,500,000 worth of goods now lay in Rebel hands, including sutler's goods and governments stores. The Confederate generals were able to clothe their entire 2,000 man command from the train's stores. Reports reached Union lines that

464 “Reports of Brig. Gen. Richard M. Gano," September 29, 1864, Official Records 41:1, 788-791; "Reports of Brig. Gen. Stand Watie," October 3, 1864, Official Records 41:1, 784-788; "Reports of Maj. Henry Hopkins," September 22 and September 25, 1864, Official Records 41:1, 766-771.

465 "Reports of Brig. Gen. Richard M. Gano," September 29, 1864, Official Records 41:1, 788-791; "Reports of Brig. Gen. Stand Watie," October 3, 1864, Official Records 41:1, 784-788; "Reports of Maj. Henry Hopkins," September 22 and September 25, 1864, Official Records 41:1, 766-771; T.B. Heiston, "General Orders No. 26," September 30, 1864, Official Records 41:1, 792-793. 
Confederate Cherokees got drunk on liquor found in the trains and killed wounded. While the Rebel raiders pilfered the train, Generals Gano and Watie worked to get the train mobile. Over 100 wagons were simply too broke down to travel and were set alight. So too were thousands of pounds of hay burned, and the dense smoke was visible to the routed Federals miles away. The remaining 130 wagon, along with 740 mules, were hitched up and prepared to move. The Confederates were anxious to get the immense train moving south, in hopes of quickly reaching the relatively safe territory south of the Arkansas River. ${ }^{466}$

The Confederates' escape from Cabin Creek did not come easily. Although reinforcements had not arrived in time to save Major Hopkins or the train, they were not far off, either. As the Confederates worked their way south on September 19, they found the brigade of Colonel James M. Williams, including the bulk of the $1^{\text {st }}$ Kansas Colored Infantry, blocking their path at Pryor's Creek. Word had reached William's Federals of the disaster at Cabin Creek, and they were hopeful they could block the Rebels' escape. Yet the Federals were in poor condition for a fight. They had marched eighty-two miles in forty-six hours and were "exhausted from hard marching without rest." Still, the game if tired Federals nevertheless formed into line of battle, and Col. Williams deployed his Parrott rifles to good effect. The Federals' rifled artillery enjoyed longer ranger and greater accuracy than the Confederates' guns. Captain John Graton of the $1^{\text {st }}$ Kansas Colored happily recounted to his wife that "the second shot from our guns struck right in front of theirs you had better believe there was some scampering to get away from there."

466 "Reports of Brig. Gen. Richard M. Gano," September 29, 1864, Official Records 41:1, 788-791; "Reports of Brig. Gen. Stand Watie," October 3, 1864, Official Records 41:1, 784-788; "Report of Col. Charles R. Jennison," September 22, 1864, Official Records 41:1, 772-774. 
Throughout the day, scattered skirmishing sputtered along and artillery dueled. Captain Graton got the impression the enemy "did not seem very anxious to attack."

John Graton's comment proved prescient. Although Watie and Gano both claimed they pushed Williams' force back several miles (Williams' report claimed the opposite), Confederates had no real interest in a fight. Their focus was escaping with their captured wagon train. To that effect, Richard Gano engaged in some trickery of his own. Ordering a single empty wagon to be run over a patch of stony ground throughout the night, Gano hoped to give the impression the wagon train was being parked in the Rebel rear. In reality, the train was sent "with all possible dispatch toward the Arkansas River." The next morning, the Federals discovered to their chagrin the enemy "had got the train beyond our reach." Since the Rebels were primarily cavalry, they were simply able to ride away from the battlefield once the train made goods its escape, leaving Colonel Williams and his foot soldiers frustrated. ${ }^{468}$

Hurrying south "with all dispatch day and night" over the next few days, the Confederates made good their escape. The Rebel raiders returned to a hero's welcome. General Douglas Cooper issued congratulatory orders, declaring "The brilliancy and completeness of this expedition has not been excelled in the history of the war." Generals Gano and Watie were complimentary to each other and their respective commands; Watie praised "the greatest unanimity and good feeling existed between the officers and men of the two brigades." General Samuel Bell Maxey heralded the raid as part of a wider series of Confederate successes that

467 “Report of Col. James M. Williams," September 20, 1864, Official Records 41:1, 765; "Reports of Brig. Gen. Richard M. Gano," September 29, 1864, Official Records 41:1, 788-791; "Reports of Brig. Gen. Stand Watie," October 3, 1864, Official Records 41:1, 784-788; John R. Graton to Adelaide Graton, September 29, 1864, Graton Papers, KHS; Strong, “A Rough Introduction to This Sunny Land,” 60.

468 "Report of Col. James M. Williams," September 20, 1864, Official Records 41:1, 765; "Reports of Brig. Gen. Richard M. Gano," September 29, 1864, Official Records 41:1, 788-791; "Reports of Brig. Gen. Stand Watie," October 3, 1864, Official Records 41:1, 784-788; John R. Graton to Adelaide Graton, September 29, 1864, Graton Papers, KHS. 
summer: repelling the Federal invaders in Arkansas, the capture of the J.R. Williams, the victory at Massard Prairie and operations around Fort Smith, the and now the victories at Flat Rock and Cabin Creeks. Confederate morale soared in the wake of these victories, no doubt in part due to the material spoils that accompanied them. Yet Maxey also conceded "there is a cruel enemy still cursing your country; there is still work to do." ${ }^{469}$

General Maxey's words highlight the hollowness of Confederate operations in Indian Territory and Arkansas in 1864 . The 1864 campaign season was a veritable flurry of activity; arguably the most military active season in Indian Territory during the entire war. Confederates enjoyed an unprecedented string of successes, and Federal commanders were frustrated. The United States' attempt to liberate southern Arkansas and north Louisiana had been disastrously foiled, and defeats at Massard Prairie and Cabin Creek were embarrassing and spoke of mismanagement.

Yet Confederate victories failed to alter the larger strategic picture in any way. The Federals still firmly controlled Fort Gibson, Fort Smith, Little Rock, and the Arkansas River line. Though the defeat at Cabin Creek ensured the garrison at Fort Gibson would go hungry for a while, the Confederates hasty escape southward attested to the United States' firm control over the territory north of the Arkansas. In 1863, Fort Gibson was a lone Federal outpost on the Arkansas River, far in advance of the Union line of operations. The capture of a wagon train the year prior would've meant starvation, surrender, or evacuation. By 1864, however, the loss of their wagon train was an embarrassment, a discomfort, and nothing more. For all their tidy victories and brilliant raids, Confederate forces in Indian Territory were still trapped south of the

469 "Reports of Brig. Gen. Richard M. Gano," September 29, 1864, Official Records 41:1, 788-791; T.B. Heiston, "General Orders No. 26," September 30, 1864, Official Records 41:1, 792-793; "Reports of Brig. Gen. Stand Watie," October 3, 1864, Official Records 41:1, 784-788; Samuel Bell Maxey, "General Orders No. 61," October 7, 1864, Official Records 41:1, 793-794. 
Arkansas River; for Confederate Indians, their homelands were still occupied by the enemy. That situation wouldn't change in the coming months. ${ }^{470}$

The 1864 campaigns also witnessed a crescendo in racial atrocity and scalping in Indian Territory. The most infamous example were Choctaw and Texan atrocities at Poison Spring, usually (and rightly) attributed to racial motivations. Yet in the case of the Choctaw, these atrocities also stemmed from a desire for revenge for the plunder of their homelands just weeks earlier by Federal forces under Colonel William Phillips, whose Kansan troopers reportedly mutilated Indian bodies. As the campaign season wore on, the massacre of African-American soldiers continued at Flat Rock Creek and Cabin Creek. In short, by the end of the Civil War, racial massacres and mutilation were fundamental aspects of wartime Indian Territory.

The 1864 campaigns also proved to be the last. As if compensating for the tide of battles, raids, and skirmishes in 1864, both Confederate and Union forces settled down for the autumn and winter seasons. The Second Battle of Cabin Creek proved to be the last major engagement of the Civil War in Indian Territory. While militarily quiet, the always roiling military politics of Indian Territory continued unabated in the last winter of the war. Douglas Cooper, continually aggrieved that he did not hold district command, continued a quiet campaign to oust Samuel Bell Maxey — by all account an efficient and well-liked commander-from his post. Cooper's complaints eventually reached his old friend Jefferson Davis and Richmond. General Maxey, sensing the ground shifting underneath his feet, resigned. Douglas Cooper was appointed commander of the District of Indian Territory in the spring of 1865. A mediocre officer

\footnotetext{
${ }^{470}$ Lary and Donald Rampp argue that Confederate fortunes in the region continually declined after the fall of Fort Smith in the autumn of 1863. Lary C. Rampp and Donald L. Rampp, The Civil War in Indian Territory (Austin, TX: Presidial Press, 1975), 123-125.
} 
inheriting a weary, exhausted district, Cooper ironically could do little militarily when he finally ascended to the command he always wanted.

Federal forces likewise underwent command changes. General J.J. Reynolds assumed command of the District, and General Cyrus Bussey took command of the critical border post of Fort Smith. Yet as the Union army focused on strangling Richmond and cutting the Confederacy in two in the Western Theater, Federal forces in the Trans-Mississippi were largely content to cling to the Arkansas River line. After years of intra-tribal warfare, Federal invasions, ceaseless raiding, innumerable skirmishes, the war in Indian Territory quietly began to fade away.

It was in this chaotic summer of expeditions and raids and massacres that the Loyal Indian refugees finally returned home. Having spent years struggling to survive in camps in central Kansas, they accompanied the Union army wagon trains to Fort Gibson in June of 1864. It was not the jubilant homecoming they might've hoped for. "We can see nothing but Starvation before us, already we have had a taste of what is to come this winter," Creek leaders pleaded to Indian Commissioner William Dole within a month of arriving at Fort Gibson. "It was a terrible mistake that we were not brought down here in time to raise a crop for ourselves, had that been done, we could in great measure have supported ourselves." The Loyal Indians had simply traded refugee camps in Kansas for new ones near the Arkansas River. ${ }^{471}$

This was not the first time Native American refugees from Indian Territory attempted to return home. Hundreds, perhaps even over a thousand, of Creeks and Seminoles had accompanied the First Indian Expedition into the Territory in the summer of 1862. With many Native American men serving in the Indian Home Guard, it's probable many of these refugees

${ }^{471}$ Oktaharsharjo, et. al. to William P. Dole, July 16, 1864, Creek Agency, Letters Received, OIA, RBIA National Archives, Washington, D.C. 
were family members. When the expeditionary forces mutinied and retreated north to Kansas, many of the refugees felt "entirely unprotected" and worried the Rebels would "cause a reign of terror among the loyal Indian families who had returned to their homes."472

In the summer of 1863, as Federal forces returned to Indian Territory again to occupy Fort Gibson, Colonel William Phillips requested that the Cherokees in Kansas be allowed to return home. The Cherokees and their Indian Agent Justin Harlan were assured by Colonel Phillips they would be protected upon their return. Roughly 1,000 Cherokee Indians returned to Cherokee Nation, and Agent Harlan provided vital seed and farming supplies necessary to raising a crop. Yet Union military authorities proved overzealous in their capabilities. Col. Phillips and his forces were clinging to their defenses at Fort Gibson, fighting to keep the supply lines open. Unable to protect the Loyal Cherokees in the countryside, in May Rebel raiders under Stand Watie prowled the countryside and "robbed the women and children of everything they could find," stripping the refugees of food, horses, livestock, wagons, seeds and farming tools, clothing, and bedding. Reports of murder and burned homes circulated as well. As Agent Harlon mourned, "Their destitution is almost complete." Bereft of security, property, or food, the Cherokees moved towards Fort Gibson for protection. The cause of the Cherokees' woes, the Union army now had to feed and clothe the Cherokee refugees at Fort Gibson throughout the winter of $1863-1864 .^{473}$

By the spring of 1864, despite these earlier migrations of refugees to Indian Territory, thousands of Native American refugees still resided in Kansas. Yet the victory at Honey Springs and permanent occupations of Fort Gibson and Fort Smith afforded an opportunity for larger

${ }^{472}$ Britton, Union Indian Brigade, 62, 73-74; Dale, "The Cherokees in the Confederacy," 159-185.

${ }^{473}$ Report of William G. Coffin, September 24, 1863, Annual Report of the Commissioner of Indian Affairs [1863] (Washington, D.C.: G.P.O., 1863), 173-178; Report of Justin Harlan, September 2, 1863, Annual Report of the Commissioner of Indian Affairs [1863], 179-181. 
numbers of refugees to return home. As ever, the Loyal Indians desired to return home. Due to winter conditions, scarce grass, and high water conditions, however, the Indians did not depart for Indian Territory until mid-May. Southern Superintendent of Indian Affairs William Coffin oversaw the removal of 5,000 Native Americans from Kansas down into Indian Territory, a relatively smooth journey took nearly a month. On June 15, the Loyal Indians arrived in the vicinity of Fort Gibson. ${ }^{474}$

While the delayed departure date from Kansas afforded easier travel, it also ensured the Native refugees arrived too late to plant crops. Creek Chief Oktaharsharjo learned that Indians who had already migrated to Indian Territory nearly starved in the winter of 1863-1864, resorting to "hunt out the little corn that fell from the $\underline{\text { Horses }}$ and $\underline{\text { Mules }}$ of the military." With thousands more refugee mouths to feed as the winter of 1864-1865 approached, Oktaharsharjo worried "the suffering must be much greater next winter, than it was last, unless the most prompt and energetic steps are taken to procure and transport supplies to this place." Military authorities struggled to keep the Indians fed, each arrival of a wagon train bringing just enough to stave off starvation. ${ }^{475}$

For the Loyal Creeks in particular, their return to Indian Territory proved difficult. While Cherokees could return to their homes north of the Arkansas River, much of the Creek Nation lay in the no-man's-land south of the Arkansas. In January, Oktaharsharjo reported that his people were encamped in low-lying swampland across the river "within two or three of our own country and wishing anxiously to be in our own dear country; but without any prospect of

\footnotetext{
${ }^{474}$ Report of William G. Coffin, September 24, 1864, Annual Report of the Commissioner of Indian Affairs [1864] (Washington, D.C.: G.P.O., 1864), 303-304.

${ }^{475}$ Oktaharsharjo, et. al. to William P. Dole, July 16, 1864, Creek Agency, Letters Received, OIA, RBIA, National Archives; Oktaharsharjo et. al. to William P. Dole, January 11, 1865, Creek Agency, Letters Received, OIA, RBIA, National Archives; Report of William G. Coffin, September 24, 1864, Annual Report of the Commissioner of Indian Affairs [1864], 303-304.
} 
moving into it." Oktaharsharjo pleaded with U.S. authorities to offer protection, citing "the Treaties made by them to our forefathers," which "guarantee to us protections and in accordance with these treaties we hope \& beg for protection." The Creeks also emphasized their desire to "raise our own provisions for next year," which necessitated returning home. ${ }^{476}$

Unfortunately for the Creeks and many other refugees, returning home simply wasn't a viable option. Focused on decisively defeating the Confederacy elsewhere, relatively few troops were assigned to Indian Territory. Without the protection of Federal troops, it was unsafe for many to return home, which in turn meant the Loyal Indians remained refugees—entirely dependent on the United States for survival.

The return of the Loyal Indians in 1864 contributed dramatically to an already burgeoning refugee crises in Indian Territory. After two Federal invasions in 1862 and 1863, the Phillips's Expedition into Choctaw and Chickasaw Nations in 1864, and innumerable raids, skirmishes, and guerrilla actions, most of Indian Territory's civilian denizens were destitute. As we have seen, the war in Indian Territory often proved brutal, with scalpings and atrocities occurring with some frequency. Yet this military brutality mirrored the blurring of military and civilian lines throughout the war years. As control of Indian Territory continually changed hands, often leaving no one in charge at all, it was easy for soldiers to engaged in theft and murder. Guerrillas turned bandit. Civilians settled old scores. And the ranks of the refugees continually swelled.

Civilians often suffered at the hands of Indians whose loyalties differed from their own. Cherokee minister Stephen Foreman, a self-professed "Watie man," complained of the violence

${ }^{476}$ Oktaharsharjo et. al. to William P. Dole, December 9, 1864, Creek Agency, Letters Received, OIA, RBIA, National Archives; Oktaharsharjo et. al. to William P. Dole, January 11, 1865, Creek Agency, Letters Received, OIA, RBIA, National Archives. 
that pro-Union "Pin" Indians waged against their own people in the summer of 1862. His diary recorded the litany of rumors and misdeeds that spoke of fear sweeping the countryside. "Mr. Ursery, a white man with a Cherokee family - they [Pins] cut him up alive." He heard rumors o the murder of his brother Alex Foreman, and also of Abijah Hicks, "an inoffensive man and if killed, it was either for his abolition sentiments or his property, for no one with a good horse or any property is safe." As several points Reverend Foreman feared for his own life, sleeping in his cornfield at the behest of his children who "urged me to leave and save my life if I could."477

The rumor of Abjiah Hicks proved true. Despite Abijah's pro-Northern and abolitionist persuasion, he was reportedly killed 'by the 'Pins,' but through mistake intending to kill another man," his widowed wife Hannah Hicks mourned. "If it was a mistake 'twas a terrible one for me," she grieved to her diary. Despite her Northern sentiments, Hannah helped hide her neighbor Reverend Foreman from Pin Indians. She helped him despite rumors that he had encouraged the death of her husband for his Northern sentiments. The relationship between Hannah and Stephen speaks to the divided loyalties and confused politics that resided among Indian neighbors during the war. ${ }^{478}$

Hannah Hicks's collective wartime experiences speak to the devastation visited upon civilians by soldiers. Her brother Dwight was jailed with "no charge against him, only that he has confessed that his preference of opinion is for the North." Although her brother was eventually paroled, the twenty-eight year old Hannah was left to raise her five children alone. On November

${ }^{477}$ Stephen Foreman Papers, diary entries, July 6, 16-17, 1862, WHC, OU.

${ }^{478}$ Hannah Hicks diary, Samuel Austin Worcester Papers, HCAR, GI. Hannah learned that the "'Pins' about here took it into their heads that [Foreman] had a hand in the murder of my husband, i.e. that he was 'knowing to it,' \& encouraged it and he was known to be a Southerner anyhow, and would have killed them quickly if they could have found him." Hicks came to believe "his influence helped to cause the murder of my husband, and the arrest of [my] brother." Given Foreman's register of surprise in his own diary of Abijah's death, it seems unlikely he knew or played a role in the murder. Moreover, these rumors contradict Hannah's earlier statement that her husband had been killed by mistake. 
8, 1862 she reported a rumor that Stand Watie's men vowed to "rob every woman whose husband had gone to the Federals, and every woman who has Northern principles, which would include us of course." Nine days later the rumor came true, and Confederate Cherokees whom she knew_-"who have often eaten in my house"—ransacked her house and "overhauled every closet, trunk, box, \& drawer they could find." ${ }^{479}$

Elizabeth Watts, a Cherokee child, recalled her family moving to the vicinity of Fort Gibson during the war. Her father enlisted in the Union army and was stationed at Fort Gibson, where Elizabeth and her mother could also draw rations. Despite their proximity to the fort, they were still visited by four Rebel raiders who "stripped us of everything," including cutting the feather bed to "let the feathers fly in the wind." They took the Watts' food, including the green onions in the yard. "Mother took her best dress and sat on it to hide it," Elizabeth recalled. "They made her get up and tore the dress into strings." Elizabeth remembered that towards the end of the war, "There was lots of raiding parties. They would go over the country, burning all the houses, cabins, barns, and cribs, carrying all the beds and chairs away, and killing or driving away the cattle. ${ }^{480}$

While looting and banditry proved commonplace, so too did more brutal acts take place against civilians. James Barnes, a fourteen year old Arkansan boy, watched Choctaw raiders drag a sick man from his bed, "set him up against a tree and shot him to death." Christine Bates, teenager during the war, recalled "Northern men were so mean to the Choctaw women, they would jerk the ear rings from their ears, and lock them in one stuffy room together, keeping them there for days." ${ }^{481}$

\footnotetext{
${ }^{479}$ Hannah Hicks diary, Samuel Austin Worcester Papers, HCAR, GI.

${ }^{480}$ Interview with Elizabeth Watts, IPP, WHC, OU.

${ }^{481}$ Interview with James Robert Barnes, IPP, WHC, OU; Interview with Christine Bates, IPP, WHC, OU.
} 
Unsurprisingly, given years of discriminate and indiscriminate looting and killing, thousands of Native Americans in Indian Territory became refugees, either homeless or entirely dependent upon Union or Confederate officials for survival. The return of the Loyal Indians from Kansas, unable to plant crops or return home, only exacerbated this refugee crisis. In late 1864, Indian Superintendent William Coffin reported 15,000 "destitute Indians, dependent upon the government for their support. While some Cherokees had managed to raise a humble corn crop, Coffin confessed the crops were exposed "to be plundered and stolen by the vast number of guerillas and thieves, who are infesting their country.” Feeding these Indians fell to the U.S. government and army. ${ }^{482}$

The situation was much the same among the Confederate-controlled portions of Indian Territory. Repeated Federal invasions of Indian Territory prompted many Confederate Cherokees, Creeks, and Seminoles to head south and seek shelter in Choctaw and Chickasaw Nations or North Texas. "Refugees from the Cherokee Nation came in bunches and settled near us during the war," recalled Chickasaw Elizabeth Kemp Mead, whose family lived on the Red River. "They were without food," and young Elizabeth watched the refugees cook mulberry leaves and briar root to stave off starvation. Nearly 15,000 Confederate Indian refugees flooded south, entirely dependent upon Confederate authorities or kind neighbors for relief. ${ }^{483}$

The refugee crisis by 1864-1865 reached staggering proportions. Some 29,000 Native American refugees existed between the United States and Confederacy. Given that the Five Tribes' population in 1860 was approximately 48,000 , nearly $60 \%$ of the Territory's population

\footnotetext{
${ }^{482}$ Report of William G. Coffin, September 24, 1864, Annual Report of the Commissioner of Indian Affairs [1864], 303-304. Coffin also noted that over 1,000 Indian refugees, including nearly 500 Seminoles, were still in Kansas. Afflicted with smallpox, the Seminole could not travel.

${ }^{483}$ Interview with Elizabeth Kemp Mead, IPP, WHC, OU. LeRoy H. Fishcer and William L. McMurry, “Confederate Refugees from Indian Territory," Chronicles of Oklahoma 57:4 (1979), 462; S.S. Scott to James A. Seddon, December 1, 1864, Official Records 41:4, 1086-1090.
} 
were refugees. Three out of every five Indians required assistance from the government.

Although we do not know the definitive number of wartime refugees in the South, Indian

Territory surely ranks as one of the most destitute and refugee-ridden regions across the United

States. $^{484}$

Union and Confederate authorities alike struggled to sustain such a huge refugee

population. Refugees in Union controlled regions often moved to Federal posts for security and access to supplies. Others trekked to forts from longer distances to secure food. As the Cherokee Tomahawk newspaper mused of its hometown Fort Gibson in March, 1865, “Although not exactly a 'city of Refuge,' it may be styled a Refugee city — the greater part of its denizens being left to the tender mercies of Agents and providence (principally Providence).” Jennie McCoy Chambers and her family, who "refugeed' in the Cherokee Nation until the close of the War," routinely walked to Federal posts and back "for supplies from the Government, and many times almost starved." The cost of feeding these Indian refugees was estimated as at least $\$ 600,000 .{ }^{485}$ Under the leadership of Samuel Bell Maxey, who believed it "an act of humanity to provide as best I could for these suffering exiled friends and neighbors," the Confederacy established refugee camps throughout Chickasaw and Choctaw Nations. Maxey appointed officers to take charge of various issues, and distributed food from the Confederate commissary. Although this system was not perfect, it kept Confederate refugees alive and placated. ${ }^{486}$

484 Doran, "Population Statistics of Nineteenth-Century Indian Territory," 501.

485 "Fort Gibson," Cherokee Tomahawk [Fort Gibson, Cherokee Nation], March 13, 1865; Interview with Jennie McCoy Chambers, IPP, WHC, OU; Report of William G. Coffin, September 24, 1864, Annual Report of the Commissioner of Indian Affairs [1864], 304-305. Darkly, the same issue of the Tomahawk also praised the creation of a new graveyard outside of town, much needed since, "Graves meet the eye at every turn, and may cause much sickness as the warm season advances.” Jennie McCoy Chambers recalled walking from Tahlequah to Fort Smith for supplies, but given Tahlequah's distance from Fort Smith and close proximity to Fort Gibson, it seems more likely she and her family traveled to that place.

486 Samuel Bell Maxey, "Report of Superintendent of Indian Affairs," August 23, 1864, Maxey Papers, HCAR, GI; S.S. Scott to James A. Seddon, December 1, 1864, Official Records 41:4, 1086-1090; Fischer and McMurry, "Confederate Refugees," 462. 
By 1865, Native Americans in Indian Territory were destitute, dependent upon the government for survival. As the end of war loomed on the horizon, so did the task of forging new treaties with the United States government. Already riven by pro-Confederate factions that weakened the Indians' standing in the eyes of the Federal government, their refugee status and reliance upon the government for survival left them with relatively little leverage with which to negotiate.

In May 1865, dozens of Native Americans made their way west to Cotton Wood Grove, along the Washita River in western Chickasaw Nation. It was a relatively remote spot, but unlikely to be bothered by Federals and closer to the Plains Indians, who had been invited. Among the Confederate Indian delegations headed to Camp Napoleon were the Cherokee, Choctaw, Chickasaw, Creek, and Seminole, along with the Caddo, Osage, and Comanche. Also destined for Camp Napoleon were "our brothers of the plains," including Kiowas, Arapahoes, Chivans, Lipans, Anadarkoes, and yet more bands of Caddos and Comanches. As the delegations arrived and the council grew in size, the place was dubbed Camp Napoleon. ${ }^{487}$

On May 26, 1865, the "united nations of the Indian Territory" at Camp Napoleon signed a compact which hopefully would allow them to weather the coming days. The compact addressed the fears of both the Five Tribes and the Plains Indians. The Indians acknowledged that "the history of the past admonishes the red man that his one great and powerful race is rapidly passing away as snow beneath the summer sun." They mourned that due to "the vicissitudes of time and change and misfortune and evils of disunion, discord, and war among

${ }^{487}$ Camp Napoleon compact, May 26, 1865, Official Records 48:2, 1102-1103; Anna Lewis, "Camp Napoleon," Chronicles of Oklahoma 9:4 (December, 1931), 359-364. It's unclear why the location was named Camp Napoleon; it existed on what is today the town of Verden, Oklahoma. 
themselves are but a wreck of their former greatness." They worried "on account of our weakness being reduced and hemmed into a small and precarious country that we can scarcely call our own and in which we cannot remain in safety and pursue or peaceful avocations." ${ }^{" 48}$

Faced with uncertainty, both as a race and in the more immediate days ahead as the Confederacy collapsed, the tribes committed themselves to "an Indian confederacy or band of brothers, having for its object the peace, the happiness, and the protection of all alike, and the preservation of our race." They swore "peace and friendship" among the tribes present and declared their "great principle” to be, “"An Indian shall not spill an Indian's blood.”489

The Camp Napoleon Council represented a desperate attempt on the part of Confederate and Plains Native Americans to present a unified front in a time of great uncertainty. Although the compact makes no direct reference to the United States, the end of the war was coming. Knowing that they must forge new treaties with the United States, the Camp Napoleon Council urged the tribes to act in concert to protect their collective sovereignty. Ironically, on the exact same day Native Americans met in council to plan for their post-war fate, General Edmund Kirby Smith surrendered all forces in the Department of Trans-Mississippi to the United States. $^{490}$

Even before the news reached Indian Territory, however, General Douglas Cooper grew concerned over the future of the Five Tribes. Knowing the Indians had already laid the foundation for unified action, Cooper called for a "'Grand Council of the Six Allied Nations"” to meet in Choctaw Nation to "take into consideration the present condition of the country and

${ }^{488}$ Camp Napoleon compact, May 26, 1865, Official Records 48:2, 1102-1103; Lewis, "Camp Napoleon," 359-364. Notable among the delegates included: Jack Spears, James Vann, and William P. Adair, Cherokees;

Tuckabatchee Micco, and Moty Kannard, Creeks; Israel and Nathaniel Folsom, Choctaws; Winchester Colbert and Cyrus Harris, Chickasaws; and John Jumper, Seminole.

${ }^{489}$ Camp Napoleon compact, May 26, 1865, Official Records 48:2, 1102-1103.

490 “Terms of a military convention,” May 26, 1865, Official Records 48:2, 600-601. 
determine what course the 'allies' will take." Until the Grand Council could meet, Cooper hoped to avoid "collision with the Federals." 491

On June 15, at Cleata Yamaha in Choctaw Nation, delegates from the Five Tribes gathered to determine a final course of action. Referencing the unity of Camp Napoleon, the delegates resolved to end hostilities with the opposition factions within their own tribes - the Loyal Indians who remained allied to the United States - and invite them "to co-operate with this council in its efforts to contract anew friendly relations with the United States Government." The council called for commissioners to treat with the United States. Finally, they called for "a cessation of hostilities in order that there be time and opportunity to negotiate with the United States Government.” The Confederate Indians were ready to surrender. ${ }^{492}$

Federal military authorities dispatched Lieutenant Colonel Asa C. Matthews to receive the surrender of the Indian nations and their forces. On June 19, Lt. Col. Matthews met with Principal Chief Peter Pitchlynn of the Choctaw Nation, who had advocated so strongly in favor of neutrality at the beginning of the war. It was now Pitchlynn's duty to end the war he never wanted, and he issued a proclamation for "an immediate cessation of hostilities." "493

On June 23, 1865, Lieutenant Colonel Asa Matthews and Brigadier General Stand Watie met near Doaksville, Choctaw Nation. The two had already agreed to a ceasefire the week prior, but the time had come to formally surrender. Gen. Watie commanded the last significant body of Confederate forces yet to surrender, the Indian division. Most had already been furloughed or

${ }^{491}$ Douglas Cooper to James Throckmorton, May 22, 1865, Record Group 109: War Department Collection of Confederate Records, 1825-1927, Records of the Department of Texas \& the Trans-Mississippi, Letters Sent, District of Indian Territory, May 1865, National Archives, Washington, D.C. Douglas Cooper to Tandy Walker, May 23, 1865, RG 109, Trans-Mississippi Record, Letters Sent, District of Indian Territory, May 1865, National Archives.

492 "Resolutions of the grand council," June 15, 1865, Official Records 48:2, 1103-1104.

${ }^{493}$ Peter Pitchlynn, Proclamation, June 18, 1865, Official Records 48:2, 1105; Asa C. Matthews to Winchester Colbert, June 23, 1865, Official Records 48:2, 1105-1106. 
simply headed home. The two men agreed upon and signed formal terms of surrender for the Cherokee Nation and Watie's command. Formerly Confederate Indians were to peaceably return home. The United States promised to protect them from "not only encroachments on the part of the whites, but also from the Indians who have been engaged in the service of the United States." These same terms were extended to the Creeks, Seminoles, and Osages. On July 14, the Chickasaw Nation submitted to Federal authority - the rebellious factions of all Five Tribes had submitted to United States control. ${ }^{494}$

The surrender of the Confederate Five Tribes and the Indian Division of the Confederate army in June-July, 1865 marked the end of the Civil War in Indian Territory, the TransMississippi, and the continental United States. The Confederate-Indians alliances, forged amid the fears and excitement and fraud of 1861, finally ceased to be. After four years of violent intratribal warfare, ceaseless raids and guerrilla activity, multiple Federal invasions, Native participation in the wider Trans-Mississippi theater, and the havoc wreaked upon civilian communities, the war was over.

Though the firing ended and the quiet of peace returned, the destitution, death, and uncertainty of the future lingered. Thousands of starving Indian refugees required provisions. Almost immediately after surrendering, Cherokee authorities pleaded to Federal forces for aid for the "destitute Indians." Stand Watie likewise reached out to friends in Texas for assistance. For many Native Americans, the end of the war did little to assuage the simple struggle for

${ }^{494}$ A.C. Matthews, W.H. Vance, and Stand Watie, "Treaty stipulations," June 23, 1865, Official Records 48:2, 1100-1101; A.C. Matthews and Winchester Colbert, "Treaty stipulations," July 14, 1865, Official Records 48:2, 1097; James C. Veatch to J. Schuyler Crosby, July 20, 1865, Official Records 48:2, 1095-1097. 
survival. As already noted, nearly three of every five Native Americans was dependent on the government for subsistence. ${ }^{495}$

Many Native Americans did not survive. Although we will never know the exact total lost, the estimated wartime deaths are staggering. During the Civil War, an estimated 4,000 Cherokees (one in five), 2,500 Creeks (one in four), 500 Seminoles (one in five), 500 Chickasaws (one in nine), and perhaps 1,500 Choctaws (one in ten) perished during the Civil War. These deaths left tremendous holes in society. By war's end, for example, one third of Cherokee women were widows, and 1,200 Cherokee children (one in four) were orphans. The Civil War ravaged Native American populations in Indian Territory. It's worth recalling that this population disaster came barely two decades in the wake of removal, which drastically reduced Native populations as well. The Civil War represented the second great population catastrophe for the Five Tribes in the nineteenth century. ${ }^{496}$

Yet for all the devastation, bloodshed, and death, profound questions remained unanswered for the Five Tribes. As Lt. Col. Matthews signed the surrender treaties with the Five Tribes, he also stipulated tribal delegates meet at Armstrong Academy, Choctaw Nation on September 1 to "settle all questions between the Indian nations and the Government." The questions were myriad. What would the new treaty terms with the United States be? What penalties would the United States impose on the Five Tribes? What distinctions — if any — would be made between Loyal Indians and Confederate Indians? Could these two factions, which had so bitterly waged war against one another, reconcile? What would the legal future of these tribes

${ }^{495}$ W.P. Adair and James M. Bell to J.C. Veatch, July 19, 1865, Official Records 48:2, 1099-1100; "Relief for the Indians," The Standard [Clarksville, TX], June 17, 1865.

${ }^{496}$ Mary Jane Warde, When the Wolf Came: The Civil War and the Indian Territory (Fayetteville: University of Arkansas Press, 2013), 264; Debo, Road to Disappearance, 177; Carolyn Ross Johnston, Cherokee Women in Crisis: Trail of Tears, Civil War, and Allotment, 1838-1907 (Tuscaloosa: University of Alabama Press, 2003), 104; Doran, "Population Statistics," 496, 507. 
be? Would they retain sovereignty over their nations? The Civil War radically altered Native American tribes and their relationships with each other. It remained to be seen how the war reshaped their relationship with the United States and their national sovereignty. ${ }^{497}$

${ }^{497}$ James C. Veatch to J. Schuyler Crosby, July 20, 1865, Official Records 48:2, 1095-1097. 


\section{"The Ruthless White Man Demanded It": The Postbellum Era}

"It is a source of gratification to know that the government is determined to make a change in the policy heretofore with the Indian tribes, by so far as possible removing all into an Indian Territory, and inducing them to adopt our form of government, which we think is far better for them than their scattered tribal condition." -J.W. Dunn, Creek Indian Agent, $1865^{498}$

United States Commissioner of Indian Affairs Dennis Cooley addressed the onlookers in the hall in front of him. The meeting between the United States and Indian tribes, once slated for the Armstrong Academy, had been moved to Fort Smith. Special arrangements were made to outfit a room large enough to hold delegations from twelve Native tribes, including the Cherokee, Chickasaw, Choctaw, Creek, and Seminole. After several days of preparations and arrivals, Cooley now opened the council on Friday, September 8, 1865. The Native Americans did not like what Commissioner Cooley had to say. ${ }^{499}$

"Portions of several tribes and nations have attempted to throw off their allegiance to the United States... and have been in open war with those who remained loyal and true, and at war with the United States. All such have rightfully forfeited all annuities and interests in the lands in the Indian territory," Cooley declared. "The President is willing to hear his erring children in extenuation of their great crime. He has authorized us to make new treaties with such nations and tribes as are willing to be at peace among themselves and with the United States." 500

The United States carried seven demands to the Native Americans of Indian Territory. First, the Indians must agree to peace with each other and the United States. Second, Natives in

498 J.W. Dunn to Elijah Sells, September 20, 1865, Annual Report of Commissioner of Indian Affairs for the Year 1865, 291.

499 "Report of D.N. Cooley," October 30, 1865, Annual Report of Commissioner of Indian Affairs for the Year 1865, 296-97.

500 "Report of D.N. Cooley," October 30, 1865, Annual Report of Commissioner of Indian Affairs for the Year 1865, 296-97. 
Indian Territory must aid the United States in ensuring peaceful relations with the Plains Indian tribes. Third, slaves must be emancipated and arrangements made for African-Americans "incorporation into the tribes on an equal footing with the original members, or suitably provided for." Fourth, that slavery be outlawed forever. Fifth, tribes in Indian Territory must sale lands to the United States to accommodate the removal of "the friendly tribes in Kansas and elsewhere." Sixth, "that all the nations and tribes in the Indian territory be formed into one consolidated government." Seventh, that whites were still barred from living in Indian Territory, unless given permission by the United States or tribal governments. ${ }^{501}$

Commissioner Cooley's statements made the United States' position clear. The Five Tribes, having rebelled against the United States, must now pay the price through new treaties. The United States' treaty stipulations promised radical change: slavery was abolished, AfricanAmericans would be incorporated as tribal members (or "suitably provided for"), yet more Native lands would be taken, and most importantly, the United States desired the Five Tribes form a single Native government, extinguishing tribal distinctions. More broadly, the United States hoped to form Indian Territory into a true territory with a single government and likewise impose allotment, whereby lands were no longer held by tribes themselves but instead by individuals (thus opening up large amounts of land for further settlement). These moves would, from the United States' perspective, bring civilization and assimilation to the Indians. The finer points of these treaties were not negotiated at Fort Smith. Instead, Cooley asked the tribes to send delegations of five men each to Washington, D.C. to finalize and sign new treaties with the United States. ${ }^{502}$

501 "Report of D.N. Cooley," October 30, 1865, Annual Report of Commissioner of Indian Affairs for the Year 1865, 297-298.

502 "Report of D.N. Cooley," October 30, 1865, Annual Report of Commissioner of Indian Affairs for the Year 1865, 297-98; Christopher B. Bean, "Who Defines a Nation?: Reconstruction in Indian Territory," in The Civil 
Throughout the following year, the Five Tribes negotiated new treaties in Washington, signing them in 1866 . The Reconstruction treaty terms were not the same for each tribe. Instead, the favorability of the final terms depended on the ability of each tribe to successfully pursue its agenda. This, in turn, hinged on the capability and willingness of each tribe to present a united front towards the United States government. The Choctaws and Chickasaws, who largely escaped the divisiveness of intra-tribal warfare, successfully rallied together and negotiated favorable terms, even going so far as to hire external white lawyers to lobby on their behalf. The Cherokees, Creeks, and Seminoles, torn apart by the Civil War, failed miserably to present a united front. Indeed, the Creeks and Choctaws sent dueling factions (one "Loyal," one "Southern") to Washington and spent much of their energy trying to deny the legitimacy of the opposing party while trumpeting the legality of their own. ${ }^{503}$

The terrible irony of the Reconstruction treaty terms is that they were least favorable to the most loyal tribes (Creek, Seminole, and Cherokee) and most favorable to those tribes who largely remained loyal the Confederacy until the end (Choctaw, Chickasaw). Despite the thousands of Cherokees, Creeks, and Seminoles who fought for the Union, their terms proved the most punitive, primarily due to their inability to unify during negotiations. While the Civil War undermined the sovereignty of all the Five Tribes, it proved the most damaging to those Native Americans who sacrificed the utmost to ensure the United States emerged victorious. ${ }^{504}$

The Cherokees proved unwilling to reconcile their factional divides. As their Indian agent lamented, "The bitterness existing between the loyal and disloyal Cherokees is intense...I fear no

War and Reconstruction in Indian Territory, edited by Bradley R. Clampitt (Lincoln: University of Nebraska Press, 2015), 112.

${ }^{503}$ Bean, "Who Defines a Nation?," 113-117; Clara Sue Kidwell, The Choctaws in Oklahoma: From Tribe to Nation, 1855-1970 (Norman: University of Oklahoma Press, 79-80.

${ }^{504}$ Bean, "Who Defines a Nation?," 113. 
human power can reconcile them." Thus, the Cherokees sent two delegations to Washington, one representing the Loyal Cherokees and the other the Southern Cherokees (as they came to be called). Among the Loyal Cherokee delegation were Chief John Ross, seventy-five years old and bedridden, and John B. Jones, one of the two Baptist missionary founders of the Keetowah Society. The Southern Cherokee delegation included former Confederate Brigadier General Stand Watie. ${ }^{505}$

Presenting a divided front, the United States took advantage, and the resulting treaty cost the Cherokees substantially. Refusing to accede to John Ross' leadership, the Southern Cherokees hoped to negotiate an entirely separate treaty - in essence, formally dividing the Cherokees in two. And while the Federal government did negotiate two separate treaties, it ultimately only accepted the more favorable one. With two competing delegations, the United States played them off each other and made considerable gains. The Cherokees sold their Neutral Lands (a small strip of land to which they laid claim in Kansas) at $\$ 1.25$ per acre to the United States and placed the Cherokee Strip (northwestern Indian Territory) in a Federal trust, and further agreed to allow other tribes to settle on Cherokee lands. Cherokee freedmen (persons formerly enslaved by Cherokees) were given citizenship. ${ }^{506}$

Just like the Cherokee, the Creeks were also divided into Loyal and Southern factions.

The Loyal delegation included Oktaharsharjo, and the Southern delegation included former Confederate Colonel Daniel McIntosh. Perhaps more than any other tribe, the Creeks held bitter divisions from the war. The Loyal Creeks were adamant they be distinguished from their Southern brethren, who had driven them from their homes in 1861. "We now most respectfully

\footnotetext{
505 "Report of Elijah Sells," October 16, 1865, Annual Report of Commissioner of Indian Affairs for the Year 1865, 254; McLoughlin, After the Trail of Tears, 222-227; Woodward, The Cherokees, 301-304.

${ }^{506}$ McLoughlin, After the Trail of Tears, 222-227; Woodward, The Cherokees, 301-304.
} 
ask you if you can show us one single instance in which more suffering has been endured or greater sacrifices made for the cause of the Union," their delegation exclaimed at Fort Smith, "and we most respectfully ask and beg not to be classed with the guilty."

Yet classed with the guilty they were. The Loyal delegation arrived first in Washington and drew up a treaty with the United States before the Southern delegates - who hoped to cooperate — arrived. The Southern delegates weren't recognized by the United States, nor shown the treaty upon their arrival. When they finally discovered the terms, they were shocked. The treaty sold the western half of Creek Nation for a mere thirty cents per acre, the funds of which would compensate Loyal Creeks for wartime losses. The treaty made African Creeks tribal citizens and set aside land for their use. Southern delegates protested, and the United States referred them to the Loyal Creek delegation. While a unified Creek delegation might've negotiated a better deal, the Loyal Creeks simply refused to work with their former Confederate compatriots. They were also desirous to ensure that Creek freedmen were assured citizenship, something the Southern delegation opposed. In short, in a choice between standing firm beside the United States or working with their former enemies, the Loyal Creek delegation chose loyalty to the United States. However noble, it cost the Creek Nation dearly, as they lost half their territorial holdings. ${ }^{508}$

The Seminoles sent a single delegation to Washington, although it contained both Loyal and Southern delegates. The Seminoles, numbering barely 2,000, completely destitute and reliant upon the United States for subsistence, had no leverage whatsoever. The Seminoles sold their entire nation to the United States, over two million acres, at fifteen cents per acre. They were

\footnotetext{
${ }^{507}$ Debo, The Road to Disappearance, 171; Statement of Sanford Berryman, September 12, 1865, Annual Report of Commissioner of Indian Affairs for the Year 1865, 297-298.

${ }^{508}$ Debo, The Road to Disappearance, 171-176; Bean, "Who Defines a Nation?," 114-115.
} 
then sold 200,000 acres of former Creek land (for which the United States paid thirty cents an acre) at fifty cents an acre. The sole Southern Seminole delegate, John F. Brown, protested but to no avail. The Civil War and Treaty of 1866 devastated the tribe. As one scholar noted, "By 1866 , after thirty years in the West, the Seminoles found themselves with little property, no schools, no unified government, a meager subsistence, and in much the same physical state as when they had migrated from Florida." 509

The Choctaws and Chickasaws, free from the factionalism that plagued the other Five Tribes, secured better terms. Their delegation consisted of a number of former Confederate officers, notably Robert M. Jones. To assist them was John H.B. Latrobe, a pro-Union lawyer from Baltimore, who was tasked with securing the antebellum money owed the Choctaws and Chickasaws. Also assisting the Choctaws and Chickasaws was their former Indian agent and Confederate Brigadier General Douglas Hancock Cooper. ${ }^{510}$

Their political unity and white allies paid off. Unlike the other tribes, the Choctaws and Chickasaw gained concessions. They managed to secure promises from the U.S. to honor antebellum treaties, ensuring annuities would continue flowing. While the Choctaws and Chickasaws abolished slavery, they firmly opposed citizenship for freedmen. Pointing to the United States' stipulation at Fort Smith that freedmen need only be "suitably provided for," they instead gave freedmen forty acres while negotiating a clause that tasked the United States with removing the freedmen within two years. The United States never removed the freedmen, however, leaving them "in a kind of legal limbo" for decades. The tribes did sell the Leased District (southwestern Indian Territory) to the United States for $\$ 300,000$, but since almost no

\footnotetext{
${ }^{509}$ George A. Reynolds to Elijah Sells, September 1, 1865, Annual Report of Commissioner of Indian Affairs for the Year 1865, 281-183; Lancaster, Removal Aftershock, 159-165.

${ }^{510}$ Kidwell, The Choctaws of Oklahoma, 78-80.
} 
Choctaws and Chickasaws lived there, this acceptable. All told, the Choctaws and Chickasaws secured incredibly favorable treaty rights from the United States, certainly the most lenient of the Five Tribes. Though they had stood firmly by the Confederacy until the final surrender, their unity at the negotiating table paid dividends. ${ }^{511}$

Aside from individual land sales and the issue of freedmen, all of the Five Tribes made several other critical concessions in the 1866 treaties. The tribes each promised rights of way to at least two railroad lines within their territory (one north-south, one east-west). When the first railroads arrived in 1870, "the inexorable advance of technology and white settlement began." Railroads literally changed the human geography of the region; old tribal towns and meeting places vanished as new towns popped up along railroad routes. Whites used railroads to enter Indian Territory, legally or not. In 1885 , there were 25,000 whites in Indian Territory; by 1890, there were 140,000, outnumbering the Native population. Railroads reshaped Indian Territory and undermined the Five Tribes' ability to maintain their sovereignty and control their borders..$^{512}$

The United States also required the Five Tribes to form a single territorial government, headed by an elected council of Native delegates. Native Americans understood this as a threat to their individual tribal identities and opposed "territorialization" or statehood adamantly. Delegates were selected, a constitution was drawn up (the "Okmulgee constitution"), and the council met off-and-on throughout the 1870 s, but the constitution and subsequent versions were

${ }^{511}$ Kidwell, The Choctaws of Oklahoma, 80-81; Bean, "Who Defines a Nation?," 115, 117-118; Debo, Rise and Fall of the Choctaw Republic, 88-90; Fay Yarbrough, “'Dis Land Which Jines Dat of Ole Master's': The Meaning of Citizenship for the Choctaw Freedpeople" in Civil War Wests: Testing the Limits of the United States, edited by Adam Arenson and Andrew R. Graybill (Oakland: University of California Press, 2015), 232. Fay Yarbrough's essay offers an excellent introduction to the issues facing Choctaw freedpeople in the Reconstruction eras.

${ }^{512}$ Bean, "Who Defines a Nation?," 120; Kidwell, The Choctaws of Oklahoma, 85; Edwin C. McReynolds, Oklahoma: A History of the Sooner State (1954, repr., Norman: University of Oklahoma Press, 1964), 270-277. 
never ratified. It was clear Native Americans had little intention of forming a territorial government, and by drawing out the affair, they managed to kill it off. ${ }^{513}$

The Five Tribes also faced the threat of allotment. The United States wanted Native Americans to parcel out their land (allot it) to individuals and families and thus end the practice of tribal land claims, believing allotment would facilitate assimilation into American society. Despite the United States' agenda, the Five Tribes neutralized the threat of allotment in the 1866 treaties. While the treaties contained an allotment provision, it would only occur if tribal governments "through their respective legislative councils, agree to the survey and division of their land." Since the Five Tribes did not want to see tribal lands parceled off, the clause effectively prevented allotment. Still, as with the United States' request for a territorial government, it was clear the United States' long-term goal was the dissolution of tribal governments. ${ }^{514}$

Collectively, the 1866 Reconstruction Treaties between the United States and the Five Tribes marked an important moment of transition. The Civil War in Indian Territory constituted an Indian Civil War, waged over issues of acculturation, slavery, and the bitter politics of removal. And certainly, issues of acculturation and factionalism continued after the war-with factionalism on full display during treaty negotiations in Washington. Among the Creek and Cherokee tribes especially, factionalism continued to plague national affairs and even flared into violence occasionally in the postbellum era.

Yet at the 1866 treaties attest, in the wake of the Civil War, a host of new challenges to Native American sovereignty loomed on the horizon. The treaties secured railroad rights which

${ }^{513}$ Bean, "Who Defines a Nation?," 122-123.

${ }^{514}$ Kidwell, The Choctaws of Oklahoma, 81; Janet A. McDowell, The Dispossession of the American Indian, 1887-1934 (Bloomington: Indiana University Press, 1991), 1-2. 
would bring white settlers and the outside world flooding into Indian Territory over the next several decades. And while the Five Tribes largely managed to dodge the United States' attempts to impose territorial government or allotment, it was clear the United States would continue to pursue these policies in the future.

And over time, the United States succeeded in implementing their designs of abolishing tribal governments, tribal lands, and tribal sovereignty. In the decades following the Civil War, the United States defeated the Plains Indian tribes and forced many of them-including the Apache, Arapaho, Cheyenne, Comanche, and Kiowa—onto reservations in western Indian Territory, the land purchased from the Five Tribes in 1866. In the 1870s, the United States ceased treating Native Americans as sovereign states, no longer negotiating treaties but rather deciding Indian policy in the halls of Congress. In the 1880s, allotment came to Indian Territory, and the western Indian reservations were carved into parcels and opened to white settlement. In 1890, the western half of Indian Territory became Oklahoma Territory and the "Twin Territories" uneasily coexisted. In 1897, the Dawes Commission finally forced the Five Tribes to accept allotment as well. Over the next few years, membership of the tribes was determined (known as the Dawes Rolls) and land parceled out. The Five Tribes—-the nations, their governments, their sovereignty—dismantled. In 1907, Oklahoma became the forty-sixth state to enter the Union.

Reflecting on the dissolution of Native governments in his old age, Creek George Washington Grayson, who had once fought as a young lieutenant under Stand Watie in the Civil War, lamented:

"Here we, a people who had been a self-governing people for hundreds and possibly a thousand years, who had a government and administer its affairs ages before such an entity as the Untied States was ever dreamed of, are asked and admonished that we must 
give up all idea of local government, change our system of land holding to that which we confidently believed had pauperized thousands of white people - all for why; not because we had violated any treaties with the United States which guaranteed in solemn terms our undisturbed possession of these; not because of any respectable number of Indians were clamoring for a change of conditions; not because any non-enforcement of law prevailed to a greater extent in Indian territory than elsewhere; but simply because regardless of the plain dictates of justice and a christian conscious, the ruthless white man demanded it." ${ }^{515}$

Ultimately, the American Civil War in Indian Territory unleashed profound waves of bloodshed and destruction that hinged on Native American issues of acculturation, slavery, and removal. Pulled into fraudulent Confederate alliances that reflected the views of only wealthy, privileged Native Americans, four years of Civil War ravaged the landscape and its people, inflicting untold suffering and death. Weakened by war and riven with internal strife, the Five Tribes of Indian Territory struggled at the negotiating table in 1866. The railroads, land runs, allotment, and final dissolution of their governments lay in the future, but the roots of Native dispossession resided in the Indian Civil War.

515 Grayson, A Creek Warrior for the Confederacy, 163-164. 


\section{Bibliography}

\section{$\underline{\text { Abbreviations }}$}

\begin{tabular}{|c|c|}
\hline $\mathrm{AHC}$ & Arkansas History Commission \\
\hline BCAS & Butler Center for Arkansas Studies \\
\hline GI & Thomas Gilcrease Institute of American History and Art \\
\hline HCHRC & Hill College Historical Research Center \\
\hline KHS & Kansas Historical Society \\
\hline NEHGS & New England Historic Genealogical Society \\
\hline $\mathrm{OHC}$ & Ohio History Connection Library \& Archives \\
\hline OHS & Oklahoma Historical Society \\
\hline OIA & Office of Indian Affairs, National Archives \\
\hline $\mathrm{OU}$ & $\begin{array}{l}\text { University of Oklahoma } \\
\text { WHC Western History Collection } \\
\text { IPP Indian Pioneer Papers }\end{array}$ \\
\hline PHS & $\begin{array}{l}\text { Presbyterian Historical Society } \\
\text { AIC American Indian Correspondence }\end{array}$ \\
\hline RBIA & Records of Bureau of Indian Affairs, National Archives [Record Group 75] \\
\hline WHC & Wisconsin Historical Society \\
\hline
\end{tabular}

\section{Newspapers}

Ashtabula Weekly Telegraph [Ashtabula, OH]

Big Blue Union [Marysville, KS]

Cherokee Tomahawk [Fort Gibson, Cherokee Nation]

Cleveland Morning Leader [Cleveland, $\mathrm{OH}]$

Dallas Herald [Dallas, TX] 
Emporia News [Emporia, KS]

Fort Scott Bulletin [Fort Scott, KS]

Jeffersonian Democrat [Chardon, $\mathrm{OH}]$

Lawrence Republican [Lawrence, KS]

New York Times [New York City, NY]

Northern Standard / Standard [Clarksville, TX]

Smoky Hill and Republican Union [Junction City, KS]

Soldiers Letter. Second Colorado Cavalry [Kansas City, MO]

Van Buren Press [Van Buren, AR]

Western Reserve Chronicle [Warren, $\mathrm{OH}]$

White Cloud Kansas Chief [White Cloud, KS]

\section{Manuscript Collections}

Arkansas

Arkansas History Commission, Little Rock, AR

Asa Morgan Collection [26 ${ }^{\text {th }}$ Arkansas Infantry]

Butler Center for Arkansas Studies, Little Rock, AR

C.H. Pidcocke Civil War Letter [30 ${ }^{\text {th }}$ Texas Cavalry]

John R. Graton Letters [ $1^{\text {st }}$ Kansas Colored Infantry]

Joseph G. Farr Civil War Papers [24 ${ }^{\text {th }}$ Arkansas Infantry]

Paul Dolle Civil War Collection

Hermann Schlueter Diary [ $9^{\text {th }}$ Wisconsin Infantry; digitized] 


\section{District of Columbia}

National Archives, Washington, D.C.

Record Group 48: Records of the Office of the Secretary of the Interior

Letters Sent, Indian Division of the Office of the Secretary of the Interior

Record Group 75: Records of the Bureau of Indian Affairs

Letters Received by the Office of Indian Affairs, 1824-1880

Report Books, Office of Indian Affairs, 1838-1881

Record Group 109: War Department Collection of Confederate Records, 1826-1927

Records of the Department of Texas \& the Trans-Mississippi

Letters Sent, District of Indian Territory, May 1865

Kansas

Kansas Historical Society, Topeka, KS

John R. Graton Papers [1 ${ }^{\text {st }}$ Kansas Colored Infantry]

Massachusetts

New England Historic Genealogical Society, Boston, MO

Capt. Ethan Earle Account Book [ $1^{\text {st }}$ Kansas Colored Infantry]

\section{Missouri}

Missouri Historical Society, St. Louis, MO

Civil War Collection, 1860-1977 [digitized]

\section{Ohio}

Ohio History Connection Archives \& Library, Columbus, Ohio

Albert Houghton Papers [2 $2^{\text {nd }}$ Ohio Cavalry] 


\section{Oklahoma}

Helmerich Center for American Research, Thomas Gilcrease Institute of American History and Art, Tulsa, OK

James Greene Walker Collection

John Drew Papers [ $2^{\text {nd }}$ Cherokee Mounted Rifles]

Peter Pitchlynn Papers

Samuel Austin Worcester Papers

Hannah Hicks Diary

Samuel Bell Maxey Papers

Oklahoma Historical Society, Oklahoma City, OK

Dallas W. Bowman Collection [ $1^{\text {st }}$ Choctaw \& Chickasaw Mounted Rifles $]$

Reverend Henry F. Buckner Collection

Stand Watie Collection

Western History Collections, University of Oklahoma, Norman, OK

Indian Pioneer Papers

Peter Pitchlynn Papers

Stephen Foreman Papers

\section{Pennsylvania}

Presbyterian Historical Society, Philadelphia, PA

American Indian Correspondence

Texas

Hill College Historical Research Center, Hillsboro, TX

$5^{\text {th }}$ Texas Partisan Rangers File 
David Elhannon Dumas Remembrance

$6^{\text {th }}$ Texas Cavalry File

Cyrus, John, and Sam Love Letters

John Miller Diary

$9^{\text {th }}$ Texas Cavalry File

Benjamin Rush Vines Letter

Warren Coffman Letter

$20^{\text {th }}$ Texas Cavalry File

R. McDermott Letters [29 $9^{\text {th }}$ Texas Cavalry]

University of North Texas, Denton, TX

Private Collection of Jim McDermott [digitized]

University of Texas-Austin, Austin, TX

George L. Griscom Papers [9 $9^{\text {th }}$ Texas Cavalry]

\section{Wisconsin}

Wisconsin Historical Society, Madison, WI

Quiner Scrapbooks [digitized]

\section{Government Publications}

The Cherokee Question: Report of the Commissioner of Indian Affairs to the President of the

United States, June 15, 1866. Washington, D.C.: Government Printing Office, 1866. Reports of the Commissioner of Indian Affairs. 1861-1865. Washington, D.C.: Government Printing Office, 1861-1865. 
The War of the Rebellion: A Compilation of the Official Records of the Union and Confederate Armies. Edited by Robert N. Scott. Series I. 53 vols. Washington D.C.: Government Printing Office, 1885.

\section{Printed Primary Sources}

Anderson, C.T. "Campaigning in Southern Arkansas: A Memoir by C.T. Anderson.” Edited by Roman J. Zorn. Arkansas Historical Quarterly 8, no. 3 (Autumn, 1948): 240-244.

Avera, William Franklin, "Extracts from the Memoirs of William Franklin Avera." Edited by Henry Cathey. Arkansas Historical Quarterly 22, no. 2 (Summer, 1963): 99-116.

Averell, William Woods. Ten Years in the Saddle: The Memoir of William Woods Averell. Edited by Edward K. Eckert and Nicholas J. Amato. San Rafael, CA: Presidio Press, 1978.

Baker, Julie P. and T. Lindsay, editors. The WPA Oklahoma Slave Narratives. Norman: University of Oklahoma Press, 1996.

Bates, James C. A Texas Cavalry Officer's Civil War: The Diary and Letters of James C. Bates. Edited by Richard Lowe. Baton Rouge: Louisiana State University Press, 1999. [9 $9^{\text {th }}$ Texas Cavalry]

Blunt, James. "General Blunt's Account of His Civil War Experiences." Kansas Historical Quarterly 1, no. 3 (May, 1932): 211-265.

Britton, Wiley. Memoirs of the Rebellion on the Border, 1863. 1882. Reprint. Lincoln: University of Nebraska Press, 1993. [ $6^{\text {th }}$ Kansas Cavalry]

Cater, Douglas John. As It Was: Reminiscences of a Soldier of the Third Texas Cavalry and the Nineteenth Louisiana Infantry. Austin, TX: State House Press, 1990. [3 ${ }^{\text {rd }}$ Texas Cavalry] 
Cravens, William Murphy. "Prairie Ann and Poison Spring: A Perspective.” Edited by Joseph Frankovic, Jeremy Lynch, Julie Northrip, and Sam Trisler. Journal of the Fort Smith Historical Society 31, no. 1 (April, 2007): 35-44.

Dale, Edward Everett and Gaston Litton, editors. Cherokee Cavaliers: Forty Years of Cherokee History as Told in the Correspondence of the Ridge-Watie-Boudinot Family. 1939. Reprint, Norman: University of Oklahoma Press, 1995.

Doubleday, Charles W. Reminiscences of the Filibuster War in Nicaragua. New York: G.P. Putnam's Sons, 1886.

Edwards, John. "My Escape from the South in 1861." Chronicles of Oklahoma 43, no. 1 (1965): 58-89.

Gardner, Theodore. “The First Kansas Battery: A Historical Sketch, with Personal Remembrances of Army Life, 1861-'65." Collections of the Kansas State Historical Society, 1915-1918. Vol. 14. Edited by William Connelley. Topeka: Kansas State Printing Plant, 1918. [1 $1^{\text {st }}$ Kansas Battery]

Gause, Isaac. Four Years with Five Armies: Army of the Frontier, Army of the Potomac, Army of the Missouri, Army of the Ohio, Army of the Shenandoah. New York: Neale Publishing, 1908. [2 $2^{\text {nd }}$ Ohio Cavalry]

General Catalogue of Lane Theological Seminary 1828-1881. Cincinnati, OH: Elm Street Printing Co., 1881.

Grayson, George Washington. A Creek Warrior for the Confederacy: The Autobiography of Chief G.W. Grayson. Edited by W. David Baird. Norman: University of Oklahoma Press, 1988. [2 $2^{\text {nd }}$ Creek Regiment] 
Griscom, George L. Fightin' with Ross' Texas Cavalry Brigade, C.S.A.: The Diary of George L. Griscom, Adjutant, $9^{\text {th }}$ Texas Cavalry Regiment. Edited by Homer L. Kerr. Hillsboro, TX: Hillsboro Jr. College Press, 1976. [9 $9^{\text {th }}$ Texas Cavalry]

Haas, Jacob. This Day We Marched Again: A Union Soldier's Account of War in Arkansas and the Trans-Mississippi, the Civil War Diary of Jcaob Haas. Edited by Mark K. Christ. Little Rock, AR: Butler Center for Arkansas Studies, 2014. [ $9^{\text {th }}$ Wisconsin Infantry] Jackman, Sidney Drake. Behind Enemy Lines: The Memoirs and Writings of Brigadier General Sidney Drake Jackman. Edited by Richard L. Norton. Springfield, MO: Oak Hills Publishing, 1997.

Johansson, M. Jane, editor. Albert C. Ellithorpe, the First Indian Home Guard, and the Civil War on the Trans-Mississippi Frontier. Baton Rouge: Louisiana State University Press, 2016. $\left[1^{\text {st }}\right.$ Indian Home Guard $]$

Kitts, John Howard. "The Civil War Diary of John Howard Kitts." Collections of the Kansas State Historical Society, 1915-1918. Vol. 14. Edited by William Connelley. Topeka: Kansas State Printing Plant, 1918. [11 ${ }^{\text {th }}$ Kansas Infantry]

Lincoln, Abraham. The Collected Works of Abraham Lincoln. 8 vols. Edited by Roy P. Basler. New Brunswick, NJ: Rutgers University Press, 1953.

Lothrop, Charles D. A History of the First Regiment Iowa Cavalry. Lyons, IA: Beers \& Eaton, 1890. [1 $1^{\text {st }}$ Iowa Cavalry $]$

McCall, George A. Letters from the Frontiers. Philadelphia, PA: J.B. Lippincott \& Co., 1868. McMahon, Robert T. Reluctant Cannoneer: The Diary of Robert T. McMahon of the TwentyFifth Independent Ohio Light Artillery. Edited by Michael Banasik. Iowa City, IA: Camp Pope Publishing, 2000. [25 ${ }^{\text {th }}$ Ohio Independent Light Artillery] 
Ross, John. The Papers of Chief John Ross. 2 vols. Edited by Gary E. Moulton. Norman: University of Oklahoma Press, 1985.

Smith, William R. The History and Debates of the Convention of the People of Alabama. Atlanta, GA: Wood, Hanleiter, Rice \& Co., 1861.

Sparks, A.W. The War Between the States, As I Saw It: Reminiscent, Historical and Personal. Tyler, TX: Lee \& Burnett, 1901. [9 $9^{\text {th }}$ Texas Cavalry]

Strong, Henry A. "A Rough Introduction to This Sunny Land”: The Civil War Diary of Private Henry A. Strong, Co. K, Twelfth Kansas Infantry. Edited by Tom Wing. Little Rock: Butler Center for Arkansas Studies, 2006. [12 ${ }^{\text {th }}$ Kansas Infantry]

Tenney, Luman Harris. War Diary of Luman Harris Tenney. Cleveland, OH: Evangelical Publishing House, 1914. [2 $2^{\text {nd }}$ Ohio Infantry]

Tunnard, W.H. A Southern Record: The History of the Third Regiment Louisiana History. Baton Rouge, LA, 1866. [3 ${ }^{\text {rd }}$ Louisiana Infantry]

Warner, Anna. A Servant of the King: Incidents in the Life of the Rev. George Ainslie. New York: John Ireland, 1889.

Whipple, Henry Chester. Recollections of the War of the Rebellion. Edited by Alberta R. Adamson, Robert I. Girardi, and Roger E. Bohn. Wheaton, IL: Wheaton History Center, 1996. [2 $2^{\text {nd }}$ Ohio Cavalry]

Yeary, Mamie, editor. Reminiscences of the Boys in Gray. 2 vols. Dallas, TX: Smith \& Lamar, 1912.

Zimmer, Michael. Michael Zimmer's Diary: Deutsches Tagebuch aus dem Amerikanischen Bürgerkrieg. Edited by Jürgen Macha and Andrea Wolf. Frankfurt, Germany: Peter Lang GmbH, 2001. [9 ${ }^{\text {th }}$ Wisconsin Infantry] 


\section{$\underline{\text { Secondary Sources }}$}

Abel, Annie Heloise. The American Indian and the End of the Confederacy, 1863-1866. 1925.

Reprint. Lincoln: University of Nebraska Press, 1993.

Abel, Annie Heloise. The American Indian in the Civil War, 1862-1865. 1919. Reprint. Lincoln:

University of Nebraska Press, 1992.

Abel, Annie Heloise. The American Indian as Slaveholder and Secessionist. 1915. Reprint, Lincoln: University of Nebraska Press, 1992.

Anderson, William L., ed. Cherokee Removal: Before and After. Athens: University of Georgia Press, 1991.

Arenson, Adam and Andrew R. Graybill, editors. Civil War Wests: Testing the Limits of the United States. Oakland: University of California Press, 2015.

Arey, Frank. "“The Place is Well Fortified': Massard Prairie and the Confederate Attack on Fort Smith, July 27 and 31, 1864.” Journal of the Fort Smith Historical Society 27, no. 1 (April, 2003): 3-9.

Ashcroft, Allan C. “Confederate Indian Troop Conditions in 1864.” Chronicles of Oklahoma 41, no. 4 (Winter, 1964), 442-449.

Bailey, Anne J. “Was There a Massacre at Poison Spring?” Military History of the Southwest 20, no. 2 (Fall, 1990): 157-168.

Bailey, Anne J. and Daniel E. Sutherland, editors. Civil War Arkansas: Beyond Battles and Leaders. Fayetteville: University of Arkansas Press, 2000.

Baird, W. David. Peter Pitchlynn: Chief of the Choctaws. Norman: University of Oklahoma Press, 1972.

Barr, Alywn. Polignac's Texas Brigade. College Station: Texas A\&M University Press, 1998. 
Bearss, Edwin C. Steele's Retreat from Camden \& the Battle of Jenkins Ferry. 1966. Reprint. Little Rock, AR: Eagle Press, 1990.

Bearss, Edwin C. “General Cooper's CSA Indians Threaten Fort Smith.” Arkansas Historical Quarterly 26, no. 3 (Autumn, 1967): 257-284.

Beilein, Jr., Joseph M. and Matthew C. Hulbert, eds. The Civil War Guerrilla: Unfolding the Black Flag in History, Memory, and Myth. Lexington: University Press of Kentucky, 2015.

Belich, James. Replenishing the Earth: The Settler Revolution and the Rise of the Anglo-World, 1783-1939. New York: Oxford University Press, 2009.

Braund, Kathryn E. Holland. Deerskins and Duffels: The Creek Trade with Anglo-America, 1685-1815. $2^{\text {nd }}$ edition. Lincoln: University of Nebraska Press, 2008.

Britton, Wiley. The Union Indian Brigade: The Five Civilized Nations in the Civil War. Kansas City, MO: Franklin Hudson Publishing, 1922.

Brown, Thomas Elton. "Seminole Indian Agents, 1842-1874.” Chronicles of Oklahoma 51, no. 1 (1973): 59-83.

Brown, Walter Lee. A Life of Albert Pike. Fayetteville: University of Arkansas Press, 1997.

Brownlee, Richard. Gray Ghosts of the Confederacy: Guerrilla Warfare in the West, 1861-1865. 1958. Reprint. Baton Rouge: Louisiana State University Press, 1985.

Bruce, Michael L. “'Our Best Men Are Fast Leaving Us': The Life and Times of Robert M. Jones," Chronicles of Oklahoma 66, no. 3 (1988): 294-305.

Burk, Jerry L. "Oklahoma Seminole Indians: Origin, History, and Pan-Indianism," Chronicles of Oklahoma 51, no. 2 (1973): 211-223. 
Cantrell, Mark Lea and Mac Harris, editors. Kepis and Turkey Calls: An Anthology of the War between the States in Indian Territory. Oklahoma City, OK: Western Heritage Books, 1982.

Carter, Edward L. “The Seminole Indians after Leaving Florida, 1855-1860.” Chronicles of Oklahoma 55, no. 4 (1977): 433-453.

Castel, Albert. Civil War Kansas: Reaping the Whirlwind. 1958. Reprint. Lawrence: University Press of Kansas, 1997.

Chapman, George. Chief William McIntosh: A Man of Two Worlds. Atlanta, GA: Cherokee Publishing, 1988.

Christ, Mark K., ed. “All Cut to Pieces and Gone to Hell”: The Civil War, Race Relations, and the Battle of Poison Spring. Little Rock, AR: August House, 2003.

Clampitt, Bradley R, ed. The Civil War and Reconstruction in Indian Territory. Lincoln: University of Nebraska Press, 2015.

Clifford, Roy A. "The Indian Regiments in the Battle of Pea Ridge." Chronicles of Oklahoma 25, no. 4 (Winter, 1947-1948), 214-322.

Coleman, Michael C. Presbyterian Missionary Attitudes toward American Indians, 1837-1893. Jackson: University of Mississippi Press, 1985.

Collins, Robert. General James G. Blunt: Tarnished Glory. Gretna, LA: Pelican Publishing Co., 2005.

Collins, Robert. Jim Lane: Scoundrel, Statesmen, Kansan. Gretna, LA: Pelican Publishing Co., 2007.

Confer, Clarissa. The Cherokee Nation in the Civil War. Norman: University of Oklahoma Press, 2007. 
Cowsert, Zachery. "Political Machinations, Texan Intimidations: The Choctaw Nation Enters the Civil War," Chronicles of Oklahoma 94, no. 2 (Summer, 2016): 186-207.

Cox, Dale. The Battle of Massard Prairie: The 1864 Confederate Attacks on Fort Smith, Arkansas. Bascom, FL: William Cox, 2008.

Cox, Steve. "The Action of Massard Prairie." Journal of the Fort Smith Historical Society 4, no. 1 (April, 1980): 11-13.

Current, Richard Nelson. Lincoln's Loyalists: Union Soldiers from the Confederacy. Boston, MA: Northeastern University Press, 1992.

Dale, Edward Everett. "The Cherokees in the Confederacy." Journal of Southern History 13, no. 2 (May, 1947), 159-185.

Darling, Ernest F. “Lincoln's Message to Indian Territory.” Chronicles of Oklahoma 63, no. 2 (1985): 186-191.

Debo, Angie. The Rise and Fall of the Choctaw Republic. 1934. Reprint, Norman: University of Oklahoma Press, 1961.

Debo, Angie. The Road to Disappearance: A History of the Creek Indians. 1941. Reprint, Norman: University of Oklahoma Press, 1987.

Doran, Michael F. "Population Statistics of Nineteenth-Century Indian Territory." Chronicles of Oklahoma 53, no. 4 (1975): 492-516.

Doran, Michael F. "Negro Slaves of the Five Civilized Tribes.” Annals of the Association of American Geographers 68:3 (Sept., 1979), 335-350.

Drake, Brian Allen. The Blue, The Gray, and the Green: Toward an Environmental History of the Civil War. Athens: University of Georgia Press, 2015. 
Ehle, John. Trail of Tears: The Rise and Fall of the Cherokee Nation. New York: Anchor Press, 1988.

Emory, Thomas M. The Confederacy as a Revolutionary Experience. 1971. Reprint. Columbia: University of South Carolina Press, 1991.

Escott, Paul D. After Secession: Jefferson Davis and the Failure of Confederate Nationalism. Baton Rouge: Louisiana State University Press, 1977.

Faulk, Odie B., Kenny A. Franks, and Paul F. Lambert, editors. Early Military Forts and Posts in Oklahoma. Oklahoma City: Oklahoma Historical Society, 1978.

Fischer, LeRoy H., editor. The Civil War Era in Indian Territory. Los Angeles, CA: Lorrin L. Morrison, 1974.

Fischer, LeRoy H. and William L. McMurry. "Confederate Refugees from Indian Territory." Chronicles of Oklahoma. 57, no. 4 (1979): 451-462.

Foreman, Grant. A History of Oklahoma. 1942. Reprint, Norman: University of Oklahoma Press, 1945.

Forsyth, Michael J. The Camden Expedition of 1864 and the Opportunity Lost by the Confederacy to Change the Civil War. Jefferson, NC: McFarland, 2003.

Frank, Andrew K. Creeks and Southerners: Biculturalism on the Early American Frontier. Lincoln: University of Nebraska Press, 2005.

Franks, Kenny A. Stand Watie and the Agony of the Cherokee Nation. Memphis: Memphis State University Press, 1979.

Freehling, William W. The South vs. The South: How Anti-Confederate Southerners Shaped the Course of the Civil War. New York: Oxford University Press, 2001. 
Gaines, W. Craig. The Confederate Cherokees: John Drew's Regiment of Mounted Rifles. Baton Rouge: Louisiana State University Press, 1989.

Glatthaar, Joseph T. Forged in Battle: The Civil War Alliance of Black Soldiers and White Officers. Baton Rouge: Louisiana State University Press, 1990.

Grear, Charles D. "Red and White Fighting the Blue: Relations between Texans and Confederate Indians." In The Seventh Star of the Confederacy: Texas during the Civil War. Edited by Kenneth W. Howell. Denton: University of North Texas Press, 2009.

Hahn, Steven. Political Worlds of Slavery and Freedom. Cambridge: Harvard University Press, 2009.

Haimerl, David. Clarkson's Battalion, C.S.A.: A Brief History and Roster. Independence, MO: Two Trails Publishing, 2005.

Horton, Louise. Samuel Bell Maxey: A Biography. Austin: University of Texas Press, 1974.

Jewett, Clayton E. Texas in the Confederacy: An Experiment in Nation Building. Columbia: University of Missouri Press, 2002.

Johnson, Ludwell H. Red River Campaign: Politics \& Cotton in the Civil War. 1958. Reprint. Kent, OH: Kent State University Press, 1996.

Johnston, Carolyn Ross. Cherokee Women in Crisis: Trail of Tears, Civil War, and Allotment, 1838-1907. Tuscaloosa: University of Alabama Press, 2003.

Keller, Christian B. Chancellorsville and the Germans: Nativism, Ethnicity, and Civil War Memory. New York: Fordham University Press, 2007.

Kidwell, Clara Sue. The Choctaws in Oklahoma: From Tribe to Nation, 1855-1970. Norman: University of Oklahoma Press, 2007. 
Lancaster, Jane. Removal Aftershock: The Seminole's Struggles to Survive in the West, 18361866. Knoxville: University of Tennessee Press, 1994.

Lewis, Anna. "Camp Napoleon.” Chronicles of Oklahoma 9, no. 4 (December, 1931): 359-364.

Littlefield, Jr., Daniel F. African and Seminoles: From Removal to Emancipation. 1977. Reprint, Jackson: University Press of Mississippi, 2001.

Lull, Robert W. James M. Williams, Leader of the $1^{\text {st }}$ Kansas Colored Volunteer Infantry and the $8^{\text {th }}$ U.S. Cavalry. Denton: University of North Texas Press, 2013.

Mahon, John K. History of the Second Seminole War, 1835-1842. 1967. Reprint, Gainesville: University of Florida Press, 1985.

Manning, Chandra. Troubled Refuge: Struggling for Freedom in the Civil War. New York: Alfred A. Knopf, 2016.

Martin, Joel W. Sacred Revolt: The Muskogee's Struggle for a New World. Boston, MA: Beacon Press, 1991.

Matthews, Matt and Kip Lundberg. "Shot All to Pieces: The Battle of Lone Jack, Missouri, August 16, 1862." North and South 7, no. 1 (January, 2004): 58-74.

Massey, Mary Elizabeth. Refugee Life in the Confederacy. Baton Rouge: Louisiana State University Press, 1964.

McBride, Lela J. Opothleyaholo and the Loyal Muskogee: Their Flight to Kansas in the Civil War. Jefferson, NC: McFarland, 2000.

McCurry, Stephanie. Confederate Reckoning: Power and Politics in the Civil War South. Cambridge, MA: Harvard University Press, 2010.

McDonough, James L. Schofield: Union General in the Civil War and Reconstruction. Tallahassee: Florida State University Press, 1972. 
McDowell, Janet A. The Dispossession of the American Indian, 1887-1934. Bloomington: Indiana University Press, 1991.

McKnight, Brian D. and Barton A. Myers, eds. The Guerrilla Hunters: Irregular Conflicts during the Civil War. Baton Rouge: Louisiana State University Press, 2007.

McLoughlin, William G. After the Trail of Tears: The Cherokees Struggle for Sovereignty, 18391880. Chapel Hill: University of North Carolina Press, 1993.

McMahon, John K. History of the Second Seminole War, 1835-1842. 1967. Reprint. Gainesville: University Presses of Florida, 1985.

McReynolds, Edwin C. Oklahoma: A History of the Sooner State. 1954. Reprint. Norman: University of Oklahoma Press, 1964.

Minges, Patrick N. Slavery in the Cherokee Nation: The Keetoowah Society and the Defining of a People, 1855-1867. New York: Routledge, 2003.

Neal, Diane and Thomas W. Kremm. Lion of the South: General Thomas C. Hindman. Macon, GA: Mercer University Press, 1993.

Nichols, David. Lincoln and the Indians: Civil War Policy and Politics. Columbia: University of Missouri Press, 1978.

Norris, L. David, James G. Milligan, and Odie B. Faulk. William H. Emory: Soldier-Scientist. Tucson: University of Arizona Press, 1998.

Oklahoma Climatological Survey. "State Records."

Parins, James W. John Rollin Ridge: His Life \& Works. Lincoln: University of Nebraska Press, 2004.

Perdue, Theda. Mixed Blood Indians: Racial Construction in the Early South. Athens: University of Georgia Press, 2003. 
Piston, William Garrett and Richard W. Hatcher III. Wilson's Creek: The Second Battle of the Civil War and the Men Who Fought It. Chapel Hill: University of North Carolina Press, 2000.

Quigley, Paul. Shifting Grounds: Nationalism and the American South, 1848-1865. New York: Oxford University Press, 2012.

Rampp, Lary C. and Donald L. The Civil War in the Indian Territory. Austin, TX: Presidial Press, 1975.

Rein, Chris. "The U.S. Army, Indian Agency, and the Path to Assimilation." Kansas History: A Journal of the Central Plains 36 (Spring, 2013): 2-21.

Reynolds, Edwin C. The Seminoles. Norman: University of Oklahoma Press, 1957.

Romansky, Thaddeus Michael. "Disunion in the Ranks: Soldiers, Citizenship, and Mutiny in the Union Army.” PhD diss., Texas A\&M University, 2015.

Saunt, Claudio. A New Order of Things: Property, Power, and the Transformation of the Creek Indians, 1733-1816. New York: Cambridge University Press, 1999.

Scharff, Virginia, ed. Empire and Liberty: The Civil War and the West. Oakland: University of California Press, 2015.

Shea, William L. Fields of Blood: The Prairie Grove Campaign. Chapel Hill: University of North Carolina Press, 2009.

Shea, William L. War in the West: Pea Ridge and Prairie Grove. Fort Worth: Ryan Place Publishers, 1996.

Shea, William L. and Ear J. Hess. Pea Ridge: Civil War Campaign in the West. Chapel Hill: University of North Carolina Press, 1992. 
Silkenat, David. Driven from Home: North Carolina's Civil War Refugee Crisis. Athens: University of Georgia Press, 2016.

Smith, Troy. "Nations Colliding: The Civil War Comes to Indian Territory." Civil War History 59: 3 (Sept., 2013), 279-319.

Spurgeon, Ian M. Soldiers in the Army of Freedom: The $1^{\text {st }}$ Kansas Colored, the Civil War's First African American Combat Unit. Norman: University of Oklahoma Press, 2014.

Stith, Matthew. Extreme Civil War: Guerrilla Warfare, Environment, and Race on the TransMississippi Frontier. Baton Rouge: Louisiana State University Press, 2016.

Sutherland, Daniel E. A Savage Conflict: The Decisive Role of Guerrillas in the American Civil War. Chapel Hill: University of North Carolina Press, 2013.

Taylor, Amy Murrell. Embattled Freedom: Journeys through the Civil War's Slave Refugee Camps. Chapel Hill: University of North Carolina Press, 2018.

Thoburn, Joseph B. A Standard History of Oklahoma. Chicago, IL: American Historical Society, 1916.

Tucker, Richard P. and Edmund Russell. Natural Enemy, Natural Ally: Toward an Environmental History of War. Corvallis: Oregon State University Press, 2004.

Urwin, Gregory J.W., editor. Black Flag Over Dixie: Racial Atrocities and Reprisals in the Civil War. Carbondale: Southern Illinois University Press, 2005.

Warde, Mary Jane. When the Wolf Came: The Civil War and the Indian Territory. Fayetteville: University of Arkansas Press, 2013.

Warner, Ezra. Generals in Gray: Lives of Confederate Commanders. 1959. Reprint. Baton Rouge: Louisiana State University Press, 1994. 
Waugh, John C. Sam Bell Maxey and the Confederate Indians. Abilene, TX: McWhiney Foundation Press, 1998.

Weddle, Robert S. Plow-Horse Cavalry: The Caney Creek Boys of the Thirty-Fourth Texas. Austin, TX: Madrona Press, 1974.

White, Richard. The Roots of Dependency: Subsistence, Environment, and Social Change among the Choctaws, Pawnees, and Navajos. Lincoln: University of Nebraska Press, 1983.

Wilkins, Thurman. Cherokee Tragedy: The Ridge Family and the Decimation of a People. Norman: University of Oklahoma Press, 1986.

Winters, Richard, Gerald E. Galloway Jr., William J, Reynolds, and David W. Rhyme. Battling the Elements: Weather and Terrain in the Conduct of War. Baltimore: Johns Hopkins University Press, 1998.

Wood, Larry. The Two Civil War Battles of Newtonia. 2010. Reprint. Charleston, SC: History Press, 2013.

Woodward, Grace Steele. The Cherokees. 1963. Reprint, Norman: University of Oklahoma Press, 1988.

Wooster, Ralph A. Lone Star Regiments in Gray. Fort Worth, TX: Eakin Press, 2002.

Zellar, Gary. African Creeks: Estelvste and the Creek Nation. Norman: University of Oklahoma Press, 2007. 